$D R \# 0459-6$ DOEIPC/70770-T10 (DE87013912)

\title{
Fundamental studies of the mechanisms of slag deposit formation: Final report
}

Austin, L.G.; Benson, S.; Rabinovich, A.; Tangsathitkulchai, M.; Schobert H.H.

Jul 1987

Pennsylvania State Univ., University Park (USA). Coll. of Earth and Mineral Sciences

Reproduced and Distributed by:

U.S. DEPARTMENT OF ENERGY

Office of Scientific and Technical Information

P.O. Box 62

Oak Ridge, TN 37831

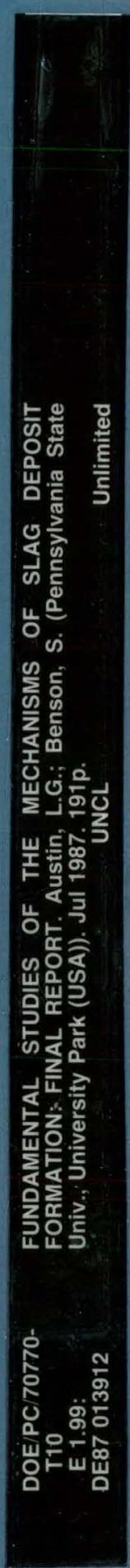




\section{DISCLAIMER}

This report was prepared as an account of work sponsored by an agency of the United States Government. Neither the United States Government nor any agency Thereof, nor any of their employees, makes any warranty, express or implied, or assumes any legal liability or responsibility for the accuracy, completeness, or usefulness of any information, apparatus, product, or process disclosed, or represents that its use would not infringe privately owned rights. Reference herein to any specific commercial product, process, or service by trade name, trademark, manufacturer, or otherwise does not necessarily constitute or imply its endorsement, recommendation, or favoring by the United States Government or any agency thereof. The views and opinions of authors expressed herein do not necessarily state or reflect those of the United States Government or any agency thereof. 


\section{DISCLAIMER}

Portions of this document may be illegible in electronic image products. Images are produced from the best available original document. 


\section{DISCLAIMER}

This report was prepared as an account of work sponsored by an agency of the United States Government. Neither the United States Government nor any agency thereof, nor any of their employees, makes any warranty, express or implied, or assumes any legal liability or responsibility for the accuracy, completeness, or usefulness of any information, apparatus, product, or process disclosed, or represents that its use would not infringe privately owned rights. Reference herein to any specific commercial product, process, or service by trade name, trademark, manufacturer, or otherwise does not necessarily constitute or imply its endorsement, recommendation, or favoring by the United States Government or any agency thereof. The views and opinions of authors expressed herein do not necessarily state or reflect those of the United States Government or any agency thereof.

This report has been reproduced directly from the best available copy.

Available from the National Technical Information Service, U. S. Department of Commerce, Springfield, Virginia 22161.

Price: Printed Copy A09

Microfiche A01

Codes are used for pricing all publications. The code is determined by the number of pages in the publication. Information pertaining to the pricing codes can be found in the current issues of the following publications, which are generally available in most libraries: Energy Research Abstracts (ERA); Government Reports Announcements and Index (GRA and I); Scientific and Technical Abstract Reporis (STAR); and publication NTIS-PR-360 available from NTIS at the above address. 


\section{Fundamental studies of the mechanisms of slag deposit formation: Final report}

Austin, L.G.; Benson, S.; Rabinovich, A.; Tangsathitkulchai, M.; Schobert H.H.

Jul 1987

Pennsylvania State Univ., University Park (USA). Coll. of Earth and Mineral Sciences

Reproduced and Distributed by:

U.S. DEPARTMENT OF ENERGY

Office of Scientific and Technical Information

P.O. Box 62

Oak Ridge, TN 37831 
FUNDAMENTAL STUDIES OF THE MECHANISMS OF SLAG DEPOSIT FORMATION

REPORTING PERIOD: FInal Report

I. G. Austin

S. Benson

A. Rabinovich

M. Tangsath1tkulcha1

H. B. Schobert

July 1987

Contract No. DE-FG22-84PC70770 
Introduction . . . . . . . . . . . . . . . . . . . 1

The Drop-Tube Furnace. . . . . . . . . . . . . . . . . 5

Gas-fired Furnace . . . . . . . . . . . . . . . . 5

Electrically Heated Furnace . . . . . . . . . . . . 20

Ash Deposition Probe . . . . . . . . . . . . . . . . . 23

Characteristics of Test Coals. . . . . . . . . . . . . . 27

Characteristics of Deposits Produced in a Laboratory Furnace... . 49

Effects of Furnace Conditions on Deposit Formation . . . . . . . . 85

Gas Velocity. . . . . . . . . . . . . . . 85

Constrictor Angle ... . . . . . . . . . . . . . . . 85

Hot Zone Temperature. . . . . . . . . . . . . . . . 88

Physics and Chemistry of Fly Ash Sintering . . . . . . . . . . 91

Proposed Mechanism of Depos1t. Formation. . . . . . . . . . . . 112

Formation and Transportation of Ash Particles. . . . . . . . . 112

Adhesion of Ash Particles on Heat Exchange Surfaces . . . . . . . 113

Build-up of the Deposit:. The Sticking Process., ., , , . , , 141

Development of Deposit Strength by Sintering. . . . . . . . . 157

Conclusion. . . . . . . . . . . . . . . . . . 180

Llterature C1ted. . . . . . . . . . . . . . . . 188 


\section{INTRODUCTION}

The predominant mode of combustion in utility boilers is pulverized coal firing. Pulverized coal fired boilers are generally designed for volumetric heat release rates which give a high temperature to the steam entering the turbine and hence a high generation efficiency. The behavior of inorganic constituents during combustion is one of the most important aspects that influence efficient utility boiler operation. The inorganic constituents associated with coal are converted to ash and vapor phase species during combustion and can form deposits in the boiler. This problem is aggravated by the high temperatures $\left(1500-0^{\circ} 650^{\circ} \mathrm{C}\right)$ of the pulverized coal flame. Deposition can occur on both the radiative and convective. portions of the boiler. The removal of such deposits requires significant capital investments in on-line removal devices.

As a consequence of ash deposition, the heat transfer from the flame to the surfaces transferring heat to water or steam is reduced, resulting in lower steam production and causing a derating of the boiler. Problem coals cause rapid ash deposition and can eventualig lead to an unscheduled shutdown of a boiler. The steel heat transfer tubes can also be damaged by corrosive constituents in the ash or vapors. Large deposits in the upper furnace area can break away from the wall tubes under their own weight, fall the considerable distance from the roof to the floor, and as a result damage tubes in the bottom of the boiler. 
The loss of boiler efficiency, availability, and the cost of operational problems show that the need for additional scientific investigation on the ash deposit formation process is readily justified. The understanding of the ash deposition process has become more important as the capacity of power plants grows and new low-grade coals containing high ash contents are introduced to meet increasing energy demands.

The process of ash deposit formation is very complicated and complex. A complete understanding of this, process requires knowledge of chemical composition and distribution of inorganic constituents in coal, transformations and reactions of the inorganic constituents in the flame, ash transport mechanisms, initial adhesion of ash particles to heat transfer surfaces and subsequently to each other to form a deposit, and further interactions of the deposited ash to grow a strong deposit. The interactions of deposited ash that cause changes in physical and chemical properties in an aged deposit are due to processes such as sintering, chemical reactions, and melting. The degree of these changes increases as the deposit grows from the heat transfer surfaces where it forms. All of these physical and chemical changes during the deposit formation process are not only coal-specifle but also are strongly dependent on the boiler configuration and operating conditions. As a consequence, a precise and quantitative knowledge of the ash deposit formation mechanism has not yet been obtained. 
The sintered strength of the ash deposit ultimately determines whether or not the accumulation can be removed from the boiler tubes by the sootblowers. If the ash particles do not sinter strongly in the deposit, they are easily blown off by the sootblowing operation. When particles sinter strongly, however, such deposits may be so resistant to fracture that normal sootblowing operations will not remove the accumulated ash from these surfaces.

The process of ash sintering to form a strong deposit mass, which follows the deposit initiation and formation, is also very complex. Fly ash is a heterogeneous material and the sintering process is often accompanied or preceded by one or more specific chemical reactions involving certain inorganic constituents in a particular ash particle. Within the ash deposit, the process of sintering and chemical reactions proceed at different rates at different locations depending on the local time-temperature history. In addition, there are many factors such as ash particle shape, particle size and distribution of sizes, furnace temperature, and atmosphere that influence the course of an ash sintering process. These factors complicate the determination of the mechanisms of ash sintering, and as a result, there is not yet sufficient information to understand the mechanisms responsible for the ash sintering involved in the deposit formation process.

The formation of tenacious deposits during the combustion of 
Western coals appears to be directly related to the formation of low melting point alkali and alkaline earth aluminosilicates. Many Western coals contain significant quantities of sodium, which will volatilize during: combustion, become dispersed throughout the gas stream, and later condense on other ash particles and on metal surfaces. Some sodium compounds in coal ash related systems melt at relatively low temperatures (approximately $900^{\circ} \mathrm{C}$ ). The primary thrust of most of the past research on deposit formation from the combustion of Western coals has concentrated on the formation, of melilite type crystalline phases and sodium content of the coal ash. It has been proposed that the sodium-containing material, possibly melilite, provides a binding matrix to fuse ash particles together. The mechanism of formation of melilite may be the key to understanding the depositional processes of Western low-rank coals.

All of the present empirical indices used to predict the melting and deposit-forming behavior of inorganic constituents during combustion are based on bulk ash analysis. The methods work to a limited degree but are always suspect when dealing with an unfamiliar coal because of the wide variations in ash-forming species. Hence, there exists a need for a better fundamental understanding of the formation of deposits by means of closely controlled laboratory-scale experiments and application of theoretical considerations to predict ash melting behavior. 
THE DROP-TUBE FURNACE

Most of the data presented in the major sections of this report which follow were obtained using an externally heated, down-fired laminar flow furnace. These devices are familiarly known as drop-tube furnaces. Although other equipment was also used in the work reported here, the central importance of the drop-tube furnaces is such that their design and operating characteristics merit full discussion first, before the data and results obtained from them are presented.

\section{Gas-fired Furnace}

This study used vertical, externally heated tube furnaces which burned coal passed in a thin stream down the tube. The tube was heated to simulate the time - temperature history of a pulverized coal flame in a utility boiler. The gas-fired furnace was designed to maintain a combustion zone temperature of up to $1750^{\circ} \mathrm{C}$ inside the muffle tube to simulate the flame zone of a boiler, with exit gas temperatures between 1000 and $1300 \circ$. The length of the furnace, diameter of the muffle tube, coal feed rate, and air flow rates were all dictated by particle residence time, which was selected to be between 1 and 2 seconds under laminar flow conditions. In addition, an aif/fuel ratio giving $20 \%$ excess air was essential to simulate the combustion 
conditions of a utility boiler. A pulverized coal feed was used in the tube furnace, giving micrometer-sized.ash particles. The fly ash formed was accelerated and then impacted on an oxidized steel substrate held at a temperature comparable to that of a waterwall tube surface.

The general arrangement of the test system is shown in Figures 1 through 5. The muffle furnace tube, made of $99.8 \%$ fused alumina, is $6.35 \mathrm{~cm}$ internal diameter $x 90 \mathrm{~cm}$ long. It has a zone of maximum temperature about $50 \mathrm{~cm}$ long. It is heated by three tangentially fired natural gas - air burners; the temperature is controlled by adjusting the air/fuel ratio. In general, gas temperatures along the centerline of the furnace tube are about $30^{\circ} \mathrm{C}$ lower than wall temperatures at the same position within the furnace hot zone.

The coal feed system originally used a fluidized bed feeder which entrains pulverized coal in the primary aif stream (about 1 liter/min). The feeder assembly rests on a balance to monitor the coal feed rate continuously. The fluidized bed feeder used caused erratic feed rates when attempts were made to feed -200 mesh coal. The solution to this problem in the past was to use a sized fraction (60 325 mesh) of coal. Lator in thu piojuct an improved feed system was developed, based on a spouting bed feeder.

The spouting bed feeder consists of two main components, an 


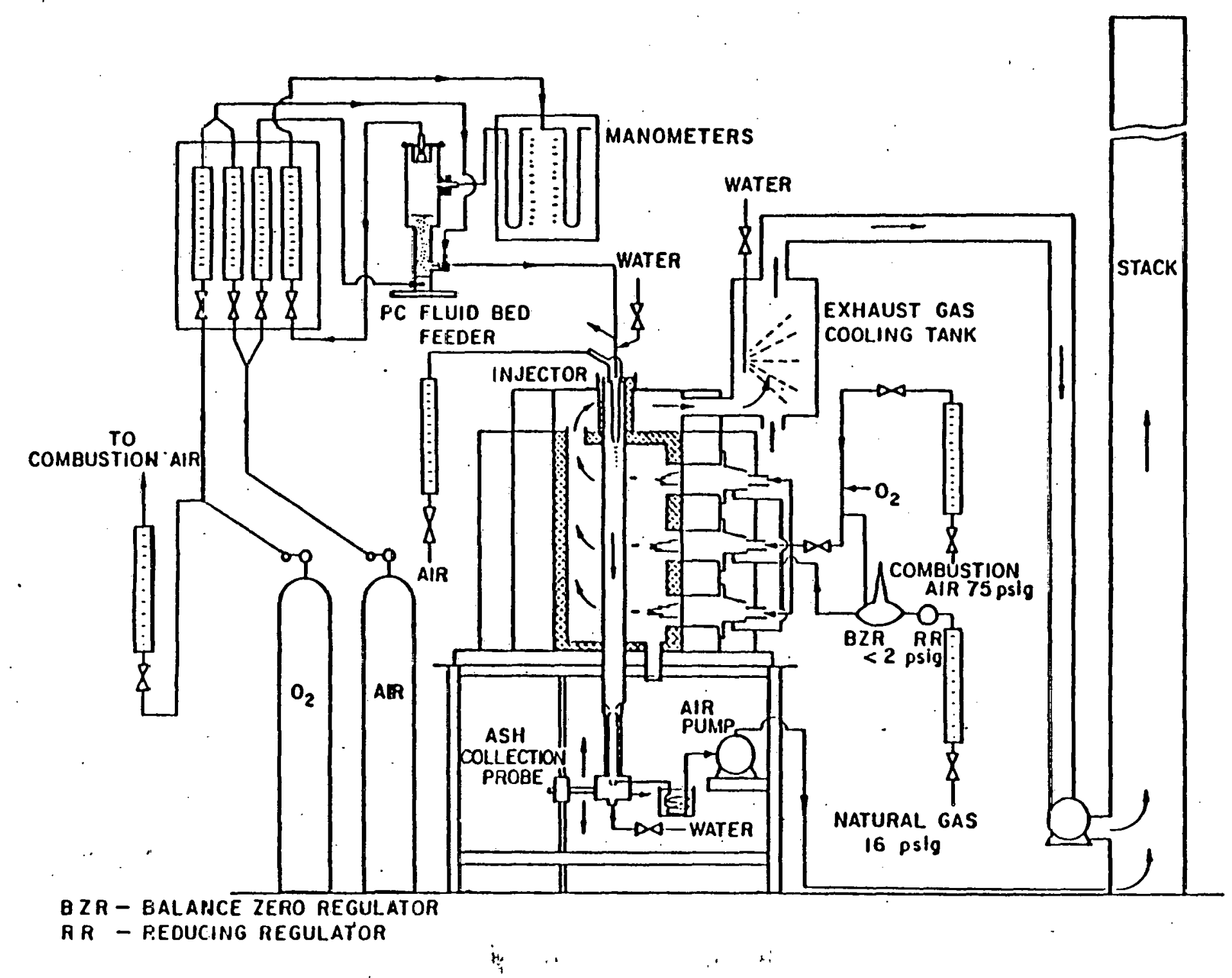

Figure 1. Vertical externảly-heated tube furnace system. 


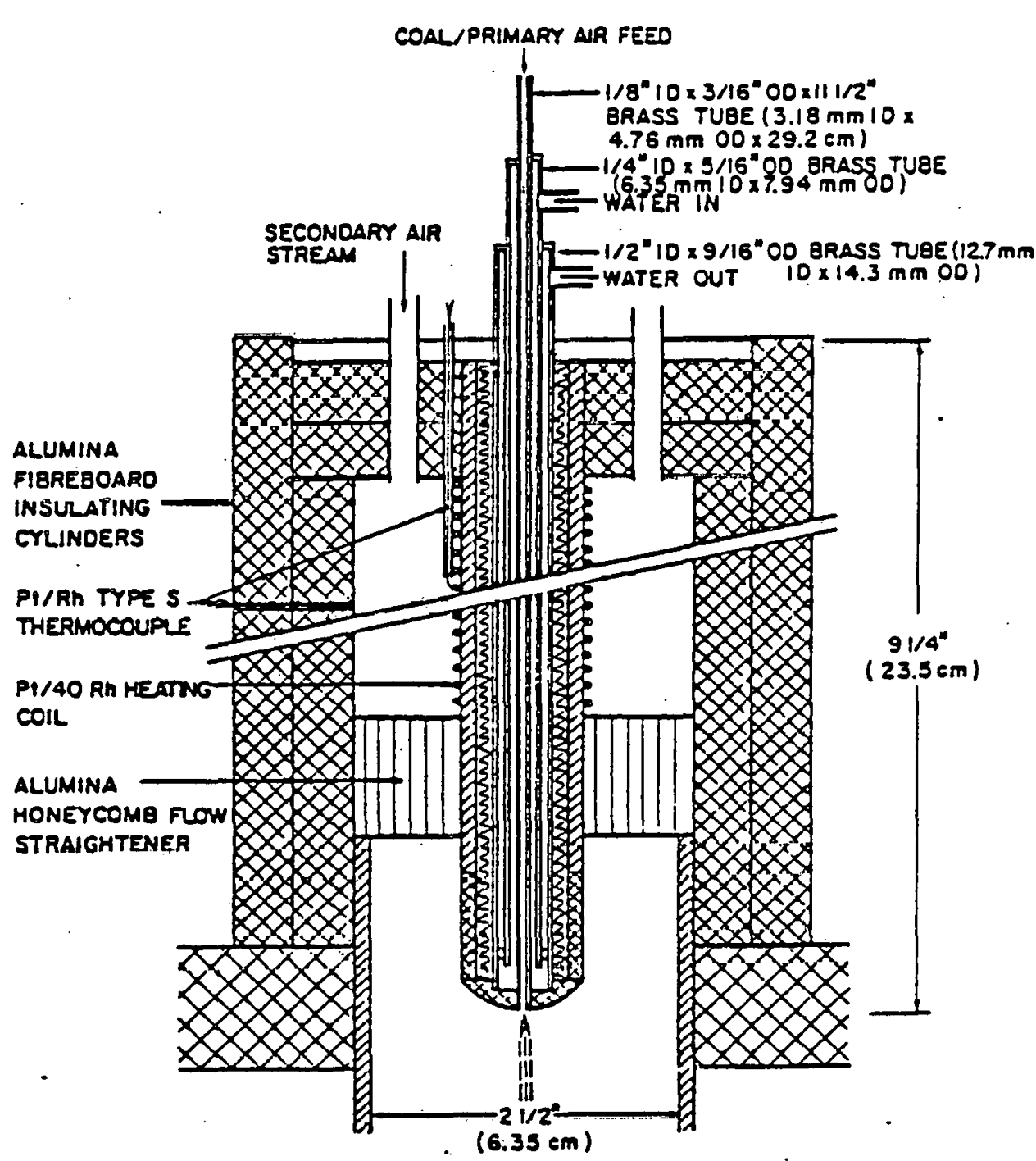

Higure 2. Vertical externally-heated tube furnace; injector and preheater section. 


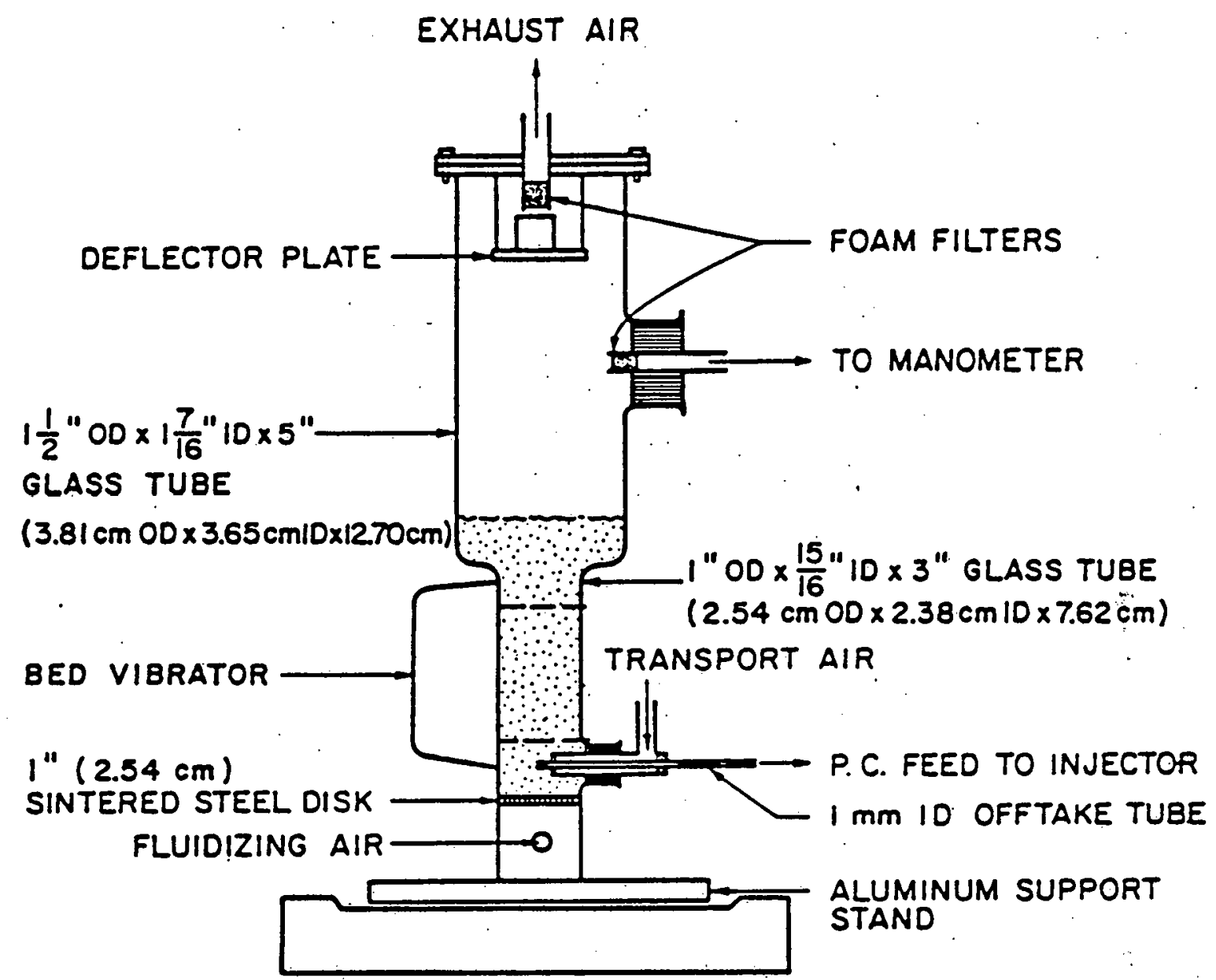

Figure 3. Vertical externally-heated tube furnace; fluidized bed feeder. 


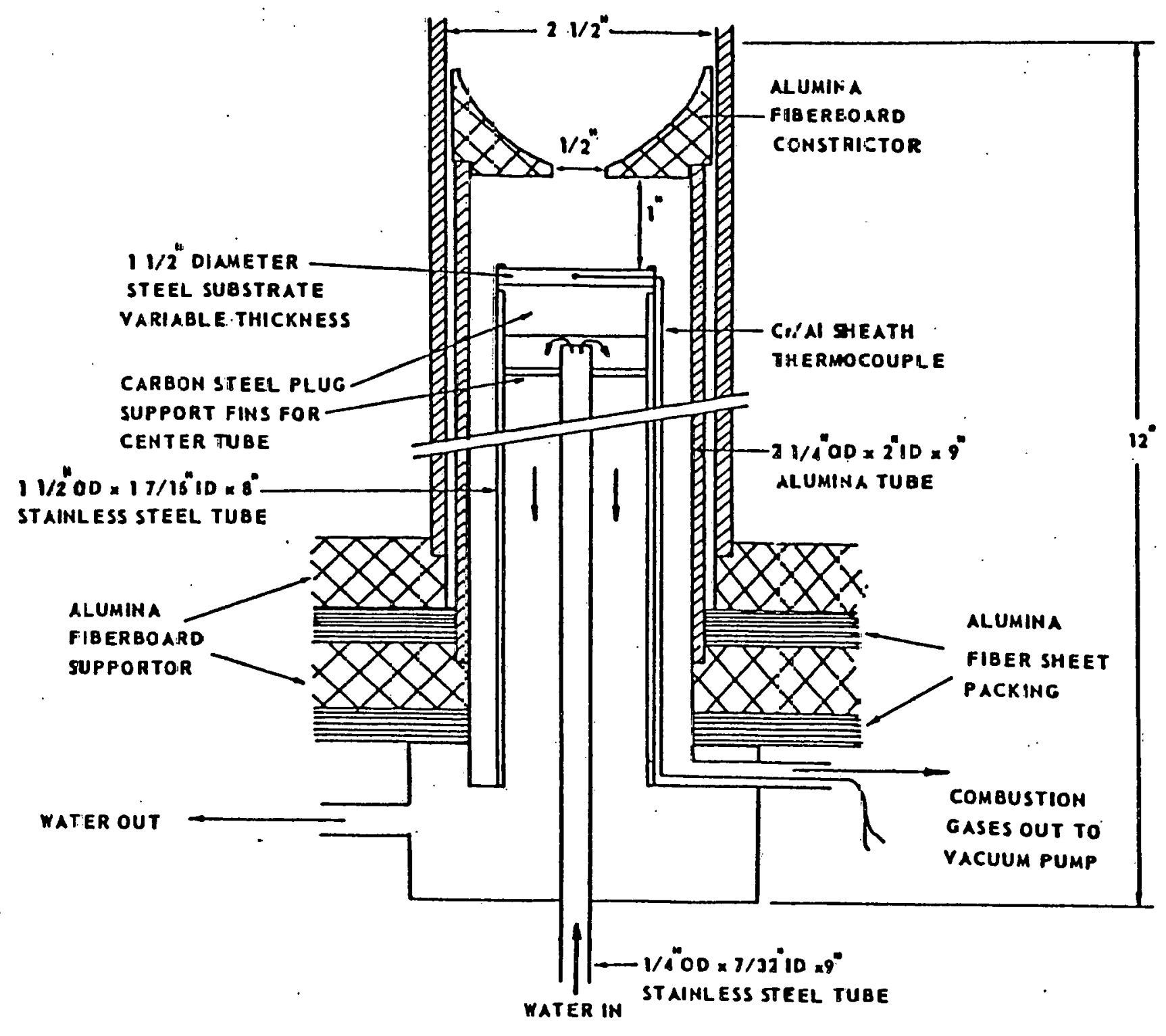

몽

Figure 4. Bottom of vertical externally-heated tube furnace; constrictor and test substrate. 


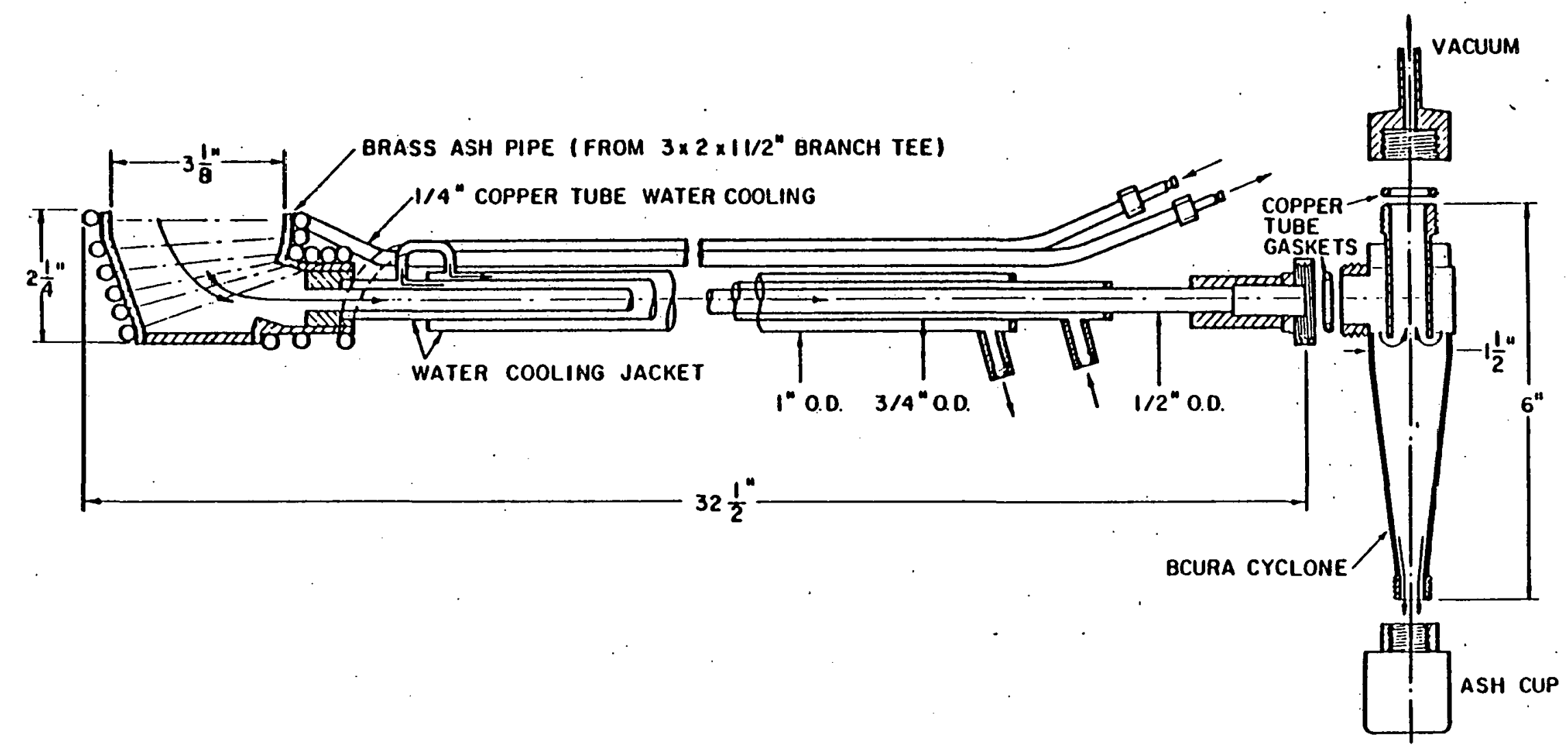

Figure 5. Pipe/cyclone ash probe.

$$
\text { i. ; : + } \div
$$


air pump and a 1 liter Imhoff cone, and is shown in Figure 6 . The pump is used to provide a circulating gas flow to agitate and transport the coal up the spouting tube. The air stream spouts the coal to the top of the feeder where it is deflected and settles down toward the take-off ports. A tangential air jet is used to fluidize the coal at the bottom of the feeder, preventing bridging and aiding coal flow to the spouting tube. The feed rate is controlled by regulating the air circulation rate and the amount of make-up air admitted. Like the fluidized bed feeder, the spouting bed feeder also rests on a top-loading balance to provide continuous monitoring of the coal feed rates.

The performance of the spouting bed feeder is generally adequate for the drop tube furnace; for example, for a desired feed rate of $0.33 \mathrm{~g} / \mathrm{min}$ the deviation over a 40 minute period was $0.04 \mathrm{~g} / \mathrm{min}$. However, the feeder will intermittently clog when feeding 400 mesh coal and even some 200 mesh coals. The erratic feeding may be a problem of static charging inside the plastic cone. Glass cones may be preferable for this application. Also, when the total sample is less than 20 - 30 grams problems in fluidization produce erratic feed rates.

An additional feeder was constructed to feed consistently small (i.e., about 5 grams) of coal. This feeder is useful when only a small quantity of coal or other sample is available for combustion testing. A diagram is shown in Figure 7. The feeder uses a 6 volt DC motor and gear box to rotate a brass cylinder at 


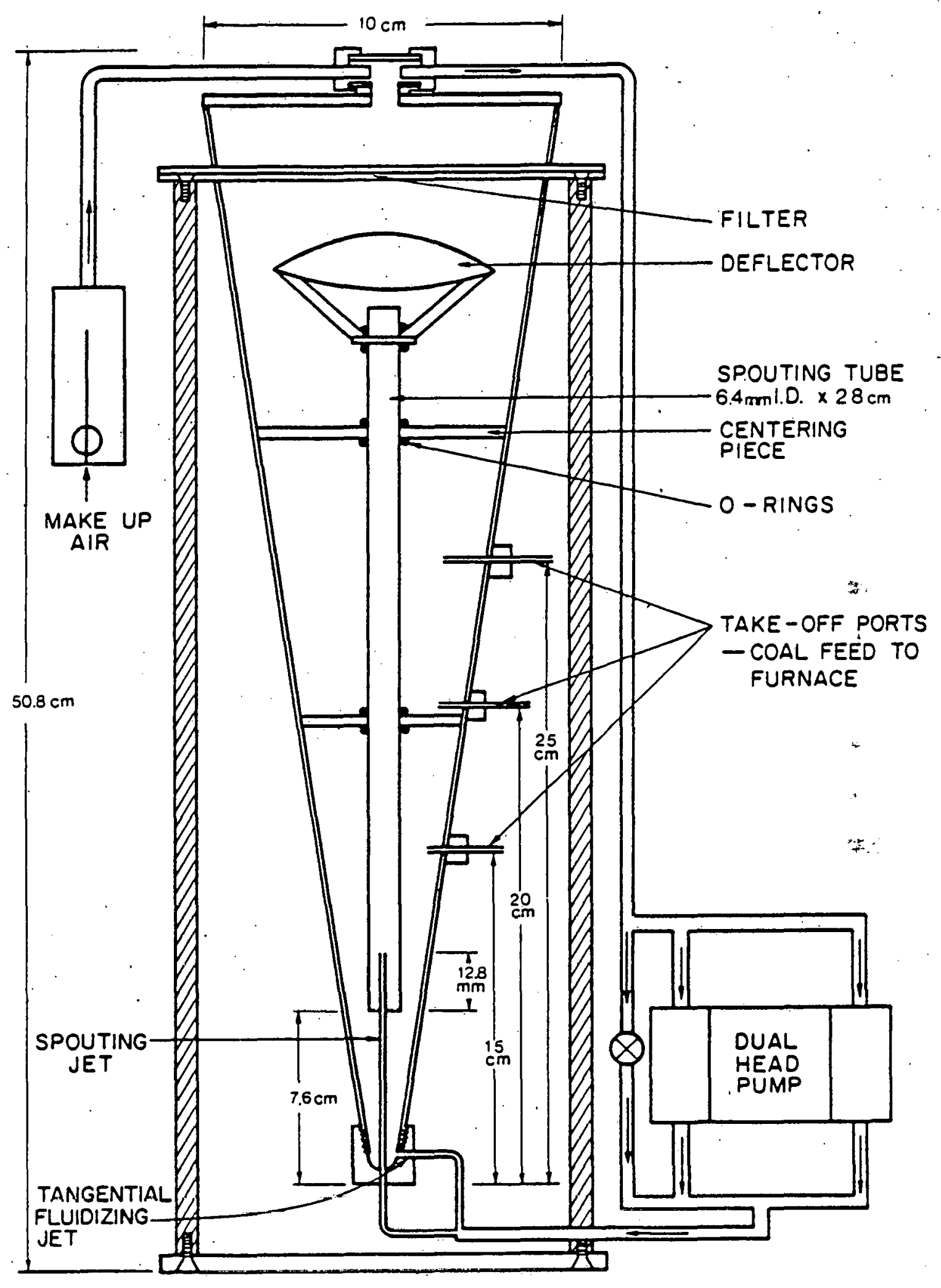

Figure 6. Spouting bed coal feeder. 

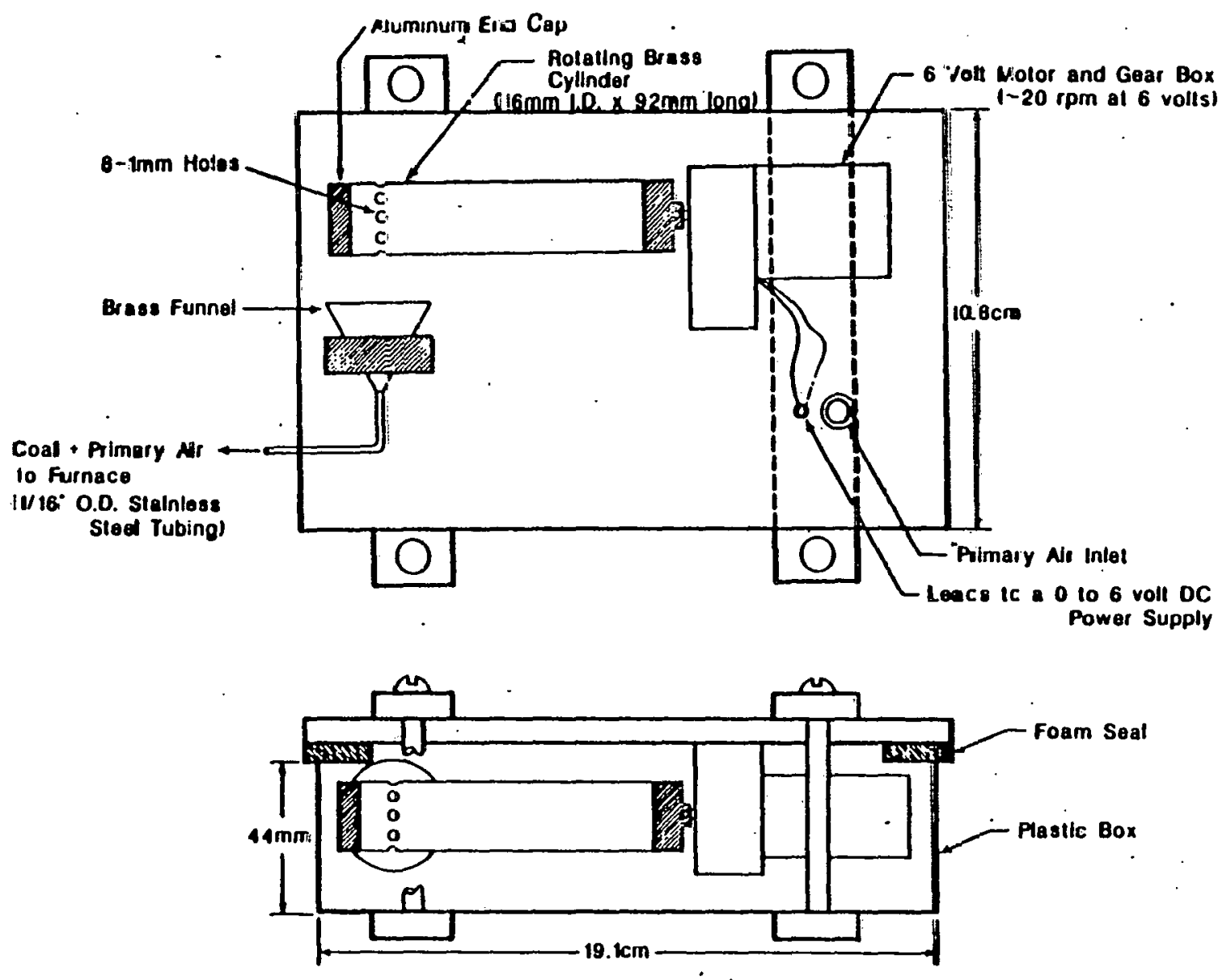

Figure 7 . Rctating cylinder feeder. 
0 - $20 \mathrm{rpm}$. The cylinder has eight $1 \mathrm{~mm}$ diameter holes into which the sample is placed. As the cylinder is rotated coal falls from the holes into the funnel, where it becomes entrained in the primary air. The coal feed rate is determined by the rotational speed of the motor and the tilt of the cylinder from the horizontal position.

The coal - primary air mixture is injected into the furnace through the water-cooled injector probe. Preheated secondary air (about 3 liters/min) enters the furnace through a flow straightener. The gas velocity profiles at various axial positions at the hot zone temperature $\left(1500^{\circ} \mathrm{C}\right)$ were calculated using a numerical computer solution of the Navier-stokes equations. The result is shown in Figure 8 . The gas stream where the injected particle resides in the primary air stream is initially decelerated in about $5 \mathrm{~cm}$ from the injector tip, before blending into a uniform $21.6 \mathrm{~cm} / \mathrm{sec}$ velocity profile with the main stream. The gas velocity of $21.6 \mathrm{~cm} / \mathrm{sec}$ was used to calculate the particle residence time in the $50 \mathrm{~cm}$ hot zone to be 1 to 2 seconds, assuming a 100 micron particle of density 1.5 g/cm ${ }^{3}$. The laminar velocity profile keeps the burning particles in a thin ray in the center of the furnace without striking the furnace walls. The gas stream and fly ash are accelerated by a constrictor ( $1.3 \mathrm{~cm}$ diameter ceramic nozzle) prior to impingement on the substrate. Exit gases are removed by a vacuum pump to prevent back-pressure build-up in the furnace tube. 
TOP OF FURNACE

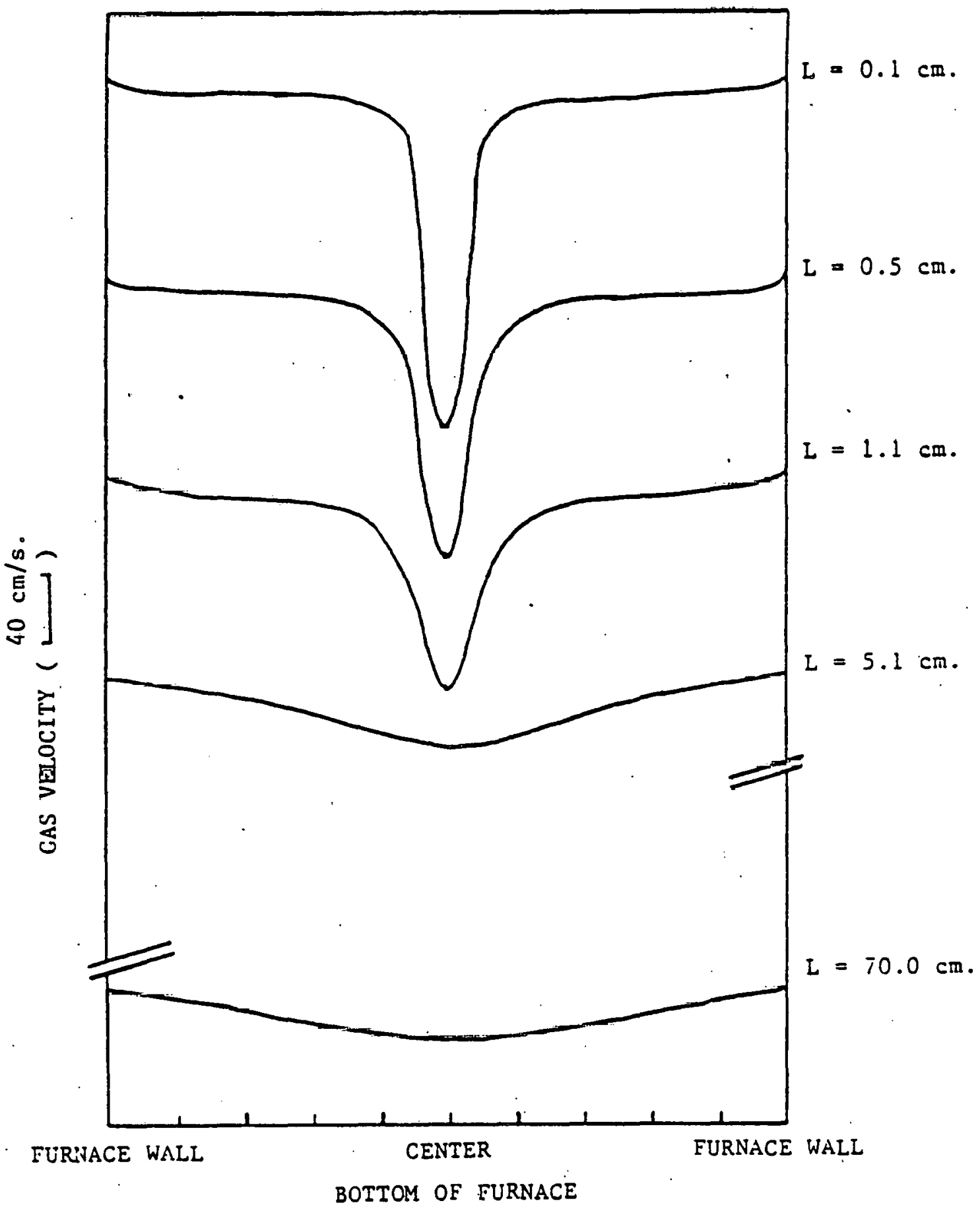

Figure 8. Gas velocicy profile in the vertical externally-heated tube furnace: $\mathrm{L}$ is the distance along the tube furnace. 
The procedure for ignition and heat-up of the vertical tube furnace has been documented by Abbott.1 The furnace was normally operated with a hot zone wall temperature of $15000^{\circ} \mathrm{C}$. The gas temperature passing through the annulus around the substrate was $11000^{\circ} \mathrm{C}$; the temperature "seen" by the deposit was between 1100 and $1300^{\circ}$ C. (These temperatures were measured by using pyrometric cones, which simulate the heat transfer conditions to a cone of deposit.) The total combustion air was approximately 4 liters/minute, giving approximately $20 \%$ excess air for the pulverized coal feed rate of 0.33 grams/minute. The constrictor dimension of $1.3 \mathrm{~cm}$ gave gas velocities of $3-4 \mathrm{~m} / \mathrm{s}$. The substrate in the collector probe was maintained at 5000 C before starting deposition. In tests in which data was obtained under conditions which deviated significantly from these, the specific test conditions will be described in the accompanying text.

Temperature profiles are shown in Figure 9. These temperatures were measured by a shielded suction pyrometer in the range $1450-1650 \circ \mathrm{C} .1$ The corresponding wall temperatures, from thermocouples, are also plotted. In general, the gas temperatures along the centerline of the furnace were about $30^{\circ}$ lower than the corresponding wall temperature. The estimated particle residence times versus gas temperature are compared with a full-scale boiler firing low-rank coal in Figure 10. The particle residence times were calculated by assuming the particle velocities to be equal to the sum of the centerline gas velocity and the terminal particle velocity (from Stokes' Law). The particle residence 


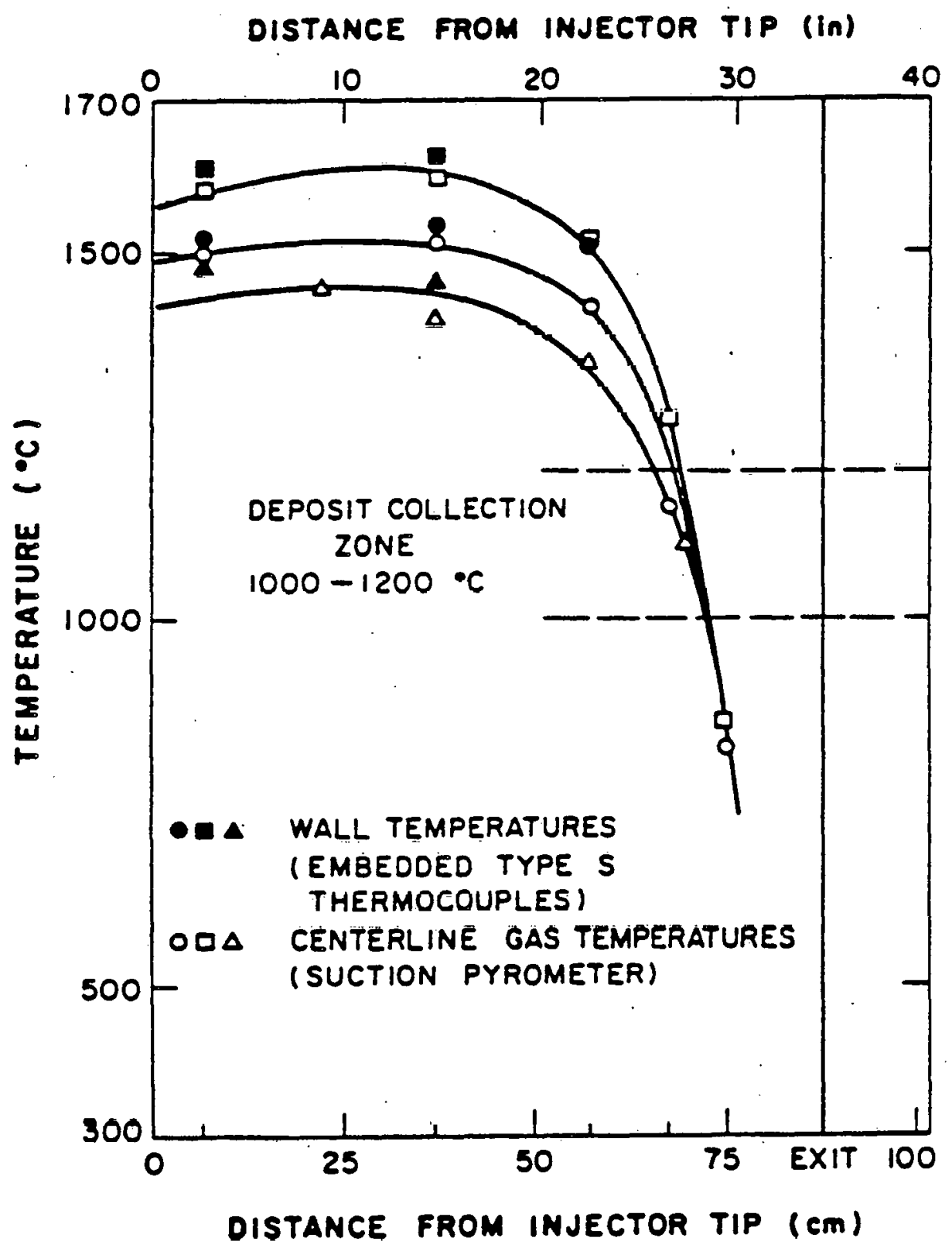

Figure 9. Gas-fired furnace temperature profile. 


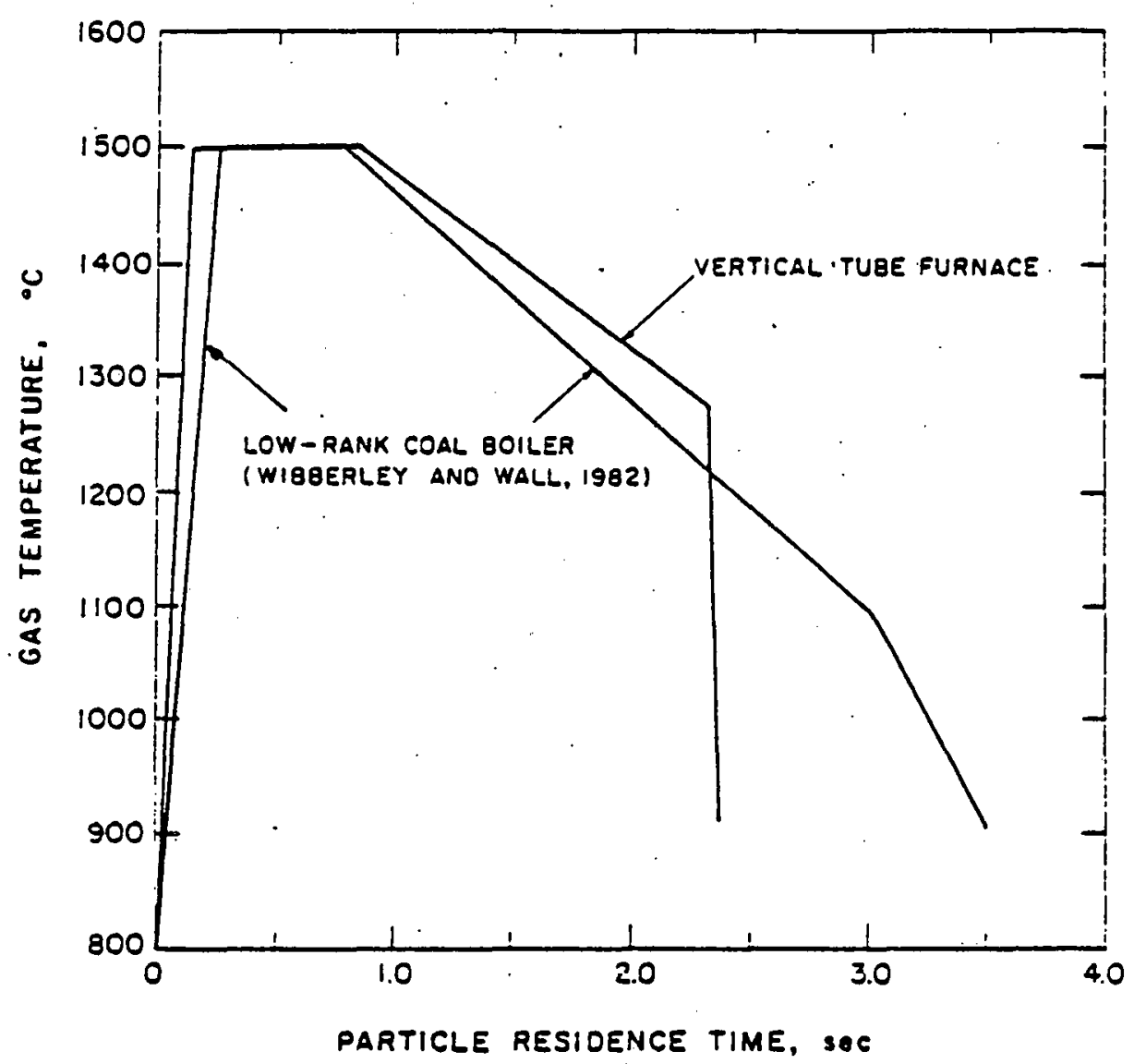

Figure 10. Estimated particle residence time versus gas temperature for the vertical tube furnace operated at $1500^{\circ} \mathrm{C}$ as compared to a full scale luw-rank cual boller. 
times are dependent on particle size and density, and were calculated assuming an initial size of 75 micrometers and a density of $1.8 \mathrm{~g} / \mathrm{cm}^{3}$ when injected into the hot zone. As the coal particle burns, it decreases in size and increases in density. After the particle has passed $40 \mathrm{~cm}$ through the tube a size of 40 micrometers and a density of $2.5 \mathrm{~g} / \mathrm{cm}^{3}$ were assumed; the corresponding values for $60 \mathrm{~cm}$ from the point of injection were assumed to be 20 micrometers and $2.8 \mathrm{~g} / \mathrm{cm}^{3}$, respectively. Thus the total particle residence time is about 2.4 seconds.

\section{Electrically Heated Furnace}

An electrical resistance furnace was designed on the same basis as the gas-fired furnace. A diagram of the electrical resistance furnace system is shown in Figure 11. The hightemperature furnace contains a $51 \mathrm{em}$ hot zone heated by 20 silicon carbide glow bars and can maintain a maximum temperature of $1550^{\circ} \mathrm{C}$.

The preheat-injector system is shown in Figure 12 . The system has two heating coils to heat the secondary air to a maximum of $1100^{\circ} \mathrm{C}$ prior to entering the main furnace. A mullite flow straightener with $1.6 \mathrm{~mm}$ square cells is used to provide laminar flow of secondary air from the preheat-injector system. The water-cooled injector is the same design as that of the gasfired furnace. 
COAL AND PRIMARY AIR

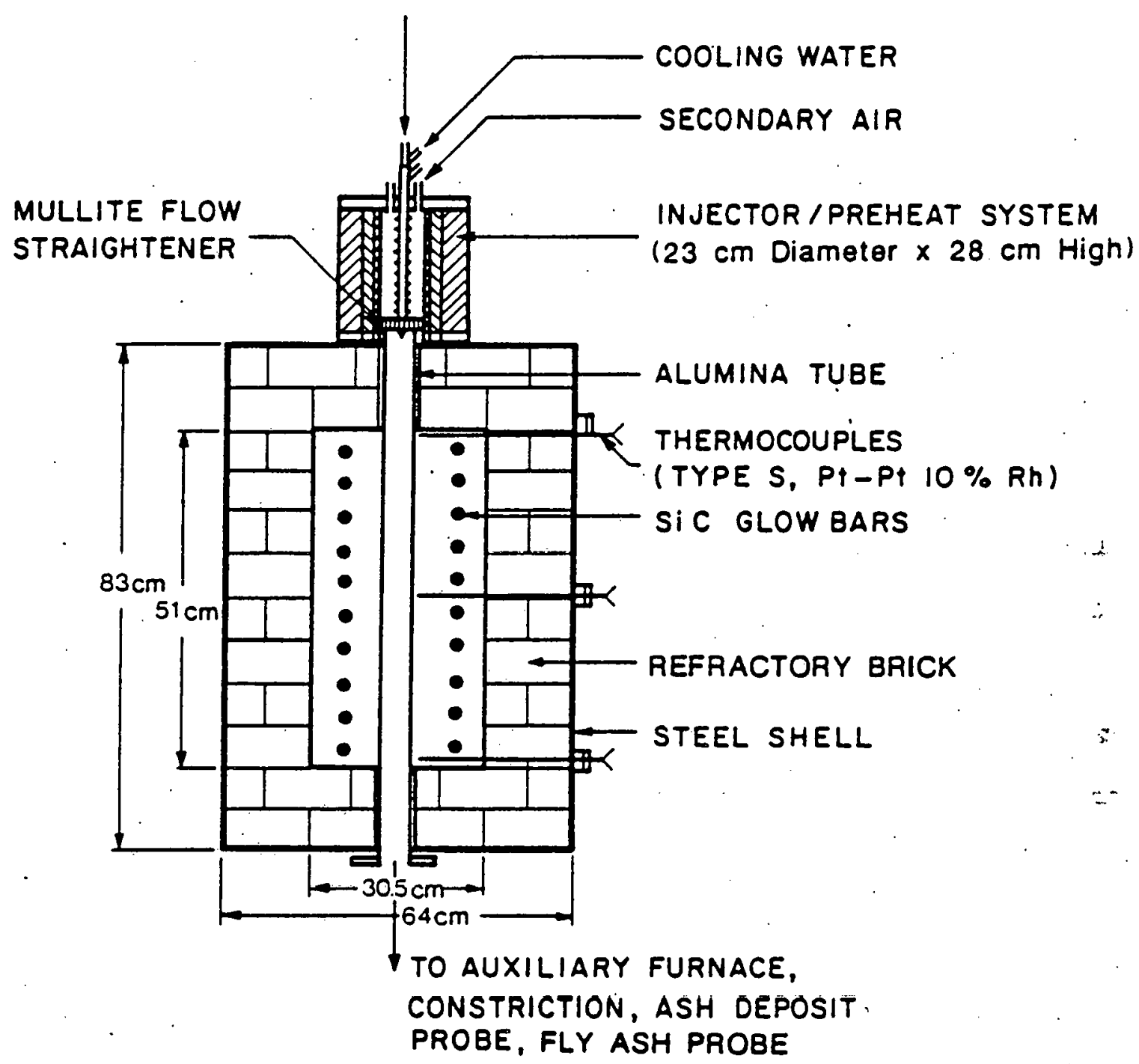

Figure 11. Diagram of main electrical resistance furnace. 


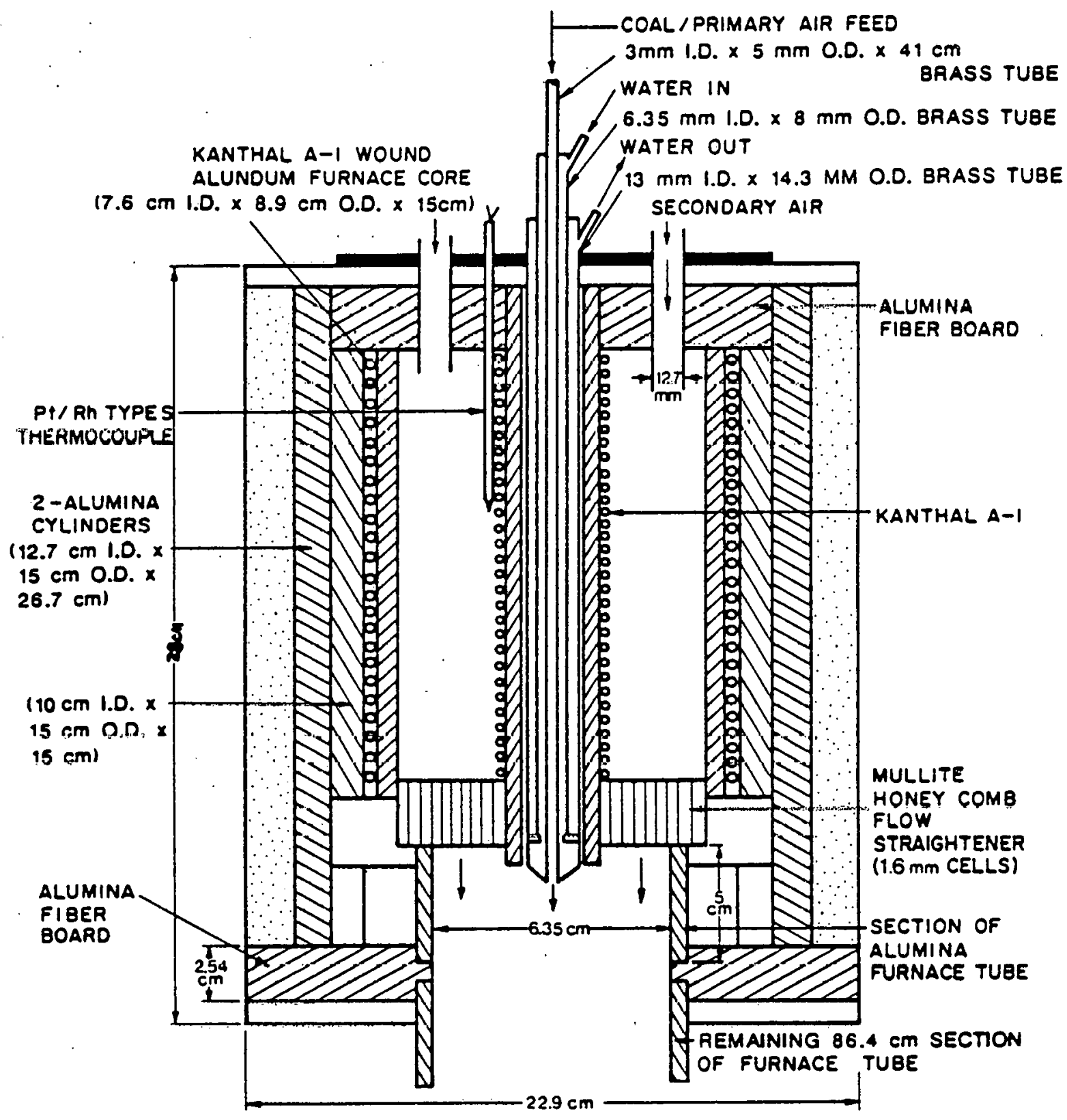

Figure 12. Preheater and injector system. 
Examination of deposits collected on the probe or of fly ash collected without the probe showed negligible carbon content, indicating high levels of burn-out. No fly ash was collected on the furnace tube, and negligible amounts were found on the constrictor. Quadruplicate tests on $10 \mathrm{~g}$ lots of a Powder River Basin coal passed through the furnace in 30 minutes gave deposit masses of $313,324,302$, and. $311 \mathrm{mg}$, showing good reproducibility.

\section{Ash Deposition Probe}

The water-cooled ash deposition probe is shown in Figure 13 . A machined boiler steel substrate $3.8 \mathrm{~cm}$ diameter by $0.64 \mathrm{~cm}$ thick is attached to the top of the probe. The substrate temperature is maintained at a value selected between $350-550 \circ \mathrm{C}$ by adjusting the cooling water flow and the tightness of the screws that hold the substrate to the probe. The temperature is monitored by a chromel-alumel thermocouple. A constrictor having a $1.27 \mathrm{~cm}$ nozzle is used to accelerate the gas flow to about $3-$ $5 \mathrm{~m} / \mathrm{sec}$. The substrate is placed $2.5 \mathrm{~cm}$ below the constrictor.

The substrate materials are prepared from type 1040 carbon steel, supplied by the Babcock and Wilcox Company. The substrates are polished with 600 grit silicon carbide. The substrates are oxidized in air at $400^{\circ} \mathrm{C}$ for 20 hours to produce an oxide layer on the steel. 


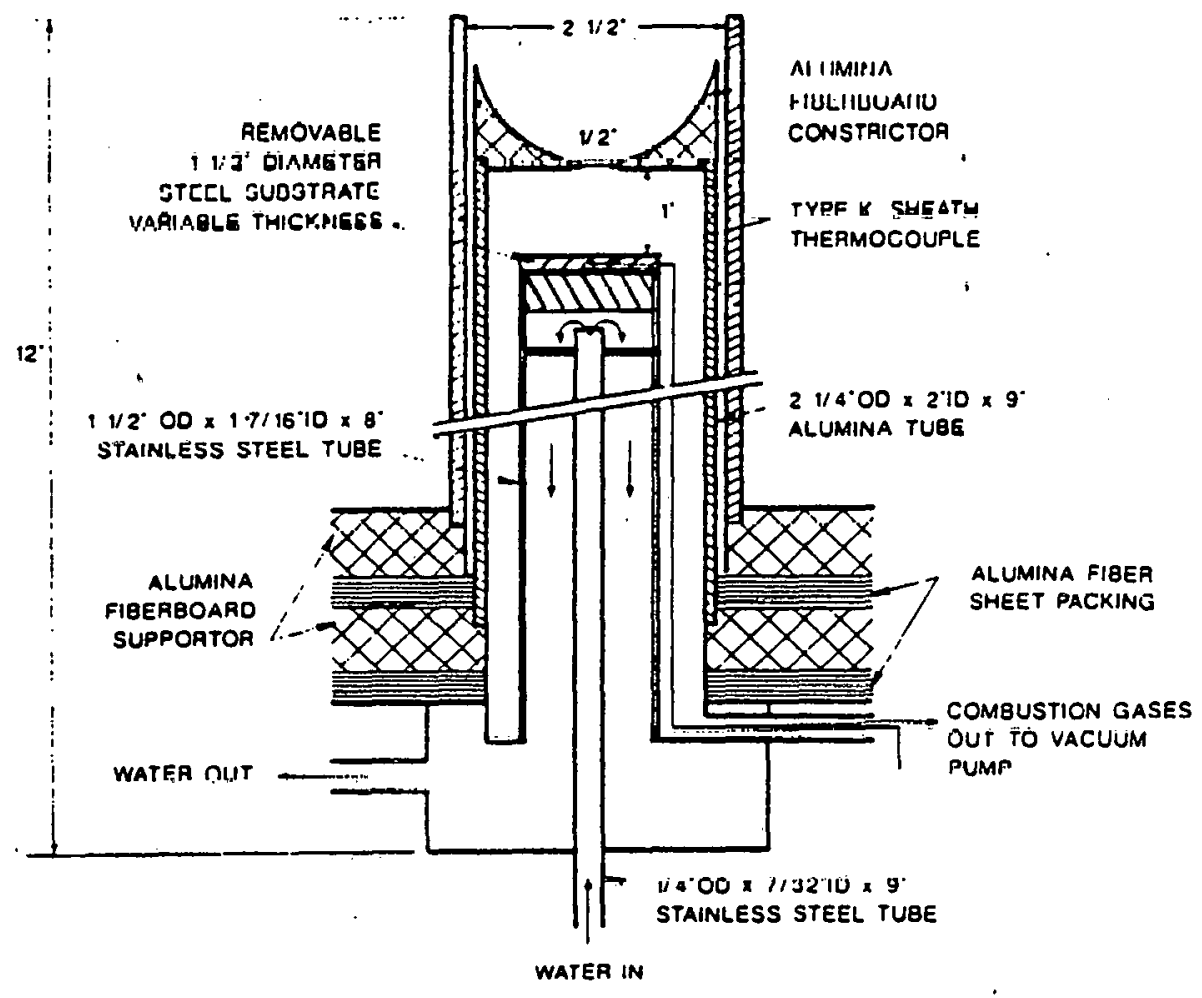

Figure 13. Bottom of vertical tube furnace, constrictor and ash deposilion probe. 
The temperature of the gases entering the constrictor can be varied between $1000-1300 \circ \mathrm{C}$ by adjusting the position of the constrictor or deposition probe in the base of the furnace. The vertical position of the probe in the furnace is critical; a variation of its position by $1 \mathrm{~cm}$ changes the temperature in the deposition region by $50 \circ \mathrm{C}$. The gas temperature profile in the region where the deposit forms was determined using pyrometric cones ranging in melting point from $900-1270 \circ \mathrm{C}$. The cones were cut to various heights and placed at various positions across the substrate. The temperature profile for a configuration with the substrate $74.1 \mathrm{~cm}$ from the tip of the coal injector is shown in Figure 14. 


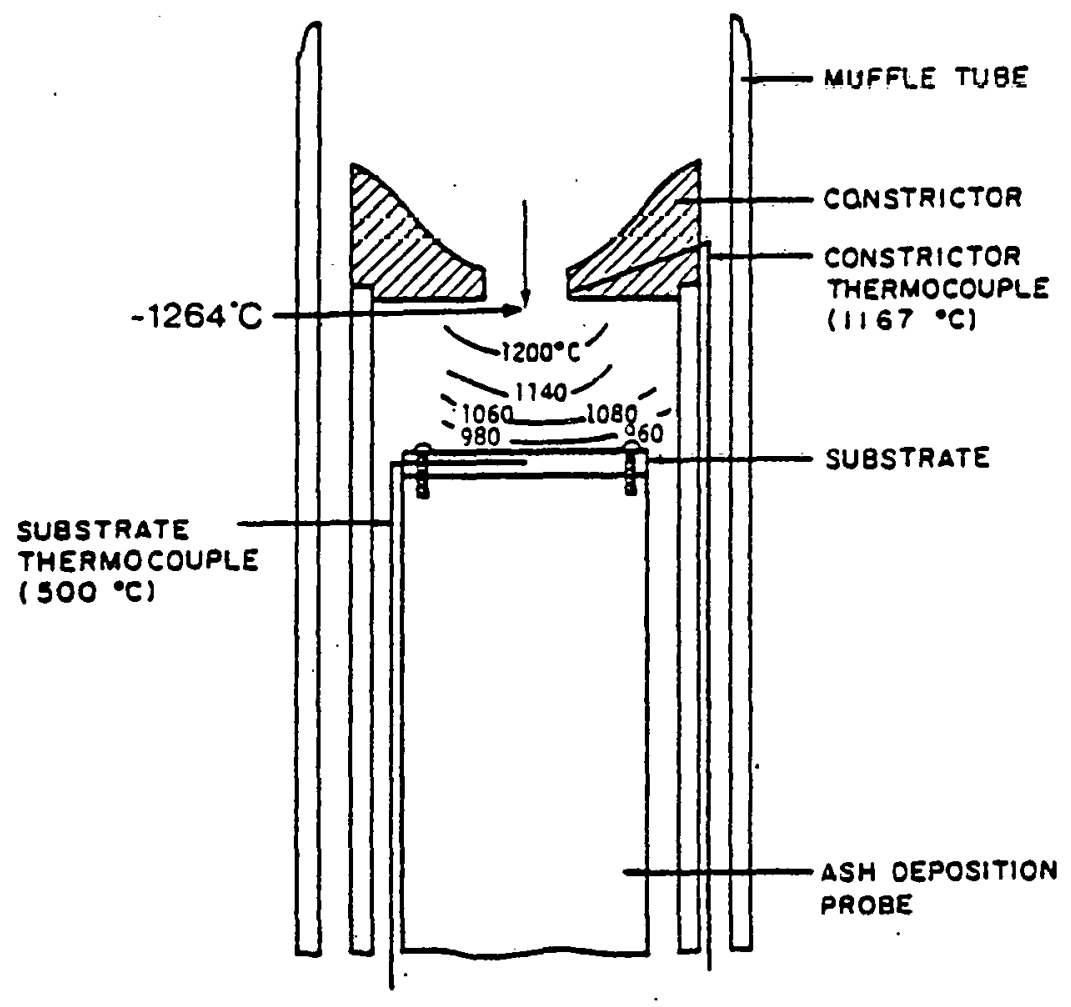

Figure 14. Temperature distribution between constrictor and substrate at $74 \mathrm{~cm}$ from tip of injector. 
CHARACTERISTICS OF TEST COALS

The experimental work covered in this report was performed using two suites of coals. The first included the following coals: Illinois \#6, Pittsburgh \#8, Upper Hiawatha \#1, Upper Freeport, Tunnelton, Decker, a subbituminous coal from the Powder River Region, and Texas and North Dakota Iignites. Analytical data for these coals is given in Tables 1 - 6. The second suite of coals was selected from the major Western coal-bearing regions of the United States. The coals ranged in composition from having most of the ash-forming inorganic constituents organically bound to mostly present as distinct mineral phases. Complete analyses of these coals are given in Tables 7 - 9. Further, the association of the inorganic constituents was determined by chemical fractionation.2 The chemical fractionation data is provided in Tables $10-17$. When it is necessary to distinguish between sets of results obtained from one or the other of these sample suites, they will be referred to as suite 1 and suite 2 , respectively. 
Table 1. Proximate and ultimate analysis of test coals (all on a dry basis with the exception of moisture determination).

Coal Illinols \#6 Pittsburgt: \#8 U.H1awatha 11 U.Freeport Tunnelton Decker Powder River Texas N.Dakota

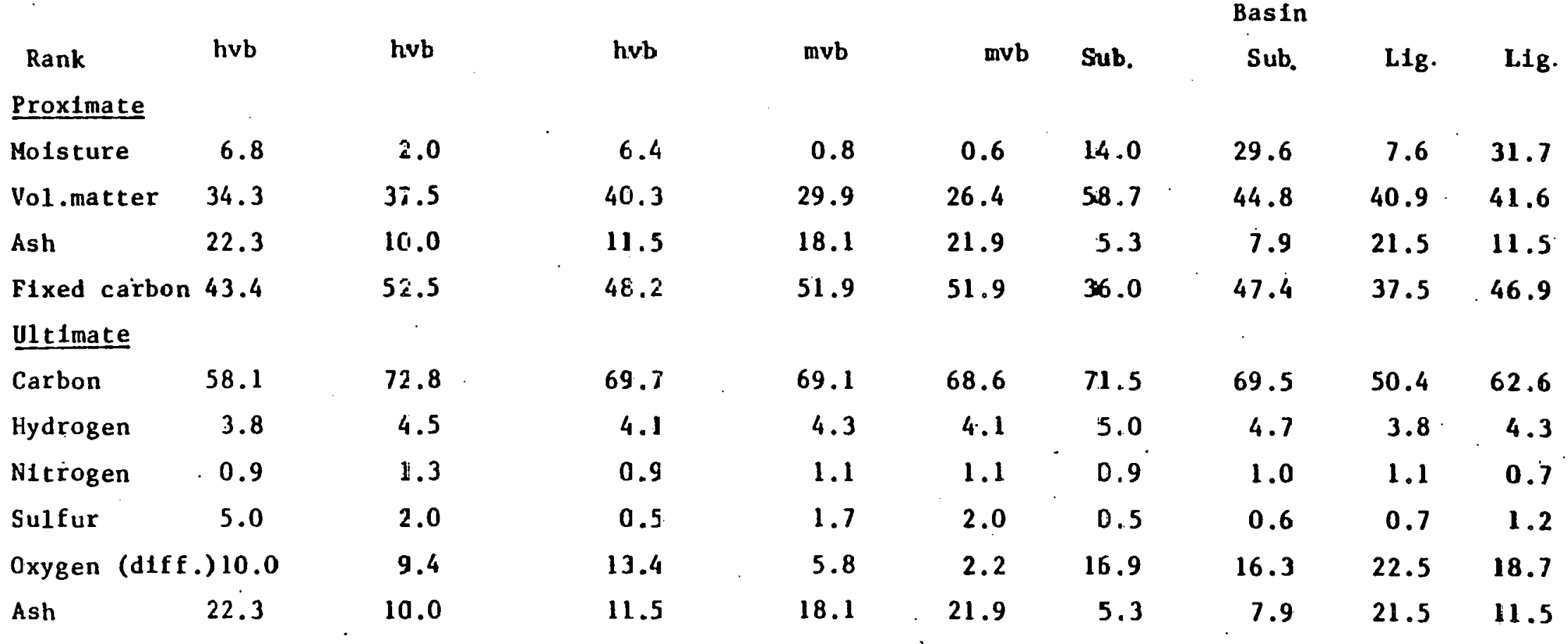

* Source $=$ Mineral Constitution Laboratories, The Pennsylvanta State University, Pa. 


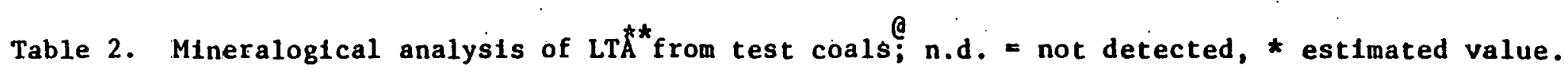

Coal

I1linois $\| 6$ Pittsburgh \#8 U.Hiawatha \#1 U.Freeport Tunnelton Decker Powder River Texas N.Dakota

\begin{tabular}{|c|c|c|c|c|c|c|c|c|c|}
\hline & & & & & & & Basin & & \\
\hline LTA wt.\% & 22.0 & 11.8 & 12.1 & 21.6 & 22.9 & 5.5 & 9.7 & 23.7 & 14.6 \\
\hline Minerals & & & & & & & & & \\
\hline quartz & 25 & 23 & 28 & 25 & 22 & 15 & 15 & $20-25$ & 12 \\
\hline pyrite & 29 & 27 & $2-5$ & 10 & 15 & 5 & n.d. & $1-5$ & 5 \\
\hline calcite & $2-5$ & n.d. & 7 & n.d. & 5 & 6 & 2 & n.d. & 5 \\
\hline gypsum/. & & . & & & & & & & \\
\hline bassinfte & n.d. & n.d. & n.d. & 5 & n.d. & 25 & 25 & $15-20$ & 20 \\
\hline kaolinite & 5 & 25 & 9 & 30 & 18 & 13 & 15 & $30-35$ & n.d. \\
\hline 1liftetmixed & & & & & & & & & \\
\hline layer clays. & $35^{\star}$ & $10^{*}$ & $30^{*}$ & $20^{\star}$ & $30-40^{\star}$ & n.d. & n.d. & n.d. & n.d. \\
\hline feldspar & n.d. & n.d. & n.d. & n.d. & $5-10$ & n.d. & n.d. & n.d. & n.d. \\
\hline ankerite & n.d. & n.d. & $2-5$ & n.d. & n.d. & n.d. & n.d. & n.d. & n.d. \\
\hline Iron sulfate & n.d. & n.d. & n.d. & n.d. & n.d. & n.d. & n.d. & n.d. & $10^{\star}$ \\
\hline
\end{tabular}

+ bassnite is of ten an artifact of LTA process when ashing low rank-coals.

e Source = Mineral Constitution Laboratorles, The Pennsylvania State University, Pa.

"* Low temperature ash. 
Table 3. Spectrochemical analyois of high temperature ash (ASTM) of test coals*.

Powder

Coal Illinols \#6 Pittsburgh \#8 U.Hawatha \#1 U.Freeport Tunnelton Decker River Basin Texas N.Dakota Weight percert of equivalent oxides

\begin{tabular}{|c|c|c|c|c|c|c|c|c|c|}
\hline $\mathrm{SHO}_{2}$ & 48.3 & 51.1 & 51.1 & 54.1 & 50.3 & 26.2 & 25.8 & 48.7 & 18.7 \\
\hline $\mathrm{Al}_{2} \mathrm{O}_{3}$ & 17.5 & 26.9 & $13.4^{\circ}$ & 25.9 & 26.8 & 18.0 & 15.1 & 18.6 & 8.7 \\
\hline $\mathrm{T}^{10} \mathrm{O}_{2}$ & 0.8 & 0.9 & 0.9 & 1.3 & 1.3 & 1.2 & 0.8 & 1.2 & 0.5 \\
\hline $\mathrm{Fe}_{2}{ }^{\mathrm{O}}{ }_{3}$ & 20.9 & 15.2 & 6.2 & 9.6 & 11.0 & 7.6 & 7.4 & 5.6 & 13.4 \\
\hline $\mathrm{MgO}$ & 0.9 & 0.9 & 2.2 & 1.0 & 1.0 & 3.4 & 5.5 & 2.1 & 5.4 \\
\hline $\mathrm{CaO}$ & 4.7 & 0.9 & 14.1 & 1.7 & 2.5 & 15.8 & 24.7 & 9.1 & 18.9 \\
\hline Mno & 0.0 & 0.0 & 0.0 & 0.0 & 0.0 & 0.0 & 0.0 & 0.1 & 0.0 \\
\hline $\mathrm{Na}_{2} \mathrm{O}$ & 0.6 & 0.2 & 2.1 & 0.3 & 0.4 & 8.4 & $1.6^{\circ}$ & 0.3 & 9.5 \\
\hline $\mathrm{k}_{2} \mathrm{O}$ & 1.6 & 2.2 & 0.8 & 2.9 & 2.9 & 0.4 & 0.3 & 0.9 & 0.1 \\
\hline $\mathrm{P}_{2} \mathrm{O}_{5}$ & 0.2 & 0.1 & 0.3 & 0.3 & 0.4 & 0.7 & 0.4 & 0.0 & 0.4 \\
\hline $\mathrm{so}_{3}$ & 4.6 & 0.7 & 8.3 & 1.1 & 2.3 & -17.5 & 18.2 & 11.4 & 21.4 \\
\hline Total & 100.0 & 99.1 & 99.4 & 98.2 & 98.9 & 99.2 & 99.8 & 98.0 & 97.0 \\
\hline
\end{tabular}

* Source $=$ Mineral Constitution Laboratorles, The Pennsylvania State Undversity, Pa. 
Table 4. Fusion temperature of high temperature ash (ASTM) of test coals, ${ }^{\circ} \mathrm{C}$.

$\operatorname{Coa} 1$ Illinols \#6 Pfttsburgh \#8 U.H1awatha \#1 U.Freeport Tunnelton Decker Powder R1ver Texas N.Dakota Basin

\section{Oxidizing Atmosphere}

Inttal

deformation 1280

1430

1170

Softening $\quad 1300$

1460

1180

1470

Hemisphere 1350

1220

Fluid

1370

1490

1310

Reducing Atmosphere

Inittal

deformation 1090

Softening 1120

1310

1120

Hemisphere 1140

1330

1370

Fluid

1180

1420

1150

1180

1390
1420
1450
1480

1450

$1490 \quad 1330$

1270

$1270 \quad 1250$

$1500 \quad 1350$

1290

$1300 \quad 1270$

1510

1360

1310

$1350 \quad 1270$

1330

$1380 \quad 1280$

1220

1210
1350
1420
1480

1380
1410
1430
1490

1130
1160
1180
1190

1270
1280
1290
1300

$\begin{array}{ll}1230 & 1130 \\ 1260 & 1180 \\ 1300 & 1200 \\ 1350 & 1210\end{array}$


Table 5. Sulfur forms of test coals. All valueg are "dry basis" $(w t, z)^{*}$.

Coal

Pyritic sulfur Sulfate sulfur Organic sulfur sulfur

$\begin{array}{lllll}\text { Illinols \#6 } & 1.88 & 0.85 & 2.17 & 4.90 \\ \text { P1ttsburgh \#8 } & 0.76 & 0.22 & 0.89 & 1.87 \\ \text { U.Hiawatha \#1 } & 0.09 & 0.02 & 0.30 & 0.41 \\ \text { U.Freeport } & 0.76 & 0.46 & 0.58 & 1.80 \\ \text { Tunnelton } & 0.95 & 0.25 & 0.61 & 1.81 \\ \text { Decker } & 0.11 & 0.06 & 0.40 & 0.57 \\ \text { Puwder River Dasin } & 0.13 & 0.01 & 0.41 & 0.55 \\ \text { Texas } & 0.03 & 0.04 & 0.69 & 0.76 \\ \text { N.Dakota } & 0.06 & 0.70 & 0.39 & 1.15 \\ \text { * Source = Mineral Constitution Laboratories, The Pennsylvania State } \\ \text { University, Pa. }\end{array}$

Table 6: Chlorido content of test coals, wt. \% $^{*}$.

Coal

Illinois \#6

Pitesburgh \#8

U. HLawatha \#I

U. Freeport

Tunnel ton

Desker

Powder Rlver Basin

Texas

N. Dakota

${ }^{\star}$ Source $=$ Mineral Constitution Laboratories, The Pennsylvania State University, $\mathrm{Pa}$.
Chloride

0.06

0.22

0.08

0.32

0.36

0.03

0.06

0.03

0.04 
Table $7 . \quad$ Mineralogy of low-temperature ash - North Dakota lignitese.

\begin{tabular}{|c|c|c|c|c|c|c|}
\hline Coal & Indian Head & Beulah & $\begin{array}{l}\text { Gascoyne } \\
\text { Red } \\
\end{array}$ & $\begin{array}{l}\text { Gascoyne } \\
\text { White } \\
\end{array}$ & $\begin{array}{l}\text { Gascoyne } \\
\text { Blue }\end{array}$ & $\begin{array}{l}\text { Gascoyne } \\
\text { Yellow }\end{array}$ \\
\hline \multicolumn{7}{|l|}{ Mineralogy, \% } \\
\hline quartz & 10 & 4 & 19 & 31 & 15 & 20 \\
\hline pyrite & N.D. & 8 & 5 & $<3$ & 5 & 3 \\
\hline anhydrite & $3-7$ & $3-7$ & $3-5$ & $3-7$ & $3-7$ & -- \\
\hline bassanite $^{+}$ & 25 & 25 & 20 & 15 & 15 & $15-25$ \\
\hline kaolinite & $3-10$ & 6 & 6 & 7 & 7 & 8 \\
\hline illite and mixed & & & & & & \\
\hline $\begin{array}{l}\text { layered clays } \\
\text { calcite }\end{array}$ & $\begin{array}{l}3-15 \\
\text { H.D. }\end{array}$ & $\begin{array}{l}<5 \\
\text { N.D. }\end{array}$ & $\begin{array}{l}10 \\
\text { N.D. }\end{array}$ & $\begin{array}{l}10 \\
\text { N.D. }\end{array}$ & $\stackrel{5}{\text { N.D. }}$ & $\begin{array}{l}\text { N.D. } \\
\text { N.D. }\end{array}$ \\
\hline$\%$ LTA & 11.2 & 8.28 & 15.4 & 22.4 & 13.4 & 12.5 \\
\hline
\end{tabular}

Note: Velva, Center, ard Ion-exchanged were not analyzed due to problems interpreting results of the Mineralogy of LTA of lignite coals.

+ - May be an artifact of low-temperature ashing.

* - Estimated value.

e - Analyses performed by the Mineral Constitution Laboratories, the Pennsylvania State University. N.D. - Not detected. 
Table 7. Composition of the ASTH ash - North Ilakota lignites.

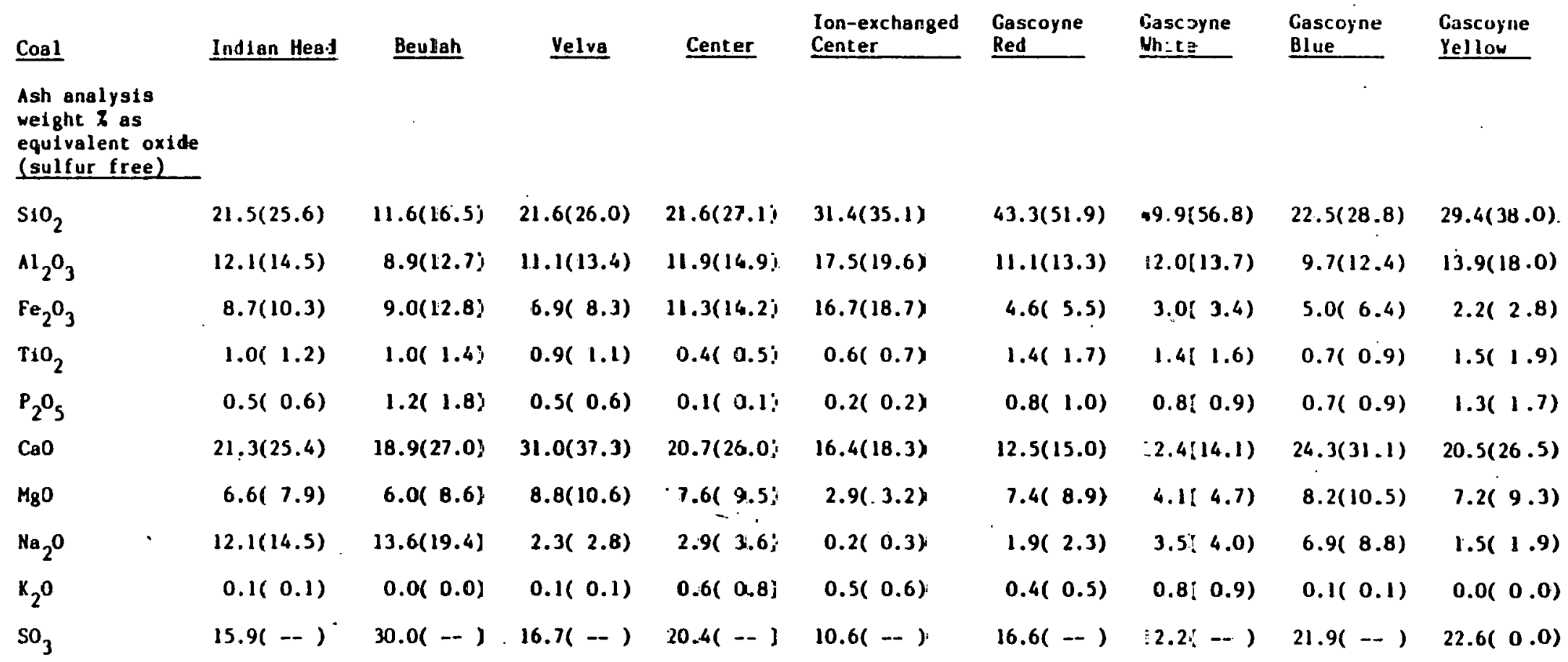


Table 7. Ash fusion results - North Dakota lignites.

\begin{tabular}{|c|c|c|c|c|c|c|c|c|c|}
\hline Coal. & Indian Head & Beulah & Velva & Center & $\begin{array}{l}\text { lon-exchanged } \\
\text { Center }\end{array}$ & $\begin{array}{l}\text { Cascoyne } \\
\text { Red } \\
\end{array}$ & $\begin{array}{l}\text { Gascoine } \\
\text { White } \\
\end{array}$ & $\begin{array}{l}\text { Cascoune } \\
\text { Blue }\end{array}$ & $\begin{array}{l}\text { Gascoyne } \\
\text { Yelloni }\end{array}$ \\
\hline \multicolumn{10}{|l|}{ Reducing Atmosphere, ${ }^{\circ} \mathrm{C}$} \\
\hline $\begin{array}{l}\text { Initial deformation } \\
\text { softening } \\
\text { liemispherical } \\
\text { fluid }\end{array}$ & $\begin{array}{l}1200 \\
1220 \\
1230 \\
1250\end{array}$ & $\begin{array}{l}1290 \\
1350 \\
1360 \\
1370\end{array}$ & $\begin{array}{l}1270 \\
1290 \\
1290 \\
1300\end{array}$ & $\begin{array}{l}1240 \\
1260 \\
1270 \\
1280\end{array}$ & $\begin{array}{l}1110 \\
1170 \\
1220 \\
1280\end{array}$ & $\begin{array}{l}1170 \\
1180 \\
1190 \\
1220\end{array}$ & $\begin{array}{l}1140 \\
1160 \\
1200 \\
1240\end{array}$ & $\begin{array}{l}1010 \\
1160 \\
1180 \\
1200\end{array}$ & $\begin{array}{l}1230 \\
1250 \\
1260 \\
1270\end{array}$ \\
\hline \multicolumn{10}{|l|}{ Oxjdizing Atmosphere, ${ }^{\circ} \mathrm{C}$} \\
\hline $\begin{array}{l}\text { Initial deformation } \\
\text { softening } \\
\text { bemispherical } \\
\text { fluid }\end{array}$ & $\begin{array}{l}1280 \\
1280 \\
1290 \\
1290\end{array}$ & $\begin{array}{l}1310 \\
1340 \\
1340 \\
1380\end{array}$ & $\begin{array}{l}1300 \\
1310 \\
1320 \\
1340\end{array}$ & $\begin{array}{l}1270 \\
1270 \\
1280 \\
1280\end{array}$ & $\begin{array}{l}1250 \\
1270 \\
1310 \\
1350\end{array}$ & $\begin{array}{l}1180 \\
1190 \\
1220 \\
1230\end{array}$ & $\begin{array}{l}1150 \\
1170 \\
1230 \\
1260\end{array}$ & $\begin{array}{l}1060 \\
1180 \\
1190 \\
1210\end{array}$ & $\begin{array}{l}1260 \\
1270 \\
1270 \\
1280\end{array}$ \\
\hline
\end{tabular}


Table :8. Mineralogy of low-temperature ash - subbituminous ${ }^{e}$.

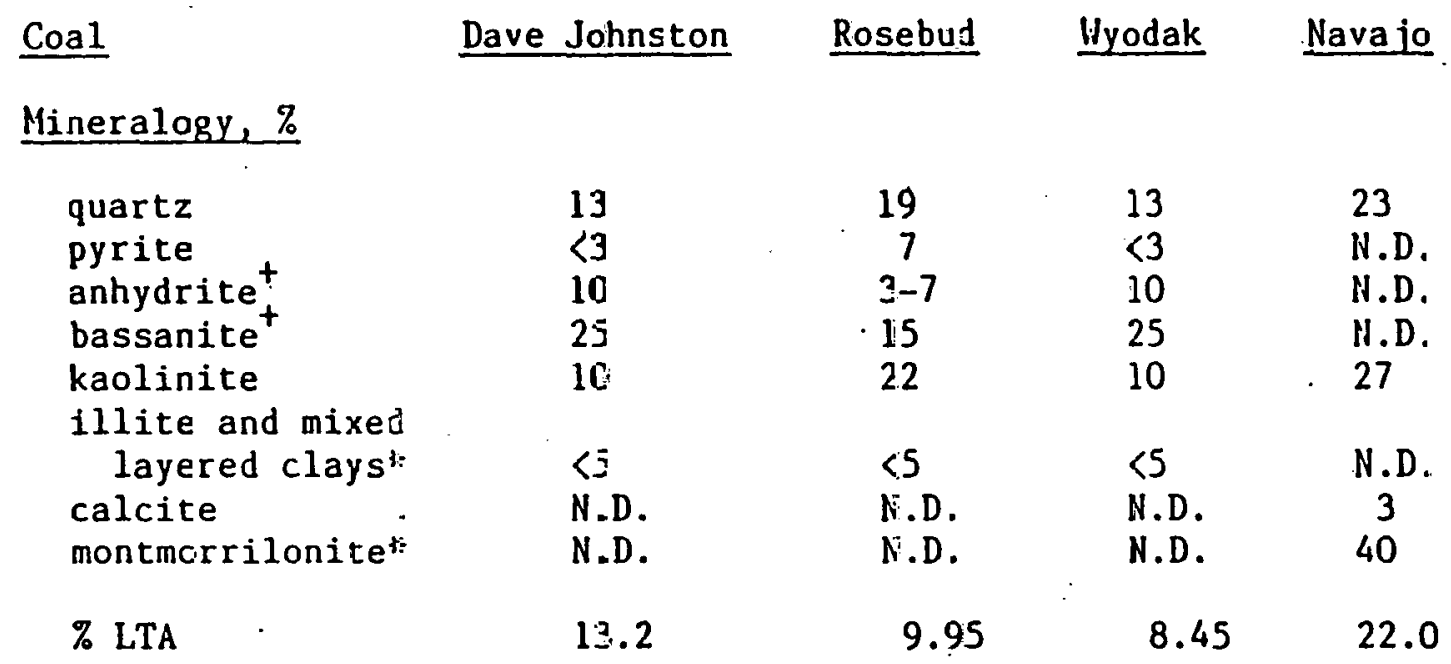

Note: Hineralogy of LTA of Rosebud floct/sink samples was not determined.

+ - May be an art:-fact of 1ow-temperature ashirig.

* - Estimated value.

(e. - Analyses performed by the Mineral Constitution Laboratories, The Perinsylvania State University. N.D. - Hot detected. 
Table 8. Composition of the ASTY ași - subbituminous.

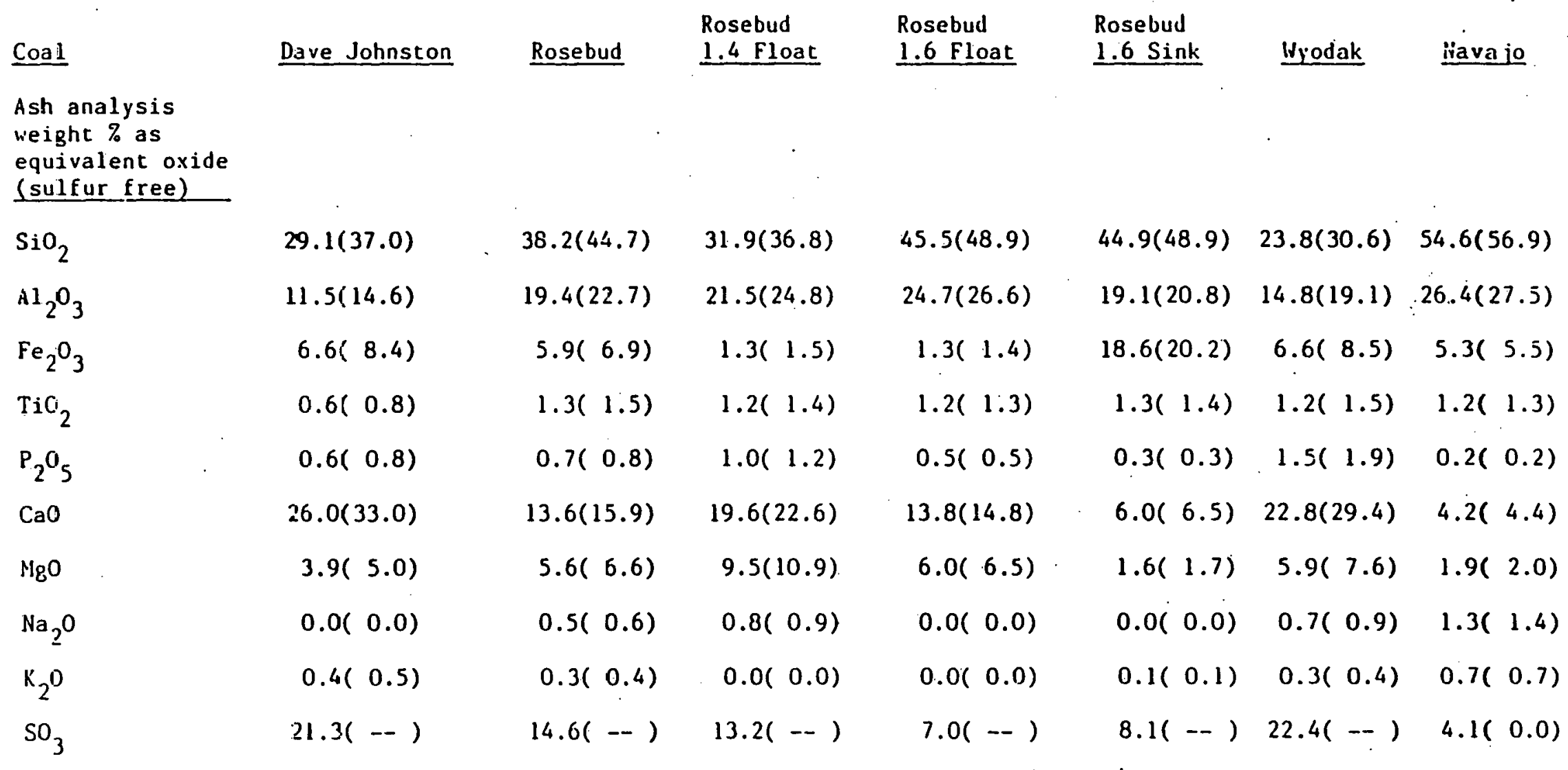


Table 8. Ash fusion results - subbitumincus.

\begin{tabular}{|c|c|c|c|c|c|c|c|}
\hline Coal & Dave Johnston & Rosebud & $\begin{array}{l}\text { Rosebud } \\
1.4 \text { Float }\end{array}$ & $\begin{array}{l}\text { Rosebud } \\
1.6 \text { Floar }\end{array}$ & $\begin{array}{l}\text { Rosebud } \\
1.6 \text { Sink }\end{array}$ & Wyodak & Nava jo \\
\hline \multicolumn{8}{|l|}{ Reducing Atmosphere, ${ }^{\circ} \mathrm{C}$} \\
\hline $\begin{array}{l}\text { initial deformation } \\
\text { softening } \\
\text { hemispherical } \\
\text { fluid }\end{array}$ & $\begin{array}{l}1170 \\
1190 \\
1210 \\
1220\end{array}$ & $\begin{array}{l}1210 \\
1240 \\
1310 \\
1330\end{array}$ & $\begin{array}{l}1180 \\
1200 \\
1340 \\
1390\end{array}$ & $\begin{array}{l}1250 \\
1310 \\
1330 \\
1370\end{array}$ & $\begin{array}{l}1210 \\
1240 \\
1250 \\
1260\end{array}$ & $\begin{array}{l}1170 \\
1190 \\
1210 \\
1220\end{array}$ & $\begin{array}{l}1430 \\
1490 \\
1500 \\
1530\end{array}$ \\
\hline Oxidizing Atmosphere, ${ }^{c} \mathrm{C}$ & & & & & & & \\
\hline $\begin{array}{l}\text { initial deformation } \\
\text { softening } \\
\text { hemispherical } \\
\text { fluid }\end{array}$ & $\begin{array}{l}1210 \\
1210 \\
1220 \\
1240\end{array}$ & $\begin{array}{l}1230 \\
1260 \\
1340 \\
1360\end{array}$ & $\begin{array}{l}1200 \\
1220 \\
1360 \\
1410\end{array}$ & $\begin{array}{l}1285 \\
1333 \\
1343 \\
1393\end{array}$ & $\begin{array}{l}1230 \\
1260 \\
1270 \\
1270\end{array}$ & $\begin{array}{l}1200 \\
1210 \\
1250 \\
1280\end{array}$ & $\begin{array}{l}1440 \\
1500 \\
1510 \\
1540\end{array}$ \\
\hline
\end{tabular}


Table 9. Composition of ASTM ash - Texas lignites.

\begin{tabular}{|c|c|c|c|}
\hline Coa1 & San Miguel & $\begin{array}{l}\text { Ion-exchanged } \\
\text { San Miguel }\end{array}$ & Hartin Lake \\
\hline $\begin{array}{l}\text { Ash analysis } \\
\text { weight } \% \text { as } \\
\text { equivalent oxide } \\
\text { (sulfur free) }\end{array}$ & $\cdot$ & & \\
\hline $\mathrm{SiO}_{2}$ & $52.8(59.3)$ & $70.4(72.3)$ & $19.9(26.1)$ \\
\hline $\mathrm{Al}_{2} \mathrm{O}_{3}$ & $14.6(16.4)$ & $17.1(17.6)$ & $11.9(15.6)$ \\
\hline $\mathrm{F} \in{ }_{2} \mathrm{O}_{3}$ & $4.8(5.3)$ & $5.5(5.6)$ & $16.1(21.0)$ \\
\hline $\mathrm{TiO}_{2}$ & $0.8(0.9)$ & $0.8(0.8)$ & $0.9(1.1)$ \\
\hline $\mathrm{P}_{2} \mathrm{O}_{5}$ & $0.3(0.4)$ & $0.1(0.1)$ & $0.7(0.9)$ \\
\hline $\mathrm{CaO}$ & $7.9(8.8)$ & $2.6(2.7)$ & $16.2(21.1)$ \\
\hline $\mathrm{MgO}$ & $0.8(0.9)$ & $0.3(0.3)$ & $7.5(9.7)$ \\
\hline $\mathrm{Na}_{2} \mathrm{O}$ & $4.8(\cdot 5.3)$ & $0.1(0.1)$ & $3.2(4.2)$ \\
\hline $\mathrm{K}_{2} \mathrm{O}$ & $2.4(2.7)$ & $0.5(0.5)$ & $0.3(0.4)$ \\
\hline $\mathrm{SO}_{3}$ & $10.9(--)$ & $2.4(--)$ & $23.5(--)$ \\
\hline
\end{tabular}


Table 9. Ash fusion results - Texas lignite.

Coal Ion-exchanged

Reducing Atmosphere, ${ }^{\circ} \mathrm{C}$

initial deformation
softening
hemispherical
fluid

1180

1260

1250

1200

1300

1270

$\overline{1370}$

1320

1280

1390

1280

Oxidizing Atmosphere, ${ }^{\circ} \mathrm{C}$

initial deformactun

1200

12.50

1240

1260

1280

soltening

1390

1380

fluid

1400

1410

1300

1300

1310 
CHEMICAL FRACTIONATION DATA

Table 10. Concentration of inorganic elements in North Dakota lignites on a dry coal basis (parts per million).

\begin{tabular}{|c|c|c|c|c|c|c|c|c|}
\hline & $\begin{array}{l}\text { Indian } \\
\text { Head }\end{array}$ & Beulah & Velva & $\begin{array}{l}\text { Center } \\
\text { Center } \\
\end{array}$ & $\begin{array}{l}\text { Gascoyne } \\
\text { Red } \\
\end{array}$ & $\begin{array}{l}\text { Gascoyne } \\
\text { White } \\
\end{array}$ & $\begin{array}{l}\text { Gascoyne } \\
\text { Blue }\end{array}$ & $\begin{array}{l}\text { Gascoyne } \\
\text { Yellow }\end{array}$ \\
\hline $\mathrm{Na}$ & 6221 & 4620 & N.D. & 3180 & 1243 & 4730 & 5000 & 720 \\
\hline Mg & 9690 & 980 & & 7910. & 4970 & 5010 & 4870 & 5060 \\
\hline$A 1$ & 4940 & 2880 & & 5580 & 5240 & 11480 & 8140 & 8870 \\
\hline Si & 7060 & 7760 & & 11540 & 13690 & 33060 & 12550 & 15190 \\
\hline$k$ & 1150 & -- & & 1340 & 390 & 1530 & 680 & 200 \\
\hline $\mathrm{Ca}$ & 15560 & 7770 & & 13630 & 17400 & 14070 & 19550 & 33670 \\
\hline$\grave{T i}$ & 400 & 104 & & 330 & 430 & 1060 & $\cdot 370$ & 500 \\
\hline $\mathrm{Fe}$ & 6810 & 4800 & & 9640 & 5300 & 2810 & 3420 & 4340 \\
\hline
\end{tabular}

N.D. - No Data 
Table 11. Percentage of the element associated in the North Dakota lignites as a cation extractable with 1 M ammonium acetare.

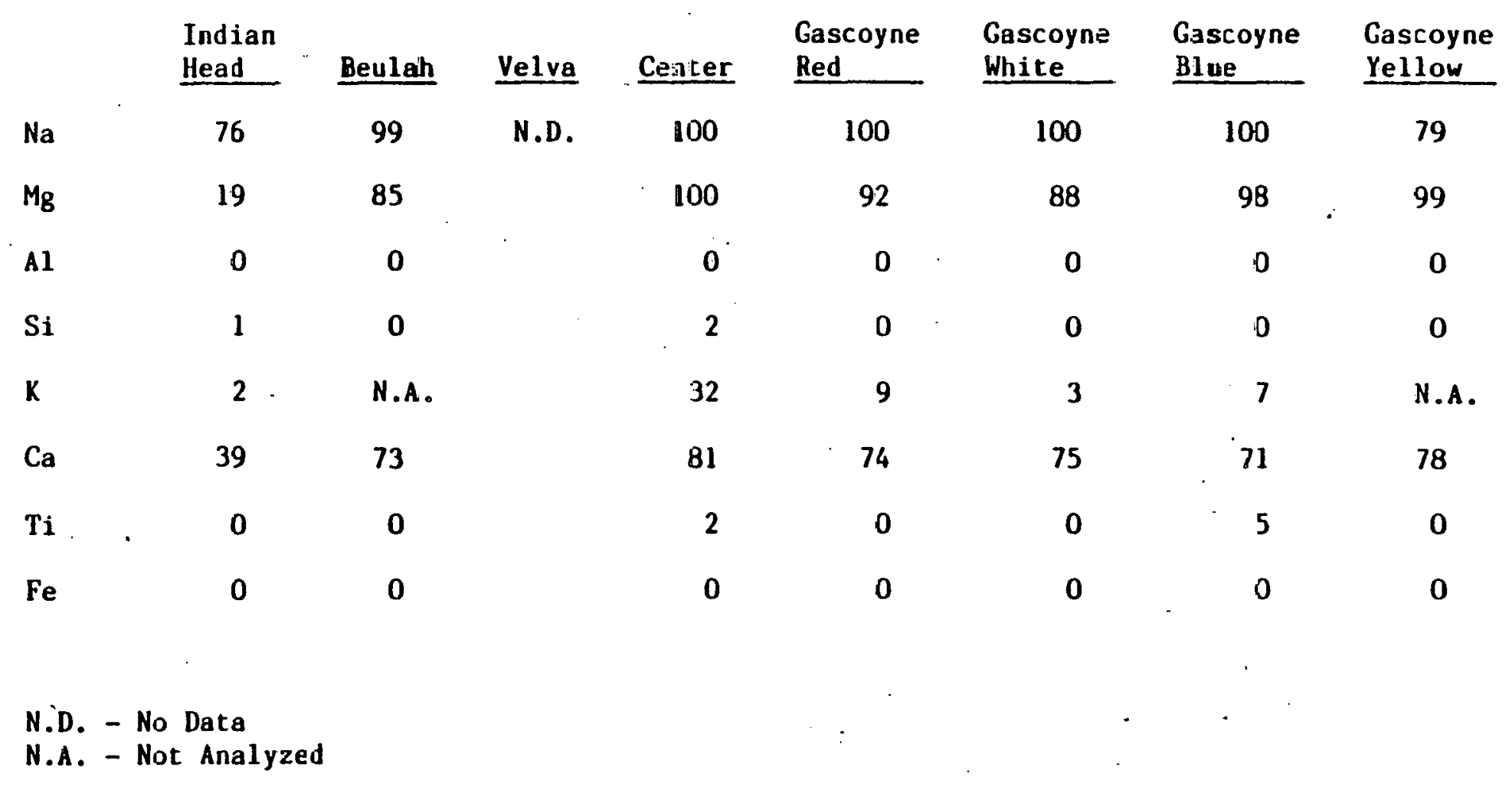


Table 12. Percentage of the element associated in the North Dakota lignites possibly as a coordinated species, carbonate, or hydroxide that is extractable with $1 \mathrm{M} \mathrm{HCl}$.

\begin{tabular}{|c|c|c|c|c|c|c|c|c|}
\hline & $\begin{array}{l}\text { Indian } \\
\text { Head }\end{array}$ & Beulah & Velva & Center & $\begin{array}{l}\text { Gascoyne } \\
\text { Red }\end{array}$ & $\begin{array}{l}\text { Gascoyne } \\
\text { White } \\
\end{array}$ & $\begin{array}{l}\text { Gascoyne } \\
\text { Blue }\end{array}$ & $\begin{array}{l}\text { Gascoyne } \\
\text { Yellow }\end{array}$ \\
\hline $\mathrm{Na}$ & 0 & 0 & N.D. & 0 & 1 & 0 & 0 & 8 \\
\hline$M_{8}$ & 1 & 15 & & 0 & 4 & 5 & 2 & 3 \\
\hline $\mathrm{Al}$ & 51 & 80 & & 53 & 52 & 31 & 32 & 50 \\
\hline $\mathrm{Si}$ & 14 & 6 & & 11 & 2 & 2 & 0 & 8 \\
\hline K & 1 & N.A. & & 25 & 0 & 0 & 0 & N.A. \\
\hline $\mathrm{Ca}$ & 12 & 18 & & 16 & 14 & 24 & 29 & 17 \\
\hline $\mathbf{T i}$ & 2 & 10 & & 26 & 29 & 8 & 16 & 8 \\
\hline $\mathrm{Fe}$ & 40 & 45 & & 29 & 38 & 29 & 32 & 24 \\
\hline
\end{tabular}


Table 13. Percentage of the element remaining in the North Dakota lignites after extraction with ammonium acetate and hydrochloric acid. These elements are probably associated within the coal matrix as insoluble clay minerals, quartz, and sulfides.

\begin{tabular}{|c|c|c|c|c|c|c|c|}
\hline $\begin{array}{l}\text { Indian } \\
\text { Head }\end{array}$ & Beulah & Velva & Center & $\begin{array}{l}\text { Gascoyne } \\
\text { Red } \\
\end{array}$ & $\begin{array}{l}\text { Gascoyne } \\
\text { White } \\
\end{array}$ & $\begin{array}{l}\text { Gascayrie } \\
\text { Blue }\end{array}$ & $\begin{array}{l}\text { Gascoyne } \\
\text { Yellow }\end{array}$ \\
\hline 24 & 0 & N.D. & 0 & 0 & 0 & 0 & 13 \\
\hline 80 & 0 & & D & 0 & 7 & D & 0 \\
\hline 49 & 19 & & 47 & 48 & 69 & $6: 3$ & 50 \\
\hline 85 & 94 & & 87 & 98 & 98 & $101]$ & 92 \\
\hline 97 & H.A. & & 43 & 91 & 97 & 93 & N.A. \\
\hline 49 & 8 & & 3 & 12 & 1 & D & 4 \\
\hline 98 & 89 & & 72 & 90 & 98 & 79 & 92 \\
\hline 60 & 55 & & 71 & 62 & 71 & 68 & 76 \\
\hline
\end{tabular}

N.D. - No Data

N.A. - Not Analyzed 
Table 14. Concentration of elements in subbituminous coals and Texas lignites (parts per million).

\begin{tabular}{|c|c|c|c|c|c|c|}
\hline & $\begin{array}{l}\text { Dave } \\
\text { Johnston }\end{array}$ & Rosebud & Wyodak & Nava jo & $\begin{array}{l}\text { San } \\
\text { Miguel }\end{array}$ & $\begin{array}{l}\text { Martin } \\
\text { Lake }\end{array}$ \\
\hline $\mathrm{Na}$ & N.D. & N.A. & N.D. & 2500 & 7300 & 964 \\
\hline Mg & & 4500 & & 970 & 600 & 11510 \\
\hline A1 & & 7940 & & 26000 & 14400 & 4630 \\
\hline Si & & 14330 & & 38000 & 35800 & 7920 \\
\hline K & & N.A. & & 960 & 970 & 993 \\
\hline $\mathrm{Ca}$ & & 10660 & & 3000 & 8210 & 15530 \\
\hline $\mathrm{Ti}$ & & 581 & & 950 & 530 & 203 \\
\hline $\mathbf{F e}$ & & 3090 & & 4500 & 4400 & 11090 \\
\hline
\end{tabular}


Table 15. Percentage of the element in the subbituminous coals and Texas lignites associated as cations extractatile with $1 \mathrm{M}$ ammonium acetate.

\begin{tabular}{|c|c|c|c|c|c|c|}
\hline & $\begin{array}{l}\text { Dave } \\
\text { Johnston }\end{array}$ & Rosetud & Wyodak & Navajo & $\begin{array}{l}\text { San } \\
\text { Migue1 }\end{array}$ & $\begin{array}{l}\text { Martin } \\
\text { Lake }\end{array}$ \\
\hline $\mathrm{Na}$ & N.D. & N.A. & N.D. & 82 & 100 & 98 \\
\hline $\mathrm{Mg}$ & & 100 & & 31 & 100 & 17 \\
\hline $\mathrm{Al}$ & & 0 & & 0 & 0 & 0 \\
\hline Si & & 0 & & 0 & 0 & 0 \\
\hline K & & N.A. & & 6 & 53 & 2 \\
\hline $\mathrm{Ca}$ & . & 83 & & 72 & 71 & 52 \\
\hline $\mathrm{Ti}$ & & 0 & & 0 & 0 & 0 \\
\hline $\mathrm{Fe}$ & & 0 & & 0 & 0 & 28 \\
\hline
\end{tabular}

N.D. - No Data

N.A. - Not Ánalyzed 
Table 16. Percentage of the elements in the subbituminous coals and Texas lignites possibly associated as coordinated species, carbonates, or hydroxides that are extractable with hydrochloric acid.

\begin{tabular}{|c|c|c|c|c|c|c|}
\hline & $\begin{array}{l}\text { Dave } \\
\text { Johnston }\end{array}$ & Rosebud & Wyodak & Nava jo & $\begin{array}{l}\text { San } \\
\text { Miguel }\end{array}$ & $\begin{array}{l}\text { Martin } \\
\text { Lake }\end{array}$ \\
\hline $\mathrm{Na}$ & N.D. & N.A. & N.D. & 3 & 0 & 2 \\
\hline $\mathrm{Mg}$ & & 0 & & 44 & 0 & 1 \\
\hline$A 1$ & & 29 & & 13 & 11 & 54 \\
\hline $\mathrm{Si}$ & & 6 & & 10 & 0 & 12 \\
\hline$K$ & & N.A. & & 9 & 9 & 2 \\
\hline $\mathrm{Ca}$ & & 15 & & 21 & 27 & 21 \\
\hline $\mathrm{Ti}$ & - & 27 & & 2 & 15 & 2 \\
\hline $\mathrm{Fe}$ & & 14 & & 68 & 41 & 21 \\
\hline
\end{tabular}

N.D. - No Data

N.A. - Not Analyzed 
Table 17. Percentage of the element remaining in the subbituminous coals and Texas lignites after extraction with ammonium acetate and hidrochloric acid. These elements are probably associated within the coal matrix as insoluble ciay minerals, quartz, and sulfides.

\begin{tabular}{|c|c|c|c|c|c|c|}
\hline & $\begin{array}{l}\text { Dave } \\
\text { Johnston }\end{array}$ & Rosebud & Wyodak & Narajo & $\begin{array}{l}\text { San } \\
\text { Migue I }\end{array}$ & $\begin{array}{l}\text { Martin } \\
\text { Lake }\end{array}$ \\
\hline $\mathrm{Na}$ & N.D. & N.A. & N.D. & 15 & 0 & 0 \\
\hline $\mathrm{Mg}$ & & 0 & & 25 & 0 & 82 \\
\hline $\mathrm{A} 1$ & & 71 & & 87 & 88 & 46 \\
\hline $\mathbf{S i}$ & & 94 & & 9i] & 100 & 88 \\
\hline$k$ & & N.A. & & 85 & 38 & 96 \\
\hline $\mathrm{Ca}$ & & 2 & & 7 & 2 & 27 \\
\hline $\mathbf{T} \mathbf{i}$ & & 73 & & 93 & 85 & 98 \\
\hline $\mathrm{Fe}$ & & 86 & & 32 & 59 & 79 \\
\hline
\end{tabular}

N.D. - No Data

N.A. - Not Analyzed 


\section{CHARACTERISTICS OF DEPOSITS PRODUCED IN A LABORATORY FURNACE}

The general structure of a deposit consists of four distinct regions :

1. Dust, which typically consists of fine spheres (mainly 2 - 5 microns) covering the substrate surface but which could not be easily blown from the surface.

2. The lower portion of the deposit mass, which consists mainly of 10 - 15 micron spheres loosely sintered together, with substantial porosity.

3. The upper portion of the deposit mass, consisting of 2550 micron spheres which were definitely fused together and which had less porosity than the lower portion of the deposit.

4. The top portion of the deposit, in which the material appears to be almost completely fused, with evidence of crystallization from a melt.

Each of these regions will be discussed in detail in the subsections which follow.

The general structures of the deposits obtained from the Suite 1 coals are compared in Table 18. The results of analysis of selected regions of these deposits are summarized in Table 19. The $\mathrm{Fe}_{2} \mathrm{O}_{3}$ content of the deposits from all the high-rank coals except Upper Hiawatha \#1 was higher than that in the ASTM ash. 
Table 18. Comparison of structure of deposits.

\begin{tabular}{|c|c|c|c|c|}
\hline Coal & Dust material & $\begin{array}{l}\text { Lower portion } \\
\text { of deposit mass }\end{array}$ & $\begin{array}{l}\text { Upper portion } \\
\text { of deposit mass }\end{array}$ & $\begin{array}{l}\text { Top of deposit } \\
\text { mass }\end{array}$ \\
\hline $\begin{array}{l}\text { Illinots } \# 6 \\
\text { U.Hlawatha } \# 1 \\
\text { U.Freeport } \\
\text { Texas }\end{array}$ & $\begin{array}{l}\text { Weak, no sintering, } \\
\text { no fuston. }\end{array}$ & $\begin{array}{l}\text { Weak, slightly } \\
\text { sintered, no } \\
\text { fuston. }\end{array}$ & $\begin{array}{l}\text { Strong, highly } \\
\text { sintered, no } \\
\text { fustor. }\end{array}$ & $\begin{array}{l}\text { Very strong, } \\
\text { fused. }\end{array}$ \\
\hline $\begin{array}{l}\text { Powder River- } \\
\text { BasIn } \\
\text { N.Dakota }\end{array}$ & $\begin{array}{l}\text { Weak, no sintering, } \\
\text { no fusion, but } \\
\text { sticky. }\end{array}$ & Sane as above. & $\begin{array}{l}\text { Strong, moderated } \\
\text { sintering, no } \\
\text { fustar. }\end{array}$ & $\begin{array}{l}\text { Strong, } \\
\text { fused. }\end{array}$ \\
\hline $\begin{array}{l}\text { Tunnelton } \\
\text { Pittsburgh } \Downarrow 8\end{array}$ & $\begin{array}{l}\text { Weak, no sintering, } \\
\text { no fusion. }\end{array}$ & Sane as above. & $\begin{array}{l}\text { Less strong than } \\
\text { above; moderated } \\
\text { sintering, no } \\
\text { fusicn: }\end{array}$ & $\begin{array}{l}\text { Strong, highly } \\
\text { sintered, } \\
\text { fused. }\end{array}$ \\
\hline
\end{tabular}


Table 19. Spectrochemical analysis of high temperature ash (ASTM) and deposit from Upper Freeport coal.

$$
\begin{array}{cll}
\text { High temperature } & \text { Dust material and Upper portion } \\
\text { ash } & \begin{array}{l}
\text { lower portion of } \\
\text { deposit mass }
\end{array}
\end{array}
$$

Weight percent of equivalent oxides $\left(\mathrm{SO}_{3}\right.$ free basis)

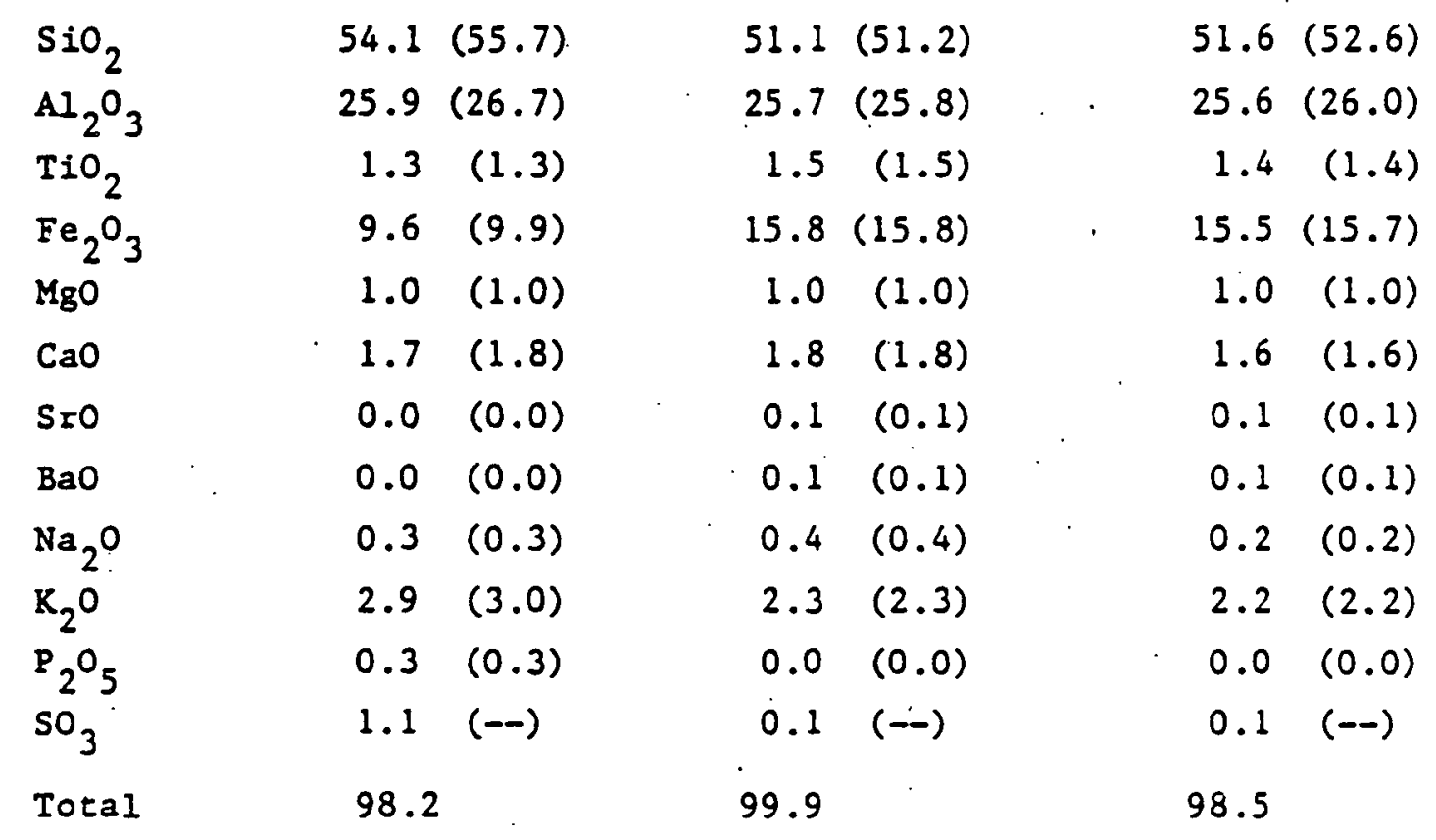

* Source = Mineral Constitution Laboratories, The Pennsylvania State University, Pa. 
Table 19. Spectrochenical analysis of high temperature ash (ASTM) from Illinois $\# 6$ coal.

High temperature ash Upper portion of deposit mass

Weight percent of equivalent oxides $\left(\mathrm{SO}_{3}\right.$ free basis).

\begin{tabular}{|c|c|c|c|}
\hline $\mathrm{SiO}_{2}$ & $48.3(50.6)$ & 52.1 & $(52.1)$ \\
\hline $\mathrm{Al}_{2} \mathrm{O}_{3}$ & $17.5(18.3)$ & 18.9 & $(18.9)$ \\
\hline $\mathrm{I}_{\mathrm{N}} \mathrm{n}_{2}$ & $0.8((0.8)$ & 0.8 & $(0.8)$ \\
\hline $\mathrm{Fe}_{2} \mathrm{O}_{3}$ & $20.9(21.9)$ & 21.3 & $(21.3)$ \\
\hline $\mathrm{MgO}$ & $0.8 \quad(0.9)$ & 1.0 & $(1.0)$ \\
\hline $\mathrm{CaO}$ & $4.7 \quad(4.9)$ & 4.0 & $(4.0)$ \\
\hline $\mathrm{Na}_{2} \mathrm{O}$ & $0.6 \quad(0.6)$ & 0.5 & $(0.5)$ \\
\hline $\mathrm{K}_{2} \mathrm{O}$ & $1.6(1.7)$ & 1.6 & $(1.6)$ \\
\hline $\mathrm{P}_{2} \mathrm{O}_{5}$ & $0.2 \cdot(0.2)$ & 0.0 & $(0.0)$ \\
\hline $\mathrm{SO}_{3}$ & $4.6 \quad(-)$ & 0.1 & $(-\infty)$ \\
\hline Toral & 101.1 & 100.3 & \\
\hline
\end{tabular}

*Source = Mineral Congtitution Laboratories, The Pennsylivania State UnIversity, Pa. 
Table 19. Spectrochemical analysis of high temperature ash (ASTM) from Tunnelton coal.

High temperature ash Upper portion of deposit mass Weight percent of equivalent oxides ( $\mathrm{SO}_{3}$ free basis)

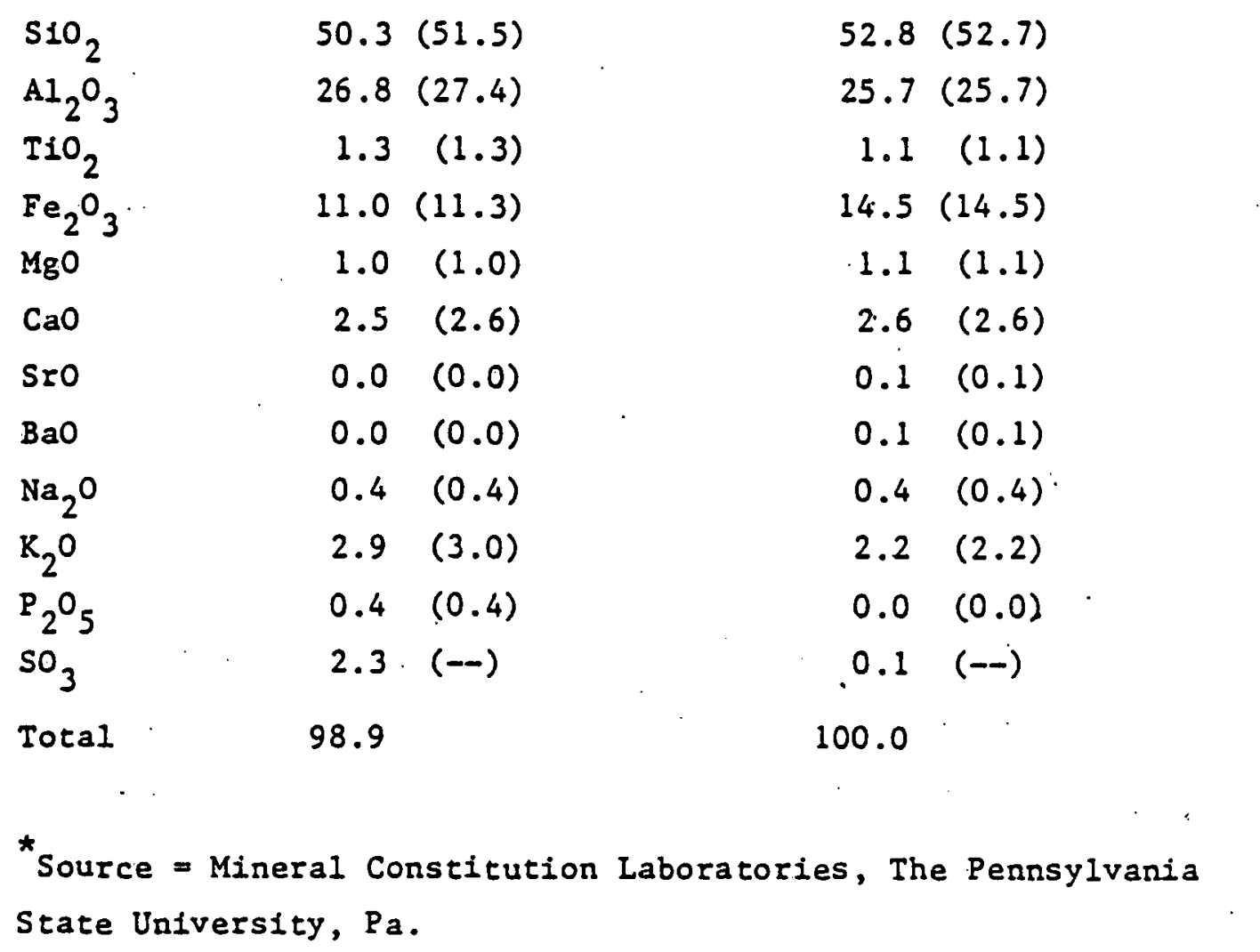


Table 19. Spectrochemical anlysis of high temperature ash (ASTM) from P1ttsburgh \#8 coal.

High temperature ash Upper portion of deposit mass Weight percent of equivalent oxides $\left(\mathrm{SO}_{3}\right.$ free basis)

\begin{tabular}{|c|c|c|}
\hline $\mathrm{SiO}_{2}$ & $51.1(51.5)$ & $45.7(45.7)$ \\
\hline $\mathrm{Al}_{2} \mathrm{O}_{3}$ & $26.9(27.0)$ & $23.5(23.5)$ \\
\hline $\mathrm{T}_{2} \mathrm{O}_{2}$ & $0.9 \quad(0.9)$ & $1.0 \quad(1.0)$ \\
\hline $\mathrm{Fe}_{2} \mathrm{u}_{3}$ & $15.2(15.3)$ & $18.6(18.6)$ \\
\hline $\mathrm{MgO}$ & $0.6(0.6)$ & $0.3 \quad(0.7)$ \\
\hline láo & $0.9 \quad(0.9)$ & $1.2(1.2)$ \\
\hline Sro & $0.0 \quad(0.0)$ & $0.1 \quad(0.1)$ \\
\hline $\mathrm{BaO}$ & $0.0 \quad(0.0)$ & $0.1 \quad(0.1)$ \\
\hline $\mathrm{Na}_{2} \mathrm{O}$ & $0.2 \quad(0.2)$ & $0.3 \quad(0.3)$ \\
\hline $\mathrm{K}_{2} \mathrm{O}$ & $2.2 \quad(2.2)$ & $1.7 \quad(1.7)$ \\
\hline $\mathrm{P}_{2} \mathrm{O}_{5}$ & $0.1 \quad(0.1)$ & $0.0 \quad(0.0)$ \\
\hline $\mathrm{SO}_{3}$ & $0.7 \quad(-)$ & $0.1 \quad(-)$ \\
\hline Total & 99.1 & 93.0 \\
\hline
\end{tabular}


Table 19. Spectrochemical analysis of high temperature ash (ASTM) from Upper Hiawatha \#1 coal*

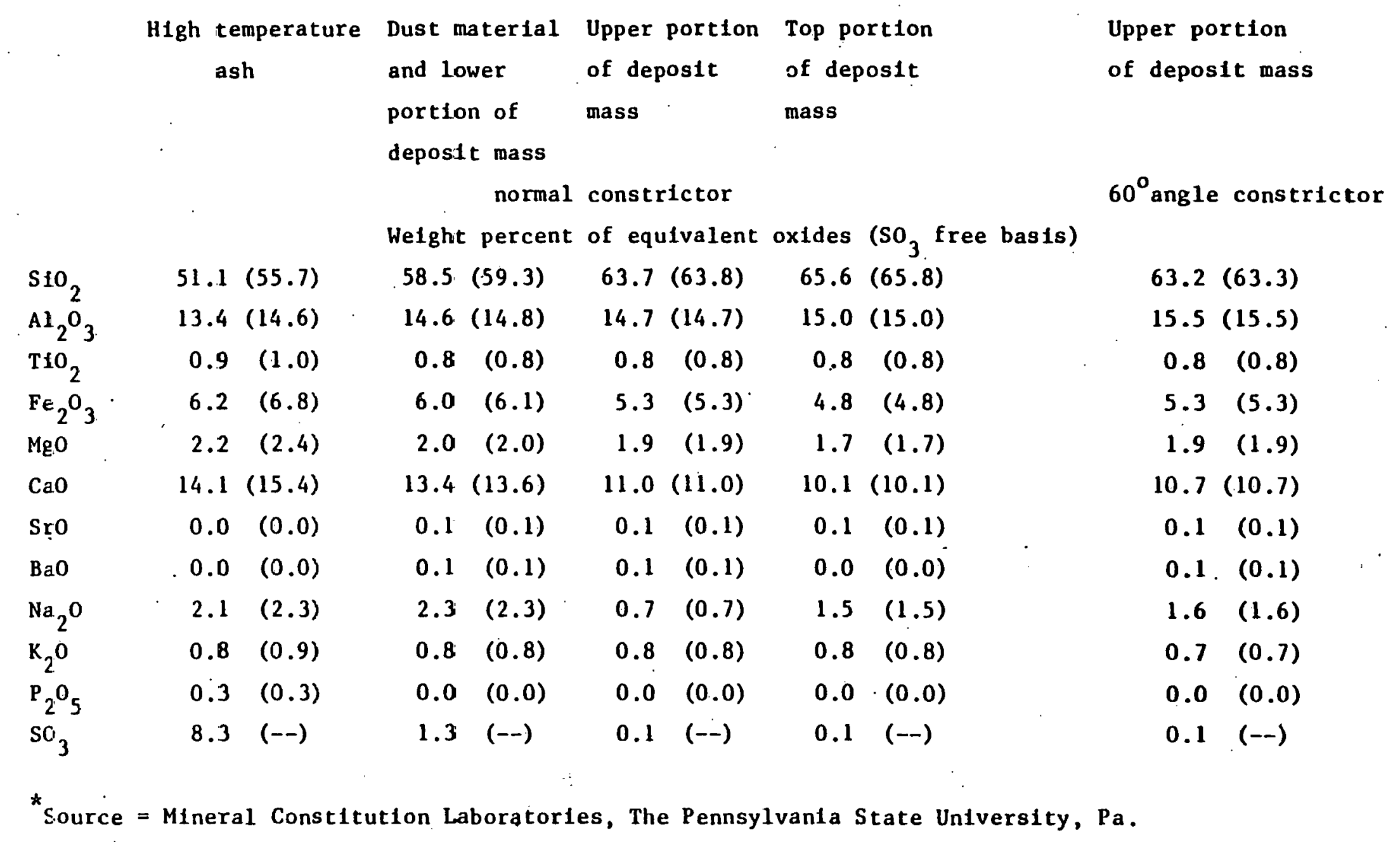


Table's19. Spectrochemical analysis of high temperature ash (ASTM) from North Dakota Iignite.

$\begin{array}{cll}\text { High temperature } & \text { Upper portion } & \text { Upper portion } \\ \text { ash } & \text { of deposit mass } & \text { of deposit mass } \\ & \text { (normal } & \left(60^{\circ} \text { angle }\right. \\ & \text { constrictor) } & \text { constrictor) }\end{array}$

Welght percent of equivalent oxides $\left(\mathrm{SO}_{3}\right.$ free basis)

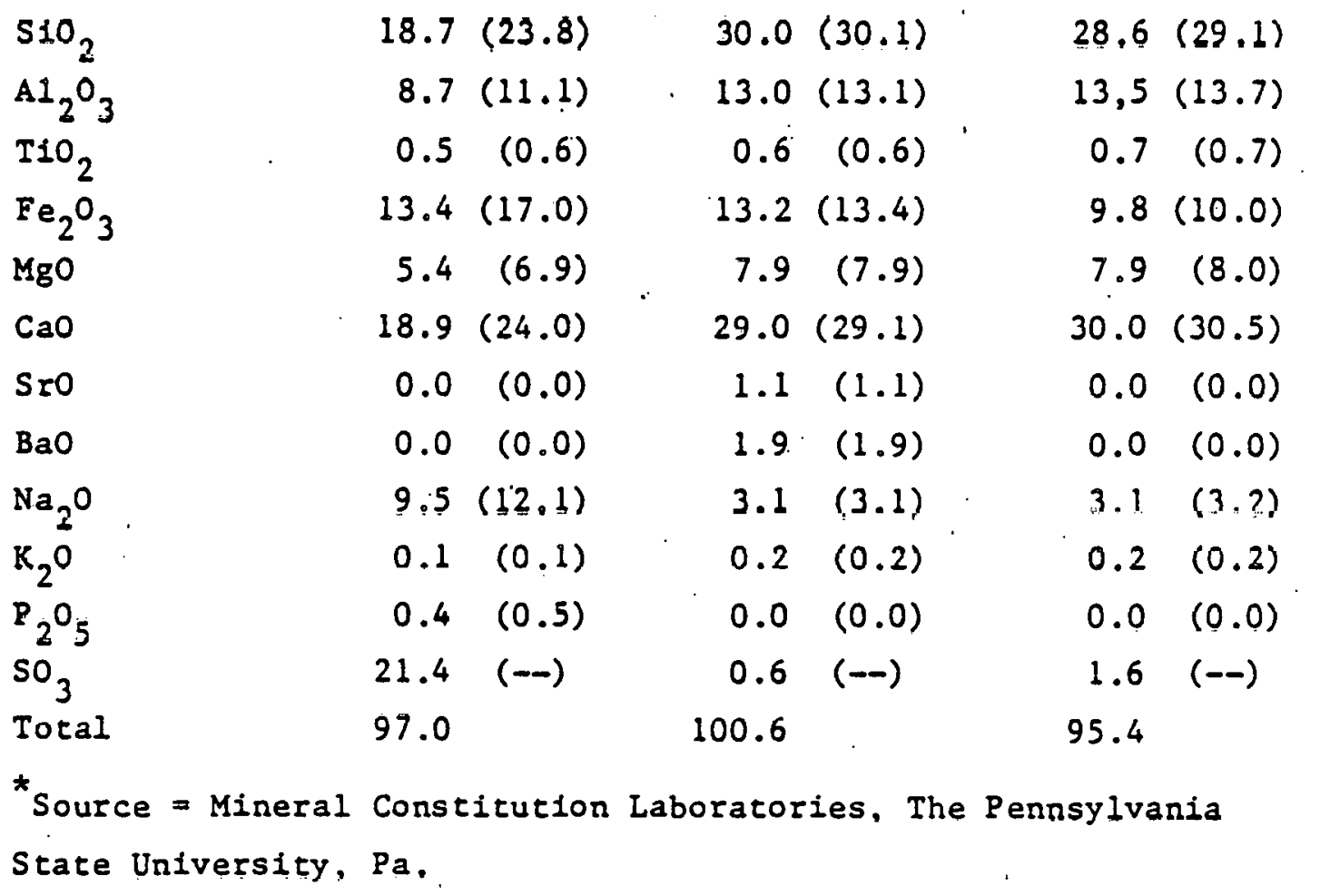


Table 19. Spectrochemical, analysis of high temperature ash (ASTM) from Texas 1ignite*.

$\begin{array}{llll}\text { High temperature } & \text { Dust meterial Upper portion } & \text { Top portion } \\ \text { ash } & \text { and lower } & \text { of deposit } & \text { of deposit } \\ & \text { portion of } & \text { mass } & \text { mass } \\ & \text { deposit mass } & & \end{array}$

Weight percent of equivalent oxides ( $\mathrm{SO}_{3}$ free basis)

$\begin{array}{lrrrrrrrr}\mathrm{SiO}_{2} & 48.7 & (55.0) & 49.7 & (50.0) & 57.7 & (57.8) & 58.3 & (58.4) \\ \mathrm{Al}_{2} \mathrm{O}_{3} & 18.6 & (21.0) & 21.5 & (21.7) & 22.5 & (22.5) & 23.4 & (23.4) \\ \mathrm{IIO}_{2} & 1.2 & (1.4) & 1.8 & (1.8) & 1.7 & (1.7) & 1.7 & (1.7) \\ \mathrm{Fe}_{2} \mathrm{O}_{3} & 5.6 & (6.3) & 4.2 & (4.2) & 3.4 & (3.4) & 3.5 & (3.5) \\ \mathrm{MgO} & 2.1 & (2.3) & 3.4 & (3.4) & 2.3 & (2.3) & 2.3 & (2.3) \\ \mathrm{CaO} & 9.1 & (10.3) & 16.5 & (16.6) & 10.7 & (10.7) & 9.8 & (9.8) \\ \mathrm{SrO} & 0.0 & (0.0) & 0.2 & (0.2) & 0.2 & (0.2) & 0.2 & (0.2) \\ \mathrm{BaO} & 0.0 & (0.0) & 0.2 & (0.2) & 0.1 & (0.1) & 0.1 & (0.1) \\ \mathrm{Na}_{2} \mathrm{O} & 0.3 & (0.3) & 0.9 & (0.9) & 0.4 & (0.4) & 0.4 & (0.4) \\ \mathrm{K}_{2} \mathrm{O} & 0.9 & (1.0) & 0.5 & (0.5) & 0.7 & (0.7) & 0.7 & (0.7) \\ \mathrm{P}_{2} \mathrm{O}_{5} & 0.1 & (0.1) & 0.0 & (0.0) & 0.0 & (0.0) & 0.0 & (0.0) \\ \mathrm{SO}_{3} & 11.4 & (--) & 0.7 & (--) & 0.2 & (--) & 0.1 & (--) \\ \mathrm{Total}_{3} & 98.0 & & 99.7 & & 99.8 & & 100.5 & \end{array}$

\footnotetext{
*Source - Mineral Constitution Laboratories, The Pennsylvania State University, Pa.
} 
Table 19. Spectrochemical analysis of high temperature ash (ASTM) from Powder River Basin Coal.

$\begin{array}{llll}\text { High } & \text { Dust material Upper portion } & \text { Upper portion } \\ \text { temperature } & \text { and lower } & \text { of deposit } & \text { of deposit } \\ \text { ash } & \text { portion of } & \text { mass } & \text { mass } \\ & \text { deposit mass } & \text { (normal } & \left(60^{\circ} \text { angle }\right. \\ & & \text { constrictor) } & \text { constrictor) } \\ & & & \end{array}$

\begin{tabular}{|c|c|c|c|c|c|c|c|c|}
\hline $\mathrm{SiO}_{2}$ & 25.8 & $(31.5)$ & 20.4 & $(20.8)$ & 36.0 & $(36.1)$ & $27 . j$ & $(28.0)$ \\
\hline $\mathrm{Al}_{2} \mathrm{O}_{3}$ & 15.1 & $(18.5)$ & 17.8 & $(18.2)$ & 19.2 & $(19.2)$ & 18.8 & $(19.0)$ \\
\hline $\mathrm{TiO}_{2}$ & 0.8 & $(1.0)$ & 1.0 & $(! .0)$ & 1.0 & $(1.0)$ & 1.0 & $(1.0)$ \\
\hline $\mathrm{Fe}_{2} \mathrm{O}_{3}$ & 7.4 & $(9.0)$ & 6.5 & $(6.6)$ & 6.8 & $(6.8)$ & 5.5 & $(5.6)$ \\
\hline $\mathrm{MgO}$ & 5.5 & $(6.7)$ & 8.1 & $(8 \cdot 3)$ & 6.6 & $(6.6)$ & 6.6 & $(5.7)$ \\
\hline $\mathrm{CaO}$ & 24.7 & $(3 n .2)$ & 34.1 & $(34.8)$ & 30.0 & $(30.0)$ & 31.0 & $(31.3)$ \\
\hline $\mathrm{MnO}$ & 0.0 & $(0.0)$ & 0.1 & $(0.1)$ & 0.1 & $(0.1)$ & 0.0 & $(0.0)$ \\
\hline Sro & 0.0 & $(0.0)$ & 0.6 & $(0.6)$ & 0.5 & $(0.5)$ & 0.5 & $(0.5)$ \\
\hline $\mathrm{BaO}$ & 0.0 & $(0.0)$ & 0.3 & $(0.3)$ & 0.3 & $(0.3)$ & 0.3 & $(0.3)$ \\
\hline $\mathrm{Na}_{2} \mathrm{O}$ & 1. .6 & $(2.0)$ & 0.8 & $(0.8)$ & 0.4 & $(0,4)$ & 0,7 & $(0.7)$ \\
\hline $\mathrm{K}_{2} \mathrm{O}$ & 0.3 & $(0.3)$ & 0.2 & $(0.2)$ & 0.2 & $(0.2)$ & 0.3 & $(0.3)$ \\
\hline $\mathrm{P}_{2} \mathrm{O}_{5}$ & 0.4 & $(0.4)$ & 0.0 & $(0.0)$ & 0.0 & $(0.0)$ & 0.0 & $(0.0)$ \\
\hline $\mathrm{SO}_{3}$ & 18.2 & $(--)$ & 2.0 & $(--)$ & 0.1 & $(--)$ & 1.1 & $(-)$ \\
\hline Total & 99.8 & & 91.9 & & 101.2 & & 73.2 & \\
\hline
\end{tabular}

\footnotetext{
* Source = Mineral Constitution Laboratories, The Pennsylvania State University, Pa.
} 
Table 19. Spectrochemical analysis of high temperature ash (AST:1) from Decker coal.

High temperature ash Upper portion of deposit mass

Weight percent of equivalent oxides ( $\mathrm{SO}_{3}$ free basis)

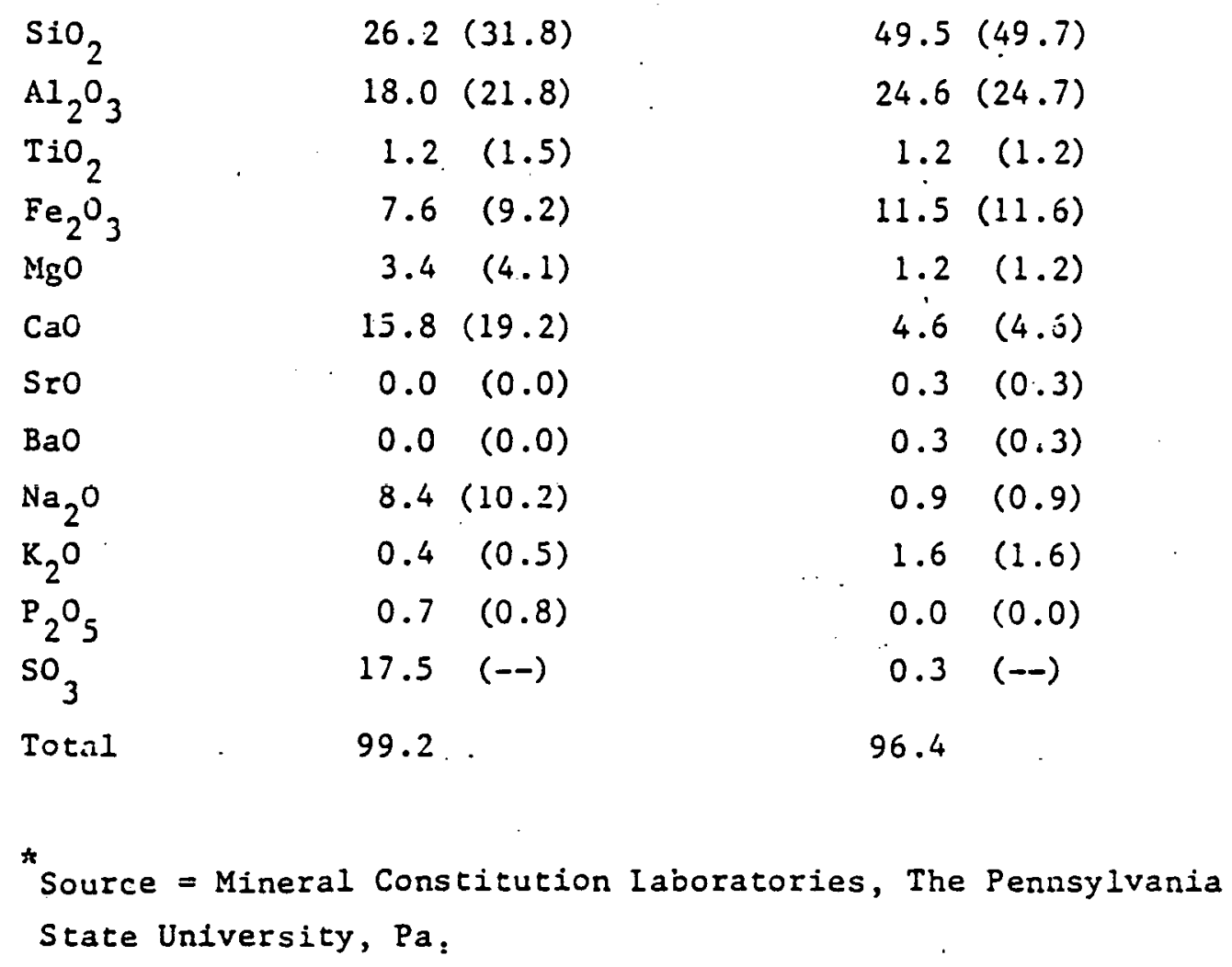


This trend was not observed for the low-rank coals in. Suite 1 , with the sole exception of Decker. Changes in $\mathrm{SiO}_{2}$ concentration were relatively small for the high-rank coals, with the exception again of the Upper Hiawatha $\# 1$. $\mathrm{SiO}_{2}$ concentration within the deposit was essentially constant irrespective of position within the deposit. On the other hand, the deposits from low-rank coals showed higher $\mathrm{SiO}_{2}$ concentrations than their respective ASTM ashes, except for the Powder River subbituminous coal. Trends in $\mathrm{SiO}_{2}$ concentration tracked those of CaO, suggesting that CaO may react with quartz or clays to form calcium silicates or aluminosilicates which make the ashes sticky and thus more prone to deposit. Changes in $\mathrm{Al}_{2} \mathrm{O}_{3}$ concentration were relatively small; the concentration appeared to remain essentially constant irrespective of position in the deposit, type of coals, or composition of the ASTM ash. This finding may indicate that most of the clays invariable participate in the ash deposit build-up for most of the tested coals. The ASTM ashes had, with the exception of the Texas lignite, higher Nago ooneentrations than the respective deposits, indicating that most of the sodium vaporizes in the coal flame under the conditions of the drop-tube furnace. Significant amounts of sodium and sulfur species were found concentrated in the dust around the edge of the substrate and along the cooled collecting probe near the furnace exit, suggesting that most of the sodium and sulfur follow the flue gas stream and condense in the cooler regions.

A synthetic coal with a starting mineral composition 
corresponding to Illinois \#6 was prepared with a mineral mixture of $29 \%$ pyrite, $5 \%$ calcite, $25 \%$ quartz, $5 \%$ kaolinite, and $35 \%$ illite. Figures 15 and 16 compare the SEM photomicrographs of the deposits from the synthetic coal and the actual Illinois \#6 coal. These figures show the similarity of deposit structure at different locations on the deposits. The EDS spectra showed the same types of compositions of the deposit spheres. It appears that calcite caused the fusion of most constituents in the synthetic coal. There were some irregular quartz particles that did not fuse into fly ash spheres. $x$-ray diffraction analysis confirmed these observations: at the top of the deposit there were phases containing silicon and aluminum (anorthite, $\mathrm{CaAl}_{2} \mathrm{Si}_{2} \mathrm{O}_{8}$, and augite, $\left.\mathrm{Ca}(\mathrm{Fe}, \mathrm{Mg}) \mathrm{Si}_{2} \mathrm{O}_{6}\right)$, showing that the melted top of the deposit did add calcite, clays and quartz in a manner similar to that of the actual coal.

A typical deposit formed from suite 2 coals is shown in Figure 17. Deposits could grow to heights of more than $20 \mathrm{~mm}$ in 15 - 30 min. The deposits characteristically have strongly adherent particles, a thin dust layer, a base, and a deposit mass with growth lines in the direction of the oncoming gas flow. The shape, color, and quantity of the deposit are coal-dependent. The consistency ranged from lightly sintered, highly porous deposits to strongly sintered, dense ones. Qualitative descriptions of the deposits formed in selected tests are given in Tables $20-22$.

The composition of deposits formed from Suite 2 coals was compared to the composition of the corresponding ashes prepared 


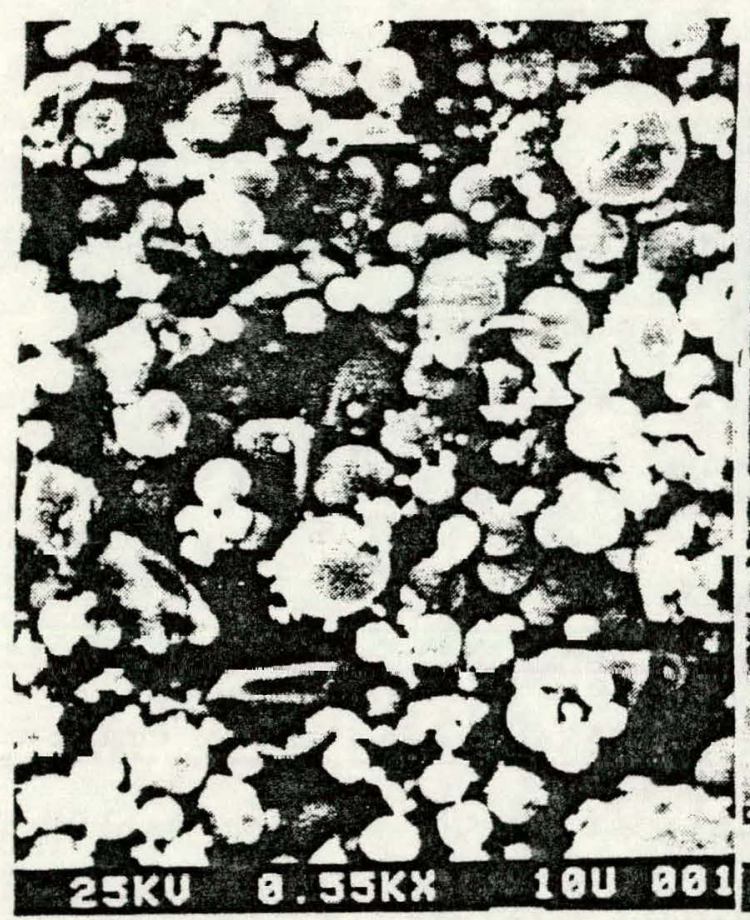

(a)

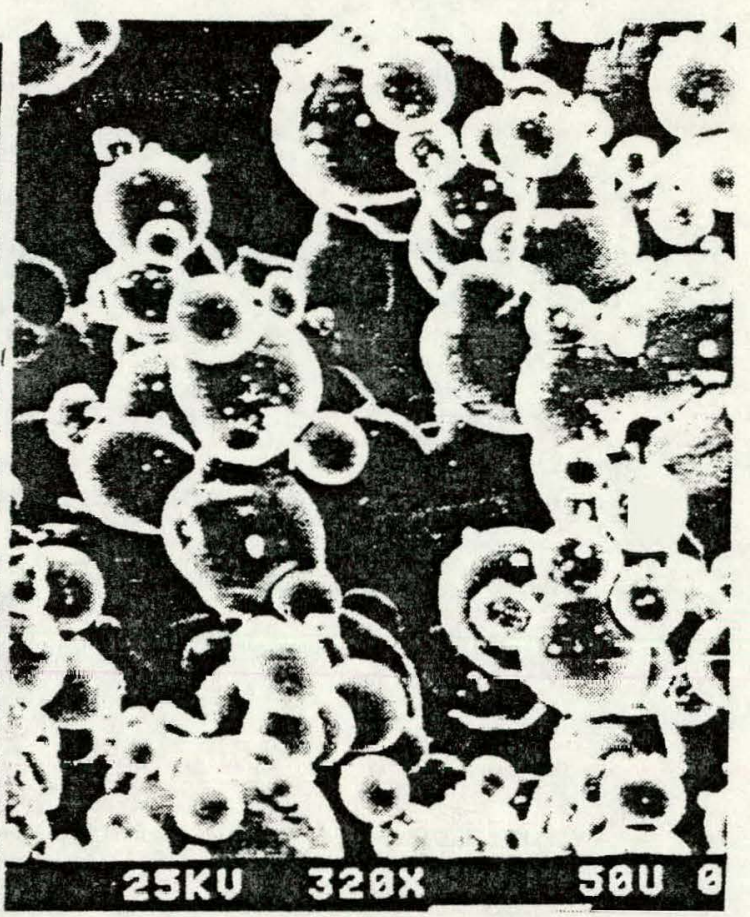

(b)

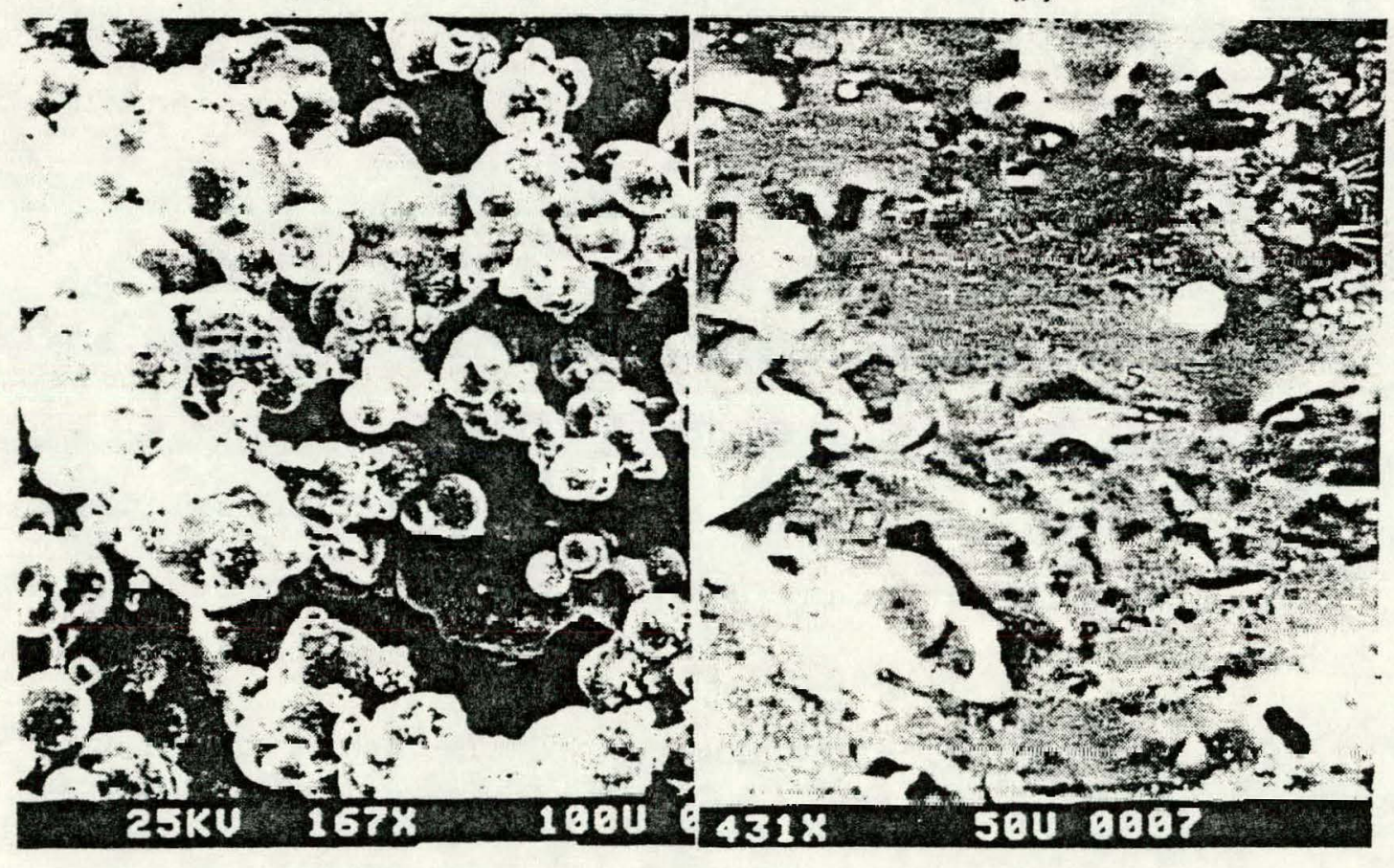

(c)

(d)

Figure 15. SEM photomicrographs of deposit from synthetic Illinois 非 6 coal; (a) dust material; (b) lower portion of deposit mass; (c) upper portion of deposit mass; (d) top portion of deposit mass. 


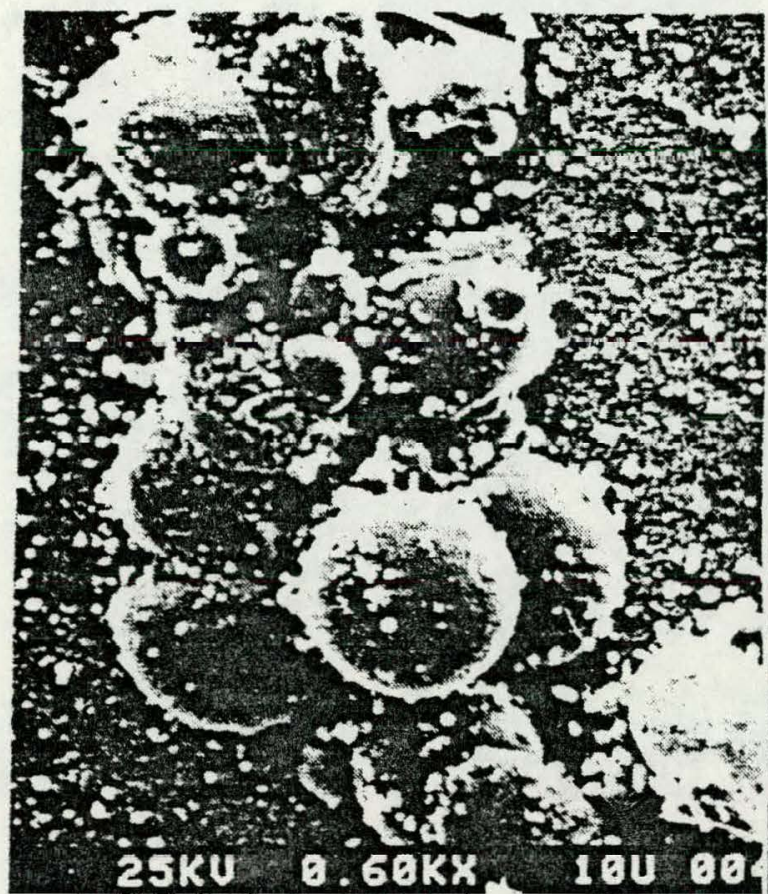

(a)

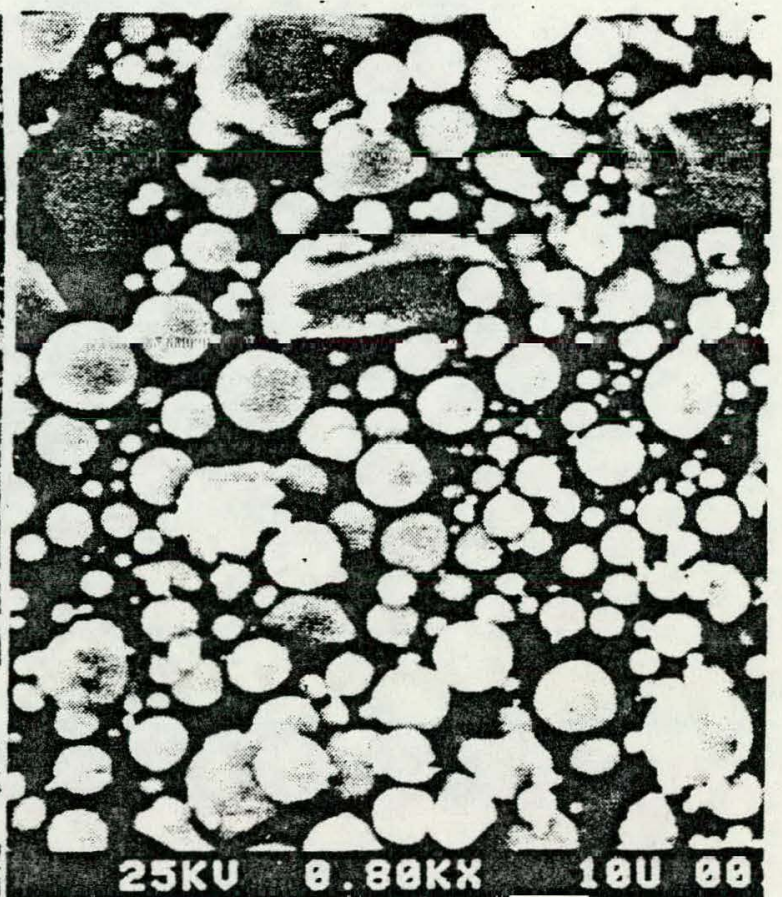

(b)

Figure 15 continued. SEM photomicrographs of (a) adherent material; and (b) collected fly ash from filter; both materials from Synthetic Illinois 非 coal. 


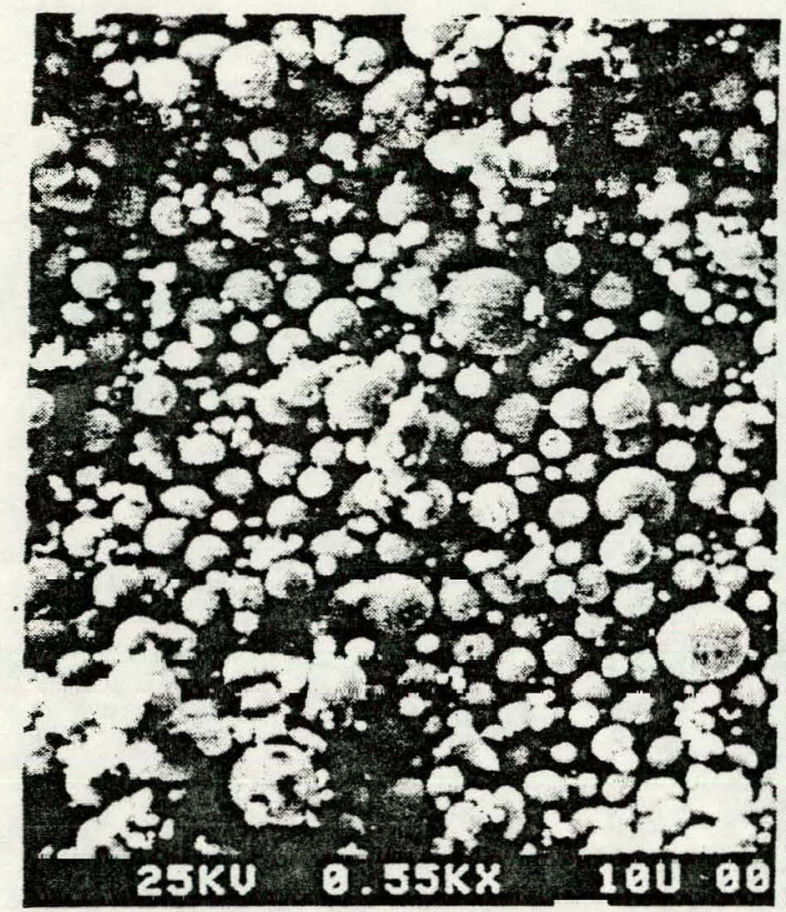

(a)

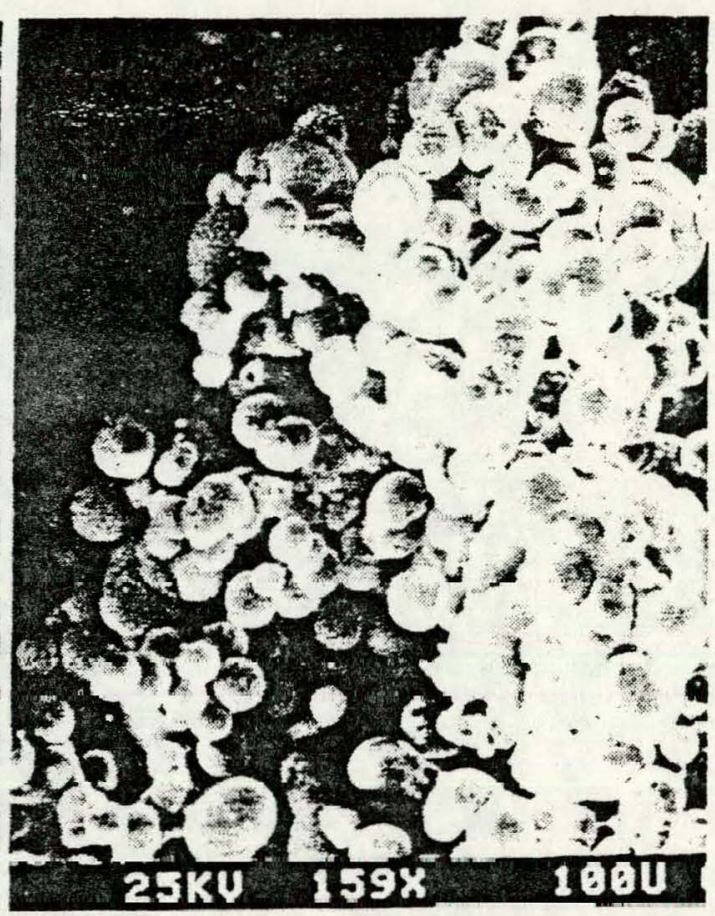

(b)

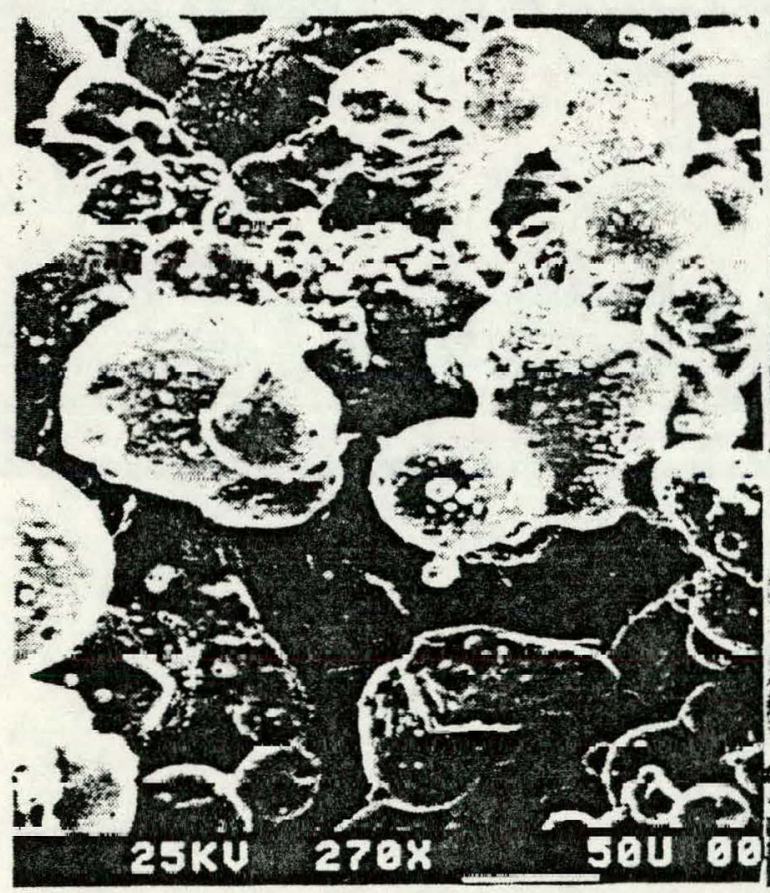

(c)

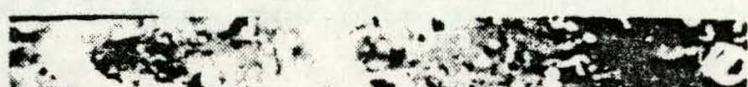

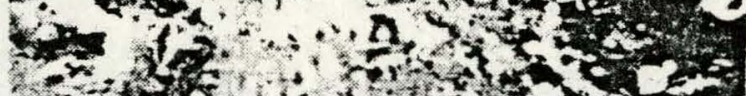

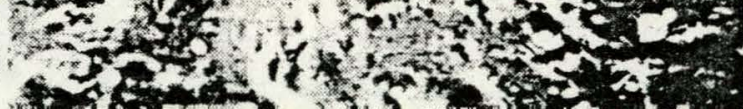

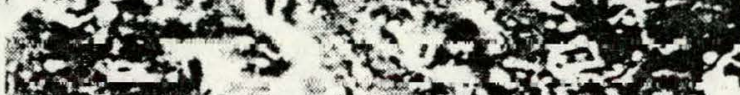

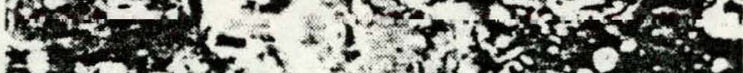

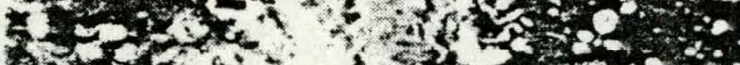

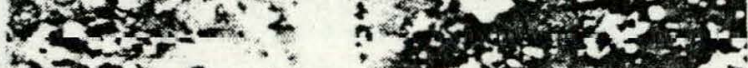

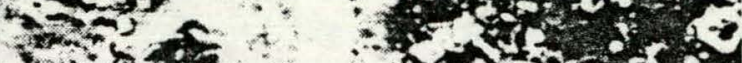

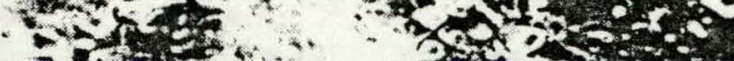
3n- $-\cdots$

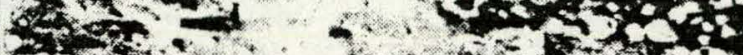

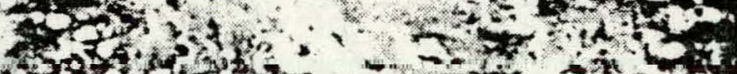

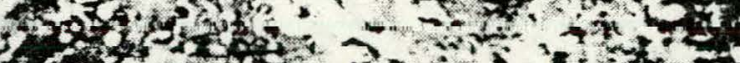

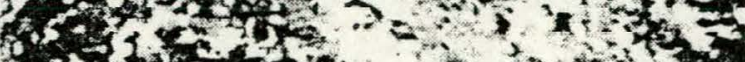

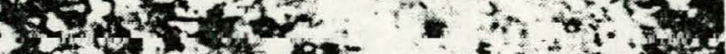

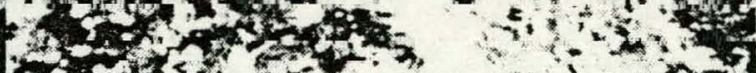
25KU

Figure 16. SEM photomicrographs of deposit from Illinois 非 coal; (a) dust material; (b) lower portion of deposit mass; (c) upper portion of deposit mass;

(d) top portion of deposit mass. 


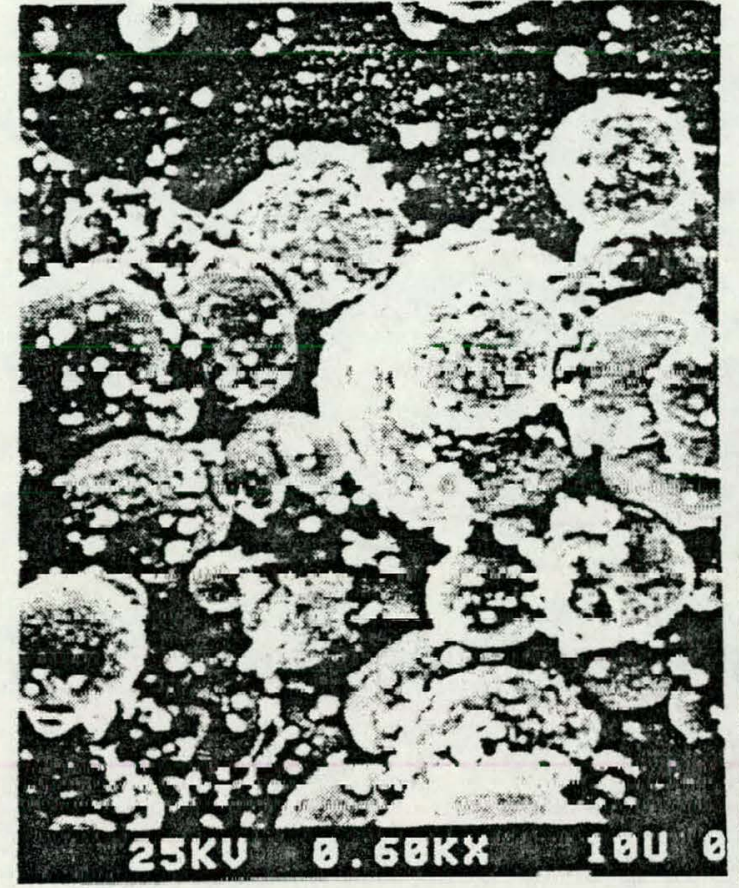

(a)

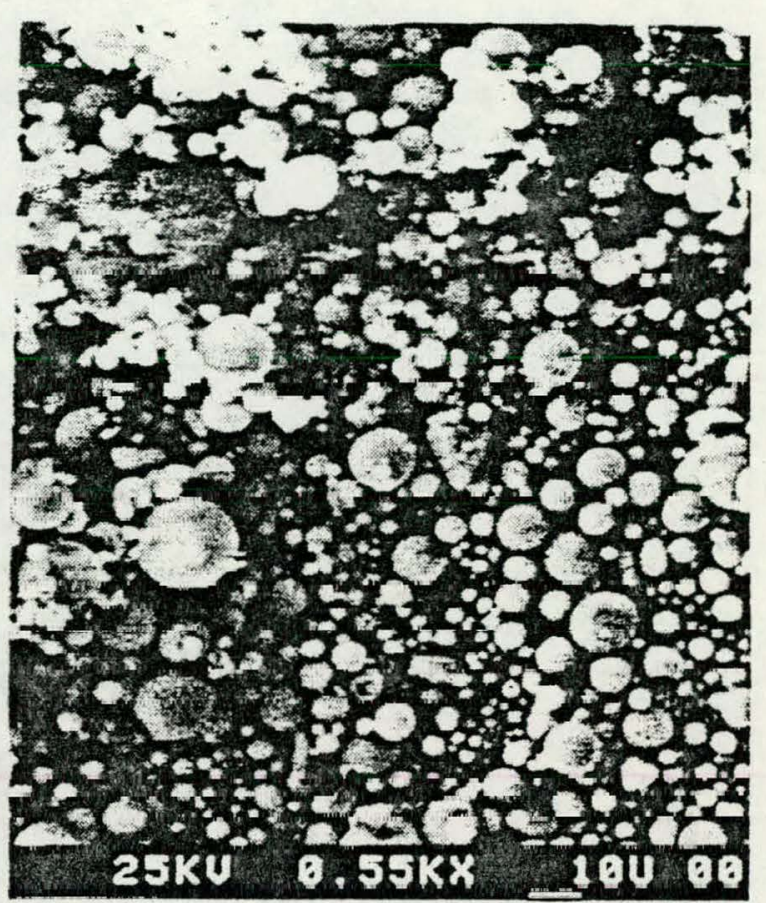

(b)

Figure 16 continued. SEM photomicrographs of (a) adherent material; and (b) collected fly ash from filter; both materials from Illinois 非 6 coal. 


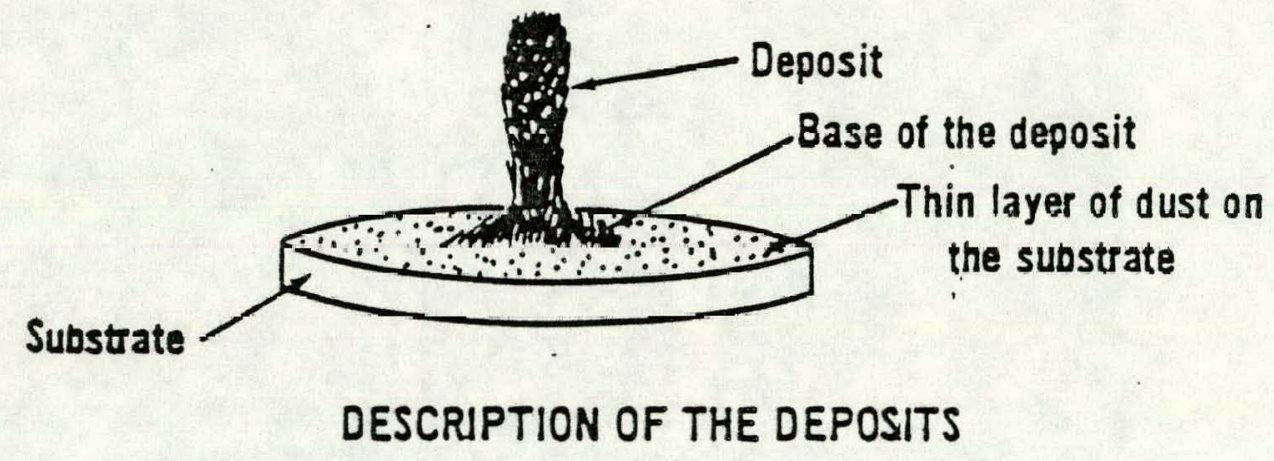

Figure 17. Typical deposit formed from a North Dakota lignite. 
Tab1e 20. Qualitative description of deposits from North Dakota lignites.

Coal

Deposit height, mm

Deposit top half

$\begin{array}{cl}\text { Deposit lower half } & (3.0 \mathrm{~mm}) \\ & \text { dark brown } \\ \text { no fusing } & \text { highly } \\ \text { sintered } & (5 \mathrm{~mm})\end{array}$

Base layer

Thin dust layer

Adherent material

$$
\text { Indian Head }
$$

16 small amount of fusing

brown to tan slightly sintered (Smn)

wilite to tan abundant (3mm)

very little dark brown
Beulah

15

dark brown no fusing $(7.5 \mathrm{~mm})$

dark brown no fusing slightly sintered (Gmm)

Velva

15

brown no fusing (10mm)

.

brown no lusing sintered (4mn)

brown to green brown slightly sintered (1. $5 \mathrm{mmn})$ silghtly sintered ( $1 \mathrm{~mm}$ )

white to tan

$\tan$

very litcle very little 
Table 20. Continues.

Coal.

Deposit height, $\mathrm{mm}$

Deposit top half

Deposit lower half

Base layer

Thin dust layer

Adherent material
Center $\left(1500^{\circ} \mathrm{C}\right)$

16

dark brown

completely fused

(7mm)

\section{dark brown \\ no fusing \\ (9mm!}

brown to $\tan$

very little

white

very little

abundant
Ion-exchanged

Center $\left(1500^{\circ} \mathrm{C}\right)$

$$
20
$$

19

browa

no fusing

$(8 \mathrm{~mm})$

brown

sintered

(5mm)

sintered

(bmm)

brown to tan

little

white

1Ettle

very little
Ion-exchanged

Center $\left(1400^{\circ} \mathrm{C}\right)$

\section{0}

light brown

no fusing

$(6 \mathrm{~mm})$

light brown

sintered

(9mm)

brown to tan

abundant

white

abundant

vêry little 
Table 20. Continued.

\begin{tabular}{|c|c|c|c|c|}
\hline Coa1 & $\begin{array}{l}\text { Gascoyne } \\
\text { Red } \\
\end{array}$ & $\begin{array}{l}\text { Gascoyne } \\
\text { White } \\
\end{array}$ & $\begin{array}{l}\text { Gascoyne } \\
\text { Blue }\end{array}$ & $\begin{array}{l}\text { Gascoyne } \\
\text { Yellow } \\
\end{array}$ \\
\hline Deposit height, mn & 16 & 17.5 & 15 & 15 \\
\hline Deposit top half & $\begin{array}{l}\text { glassy } \\
\text { highly fused } \\
\tan \\
(6 \mathrm{~mm})\end{array}$ & $\begin{array}{l}\text { glassy } \\
\text { fused } \\
\text { highly porous } \\
\text { tan } \\
(5 \mathrm{~mm})\end{array}$ & $\begin{array}{l}\text { slightly } \\
\text { glassy } \\
\text { fused } \\
\text { dark brown } \\
\text { (10mm) }\end{array}$ & $\begin{array}{l}\text { glassy } \\
\text { highly porous } \\
\text { tan } \\
(10 \mathrm{~mm})\end{array}$ \\
\hline Deposit lower half & $\begin{array}{l}\text { sintered } \\
\text { no fusing } \\
(9 \mathrm{~mm})\end{array}$ & $\begin{array}{l}\text { sincered } \\
\text { no fusing } \\
(10.5 \mathrm{~mm})\end{array}$ & $\begin{array}{l}\text { sintered } \\
\text { no fusing } \\
\text { (6rim) }\end{array}$ & $\begin{array}{l}\text { sintered } \\
\text { no fusing } \\
(4 \mathrm{~mm})\end{array}$ \\
\hline Base layer & $\begin{array}{l}\text { slightly } \\
\text { sintered } \\
\text { tan to white }\end{array}$ & $\begin{array}{l}\text { slightly } \\
\text { sintered } \\
\tan \end{array}$ & $\begin{array}{l}\text { slight } 1 y \\
\text { sintered } \\
\tan \end{array}$ & $\begin{array}{l}\text { slightly } \\
\text { sintered } \\
\text { tan to white }\end{array}$ \\
\hline Thin dust layer & white & white & white & white \\
\hline Adherent material & little & little & little & little \\
\hline
\end{tabular}


Table 21. Qualitative description cf subbituminous deposits.

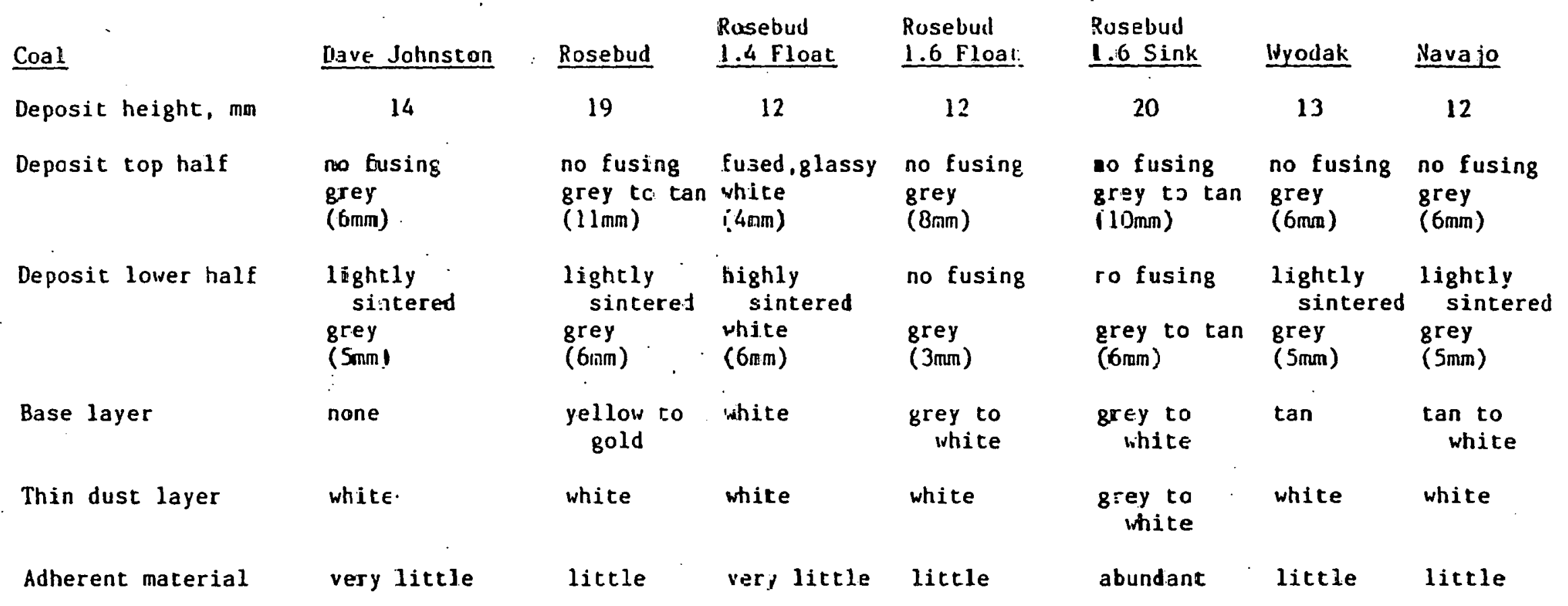


Table 22. Qualitative description of Texas lignite deposits.

\begin{tabular}{|c|c|c|c|c|c|}
\hline Coal & $\begin{array}{l}\text { San Miguel } \\
\left(1500^{\circ} \mathrm{C}\right)\end{array}$ & $\begin{array}{l}\text { Ion-exchanged } \\
\text { San Higue } 1 \\
\left(1500^{\circ} \mathrm{C}\right)\end{array}$ & $\begin{array}{l}\text { San Migue1 } \\
\left(1400^{\circ} \mathrm{C}\right)\end{array}$ & $\begin{array}{l}\text { Ion-exchanged } \\
\text { San Miguel } \\
\left(1400^{\circ} \mathrm{C}\right)\end{array}$ & $\begin{array}{l}\text { Martin } \\
\text { Lake }\end{array}$ \\
\hline Deposit height, mm & 14 & 18 & 13 & 17. & 13 \\
\hline Deposit top half & $\begin{array}{l}\text { grey } \\
\text { fused } \\
\text { porous } \\
(5 \mathrm{~mm})\end{array}$ & $\begin{array}{l}\text { grey-tan } \\
\text { sintered. } \\
(8 \mathrm{~mm})\end{array}$ & $\begin{array}{l}\text { grey-tan } \\
\text { very lightly } \\
\text { sintered } \\
(6 \mathrm{mn})\end{array}$ & $\begin{array}{l}\tan \\
\text { very soft } \\
\text { deposit } \\
(7 \mathrm{~mm})\end{array}$ & $\begin{array}{l}\text { brown } \\
\text { highly } \\
\text { sintered } \\
(6 \mathrm{~mm})\end{array}$ \\
\hline Depasit lower half & $\begin{array}{l}\text { grey-tan } \\
\text { sintered } \\
(6 \mathrm{~mm})\end{array}$ & $\begin{array}{l}\text { grey } \\
\text { lightly } \\
\quad \text { sintered } \\
(8 \mathrm{~mm})\end{array}$ & $\begin{array}{l}\text { grey-tan } \\
\text { sintered } \\
(5 \mathrm{~mm})\end{array}$ & $\begin{array}{l}\text { grey-tan } \\
\text { lightly } \\
\text { sintered } \\
(7 \mathrm{~mm})\end{array}$ & $\begin{array}{l}\text { brown-tan } \\
\text { sintered } \\
(4 \mathrm{~mm})\end{array}$ \\
\hline Base & $\begin{array}{l}\text { grey } \\
\text { lightly } \\
\quad \text { sintered }\end{array}$ & $\begin{array}{l}\text { grey } \\
\text { very lightly } \\
\text { sintered }\end{array}$ & $\begin{array}{l}\text { grey } \\
\text { lightly } \\
\quad \text { sintered }\end{array}$ & $\begin{array}{l}\text { grey } \\
\text { very lightly } \\
\quad \text { sintered }\end{array}$ & $\begin{array}{l}\tan \\
\text { lightly } \\
\quad \text { sintered }\end{array}$ \\
\hline Thin dust layer & $\begin{array}{l}\text { white } \\
\text { very little }\end{array}$ & $\begin{array}{l}\text { grey-white } \\
\text { very little }\end{array}$ & $\begin{array}{l}\text { grey-white } \\
\text { little }\end{array}$ & $\begin{array}{l}\text { white } \\
\text { very little }\end{array}$ & $\begin{array}{l}\tan \\
\text { little }\end{array}$ \\
\hline Adherent material & abundant & little & little & litele & little \\
\hline
\end{tabular}


under standard ASTM conditions. The results of this comparison are given in Tables 23 - 26. The most striking difference is the lower concentration of sodium and sulfur in the deposit. This difference may be due to these species remaining in the gas phase at the high gas temperatures $\left(1264^{\circ} \mathrm{C}\right)$ passing through the constrictor or that the sodium and sulfur concentrate in the smaller size fractions and are more likely to follow gas streamlines without being deposited. The concentration of silicon appears higher in most deposits than in the ash. This may be due to large particles of silica impacting the substrate or the deposit. The concentrations of iron and calcium are lower in the deposit than in the ash in most cases. The lower calcium concentration may be due to the fact that most of the calcium is organically bound and thus more likely to occur in the smaller particle sizes, behaving similarly to sodium and sulfur. Iron is an anomaly; the concentration of iron would be expected to be higher in the deposit than in the ash because the high density of Irun yullicles increases the possibility of impooting the deposit and substrate.

The variation in composition across a deposit formed from Indian Head lignite was determined by SEM-EDS analysis. Sodium deoreases from the base of the deposit. th the top and in most cases decreases from the centerline to the outer edge. These trends are thought due to the relative volatility of sodiumcontaining species and that particles containing higher concentrations of sodium stick more readily and thus are 
Table 23. Composition of bulk iorth Daliota lignite deposits compared to ASTil ash (weight percent as equivalent oxide $\mathrm{SO}_{3}$ free basis).

\begin{tabular}{|c|c|c|c|c|c|c|c|c|c|c|}
\hline \multirow[b]{2}{*}{ Oxide } & \multicolumn{2}{|c|}{ Indian Head } & \multicolumn{2}{|c|}{ Beulah } & \multicolumn{2}{|c|}{ Velva } & \multicolumn{2}{|c|}{ Center } & \multicolumn{2}{|c|}{ I/E $E^{+}$Center } \\
\hline & $\begin{array}{l}\text { ASTM } \\
\text { Ash }\end{array}$ & $\begin{array}{l}\text { Bulk } \\
\text { Deposit }\end{array}$ & $\begin{array}{l}\text { ASTi } \\
\text { Ash }\end{array}$ & $\begin{array}{l}\text { Bulk } \\
\text { Deposit }\end{array}$ & $\begin{array}{l}\text { ASTM } \\
\text { Ash }\end{array}$ & $\begin{array}{l}\text { Bulk } \\
\text { Deposit }\end{array}$ & $\begin{array}{l}\text { ASTI } \\
\text { Ash }\end{array}$ & $\begin{array}{l}\text { Bulk } \\
\text { Deposit }\end{array}$ & $\begin{array}{l}\text { ASTM } \\
\text { Ash }\end{array}$ & $\begin{array}{l}\text { Bulk } \\
\text { Deposit }\end{array}$ \\
\hline $\mathrm{SiO}_{2}$ & 25.6 & 23.2 & 16.5 & 34.8 & 26.0 & $38 . B$ & 27.1 & 31.1 & 35.1 & 40.6 \\
\hline $\mathrm{A}_{2} \mathrm{O}_{3}$ & 14.5 & 16.6 & 12.7 & 14.7 & 13.4 & 14.0 & 14.9 & 17.3 & 19.6 & 22.0 \\
\hline $\mathrm{Fe}_{2} \mathrm{O}_{3}$ & 10.3 & 9.3 & 12.8 & 10.8 & 8.3 & 5.9 & 14.2 & 11.7 & 18.7 & 13.0 \\
\hline $\mathrm{TiO}_{2}$ & 1.2 & 1.1 & 1.4 & 0.4 & 1.1 & 0.3 & 0.5 & 0.5 & 0.7 & 0.7 \\
\hline $\mathrm{P}_{2} \mathrm{O}_{5}$ & 0.6 & 0.3 & 1.8 & 0.3 & 0.6 & 0.0 & 0.1 & 0.1 & 0.2 & 0.0 \\
\hline $\mathrm{CaO}$ & 25.4 & 35.7 & 12.0 & 30.3 & 37.3 & 30.3 & 26.0 & 23.8 & 18.3 & 18.9 \\
\hline $\mathrm{MgO}$ & 7.9. & 6.9 & 8.6 & 3.4 & 10.6 & 9.2 & 9.5 & 13.7 & 3.2 & 3.6 \\
\hline $\mathrm{Va}_{2} \mathrm{O}$ & 14.5 & 6.9 & 19.4 & 5.0 & 2.8 & 1.4 & 3.6 & 2.4 & 0.3 & 0.7 \\
\hline $\mathrm{K}_{2} \mathrm{O}$ & 0.1 & 0.0 & 0.0 & 0.2 & 0.1 & 0.1 & 0.8 & 0.4 & 0.6 & 0.5 \\
\hline $\mathrm{SO}_{3}^{*}$ & 15.9 & 5.2 & 30.0 & 4.6 & 16.7 & 3.3 & 20.4 & 2.9 & 10.6 & 1.5 \\
\hline
\end{tabular}

: $-\mathrm{SO}_{3}$ included for comparison purposes.

$+-I / E=$ Ion exchanged. 
Table 24. Composition oミ bulk Gascoyne lignite deposits compared to ASTM asi (weight percent as equivalent oxide $\mathrm{SO}_{3} \doteqdot$ iree basis).

\begin{tabular}{|c|c|c|c|c|c|c|c|c|}
\hline \multirow[b]{2}{*}{ Oxide } & \multicolumn{2}{|c|}{ Red } & \multicolumn{2}{|c|}{ White } & \multicolumn{2}{|c|}{ Blue } & \multicolumn{2}{|c|}{ Yellow } \\
\hline & $\begin{array}{l}\text { ASTN } \\
\text { Ash }\end{array}$ & $\begin{array}{l}\text { Bulk } \\
\text { Defosit }\end{array}$ & $\begin{array}{l}\text { ASTM } \\
\text { Ash } \\
\end{array}$ & $\begin{array}{l}\text { Bulk } \\
\text { Deposit }\end{array}$ & $\begin{array}{l}\text { ASTM } \\
\text { Ash } \\
\end{array}$ & $\begin{array}{l}\text { Bulk } \\
\text { Deposit }\end{array}$ & $\begin{array}{l}\text { ASTi } \\
\text { Ash }\end{array}$ & $\begin{array}{l}3 u 1 k \\
\text { Jeposit }\end{array}$ \\
\hline $\mathrm{SiO}_{2}$ & 51.9 & 68.2 & 56.8 & 67.6 & 28.8 & 45.3 & 38.0 & 48.0 \\
\hline $\mathrm{Al}_{2} \mathrm{O}_{3}$ & 13.3 & 9.8 & 13.7 & 8.7 & 12.4 & 11.3 & 18.0 & 17.8 \\
\hline $\mathrm{Fe}_{2} \mathrm{O}_{3}$ & 5.5 & 3.1 & 3.4 & 4.7 & 6.4 & 4.3 & 2.8 & 2.3 \\
\hline $\mathrm{TiO}_{2}$ & 1.7 & 1.3 & 1.6 & 0.9 & 0.9 & 0.5 & 1.9 & 1.4 \\
\hline $\mathrm{P}_{2} \mathrm{O}_{5}$ & 1.0 & 0.0 & 0.9 & 0.0 & 0.9 & 0.0 & 1.7 & 0.2 \\
\hline $\mathrm{CaO}$ & 15.0 & 11.2 & 14.1 & 12.1 & 31.0 & 29.7 & 26.5 & 21.5 \\
\hline $\mathrm{MgO}$ & 8.9 & 2.1 & 4.7 & 1.9 & 10.5 & 5.5 & 9.3 & 9.0 \\
\hline $\mathrm{Na}_{2} \mathrm{O}$ & 2.3 & 1.4 & 4.0 & 3.6 & 8.8 & 3.6 & 1.9 & 0.7 \\
\hline $\mathrm{K}_{2} \mathrm{O}$ & 0.5 & 0.3 & 0.9 & 0.4 & 0.1 & 0.3 & 0.0 & 0.1 \\
\hline $\mathrm{SO}_{3}$ & 16.6 & 2.9 & 12.2 & 2.8 & 21.4 & 2.8 & 22.5 & 2.8 \\
\hline
\end{tabular}


Table 29. Composition of bulk subbituminous coal deposits compared to ASTM ash (weight percent as equivalent oxide $\mathrm{SO}_{3}$ free basis).

\begin{tabular}{|c|c|c|c|c|c|c|c|c|c|c|}
\hline \multirow{2}{*}{ Oxide } & \multicolumn{2}{|c|}{ Dave Johnston } & \multicolumn{2}{|c|}{ Rosejud } & \multicolumn{2}{|c|}{ Rosebud 1.4 Float } & \multicolumn{2}{|c|}{ Wyodak } & \multicolumn{2}{|c|}{ Nava jo } \\
\hline & $\begin{array}{l}\text { ASTM } \\
\text { Ash } \\
\end{array}$ & $\begin{array}{l}\text { Bulk } \\
\text { Deposit }\end{array}$ & $\begin{array}{l}\text { ASTM } \\
\text { Ash }\end{array}$ & $\begin{array}{l}\text { Bulk } \\
\text { Deposit }\end{array}$ & $\begin{array}{l}\text { ASTM } \\
\text { Ash }\end{array}$ & $\begin{array}{l}\text { Bulk } \\
\text { Deposit }\end{array}$ & $\begin{array}{l}\text { ASTM } \\
\text { Ash }\end{array}$ & $\begin{array}{l}\text { Bulk } \\
\text { Deposit }\end{array}$ & $\begin{array}{l}\text { ASTh } \\
\text { Ash }\end{array}$ & $\begin{array}{l}\text { Bulk } \\
\text { Deposit }\end{array}$ \\
\hline $\mathrm{SiO}_{2}$ & 37.0 & 58.7 & 44.7 & 55.9 & 36.8 & 46.7 & 30.6 & 47.7 & 56.9 & 64.5 \\
\hline $\mathrm{Al}_{2} \mathrm{O}_{3}$ & 14.6 & 15.4 & 22.7 & 24.0 & 24.8 & 26.7 & 19.1 & 17.1 & 27.5 & 23.2 \\
\hline $\mathrm{Fe}_{2} \mathrm{O}_{3}$ & 8.4 & 5.8 & 6.9 & 5.0 & 1.5 & 0.9 & 8.5 & 4.8 & 5.5 & 4.1 \\
\hline $\mathrm{TiO}_{2}$ & 0.8 & 0.7 & 1.5 & 0.8 & 1.4 & 1.0 & 1.5 & 0.9 & 1.3 & 1.0 \\
\hline $\mathrm{P}_{2} \mathrm{O}_{5}$ & 0.8 & 0.0 & 0.8 & 0.5 & 1.2 & 0.1 & 1.9 & 0.3 & 0.2 & 0.2 \\
\hline $\mathrm{CaO}$ & 33.0 & 16.7 & 15.9 & 12.1 & 22.6 & 16.2 & 29.4 & 26.1 & 4.4 & 4.0 \\
\hline $\mathrm{MgO}$ & 5.0 & 1.2 & 6.6 & 2.2 & 10.9 & 8.6 & 7.6 & 2.3 & 2.0 & 2.1 \\
\hline $\mathrm{Na}_{2} \mathrm{O}$ & 0.0 & 0.3 & 0.6 & 0.3 & 0.9 & 0.2 & 0.9 & 0.4 & 1.4 & 1.0 \\
\hline$K_{2} 0$ & 0.5 & 1.2 & 0.4 & 0.2 & 0.0 & 0.2 & 0.4 & 0.4 & 0.0 & 0.0 \\
\hline $\mathrm{SO}_{3}$ & 21.3 & 2.7 & 14.6 & 2.6 & 13.2 & 2.8 & 22.4 & 3.5 & 4.1 & 1.5 \\
\hline
\end{tabular}


Table 26. Composition of bulk Texas lignite deposits compared to ASTM ash (weight fercent as equivalent oxide $\mathrm{SO}_{3}$ free basis).

\begin{tabular}{|c|c|c|c|c|c|c|}
\hline \multirow[b]{3}{*}{ Oxide } & \multicolumn{2}{|c|}{ San Migue1 } & \multicolumn{2}{|c|}{ I/E San Miguel } & \multicolumn{2}{|c|}{ Martin Lake } \\
\hline & ASTM & Fulk & $\overline{\text { ASTI1 }}$ & Bulk & $\overline{A S T M}$ & Bulk \\
\hline & Ash & Deposit & Ash & Deposit & Ash & Deposit \\
\hline $\mathrm{SHO}_{2}$ & 59.3 & 6.4 .5 & 72.3 & 77.4 & 26.1 & 39.0 \\
\hline $\mathrm{Al}_{2} \mathrm{O}_{3}$ & 16.4 & 15.4 & 17.6 & 16.2 & 15.6 & 15.4 \\
\hline $\mathrm{Fe}_{2} \mathrm{O}_{3}$ & 5.3 & 4.2 & 5.6 & 4.0 & 21.0 & 12.2 \\
\hline $\mathrm{TiO}_{2}$ & 0.9 & 0.8 & 0.8 & 0.9 & 1.1 & 0.0 \\
\hline $\mathrm{P}_{2} \mathrm{O}_{5}$ & 0.4 & 0.2 & 0.1 & 0.2 & 0.9 & 0.4 \\
\hline $\mathrm{CaO}$ & 8.8 & 7.6 & 2.7 & 1.0 & 21.1 & 16.7 \\
\hline $\mathrm{MgO}$ & 0.9 & 0.8 & 0.3 & 0.2 & 9.7 & 2.9 \\
\hline $\mathrm{Na}_{2} \mathrm{O}$ & 5.3 & 4.2 & 0.1 & 0.0 & 4.2 & 0.8 \\
\hline $\mathrm{K}_{2} \mathrm{O}$ & 2.7 & 2.3 & 0.5 & 0.1 & 0.4 & 0.4 \\
\hline $\mathrm{SO}_{3}$ & 10.9 & 2.1 & 2.4 & 1.1 & 23.5 & 3.1 \\
\hline
\end{tabular}


concentrated along the centerline of the deposit. The trends for silicon concentrations are similar to those of sodium. This similarity may be due to the interaction of sodium with silicates, causing the silicates to be sticky and thus more likely to deposit along the centerline. Changes in aluminum concentration are relatively small; the concentration is essentially constant irrespective of position in the deposit. The calcium concentration changes inversely to the sodium concentration. The highest calcium concentration is at the top of the deposit; in addition, high calcium contents are also noted at the lower outer edges of the deposit. The high concentration of calcium at the top of the deposit is probably due to the presence of a molten phase which traps most of the particles which pass through the constrictor. Iron concentrations are generally higher along the centerline of the deposit.

Tables 27 - 31 summarize the crystalline phases identified in the deposits from some of the suite 2 coals. The relative abundance of the alkali and alkaline earth aluminosilicates decreases from the top of the deposit to the base. The higher temperature $(1200 \circ \mathrm{C})$ at the top of the deposit promotes the formation of these phases due to increased interaction of the ash constituents during melting. Oxides such as periclase, lime, hematite, spinel, and quartz are commonly found at the base of the deposit. There is also abundant glass material present in the lower sections of the deposits. The crystalline species identified at the base of the deposit are very similar to that of 
Table 27. Crystalline phases identified in North Dakota Iignite deposits using $x$-ray diffraction.

(phases listed in order of decreasing abundance)

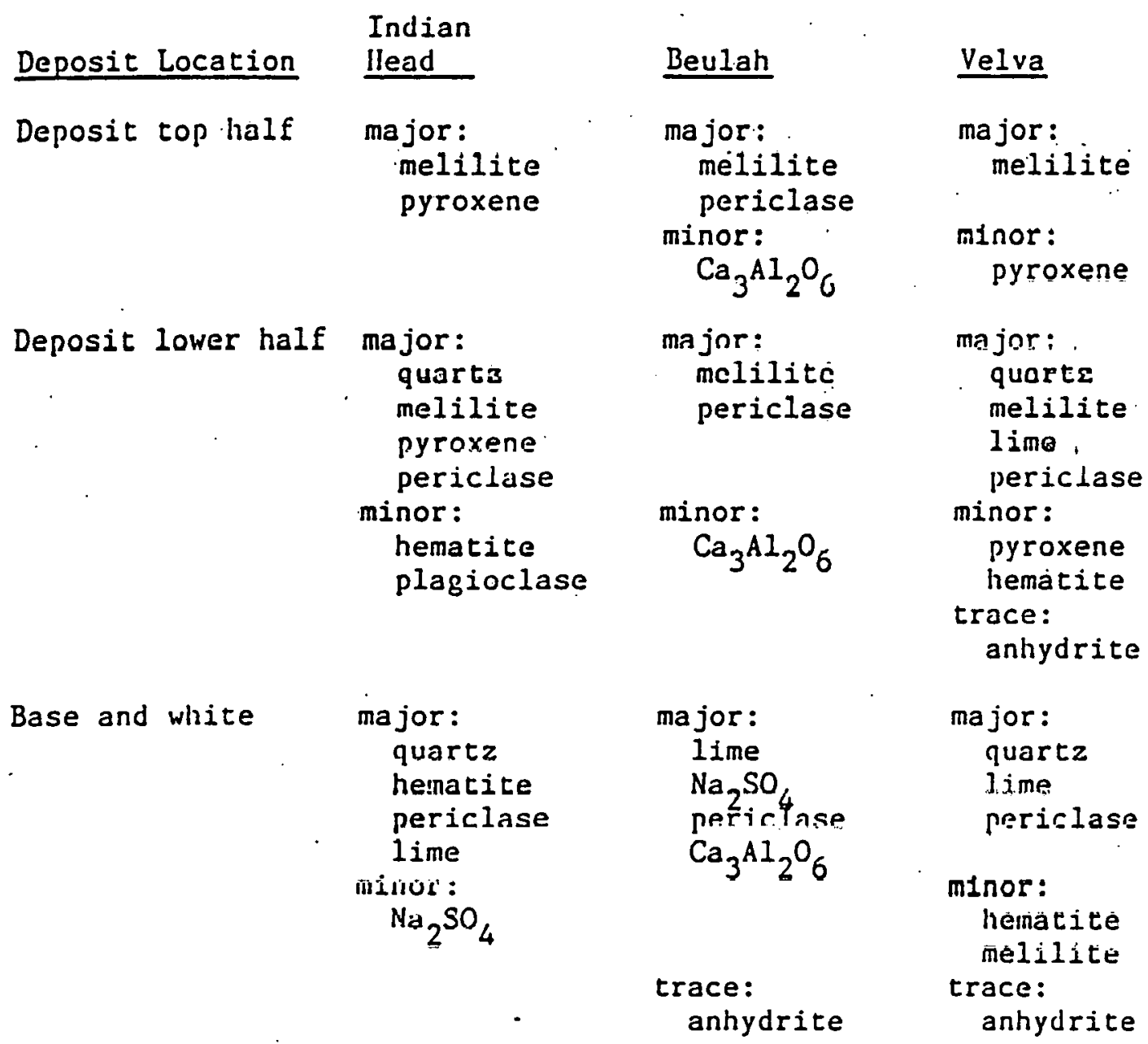


Table 27. Continued.

\begin{tabular}{|c|c|c|c|c|}
\hline Deposit Location & Center $\left(1500^{\circ} \mathrm{C}\right)^{*}$ & $\mathrm{I} / \mathrm{E}^{+}$Center $\left(1500^{\circ} \mathrm{C}\right)$ & Center $\left(1400^{\circ} \mathrm{C}\right)$ & I/E Center $\left(1400^{\circ} \mathrm{C}\right)$ \\
\hline Deposit top half & $\begin{array}{l}\text { ma.jor: } \\
\text { pyroxene } \\
\text { minor: } \\
\text { quartz }\end{array}$ & $\begin{array}{l}\text { major: } \\
\text { pyroxene } \\
\text { plagioclase } \\
\text { minor: } \\
\text { quartz } \\
\text { melilite }\end{array}$ & $\begin{array}{l}\text { major: } \\
\text { melilite } \\
\text { pyroxene } \\
\text { minor: } \\
\text { quartz } \\
\text { lime } \\
\text { spinel } \\
\text { periclase }\end{array}$ & $\begin{array}{l}\text { ma jor: } \\
\text { amorphous } \\
\text { quartz } \\
\text { minor: } \\
\text { plagioclase } \\
\text { melilite } \\
\text { pyroxene } \\
\text { hematite }\end{array}$ \\
\hline Deposit lower half & $\begin{array}{l}\text { major: } \\
\text { pyroxene } \\
\text { minor: } \\
\text { quartz } \\
\text { spinel } \\
\text { periclase }\end{array}$ & $\begin{array}{l}\text { major: } \\
\quad \text { quartz } \\
\text { minor: } \\
\text { pyroxene } \\
\text { plagioclase } \\
\text { melilite } \\
\text { hematite } \\
\text { spinel } \\
\text { periclase }\end{array}$ & $\begin{array}{l}\text { major: } \\
\text { melilite } \\
\text { pyroxene } \\
\text { minor: } \\
\text { quartz } \\
\text { lime } \\
\text { spinel } \\
\text { periclase }\end{array}$ & $\begin{array}{l}\text { major: } \\
\text { amorphous } \\
\text { minor: } \\
\text { quartz } \\
\text { plagioclase } \\
\text { trace: } \\
\text { pyroxene }\end{array}$ \\
\hline Base and white & $\begin{array}{l}\text { major: } \\
\quad \text { amorphous }\end{array}$ & $\begin{array}{l}\text { ma jor: } \\
\text { quartz } \\
\text { amorplious }\end{array}$ & $\begin{array}{l}\text { ma jor: } \\
\text { quartz } \\
\text { melilite } \\
\text { lime }\end{array}$ & $\begin{array}{l}\text { major: } \\
\text { amorphous }\end{array}$ \\
\hline & $\begin{array}{l}\text { minor: } \\
\text { periclase } \\
\text { hematite } \\
\text { spinel } \\
\text { anhydrite }\end{array}$ & $\begin{array}{l}\text { minor: } \\
\text { spinel }\end{array}$ & $\begin{array}{l}\text { minor: } \\
\text { spinel } \\
\text { pyroxerie } \\
\text { trace: } \\
\text { anhydrite }\end{array}$ & $\begin{array}{l}\text { minor: } \\
\text { quartz } \\
\text { trace: } \\
\text { hematite } \\
\text { spinel }\end{array}$ \\
\hline
\end{tabular}


Table 28. Crystalline phases identified in Gasco!ne lignite deposits using x-ray diffraction. (phases listed in order of decreasing abundance)

\begin{tabular}{|c|c|c|c|c|}
\hline Deposit Location & Gascovine Red & Gascovne thite & Gascoyne Blie & Gascavne Yellon: \\
\hline Deposit top half & $\begin{array}{l}\text { ma jor: } \\
\text { quartz } \\
\text { pyroxene } \\
\text { amorphous }\end{array}$ & $\begin{array}{l}\text { ma jor: } \\
\text { ąuartz } \\
\text { amorphous }\end{array}$ & $\begin{array}{l}\text { major: } \\
\text { nelilite } \\
\text { minor: } \\
\text { pyroxene } \\
\text { trace: } \\
\text { quartz }\end{array}$ & $\begin{array}{l}\text { major: } \\
\text { quartz } \\
\text { pyroxene }\end{array}$ \\
\hline \multirow[t]{3}{*}{ Deposit lower ha1f } & $\begin{array}{l}\text { ma jor: } \\
\text { quartz }\end{array}$ & $\begin{array}{l}\text { ma jot: } \\
\text { quart. } \\
\text { melilite } \\
\text { pyroxene }\end{array}$ & $\begin{array}{l}\text { major } \\
\text { meli11te } \\
\text { quartz }\end{array}$ & $\begin{array}{l}\text { major: } \\
\text { quartz } \\
\text { melllite }\end{array}$ \\
\hline & $\begin{array}{l}\text { miror: } \\
\text { melilite } \\
\text { pyroxene }\end{array}$ & $\begin{array}{l}\text { minor: } \\
\text { spinel }\end{array}$ & $\begin{array}{l}\text { minor: } \\
\text { periclase } \\
\text { henatite } \\
\text { pyroxene }\end{array}$ & $\begin{array}{l}\text { nino: : } \\
\text { periclase } \\
\text { pyroxene }\end{array}$ \\
\hline & $\begin{array}{l}\text { trace: } \\
\text { periclase } \\
\text { amorphous }\end{array}$ & & & $\begin{array}{l}\text { trace: } \\
\text { hematite } \\
\text { plagioclase }\end{array}$ \\
\hline \multirow[t]{2}{*}{ Base and white } & $\begin{array}{l}\text { ma jor: } \\
\quad \text { quartz }\end{array}$ & $\begin{array}{l}\text { majar: } \\
\text { quartz }\end{array}$ & $\begin{array}{l}\text { ma jor: } \\
\text { periclase } \\
\text { henatite } \\
\text { lime }\end{array}$ & $\begin{array}{l}\text { major: } \\
\text { quartz } \\
\text { periclase }\end{array}$ \\
\hline & $\begin{array}{l}\text { minor: } \\
\text { periclase } \\
\text { nelilite } \\
\text { lime } \\
\text { nematite } \\
\text { pyroxene } \\
\text { amorphous }\end{array}$ & $\begin{array}{l}\text { mincr: } \\
\text { melilite } \\
\text { periclise } \\
\text { hematite }\end{array}$ & $\begin{array}{l}\text { minor: } \\
\text { melilite } \\
\text { yuartz } \\
\text { amorphous }\end{array}$ & $\begin{array}{l}\text { minor: } \\
\text { lime } \\
\text { amorphous } \\
\text { trace: } \\
\text { anhydrite } \\
\text { melilite }\end{array}$ \\
\hline
\end{tabular}


Table 29. Crystalline phases identified in subbituminous deposits using $x-r a !$ diffraction. (phases listed in otder of decreasing abunlance)

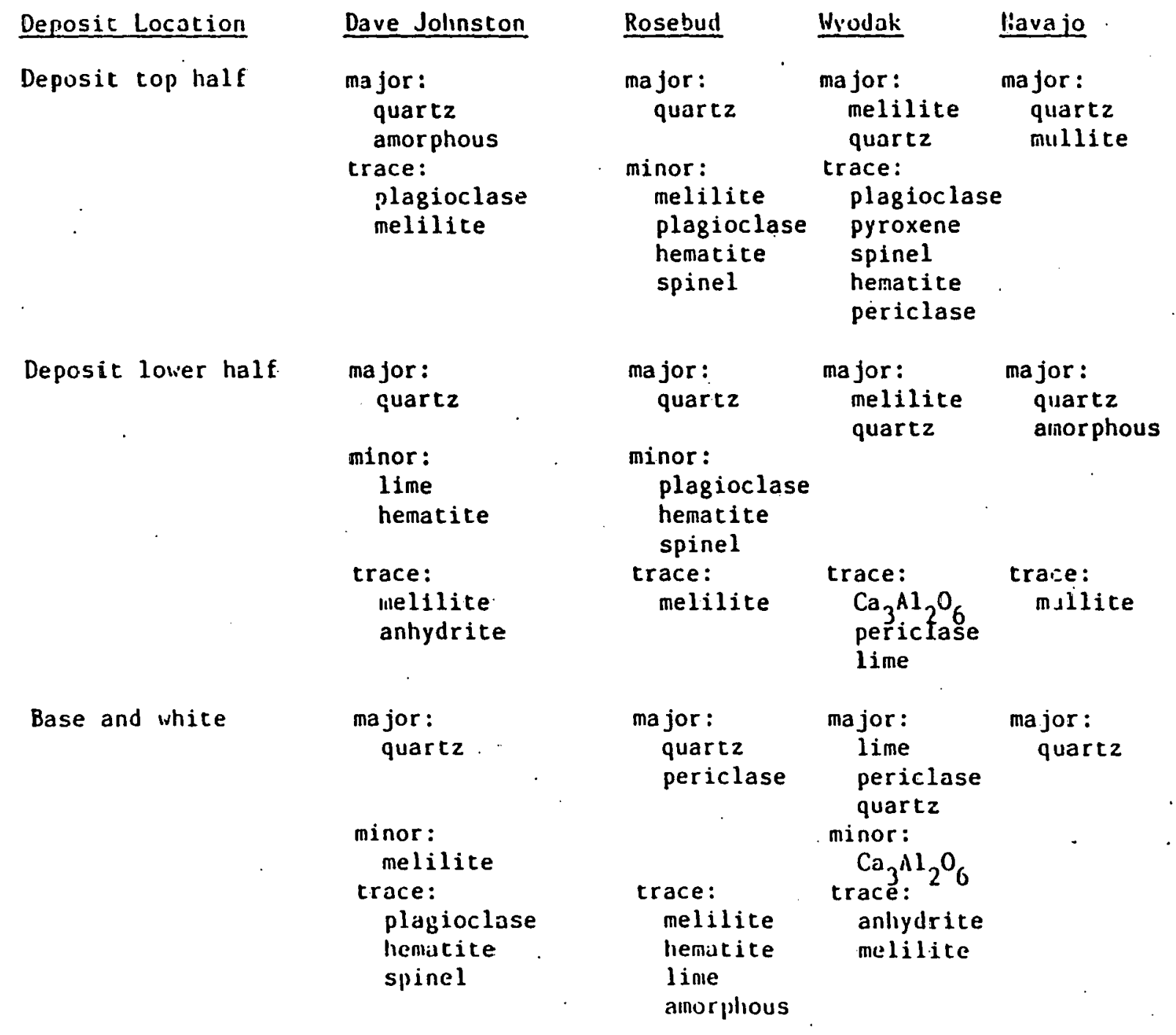


Table 30. Crystalline phases Identified in deposits produced from Rosebud and Rosebud float-sink fractions using $x$-ray diffraction.

(phases listed in order of decreasing abundanice)

\begin{tabular}{|c|c|c|c|c|}
\hline Deposit Location & Rosebud: & 1.4 Float & 1.6 Float & 1.6 Sirk \\
\hline \multirow[t]{2}{*}{$\begin{array}{c}\text { Deposit top and } \\
\text { lower halves }\end{array}$} & $\begin{array}{l}\text { ma jor: } \\
\quad \text { quartz }\end{array}$ & $\begin{array}{l}\text { ma jor: } \\
\text { melilite } \\
\text { plagioclase } \\
\text { quartz } \\
\text { periciase }\end{array}$ & $\begin{array}{l}\text { ma jor: } \\
\text { quartz } \\
\text { plagioclase } \\
\text { periclase }\end{array}$ & $\begin{array}{l}\text { major: } \\
\quad \text { quartz }\end{array}$ \\
\hline & $\begin{array}{l}\text { minor: } \\
\text { plagioclase } \\
\text { hematite } \\
\text { spinel } \\
\text { melilite }\end{array}$ & $\begin{array}{l}\text { minor: } \\
\text { pyroxene }\end{array}$ & $\begin{array}{l}\text { trace: } \\
\qquad \mathrm{Ca}_{3} \mathrm{Al}_{2} \mathrm{O}_{6}\end{array}$ & $\begin{array}{l}\text { minor: } \\
\text { hematite } \\
\text { trace: } \\
\text { magnetite }\end{array}$ \\
\hline \multirow[t]{2}{*}{ Base and white } & $\begin{array}{l}\text { major: } \\
\text { quartz } \\
\text { periclase }\end{array}$ & $\begin{array}{l}\text { ma jor: } \\
\text { periciase } \\
\text { quartz } \\
\text { minor: } \\
\text { amorphous }\end{array}$ & $\begin{array}{l}\text { major: } \\
\text { periclase } \\
\text { quartz }\end{array}$ & $\begin{array}{l}\text { major: } \\
\text { quartz } \\
\text { minor: } \\
\text { hematite }\end{array}$ \\
\hline & $\begin{array}{l}\text { trace: } \\
\text { melilite } \\
\text { hematite } \\
\text { lime }\end{array}$ & $\begin{array}{l}\text { trace: } \\
\qquad \mathrm{Fe}_{2} \mathrm{O}_{3}\end{array}$ & $\begin{array}{l}\text { trace: } \\
\qquad \mathrm{Fe}_{2} \mathrm{O}_{3}\end{array}$ & $\begin{array}{l}t=\text { ace: } \\
\quad \text { magnetite }\end{array}$ \\
\hline
\end{tabular}


Table 31. Crystalline phases identified in Texas lignite deposits using x-ray diffraction. (phases listed in order of decreasing abundance)

\begin{tabular}{|c|c|c|c|c|c|}
\hline Deposit Location & $\begin{array}{l}\text { San Miguel } \\
\left(1500^{\circ} \mathrm{C}\right)^{3 t}\end{array}$ & $\begin{array}{l}\text { I/E San Miguel } \\
\left(1500^{\circ} \mathrm{C}\right)\end{array}$ & $\begin{array}{l}\text { San Miguel } \\
\left(1400^{\circ} \mathrm{C}\right)\end{array}$ & $\begin{array}{l}\text { I/E San Miguel } \\
\left(1400^{\circ} \mathrm{C}\right)\end{array}$ & $\begin{array}{l}\text { Martin Lake } \\
\left(1500^{\circ} \mathrm{C}\right) \\
\end{array}$ \\
\hline \multirow[t]{2}{*}{ Deposit top half } & $\begin{array}{l}\text { ma jor : } \\
\quad \text { amorphous }\end{array}$ & $\begin{array}{l}\text { ma jor: } \\
\text { anorphous }\end{array}$ & $\begin{array}{l}\text { ma jor: } \\
\text { amor phous }\end{array}$ & $\begin{array}{l}\text { ma jor: } \\
\text { amorphous }\end{array}$ & $\begin{array}{l}\text { major: } \\
\text { plagioclase } \\
\text { melilite }\end{array}$ \\
\hline & $\begin{array}{l}\text { minor: } \\
\text { quartz }\end{array}$ & $\begin{array}{l}\text { minor: } \\
\quad \text { quartz }\end{array}$ & $\begin{array}{l}\text { minor: } \\
\quad \text { quartz }\end{array}$ & $\begin{array}{l}\text { minor: } \\
\quad \text { quartz }\end{array}$ & $\begin{array}{l}\text { pyroxene } \\
\text { minor: } \\
\text { quartz } \\
\text { amorphous }\end{array}$ \\
\hline \multirow[t]{2}{*}{ Deposit lower half } & $\begin{array}{l}\text { major: } \\
\text { amor phous }\end{array}$ & $\begin{array}{l}\text { ma.jor: } \\
\text { anorphous }\end{array}$ & $\begin{array}{l}\text { ma jor: } \\
\quad \text { amorphous }\end{array}$ & $\begin{array}{l}\text { major: } \\
\text { amorphous }\end{array}$ & $\begin{array}{l}\text { major: } \\
\text { periclase } \\
\text { lime }\end{array}$ \\
\hline & $\begin{array}{l}\text { minor: } \\
\text { quartz }\end{array}$ & $\begin{array}{l}\text { minor: } \\
\quad \text { quartz }\end{array}$ & $\begin{array}{l}\text { minor: } \\
\quad \text { quartz }\end{array}$ & $\begin{array}{l}\text { minor: } \\
\text { quartz }\end{array}$ & $\begin{array}{l}\text { minor: } \\
\text { hematite } \\
\text { quartz } \\
\text { amor phous }\end{array}$ \\
\hline Base and white & $\begin{array}{l}\text { major: } \\
\text { amor phous }\end{array}$ & $\begin{array}{l}\text { major: } \\
\text { amorphous }\end{array}$ & $\begin{array}{l}\text { major: } \\
\text { amorphous }\end{array}$ & $\begin{array}{l}\text { ma jor : } \\
\text { amorphous }\end{array}$ & $\begin{array}{l}\text { major: } \\
\text { periclase } \\
\text { quartz }\end{array}$ \\
\hline & $\begin{array}{l}\text { minor: } \\
\quad \text { quartz }\end{array}$ & $\begin{array}{l}\text { minor: } \\
\text { quartz }\end{array}$ & $\begin{array}{l}\text { minor: } \\
\quad \text { quartz }\end{array}$ & $\begin{array}{l}\text { minor: } \\
\quad \text { quartz }\end{array}$ & $\begin{array}{l}\text { minor: } \\
\text { lime } \\
\text { hernatite } \\
\text { amor phous }\end{array}$ \\
\hline
\end{tabular}

* - hot zone temperature. 
the fly ash material. 


\section{EFFECTS OF FURNACE CONDITIONS ON DEPOSIT FORMATION}

\section{Gas Velocity}

A test was performed using Upper Hiawatha \#1 coal to investigate the extent of deposition and properties of the deposit as affected by furnace parameters such as the gas velocity. The standard gas velocity $(3 \mathrm{~m} / \mathrm{s})$. was reduced to 0.6 $\mathrm{m} / \mathrm{s}$ by using a constrictor nozzle with a larger hole $(3.18 \mathrm{~cm}$ diameter). As shown in Table 32, the amount of the deposit formed from the low gas velocity condition was less than that formed at high gas velocity. The appearance of the deposit was also different. The only formation was a loosely deposited mass covering the entire substrate surface with no sign of fusing in the upper layers. No adherent material was noted after brushing off the loosely deposited material. These experiments demonstrate the influence of gas velocity on the deposit formation process; a drop in gas velocity would result in a decrease in the adhesion force.

\section{Constrictor Angle}

In order to reduce direct radiative heat transfer to the deposit, the constrictor nozzle was redesigned with the hole cut. at a $60^{\circ}$ angle to the horizontal. The deposit amounts are given in Table 33. The typical appearance of the deposit for the three 
Table 32. Deposit mass and percent ash recovered as deposit for test coals: total coal feed $-10 \mathrm{~g}$; feed time $=30 \mathrm{~min}$.

Coal

ASTM ash, Height of Deposit Ash recovered wt.\% deposit,cm mass, mg as deposit,\%

Normal constrictor $(1.27 \mathrm{~cm} \mathrm{dia.})^{a}$

U. HLawatha 非

9.4

1.4

568

60

Normal constrictor $(3.18 \mathrm{~cm} \mathrm{d1a.})^{\mathrm{b}}$

U. Hiawatha \#1

9.4

0.3

424

45 
Table 33. Deposit mass and percent ash recovered as deposit for test coals: total coal feed $=10 \mathrm{~g}$; feed time $=30 \mathrm{~min}$.

$\begin{array}{ccl}\text { ASTM ash, } & \text { Height of Deposit } & \text { Ash recovered } \\ \text { wt.\% } & \text { deposit,cm mass,mg as deposit,\% }\end{array}$

Normal constrictor $(1.27 \mathrm{~cm} \text { d12.) })^{a}$

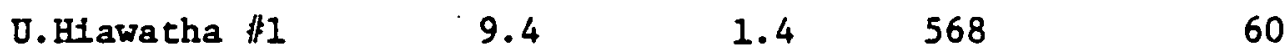

$\begin{array}{lllll}\text { Powder RIver Basin } & 4.6 & 1.0 & 320 & 65\end{array}$

$\begin{array}{lllll}\text { N. Dakota } & 7.1 & 1.3 & 367 & 52\end{array}$

$60^{\circ}$ angled constrictor $(1.27 \mathrm{~cm} \mathrm{dia.})^{a}$.

$\begin{array}{lllll}\text { U. Hiawatha \#1 } & 9.4 & 1.9 & 380 & 40\end{array}$

$\begin{array}{llllll}\text { Powder River Basin } 4.6 & 4.0 & 223 & 49\end{array}$

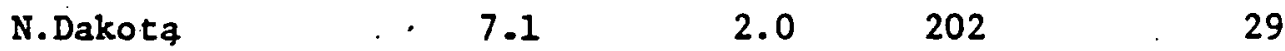


coals tested with this arrangement is shown in Figure 18 . As the deposit grows it bends the gas path to pass across the substrate disk, thus leading to deposition of larger particles in the "elbow" of the deposit, with smaller particles at the opposite side of the deposit.

Sodium sulfate crystals were found on the opposite side of the substrate from the deposit mass after tests with Upper Hiawatha \#1 and the North Dakota lignite. To confirm the possibility of sodium sulfate crystals depositing under these conditions, sodium sulfate powder (-38 micron) was passed through the furnace under otherwise similar experimental conditions. Crystal shapes and energy-dispersive $x$-ray fluorescence spectra of the deposit produced from sodium sulfate were similar to those for the deposits from the coals. The dust produced from the Powder River Basin coal contained a mass of needle-shaped crystals. The EDS of different areas of the dust indicated either calcium sulfate or a combination of sodium and calcium sulfates. Large, deformed particles of calcium sulfate were found in the elbows of the deposits from North Dakota lignite and Powder River Basin coal.

\section{Hot Zone Temperäure}

The effect of hot-zone temperature was determined in tests with Suite 2 coals. Center (North Dakota) and San Miguel (Texas) lignites were tested with hot zone temperatures of 1400 and 


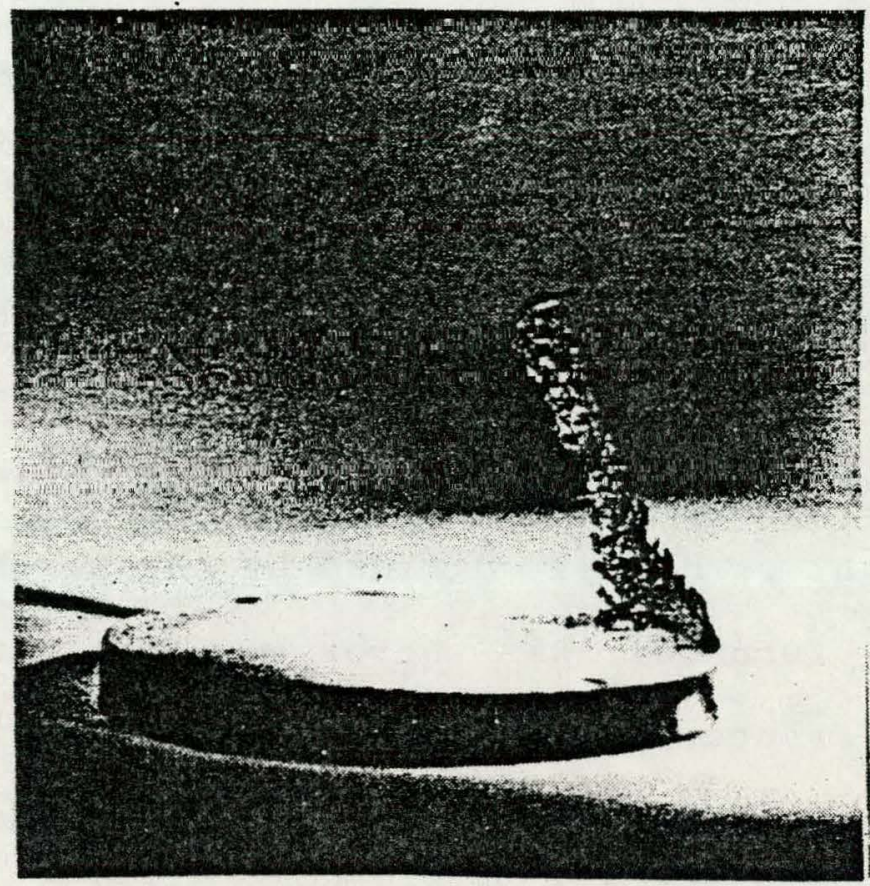

Etgure 18. Appearance of deposit from N.Dakota lignite ( $60^{\circ}$ angled constrictor). 
$1500^{\circ} \mathrm{C}$. There is a marked difference between the two temperatures in the amount of fused material in the deposit and in the crystaline phases present. San Miguel has a similar behavior. Pyroxene is the major crystalline species in the top of the Center deposit formed with a hot zone temperature of $1500^{\circ}$, but melilite is more abundant than pyroxene in the deposit from the 1400 . test.

Further tests were done to determine the effects of first removing the ion-exchangeable cations from these two lignites and then comparing the two hot zone temperatures. For the center lignite there was no appreciable difference in the deposit weight for tests at the two hot zone temperatures. However, for the San Miguel lignite a significant reduction in sticking fraction (the weight of deposit divided by the weight of ash in the coal fed to the furnace) was observed at the lower temperature. The difference in observed behavior of these two lignites and their ion-exchanged counterparts is likely attributable to the differences in the modes of incorporation of the inorganic constituents. This point is discussed in more detail later, in the subsection dealing with the growth of the deposit. 


\section{PHYSICS AND CHEMISTRY OF FLY ASH SINTERING}

This section discusses the thermophysical changesdevelopment of strength and shrinkage - and the chemical changes occurring during fly ash sintering. The experiments described in this section were performed in a special sintering furnace, to be described below, and not in the drop-tube furnace. This work therefore represents a collateral line of investigation to the main thrust of the combustion studies. However, an understanding of the sintering process is important for understanding the development of strength in the slag deposits, a phenomenon to be described in the following section. For that reason we digress from the discussion of combustion conditions and deposit formation to interject the results of fundamental studies of sintering studies, to set the stage for some of the later discussion of mechanisms of deposit formation.

The sintering of ash is an important part of the overall deposition process. Tests were performed in the present study for the specific purpose of evaluating the sintering characteristics of ash. The approach was to sinter fly ash pellets at various temperatures, times, and atmospheres to simulate the conditions at different locations within the deposit. After sintering, the sinter strength and extent of shrinkage were measured and chemical changes were monitored by $x$-ray diffraction. 
Soda-lime-silica glass (soda glass) is a homogeneous material which has been used as a model to study viscous flow sintering near $600 \circ \mathrm{C}, 1,3,6$ on the other hand, fly ash, in particular that from high-rank coals, is a heterogeneous material composed of low melting point components (glass) and high melting point components (crystalline materials). As a consequence, pure soda glass alone may not be a suitable model for comparison with the sintering of fly ash. A mixture of soda glass and alumina may more closely simulate a fly ash system. The soda glass used in this study had a composition of $75 \% \mathrm{SiO}_{2}, 8 \% \mathrm{CaO}$, and $17 \% \mathrm{Na}_{2} \mathrm{O}$.

sintering studies were conducted in a dedicated test system, shown in Figure 19. The furnace uses electrical resistance heating to attain a maximum temperature of $13000^{\circ} \mathrm{with}$ a rate of 6-8 per minute. The heating element is a platinum - $40 \%$ rhodium wire heated by a 120 volt, 10 amp variable power supply. The sample temperature was measured using a Type $S$ thermocouple (platinum / platinum-10\% rhodium) attached to the sample crucible.

To determine the sinter point, the material to be tested was loosely packed $\left(750 \mathrm{~kg} / \mathrm{m}^{3}\right)$ into a $10 \mathrm{~mm}$ diameter, $25 \mathrm{~mm} \mathrm{high}$ crucible. A $10 \mathrm{~mm}$ diameter, $0.5 \mathrm{~mm}$ thick disk of platinum foil was used as an electrode by placing it in the bottom of the sample crucible making contact with another platinum foil disk beneath the crucible; as part of an electrical circuit to measure the ash resistance. The platinum electrodes were connected to a 


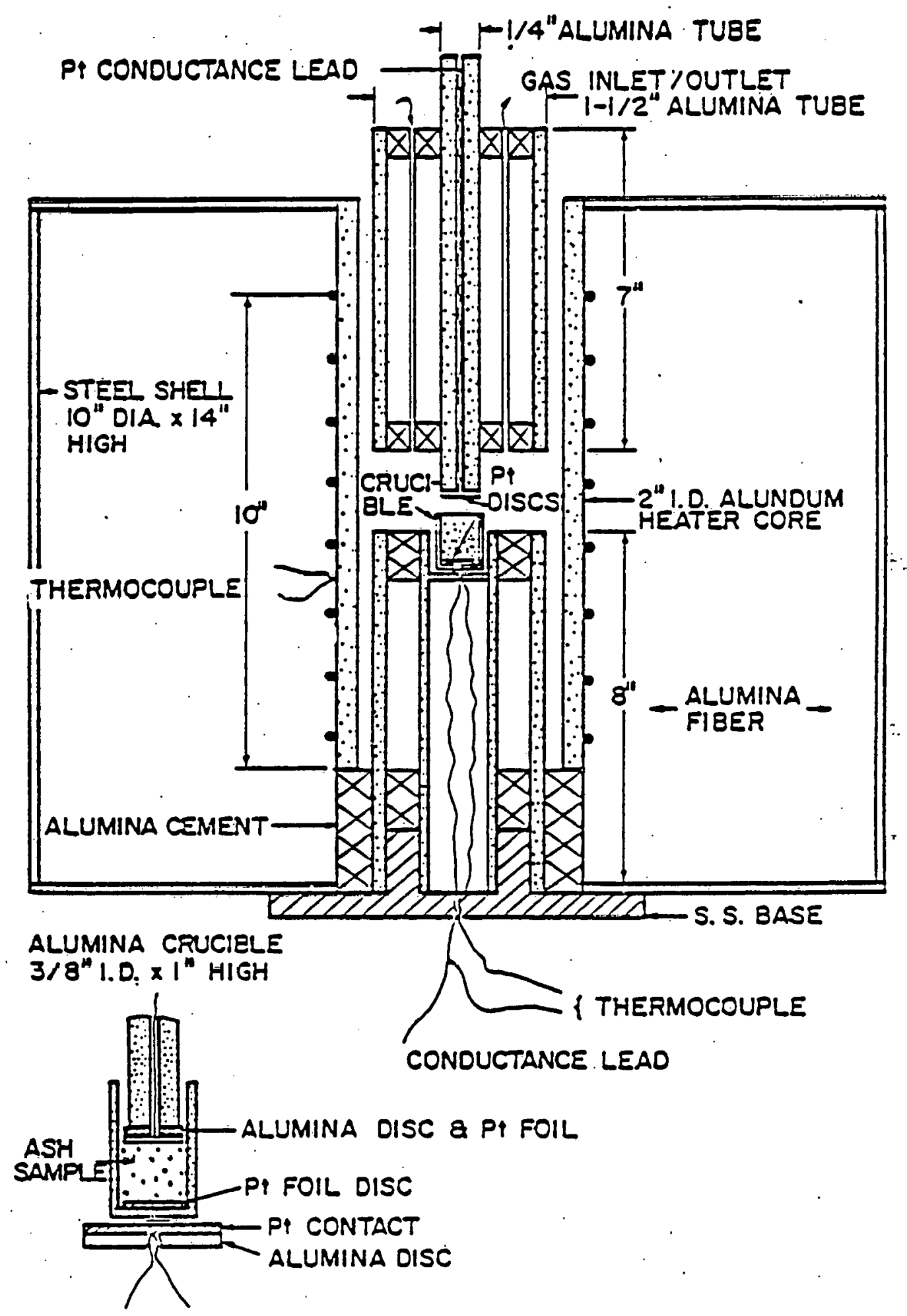

Figure 19. Ash sintering furnace. 
15 volt stabilized DC source. A 15 - 10,000 ohm variable, resistor was placed in one of the leads, and a potentiometric recorder was connected across the resistor. The ash resistance is related to the variable resistor setting and the voltage drop, as measured by a recorder, as a function of temperature. A plot of log resistance (R) versus $1 / T$ (absolute) normally gives a straight line, the slope of which changes as sintering commences. The temperature at the point of change in slope is called the electrical sinter point.

The Barnhart and Williams compressive strength test ${ }^{7}$ was modified by preparing an ash pellet having a bulk density comparable to that of the deposit in a boiler and using the conditions under which sintering in the radiant section takes place. To determine the compressive strength, a green pellet was made from $0.12 \mathrm{~g}$ of ash mixed with a drop of distilled water and compressed in a die at pressures sufficlent to give a $5 \mathrm{~mm}$ diameter, $5 \mathrm{~mm}$ high cylinder having a bulk density of $1200 \mathrm{~kg} / \mathrm{m}^{3}$. The pellet was put in a $10 \mathrm{~mm}$ diameter, $25 \mathrm{~mm}$ high alumina oruoible which was ieated in the sintering furnace at $8-8 \circ / 4 i n$ in air to the desired temperature and held at temperature for the desired time period. The pellet was allowed to cool to room temperature inside the furnace; cooling required approximately three hours. The diameter of the cold pellet was measured. The compressive strength determination was performed using an Instron appparatus. 
The compressive strength of the sintered ash pellet can be measured at room temperature after removal of the cold sintered pellet from the furnace or at high temperature by placing the furnace in the Instron apparatus. To determine strength at room temperature, the sintered pellet was placed on a flat $3 \times 4 \times 0.5$ inch stainless steel plate in the apparatus and crushed by raising it vertically against the load cell attachment. The output of the load cell. was read from a potentiometer. The compressive strength at high temperaturescan be determined by placing the furnace assembly in the Instron apparatus. By raising the furnace in the apparatus against the stationary alumina rod and load cell attachment, the load reading was then obtained. For tests performed in a reducing atmosphere, a $45 \%$ CO, 20\% $\mathrm{CO}_{2} ; 35 \%$ $\mathrm{H}_{2}$ mixture was introduced and removed through the alumina tube assembly. The other exits were sealed with high temperature fiber packing to prevent gas from leaking into the furnace. The gas flow was controlled at $400 \mathrm{~cm}^{3} / \mathrm{min}$.

The sinter point of pure soda glass was $525^{\circ} \mathrm{C}$. The alumina, which has a melting point of $2045^{\circ}$, gave a sinter point greater than $1200^{\circ}$. The mixture of soda glass and alumina exhibited a sinter point at $550^{\circ}$. This result indicates that the properties of soda glass are a determining factor in the sintering process. There was no development of strength in the heat treatment of alumina up to the maximum test temperature of 12000 , whereas strength development of the soda glass - alumina mixture began at $800^{\circ}$ and showed a small increase with temperature. This 
observation suggests that soda glass, which is the low melting point component, initiates and enables viscous flow sintering to occur at the low temperatures.

The effect of time on sintering was carried out using fly ashes from Upper Freeport and Beulah coals. The size distribution, ash fusion temperatures, spectrochemical, and mineralogical analyses of these ashes are given in Tables $34-$ 37.

The Upper Freeport pellets heated below the sinter point $\left(<800^{\circ}\right)$ did not develop strength, even after holding at the test temperature for several hours. No shrinkage was observed. The pellet remained as a loose powder when removed from the furnace, indicating that no sintering had occurred. The strength of the Upper Freeport pellets heated at $950^{\circ}$ and $1000^{\circ}$ (above the sinter point) increased with time from 15 minutes to 25 hours. As the heat treatment tomperature increased to 1nnno the slope of the compressive strength vs. time curve increased, showing that the rate of sintering increased with temperature. When the pellets were heated at even higher temperatures $(1050-11500)$, a maximum in strength was noted. The higher the heat treatment temperature, the shorter the time needed for develnping the maximum strength. For example, the maximum strength was developed in one hour at $1050^{\circ}$, as compared to 15 minutes at $1150^{\circ}$.

The Beulah fly ash had a sinter point of $550^{\circ} \mathrm{C}$. The strength 
Table 34. Size distributions (Microtrac) of test materials: fly ash

\begin{tabular}{|c|c|c|c|c|c|c|c|}
\hline Material & U.Freeport & Montour & I11. $\| 6$ & $\begin{array}{l}\text { I111nois } \| 6 \\
\text { gasifier ash }\end{array}$ & Beulah & $\begin{array}{c}\text { Water-washed } \\
\text { U.Freeport }\end{array}$ & $\begin{array}{l}\text { HF-washed } \\
\text { U.Freepor }\end{array}$ \\
\hline $\begin{array}{l}\text { Size } \\
(\mu \mathrm{m})\end{array}$ & & & Cumulative & t.\% less than & & & \\
\hline 44 & 100.0 & 100.0 & 100.0 & 100.0 & 100.0 & 100.0 & 100.0 \\
\hline 31 & 100.0 & 100.0 & 100.0 & 96.1 & 100.0 & 100.0 & 100.0 \\
\hline 22 & 100.0 & 100.0 & 100.0 & 89.1 & 80.6 & 100.0 & 96.8 \\
\hline 16. & 100.0 & 100.0 & 95.0 & 79.5 & 65.0 & 100.0 & 91.4 \\
\hline 11 & 95.2 & 84.3 & 72.2 & 68.2 & 52.4 & 96.9 & 83.9 \\
\hline 7.8 & 78.2 & 71.0 & 54.8 & 56.5 & 42.2 & 76.2 & 74.8 \\
\hline 5.5 & 64.3 & 59.9 & 41.7 & 45.5 & 34.0 & 59.9 & 64.9 \\
\hline 3.9 & 52.8 & 50.5 & 31.7 & 35.7 & $27.4^{-}$ & 47.1 & 54.9 \\
\hline 2.8 & 43.6 & 42.6 & 24.0 & 27.6 & 22.1 & 37.0 & 45.5 \\
\hline 2.0 & 35.5 & 35.9 & 18.3 & 21.0 & 17.8 & 29.1 & 37.1 \\
\hline 1.4 & 29.3 & 30.2 & 13.9 & 15.8 & 14.4 & 22.9 & .29 .8 \\
\hline 1.0 & 24.0 & 25.5 & 10.6 & 11.8 & 11.6 & 18.0 & 23.7 \\
\hline
\end{tabular}


Table 35. Size distributions (Microtra:) of test materials and additives.

\begin{tabular}{|c|c|c|c|c|c|c|}
\hline Materlal & $\begin{array}{l}\text { U.Freeport } \\
\text { min. m1x. }\end{array}$ & $\begin{array}{l}\text { Fused } \\
\text { D.Freeport } \\
\text { nin: mix. }\end{array}$ & $\begin{array}{l}\text { Iron } \\
\text { silfcate }\end{array}$ & $\begin{array}{l}\text { Calclum } \\
\text { sillcate }\end{array}$ & Pyrite & $\begin{array}{l}\text { Alumina } \\
\text { powder }\end{array}$ \\
\hline $\begin{array}{l}\text { Size } \\
(\mu \mathrm{m})\end{array}$ & & Cum & ative wt.\% & ss than si & & \\
\hline 44 & 100.0 & 100.0 & 100.0 & 100.0 & 100.0 & 100.0 \\
\hline 31 & 100.0 & 88.7 & 100.0 & 100.0 & 100.0 & 100.0 \\
\hline 22 & 100.0 & 74.5 & 95.3 & 90.9 & 93.7 & 100.0 \\
\hline 16 & 94.5 & 62.8 & 85.8 & 82.4 & 86.9 & 100.0 \\
\hline 11 . & 73.5 & 52.8 & 83.7 & 74.4 & 79.9 & 70.7 \\
\hline 7.8 & 57.1 & 44.4 & 77.1 & 67.0 & 72.9 & 50.0 \\
\hline 5.5 & 44.4 & 37.3 & 70.4 & 60.1 & 65.9 & 35.4 \\
\hline 3.9 & 34.5 & 31.4 & 63.7 & 53.9 & 59.2 & 25.0 \\
\hline 2.8 & 26.9 & 26.4 & 57.1 & 48.1 & 52.8 & 17.7 \\
\hline 2.0 & 21.1 & 22.2 & 50.8 & 42.9 & 46.9 & 12.5 \\
\hline 1.4 & 16.2 & 18.7 & 45.0 & 38.2 & 41.4 & 8.8 \\
\hline 1.0 & 12.6 & 15.7 & 39.5 & 33.9 & 36.4 & 6.3 \\
\hline
\end{tabular}


Table 36. Fuston temperature $\left({ }^{\circ} \mathrm{C}\right)$ of test materials.

\begin{tabular}{|c|c|c|c|c|c|c|c|c|c|}
\hline \multicolumn{3}{|c|}{ U.Freeport } & Montour & 111. & 116 & Beulah & Synthetic & Soda & \\
\hline $\begin{array}{l}\text { ASTM } \\
\text { ash }\end{array}$ & $\begin{array}{l}\text { F1y } \\
\text { ash }\end{array}$ & HF-washed & $\begin{array}{l}\operatorname{ASTM}^{*} \\
\text { ash }\end{array}$ & $\begin{array}{l}\text { ASTM } \\
\text { ash }\end{array}$ & $\begin{array}{l}\text { Fly } \\
\text { ash }\end{array}$ & $\begin{array}{l}\text { F1y } \\
\text { ash }\end{array}$ & $\begin{array}{l}M 1 n . \\
m 1 x .\end{array}$ & glass & $\begin{array}{r}\text { glass } \\
\text { a lumina } \\
(1: 1)\end{array}$ \\
\hline
\end{tabular}

Oxidizing

atmosphere

\section{Inttial}

deformat ton

$\begin{array}{lll}1390 & 1410 & 1420 \\ 1420 & 1480 & 1450 \\ 1450 & 1520 & 1460 \\ 1480 & 1520 & 1500\end{array}$

1430

1450

$1280 \quad 1220$

1200

1370

890

1340

Sof tening

1470

$1300 \quad 1250$

1220

1390

900

1370

Fluid.

1480

$1350 \quad 1280$

$1230 \quad 1420$

1160

1410

$\begin{array}{llll}1370 & 1290 & 1260 & 1460\end{array}$

1260

1460

Reducing

atmosphere

\section{Initial}

defial

$\begin{array}{lll}1200 & 1400 & 1400 \\ 1350 & 1440 & 1440 \\ 1420 & 1480 & 1470 \\ 1480 & 1520 & 1480\end{array}$

1240
1320
1360
1420

$1090 \quad 1110$

1070

1290

920

1280

Sof tening

$1120 \quad 1140$

1080

1400

950

1340

Hemisphere

$\begin{array}{lll}1480 & 1520 \quad 1480\end{array}$

$1140 \quad 1180$

1100

1420

1090

1410

Fluid

high temperature ASTH ash. 
Table 37. Spectrochemical analysis of test materials.

$\begin{array}{lllllll}\text { U. Freeport } & \text { Montour } & \text { Illinois } \# 6 & \text { Illinols \#6 Beulah } & \text { HF-washed } & \text { U.Freeport } \\ \text { fly ash } & \text { fly ash fly ash } & \text { gasifler } & \text { fly ash U. Freeport aynthetic }\end{array}$

Weight percert of equivalent oxides

\begin{tabular}{|c|c|c|c|c|c|c|c|}
\hline $\mathrm{SHO}_{2}$ & 53.5 & 51.1 & 44.7 & 46.5 & 28.8 & 34.9 & 58.0 \\
\hline $\mathrm{Al}_{2} \mathrm{O}_{3}$ & 28.2 & 27.7 & 19.7 & 20.3 & 14.8 & 42.7 & 24.8 \\
\hline $\mathrm{T} 10_{2}$ & 1.4 & 1.3 & 1.0 & 1.0 & 0.6 & 2.9 & 0.0 \\
\hline $\mathrm{Fe}_{2} \mathrm{O}_{3}$ & 6.3 & 10.5 & 15.7 & 16.0 & 14.6 & 14.1 & 11.6 \\
\hline MgO & 1.3 & 1.4 & 1.9 & 1.9 & 6.2 & 0.5 & 0.0 \\
\hline $\mathrm{CaO}$ & 3.1 & 2.3 & 5.1 & 5.2 & 20.4 & 0.1 & 0.8 \\
\hline Mno & 0.0 & 0.0 & 0.1 & 0.1 & 0.1 & 0.0 & 0.0 \\
\hline Sro & 0.0 & 0.0 & 0.1 & 0.0 & 0.7 & 0.0 & 0.0 \\
\hline $\mathrm{BaO}$ & 0.0 & 0.0 & 0.1 & 0.1 & 0.9 & 0.1 & 0.0 \\
\hline $\mathrm{Na}_{2} \mathrm{O}$ & 0.4 & 0.3 & 0.9 & 0.9 & 9.0 & 0.1 & 0.0 \\
\hline $\mathrm{K}_{2} \mathrm{O}$ & 2.9 & $2 . \mathrm{g}$ & 1.9. & 2.0 & 0.6 & 0.2 & 4.8 \\
\hline $\mathrm{P}_{2} \mathrm{O}_{5}$ & 0.5 & $0 . E$ & 0.5 & 0.0 & 0.3 & 0.0 & 0.0 \\
\hline $\mathrm{Zno}$ & 0.0 & 0.0 & 0.6 & 0.0 & 0.0 & 0.5 & 0.0 \\
\hline $\mathrm{SO}_{3}$ & 0.9 & 1.5 & 6.2 & 5.6 & 3.1 & 0.2 & $-\cdots$ \\
\hline Total & 98.0 & 98.0 & 98.2 & 100.0 & 100.0 & 9.5 .3 & 100.0 \\
\hline
\end{tabular}

${ }^{*}$ Source $=$ Mineral Constitution Laboratory, The Pennsylvania State University, Pa. 
of pellets heat treated at $950^{\circ}$ to $1050^{\circ}$ showed no significant increase and no shrinkage with time. At $11.500^{\circ}$, however, the strength of pellets increased with time and the pellets underwent some shrinkage. No maximum was noted in the strength of the Beulah fly ash, in contrast to the Upper Freeport ash. Presumably different sintering mechanisms were involved. The results of these tests suggest that the sintering time affects the sintering behavior, which in turn is dependent upon the heat treatment temperature and type of ash. The fly ash from high rank coal shows a greater effect than that from low-rank coal.

These tests showed that appreciable strength was achieved in a one hour heat treatment time in most cases. Thus one hour was chosen as a standard sintering time in subsequent tests to evaluate sintering as a function of temperature.

Compressive strength tests performed at room temperature on Upper Freeport fly ash sintered at $1150^{\circ} \mathrm{C}$ for one hour in air indicated linear stress with applied linear strain up to about. 10\% strain, followed by brittle fracture with a sudden large decrease of stress. At $700^{\circ}$ the failure strength was essentially the same, but there appeared to be enough ductility to require a higher strain to give failure. The fracture also was less explosive, so that the fall in stress as strain increased was less abrupt. At the heat treatment temperature of $1150 \circ$, the pellet deformed steadily to high strain, leading to a flattened peliet. This is clear evidence for the presence of a viscous 
liquid phase at temperatures above the sinter point. This. viscous liquid phase became solid at temperatures below the sinter point, causing no difference in the results of compressive strength between the test below the sinter point and the room temperature test.At the temperatures below the sinter point, solidification of the liquid phase and extensive sintered bond formation result in a strong pellet. In a boiler, as a deposit continues to build up, the temperatures of the inner deposit layer can cool to the extent that solidification of a viscuus liquid phase ean ocour. The sootblowers may then be ineffective in removing the strong deposit.

Further studies also-incorporated Montour and Illinois \#6 fly ashes; data on these ashes has been tabulated previously. The sinter points of Upper Freeport and Montour fly ash were identical $\left(800^{\circ} \mathrm{C}\right)$, whereas Illinois \#6 fly ash was slightly lower at $725^{\circ}$. Beulah fly ash showed by far the lowest sinter point at $550^{\circ}$. Strength development in the Beulah ash began at $400^{\circ}$ above the sinter point. X-ray diffraction analysis showed significant amounts of sodium and mixed alkall sulfates in the Beulah fly ash. These phases have low melting points that would give liquid ionic conduction at low temperatures and cause a change in the slope of $\log R$ vs $1 / T$. It is likely that the change in slope is not due to changes in particle geometry (e.g., growth of sinter necks), but due to the normal presence of a liquid phase formed at the sinter point. Fly ashes from high rank coals contain only traces of the alkali and mixed alkali sulfate phases, so higher 
temperatures were required to generate the liquid phase and cause a change in the slope of the plot. These fly. ashes started to develop strength at about 100 - $200^{\circ}$ above their sinter points.

Upper Freeport, Montour, and Illinois \#6 fly ashes showed a maximum in strength development as a function of heat treatment temperature. The maximum in strength corresponded to a maximum in shrinkage of the ash pellet. At heat treatment temperatures above that at which the maximum strength was developed, the shrinkage was not as great as it was at the temperature of maximum strength. Beulah fly ash showed a small increase in strength with temperature. No dimensional change was observed in Beulah fly ash pellets except for the pellet heat treated at $1150^{\circ}$.

SEM examination of Upper Freeport sintered pellets clearly indicated the development of sinter necks and the formation of a glassy phase. The maximum strength appears to be related to the greatest glass content in the pellet. $X$-ray diffraction analysis showed significant amounts of glass plus crystalline material such as quartz, hematite, and mullite. A postulated mechanism for the rise and subsequent fall of strength vs. temperature is as follows: At the temperature at which strength development begins (about $850^{\circ} \mathrm{C}$ for Upper Freeport), the low melting glass material originally present in the fly ash formed a liquid phase, enabling viscous flow sintering to occur. As the heat treatment temperature increased, the viscosity of the liquid decreased. In addition, the total amount of liquid probably increased from 
melting of higher melting point glass material and by dissolution of other high melting point components into the liquid phase. This resulted in the shrinkage of particles, followed by the growth of the larger ones, producing a structure of coalescence of round grains surrounded by a liquid, shown in Figure 20. Shrinkage and sintering at this stage proceeded rapidly because of the presence of sufficient liquid phase to fill the pores and because of the high mass transfer diffusion coefficient in a iiquid. The resulting matrix had a very high strength because the liquid phase produced a glass upon couling and gave assoeiated sintered bond formation in the heat treated pellet. The decrease in strength and reversal of shrinkage at the higher heat treatment temperatures (above 10500 for Upper Freeport) was associated with the formation of crystalline phases, particularly mullite. The content of crystalline phase appears to increase with temperature and a gradual decrease in glass content was observed. The formation of mulite could be a result of the thermal decomposition of the aluminosilicate glass, implying that some of the bonding glass was removed from the sintering mass. Since mullite has a melting point of $1810^{\circ} \mathrm{C}$, any mullite formed during sintering would remain as a crystalline solid at the heat treatment temperatures of 900 - 12000. The reduction in scrength at high temperatures is thus due to the reduction of the bonding glass phase by transformation of the glass into a crystalline phase. This transformation ralses the viscosity of the residual liquid and hence reduces the rate of sintering. 


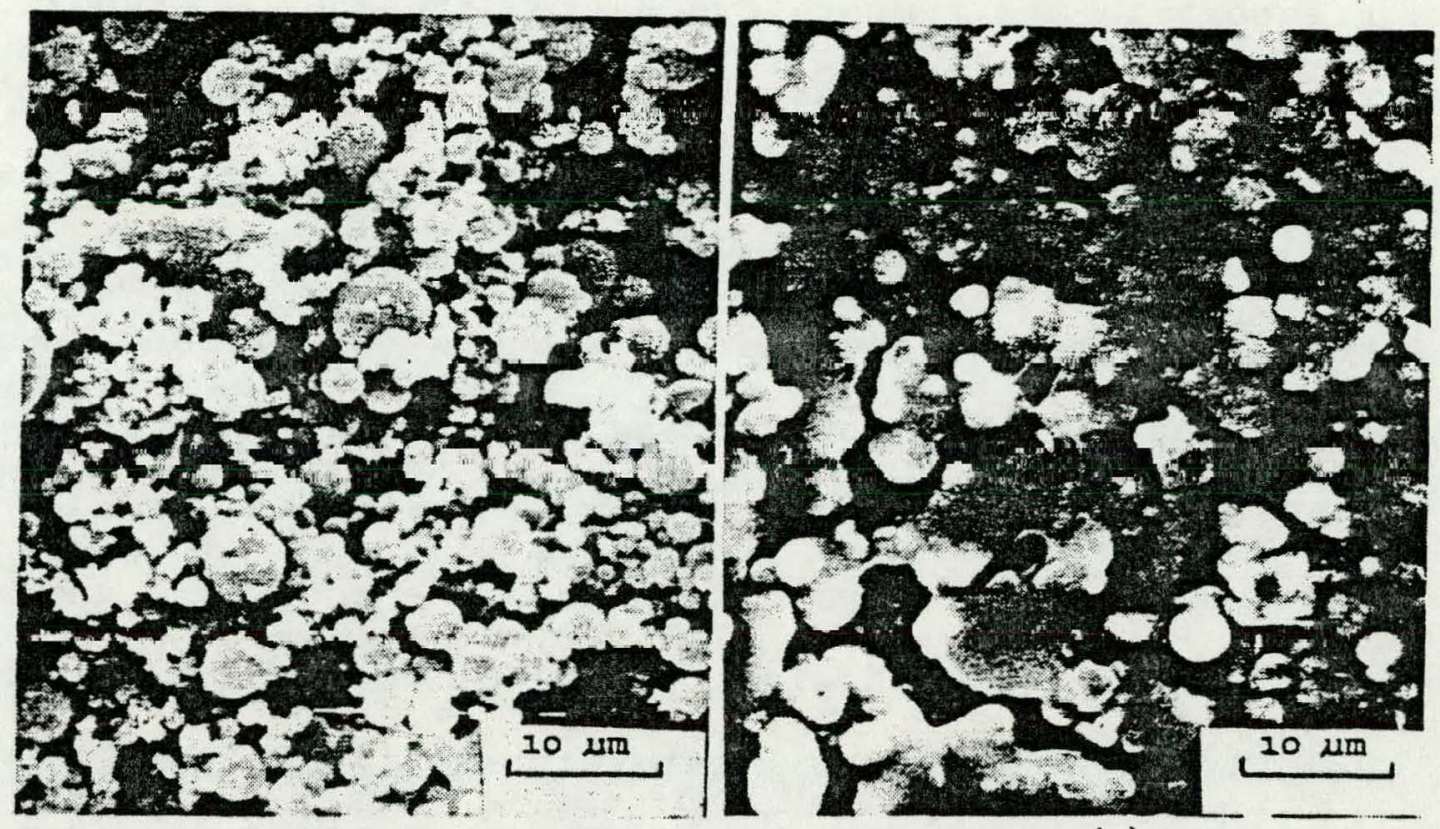

(a)

(b)

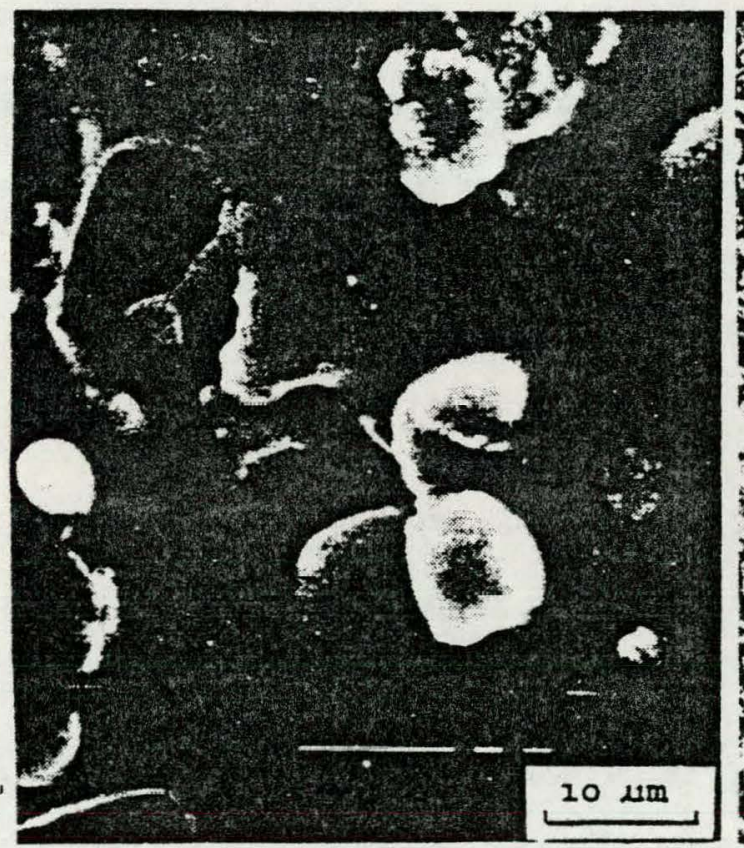

(c)

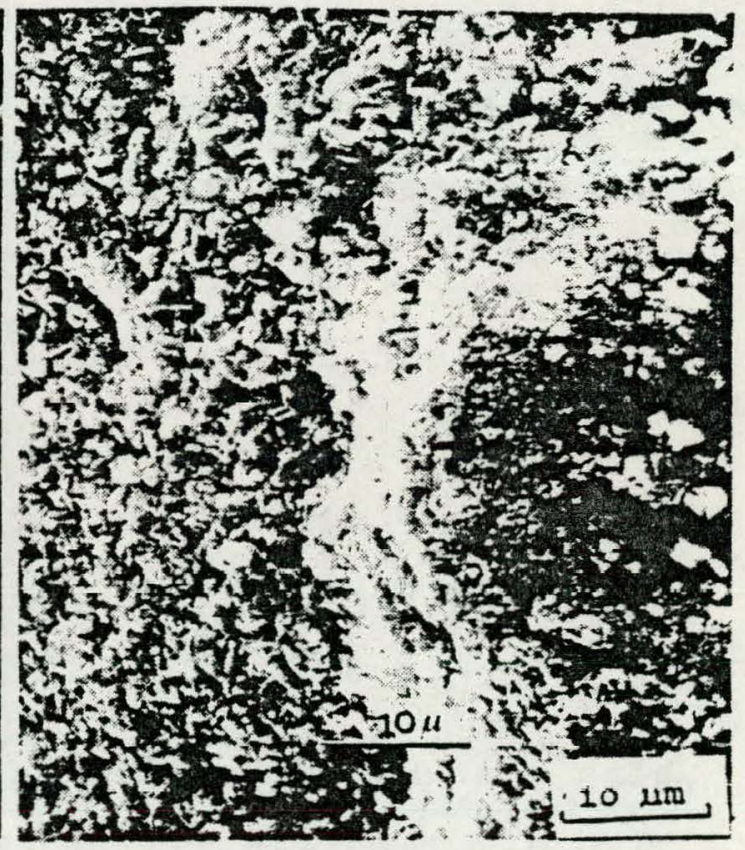

(d)

Figure 20. SEM photomicrographs of the structure of cold pellets from U.Freeport $f l y$ ash, as a function of heat treatment temperature for 1 hour in air,

(a) as received fly ash (after burning off carbon)

(b) sintered at $950{ }^{\circ} \mathrm{C}$; (c) sintered at $1050{ }^{\circ} \mathrm{C}$; and (d) sintered at $1200{ }^{\circ} \mathrm{C}$. 
Montour fly ash developed higher strength than Upper Freeport in the temperature range of $850-.1000^{\circ} \mathrm{C}$. A greater glass phase content was observed in the $x$-ray diffraction pattern of the Montour sintered pellet, compared to that of Upper Freeport, at $1000^{\circ}$. The high glass content in the Montour ash would indicate that large amounts of liquid phase formed. Sufficient liquid would bring most of the particles together and fill most of the pores, causing sintering to take place rapidly. The formation of crystalline phases - anorthite and mullite - in the Montour pellet again appears to correspond to the reduction. in strength at high temperatures $\left(>1000^{\circ}\right)$. The comparative sintering behavior of Upper Freeport and Montour fly ash is in accord with the utility experience using these two coals, since the Montour coal gives less problems with upper furnace sootblowing operation than Upper Freeport coal.

Fly ash from Illinois \#6 coal showed the same characteristic rise and fall of strength with temperature but gave the lowest maximum strength of any of the high-rank coal fly ashes tested. A significant amount of crystalline phase formation occurred at temperatures as low as $1000^{\circ} \mathrm{C}$, probably due to the relatively high content of calcium in this ash, which would readily interact with the glassy aluminosilicate phase to form crystalline anorthite. The formation of anorthite would readily remove the bonding glass and reduce the strength of the pellets. In this case the development of mullite crystals above $1050^{\circ}$ was not observed, suggesting that the bonding phase was largely removed 
by forming anorthite.

It is concluded from these observations that there probably exists two viscous flow mechanisms in the sintering of fly ashes from high-rank coals, one with a reactive liquid phase at low temperatures $\left(850-1050^{\circ} \mathrm{C}\right)$ and one with a non-reactive liquid phase at higher temperatures $(1050$ - 12000). As a result, the rise and fall of strength with temperature is a sintering characteristic of the fly ashes from high-rank coals.

The sintering characteristics of Beulah lignite fly ash exhibited a behavior different from those of the fly ashes from high-rank coals. Only a small increase in strength with temperature was observed. No maximum strength and no shrinkage occurred until the heat treatment temperature of $1150^{\circ}$. Crystalline phases in the sintered products were predominant over the glass material. The crystalline phases that formed at $950^{\circ}$ include the melilite series of minerals: gehlenite $\left(\mathrm{Ca}_{2} \mathrm{Al}_{2} \mathrm{Si}_{2} \mathrm{O}_{7}\right)$, sodium melilite $\left(\mathrm{NaCaAlSi}_{2} \mathrm{O}_{7}\right)$ and nepheline ( $\left.\mathrm{NaAlSiO}_{4}\right)$. As the heat treatment temperature increased, the $x$-ray diffraction peaks of the melilites increased in intensity. In addition, the sodalite minerals hauyne $(\mathrm{Na}, \mathrm{Ca})_{4-8}\left(\mathrm{Al}_{12} \mathrm{Si}_{12} \mathrm{O}_{24}\right)\left(\mathrm{SO}_{4}\right)_{2}$ and nosean $\mathrm{Na}_{8}\left(\mathrm{Al}_{6} \mathrm{Si}_{6} \mathrm{O}_{24}\right)^{\mathrm{SO}_{4}}$ were identified. Significant amounts of glass and alkali sulfates were detected in the as-received fly ash. These materials would, in principle, provide a liquid phase enabling sintering to occur. However, some of the liquid formed at the heat treatment temperature may have been quickly removed 
by interactions of the abundant alkali and alkaline earth sulfates and aluminosilicate glass to form crystalline phases. Thus the strength of pellets resulted mainly from the properties of the newly formed crystalline phases, i.e., from the formation of crystalline bridges between particles. These observations suggest that the sintering of fly ash from low-rank coals displays a viscous flow with non-reactive liquid phase mechanism under these conditions $\left(850-1150^{\circ}\right)$.

Melilites and sodalites have been found in the deposils formed in boilers firing high-sodium low-rank coals.8, It is thought that the strength resulting from the crystalline properties of these materials makes bonded deposits in boilers difficult to remove on-load. The results from this study are in accord with this earlier work. However, the observed sintering behavior of the Beulah fly ash under the conditions used in this investigation may not perfectly simulate the actual sintering behavior of bonded deposits in hoilers. In boilers there is a constant stream of alkali and sulfur oxide vapors in the flue gases which pass through the bonded deposit. These vapors could develop sufficient liquid phases from sodium and mixed alkali sulfates, sodium melilite and sodalites in the deposit matrix to enhance the sintering rate and make the bonded deposit stronger and harder than observed in this investigation.

In terms of analyzing the sintering process it is important to discern whether the formation of a liquid phase during 
sintering occurs from melting of some of the fly ash spheres, or is due to the surface of most spheres becoming liquid due to surface fluxing. Figure 21 shows the appearance of Upper Freeport fly ash washed with $10 \%$ hydrofluoric acid solution. The surfaces of the particles were etched, revealing the roughness of crystalline skeletons (probably mullite). The HF-washed ash did not develop appreciable strength or show shrinkage below $1150^{\circ}$. The lack of glass material on the surfaces of the HF-washed spheres and the resulting production of a weak deposit indicated that sintering occurs at the surface of most fly ash spheres.

The addition of calcium sulfate to the Upper Freeport fly ash reduced the strength of the sintered deposit. At $950{ }^{\circ} \mathrm{C}$ a significant amount of calcium sulfate was detected by $x-r a y$ diffraction, indicating that the calcium sulfate did not decompose and had no effect on the sintering behavior of the fly ash. However, at $1000^{\circ}$ the intensity of the calcium sulfate peaks started to decrease and anorthite was detected, showing a reaction with the aluminosilicate glass to produce anorthite. As the temperature increases, calcium sulfate and quartz disappeared, whereas anorthite increased. These phenomena appeared to be associated with the reduction in strength. The reaction between calcium sulfate and ash has been studied by thermogravimetric analysis.10 In a $1: 1$ calcium sulfate/ash mixture a weight loss was observed at $1000^{\circ}$ whereas calcium sulfate alone showed signs of weight loss only above $1300^{\circ}$. The temperature at which the calcium additive reacts with ash 

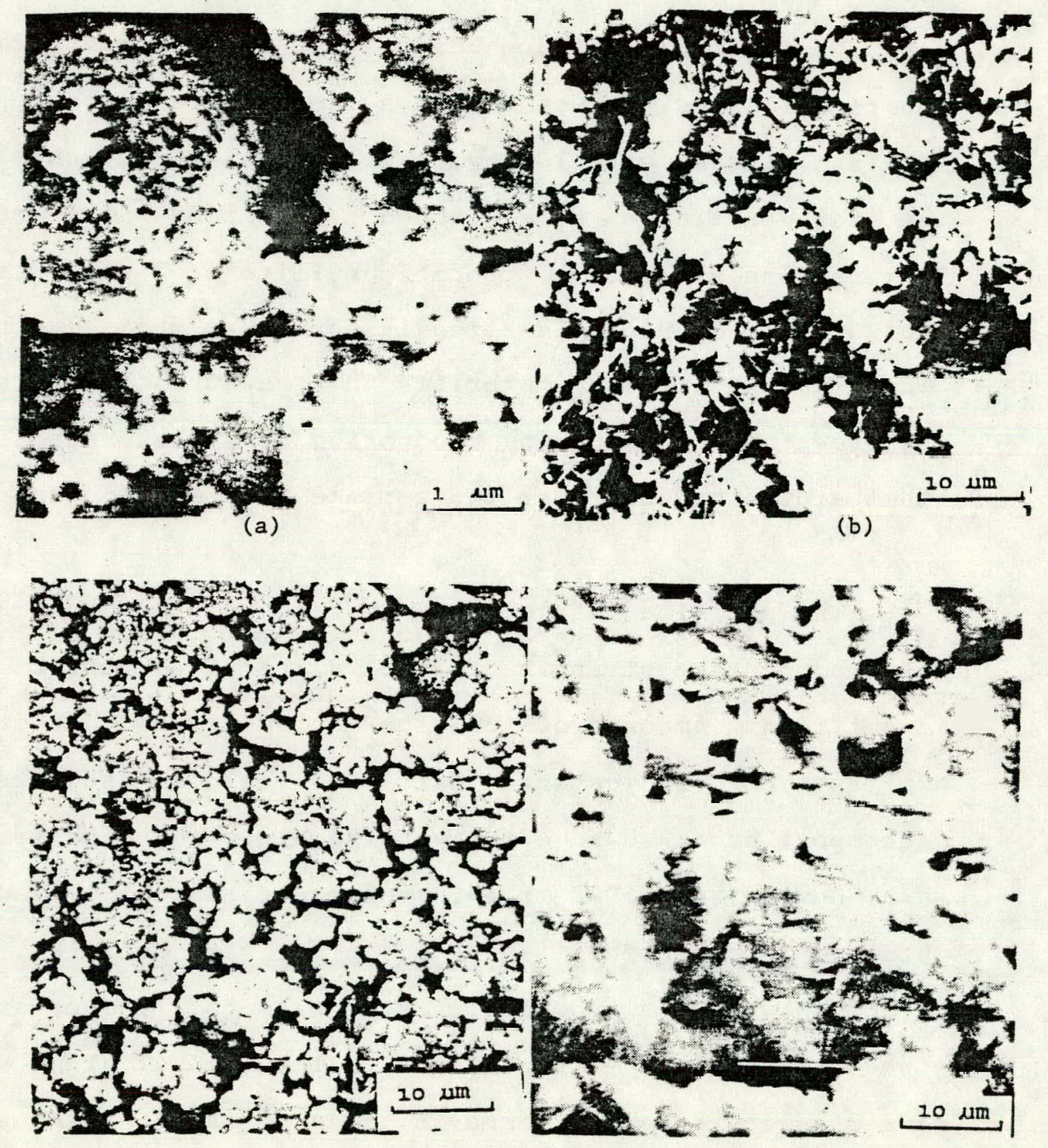

(c)

(d)

Figure 21. SEM photomicrograhps for the structure of cold pellets from HF-washed U.Freeport fly ash; (a) as received $\mathrm{HF}$-washed fly ash; (b) sintered at $950{ }^{\circ} \mathrm{C}$ for 1 hour in air; (c) sintered at $1100^{\circ} \mathrm{C}$ for 1 hour in air; and (d) sintered at $1150^{\circ} \mathrm{C}$ for 1 hour in air. 
components to reduce strength agrees with the thermogravimetric observations. It is also interesting to note that calcium carbonate has been shown to be an effective additive for reducing deposit strength in a full-scale boiler.11.

The foregoing evidence suggests that changes in quantity, viscosity, and composition of the glassy phase during sintering lead to changes in the rate of sintering. Therefore, either removing the glass material from the fly ash or increasing the crystalline phase in the matrix by using an additive could minimize the strength of sintered deposits formed in boilers. The laboratory method developed in this study could be used to determine the optimum additives and conditions of sintering. The appropriate additive and conditions could then be tested in an actual boiler to effectively reduce the deposit strength. 


\section{PROPOSED MECHANISM OF DEPOSIT FORMATION}

The formation of an ash or slag deposit on the heat transfer surfaces of a pulverized coal fired boiler can be explained by the following sequence of events:

1. Fly ash formation in the combustion zone and subsequent transportation of fly ash toward the heat transfer surfaco.

2. Initial adhesion of the ash particles onto the heat transfer surfaces.

3. Continued build-up of the deposit on the initial layer of adherent ash particles (the sticking process).

4. Interactions between the deposited ash particles to form a strong deposit matrix (the sintering process).

The findings of this project relevant to each of these events are presented and discussed in the sections which follow.

\section{Formation and Transportation of Ash Particles}

The transport of the ash particles from the high temperature gases onto the heat exchange surfaces either by inertial impaotion or by diffusion. The fastons determining which of these mechanisms is predominant are the size and mass of the ash particles, the flue gas velocity, and the aerodynamic conditions around the heat exchange surfaces.12 Large ash particles have a sufficiently large kinetic energy to leave the streamlines and 
impact on the surfaces they encounter. These impacting particles have an increased probability of adhesion because the kinetic energy of the particle is transformed to heat upon impact, possibly causing, or increasing the extent of, partial melting enough to increase the sticking behavior of the particle. The small ash particles or inorganic vapors move toward the surfaces by Brownian motion, by turbulent diffusion, or by thermophoretic diffusion through the temperature gradient in the boundary layer.

The upper part of the furnace is exposed to lower flue gas temperature than the lower part of the furnace. The ash droplets have cooled sufficiently so that thes might be expected not to deposit in this region. However, upper wall slags are known to exist and have been found to be enriched in certain fractions of the ash. The mechanism of formation of upper wall slag appears to be the selective deposition of specific inorganic species. Presumably the origin of these species is the result of the presence of low melting inorganic components of composition differing from the mean ash composition. Pilot-scale combustion of high rank bituminous coals showed that the deposition of ironrich ash particles in the upper wall regions occurs mainly by the inertial impaction process.13

\section{Adhesion of Ash Particles on Heat Exchange Surfaces}

The transport of ash particles to the heat exchange surfaces is not by itself sufficient to cause deposit formation if the 
particles are not retained on the surface after collision. The nature of the particle - surface interaction is determined by the physical and chemical properties of the ash particles and of the surface, the temperature, and the conditions of gas flow around or over the surface. The prime mode of deposition of the adherent particles is by inertial impaction. All other factors being equal, sticky or molten particles adhere more readily than solid particles. In a large pulverized coal fired boiler, supercooling of a molten ash droplet may occur due to a rapid cooling below its melting point withour the formatiun uf a solid phase: $A$ similar process may also occur on the surfaces of ash particles, forming a viscous, sticky surface glaze that can adhere and strongly bond to the boiler tube surfaces or stick to already adhered ash particles to form a strong deposit.

A coal with a low agh fucion temperature can he expented to give ash deposition problems. The ash fusion test (ASTM D-1857) has been used to provide a warning to boiler designers and operators about such coals. If ash particles arrive at heat exchange surfaces at a temperature below their fusion temperature, they will not form a bonded structure but instead will settle out as dust. Removal of these deposits by sootblowing is comparatively simple. On the other hand, if ash particles arrive at a heat transfer surface at a temperature at or higher than the fusion temperature, they will be very sticky and the resulting deposit will be tightly bonded, hard, and difficult to remove. 
The formation of a bond between an ash particle and boiler steel surfaces depends upon the composition and thermal behavior of the oxide layer on the steel. If the chemical composition of the ash particle is compatible with the oxide layer and the thermal properties are similar, the possibility of forming a strong bond is great. In addition, the surface tension and wetting ability of the particle when it reaches the steel surface influences its ability to flow across the steel, allowing interaction of the ash particle with the oxide layer. As will be discussed in detail below, the particles with the greatest strength of adhesion were rich in iron and silicon or iron and sulfur. Iron-containing silicates are known to wet readily most surfaces except carbon.14 The ternary phase diagram of the FeO$\mathrm{SiO}_{2}-\mathrm{Al}_{2} \mathrm{O}_{3}$ system ${ }^{25}$ indicates a low melting point region of $1200^{\circ} \mathrm{C}$, which is lower than the temperature of the gases passing through the constrictor. The phase diagram of FeO-Fes 14 indicates a eutectic melting as low as $930^{\circ} \mathrm{C}$; particles of this eutectic composition would likely be molten when the particle impacted the boiler steel surface.

Burner and wall slags occur in the lower part of the furnace where the metal temperatures of the waterwall tubes are the lowest. The lower part of the furnace around the flame is exposed to the highest rate of heat transfer and the hottest part of the flame, which will bring molten ash particles to the wall as liquid droplets. Drops of molten ash will not readily stick to 
the cool surface in this region unless the composition of the drops is rich in iron (from decomposition of pyrite), a characteristic which gives sticking and slag initiation at. relatively low metal temperatures. 1

Examination of the microstructure of a boiler wall slag with an electron microscope and microprobe showed that the slag region adjacent to the furnace wall consisted primarily of a glassy phase layer having high porosity, and that the slag region near the flame side contained a high proportion of crystalline phases and less porosity.16 The high proportion of glassy material next to the tube indicates that the first formed slag layer has been cooled rapidly to a temperature at which crystallization is insignificant.

In previous work sludying the adhesion behavior of ooal ashes on heat exchanger materials, it was postulated that it was nooebeary for the aurface ton have an oxide layer in order for adherence to occur.1 However, it was not conclusively shown that the bonding of the drop to the surface was via a chemical interaction, since alternative mechanisms might apply. It is known that the oxidation of a boiler steel in air produces an oxide layer with microporosity, and it is possible that flow of liquid material from the slag drop into these pores causes a mechanical anchoring after the drop has frozen. To test this alternative mechanism, an investigation of slag adherence on a reduced steel surface with high microporosity was conducted under 
a reducing atmosphere $\left(45 \% \mathrm{CO}, 25 \% \mathrm{CO}_{2}\right.$, and $\left.35 \% \mathrm{H}_{2}\right)$.

The sticking test was developed specifically to study those factors which influence the adhesion or non-adhesion of a drop of molten ash to a metallic substrate.17 The test consists of forming a $2 \mathrm{~mm}$ diameter $x 2 \mathrm{~mm}$ high pellet of powdered material around a small hook in the end of a $0.2 \mathrm{~mm}$ diameter platinum wire. The pellet is heated in the center of the three nozzle ring burner system shown in Figure 22. The flame is a methane - oxygen flame whose temperature can be varied by changing the relative flow rates of the methane and oxygen. As the pellet is heated it melts; when the viscosity is low enough a molten droplet falls off the wire. The droplet falls about $5 \mathrm{~cm}$ through the hole in the cap to the test substrate. (The cap shields the substrate from radiation from the flame, and enables the temperature of the substrate to be controlled accurately by an auxiliary electric furnace and small platinum heater.) The drop freezes on the substrate. The apparent contact angle is measured, and then the drop is sheared off the hot substrate by a ram connected to a force measurement system (shown in Figure 23). The test is repeated with identical pellets at increasing steps of substrate temperature.

The sticking test technique was previously tested on four coal ashes (prepared by the standard ASTM ashing procedure) using a methane - oxygen flame with an adiabatic flame temperature of $17500^{\circ} \mathrm{C}$ and a pre-oxidized mild steel substrate.18,19 It was 
TOP VIEW OF RING. BURNER

OXYGEN IN

METHANE IN

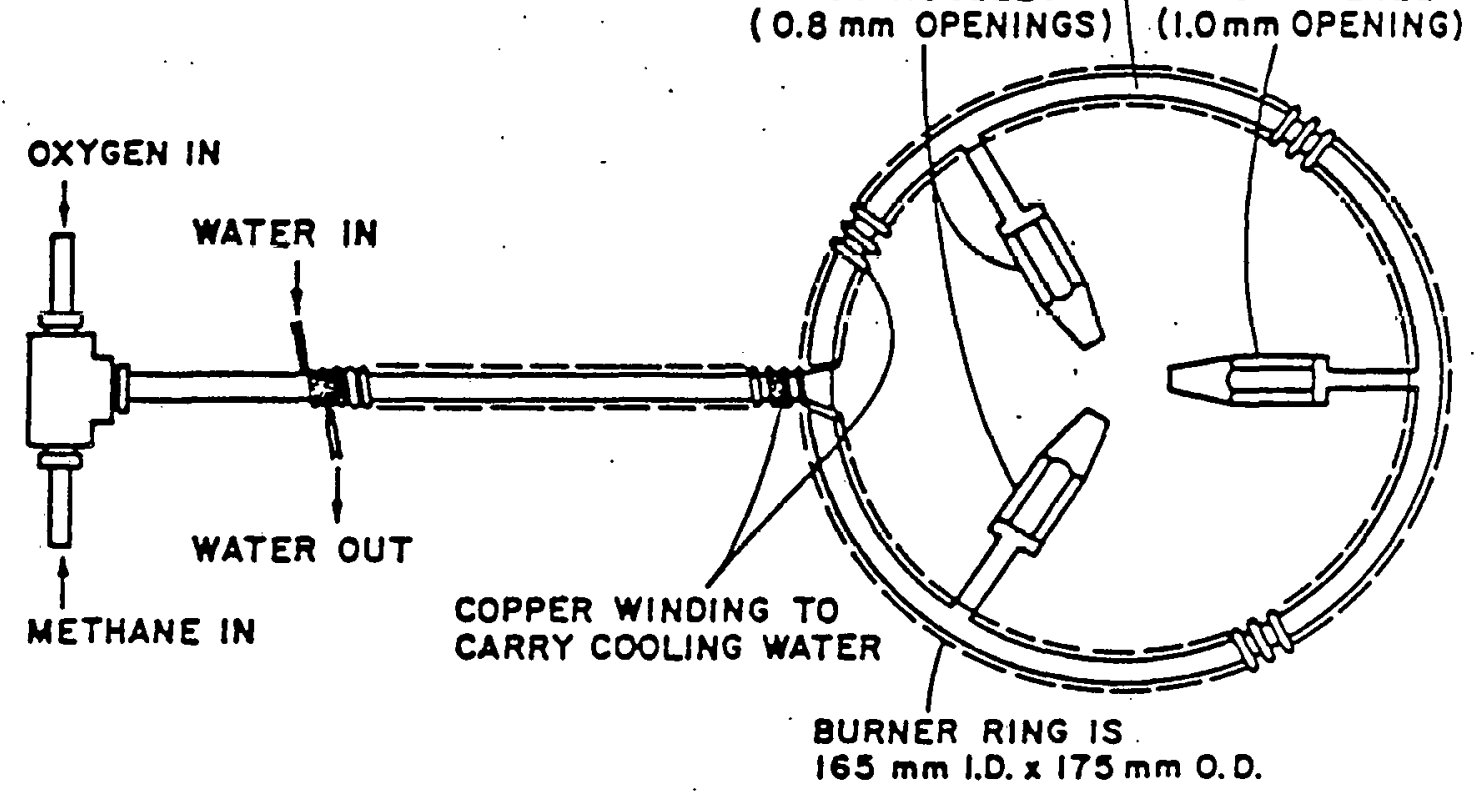

BRASS NOZZELS COPPER TUEING TO CARRY COMBUSTION GASES ( $9.5 \mathrm{~mm} \mathrm{O.D.)}$

BRASS NOZZLE

( $0.8 \mathrm{~mm}$ OPENINGS)

(1.0 $\mathrm{mm}$ OPENING)

SIDE VIEW OF

STICKING APPARATUS

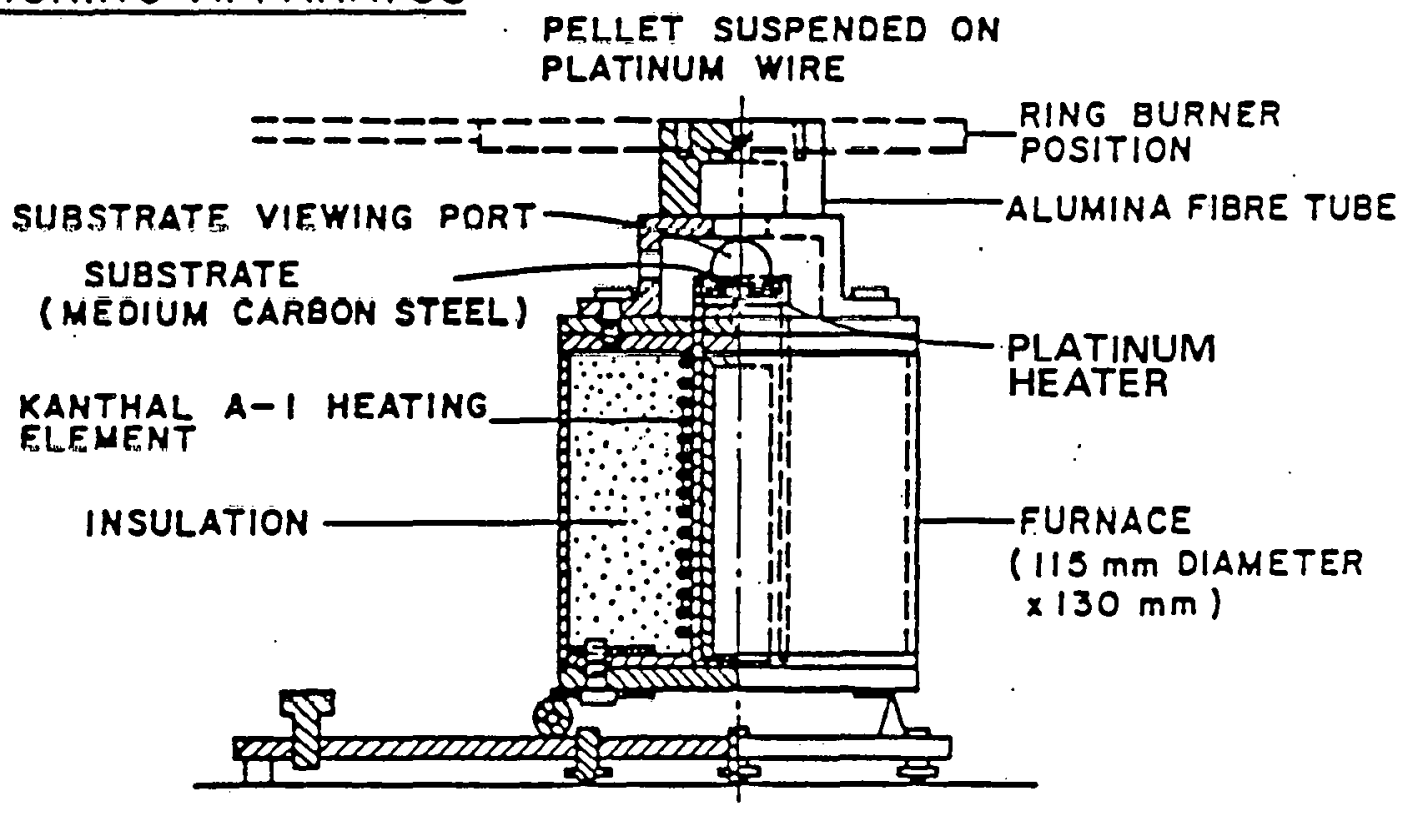

Figure 22. The sticking apparatus: diagram. 


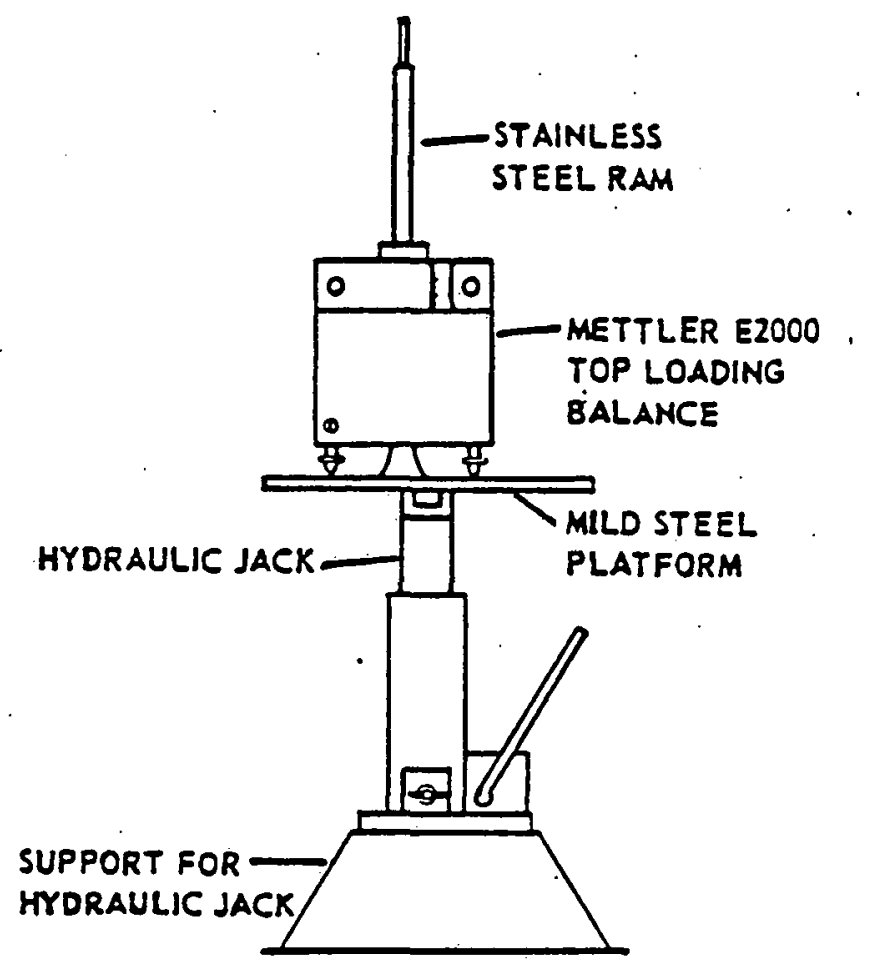

Figure 23. Device for measuring adhesion force. 
found that the drop would not adhere when the substrate temperature was below a critical temperature, called the sticking temperature. The sticking temperature was typically $425-5000 \mathrm{C}$, which is similar to the temperature of boiler wall tubes. Above this temperature, the adhesion strength increased roughly logarithmically with increasing substrate temperature. Although the behavior of the ash melted as a whole may not be a sufficient guide for the formation of slag deposits, the previous work did demonstrate a roughly quantitative method for the study of gahesion. 20

The sticking test procedure used in this investigation involved forming a pellet from low temperature ash (LTA ash), or from pure minerals or mineral mixtures ground to -38 microns. Ash or mineral pellets are made from a paste formed by mixing about 5 giuns of the ash or minerals with a drop of distilled water and two drops of $10 \%$ polyvingl alcohol solution, and then drying at $110 \circ$ C for one hour:

The substrate is a rectangular steel piece $35 \times 19 \times 6 \mathrm{~mm}$. A holc for a thermosouple (Pt / $10 \% \mathrm{Pt}-\mathrm{Rh}$ ) is drilled into the end of the substrate close to the upper surface. The thermocouple is held in place by belng casl in alumina cement. The pretreatment conditions were as follows: The substrates were first wet polished with $240,360,400$, and 600 grit silicon carbide papers. For tests under oxidizing conditions, the substrates were oxidized at $400^{\circ} \mathrm{C}$ for 20 hours in air. The investigation of slag 
adhesion on a reduced steel surface required a special pretreatment of the substrate: After the air oxidation just described, the substrate was then placed in the holder of the sticking apparatus and reduced with a flow of reducing gas mixture $\left(35 \% \mathrm{H}_{2}, 45 \% \mathrm{CO}\right.$, and $\left.20 \% \mathrm{CO}_{2}\right)$ at 500 o $\mathrm{C}$ for 72 hours.

The flame used to melt the pellet was fuel rich with a temperature of about $1600^{\circ} \mathrm{C}$ (measured by an optical pyrometer). The suspended pellet was held in the middle of the flame zone of the three nozzle ring burner until it melted and fell onto the substrate maintained at constant temperature. The adhesion force was measured by tilting the sticking furnace $900^{\circ}$ to determine whether the ash drop adhered under the force of gravity. If the ash drop stuck, the adhesion force was measured by bringing the ram of the adhesion force apparatus into contact with the drop and raising the ram until shear occurred.

The proximate and ultimate analyses, the analyses of the ASTM ash, the mineralogical analysis of the LTA, and the ash fusion temperature of the ASTM ash are given for the three tested coals in Tables $38,39,40$, and 41 , respectively.

Figure 24 shows SEM photomicrographs of the interface between an. Illinois \#6 LTA drop adhered to an oxidized type T-11 steel substrate in air. The drop wetted the oxide layer on the steel, giving a smooth interface between the drop and the steel. However, cooling to room temperature cracked the oxide layer from 
Table 38. Proximate and ultimate analyses ${ }^{*}$ of test coals.

$\begin{array}{lccc}\text { Coal } & \text { Pittsburgh } \# 8 & \text { Illinois } \# 6 & \text { U.Hiawatha } \$ 1 \\ \text { Moisture } & 2.00 \% & 6.83 \% & 6.36 \%\end{array}$

Proximate analysis (dry basis), wt.\%

$\begin{array}{llll}\text { Vol. matter } & 37.52 & 34.28 & 40.32 \\ \text { Ash } & 10.02 & .22 .32 & 11.49 \\ \text { Fixed carbon } & 52.46 & .43 .40 & .48 .19\end{array}$

U1cimate analysis (dry basis), wt.\%

$\begin{array}{lrrr}\text { Nltrogen } & 1.29 & 0.86 & 0.85 \\ \text { Carbon } & 72.80 & 58.10 & 69.70 \\ \text { Sulfur } & 2.00 & 4.96 & 0.45 \\ \text { Oxygen (diff.) } & 9.38 & 10.01 & 13.41 \\ \text { Ash } & 10.02 & 22.32 & 11.49\end{array}$

* Source = Mineral Constitution Laboratories, The Pennsylvania State University, PA.

Table 39. Chemical composition of ash of test coals: expressed as wr. \% nxides in high temperature ash (ASTM).

\begin{tabular}{|c|c|c|c|}
\hline Coal & P1etsbutgh \#8 & Illinois $\| 6$ & U. Hi awatha if \\
\hline HTA WE. $X$ & 9.9 & 19.7 & 10.9 \\
\hline $\mathrm{S} \mathrm{O}_{2}$ & 51.1 & 48.3 & 51.1 \\
\hline $\mathrm{Al}_{2} \mathrm{O}_{3}$ & 26.9 & 17.5 & 13.4 \\
\hline $\mathrm{T} \mathrm{O}_{2}$ & $\dot{u} \cdot \dot{y}$ & 0.8 & 0.9 \\
\hline $\mathrm{Fe}_{2} \mathrm{O}_{3}$ & 15.2 & 20.9 & $6: 2$ \\
\hline $\mathrm{CaO}$ & 0.9 & 4.7 & 14.1 \\
\hline $\mathrm{MgO}$ & 0.6 & 0.9 & 2.2 \\
\hline $\mathrm{Na}_{2} \mathrm{O}$ & 0.2 & 0.6 & 2.1 \\
\hline $\mathrm{K}_{2} \mathrm{O}$ & 2.2 & 1.6 & 0.8 \\
\hline $\mathrm{P}_{2} \mathrm{O}_{5}^{\circ}$ & 0.1 & 0.2 & 0.3 \\
\hline $\mathrm{SO}_{3}$ & 0.7 & 4.6 & 8.3 \\
\hline
\end{tabular}

* Source = Mineral Constitution Laboratories, The Pennsylvania State University, PA. 


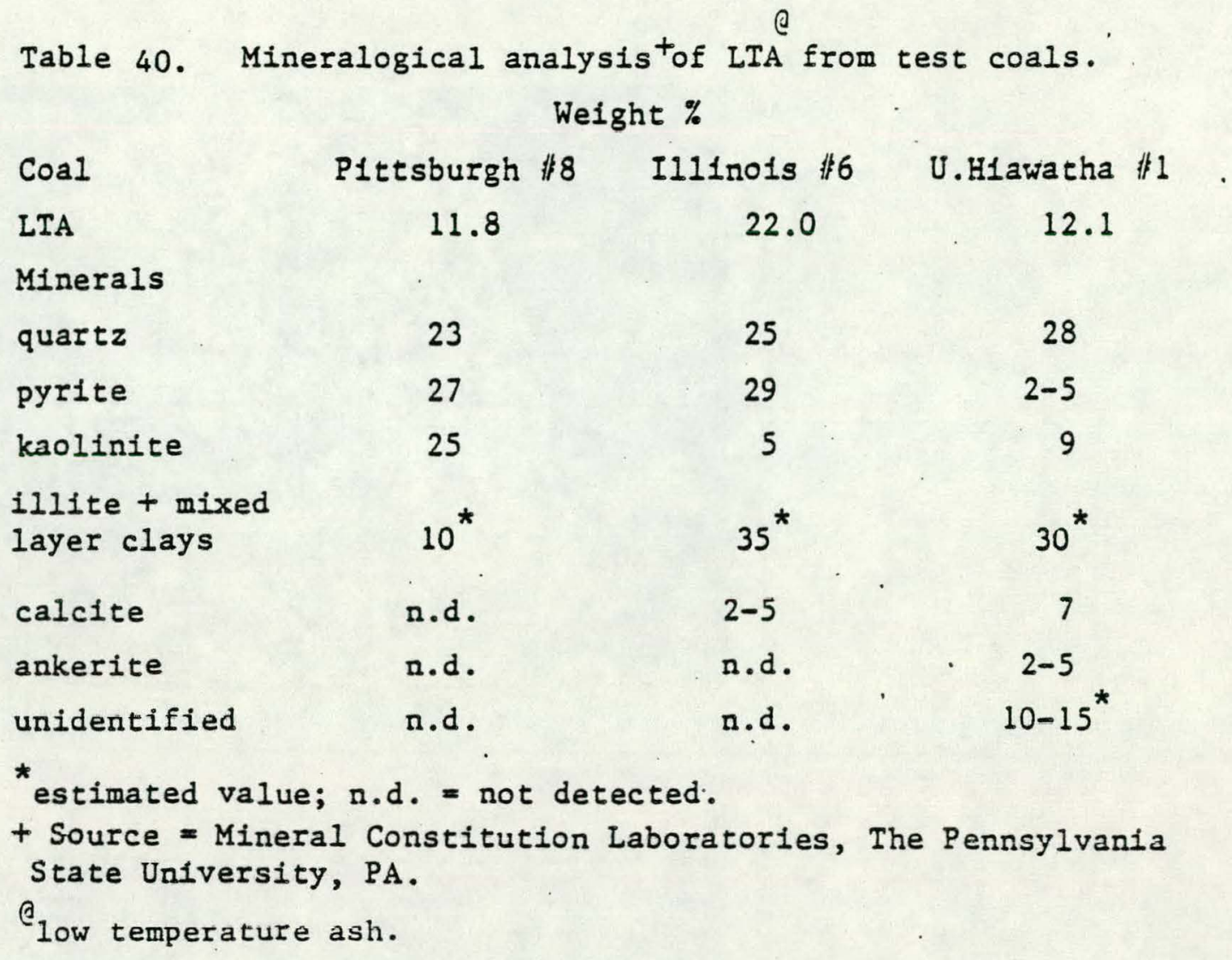

c

Table 41. Fusion temperature of HTA ash, ${ }^{\circ} \mathrm{C}$ from test coals.

Coal Pittsburgh \#8 Illinois \#6 U.Hiawatha 1

Oxidizing atmosphere

Initial

$\begin{array}{lccc}\text { deformation } & 1280 & 1430 & 1170 \\ \text { Softening } & 1300 & 1460 & 1180 \\ \text { Hemisphere } & 1350 & 1470 & 1220 \\ \text { Fluid } & 1370 & 1490 & 1310 \\ \text { Reducing atmosphere } & & & \\ \begin{array}{l}\text { Initial } \\ \text { deformation }\end{array} & 1090 & 1310 & 1120 \\ \text { Softening } & 1120 & 1330 & 1150 \\ \text { Hemisphere } & 1140 & 1370 & 1180 \\ \text { Fluid } & 1180 & 1420 & 1220 \\ \text { Q } & & & \end{array}$




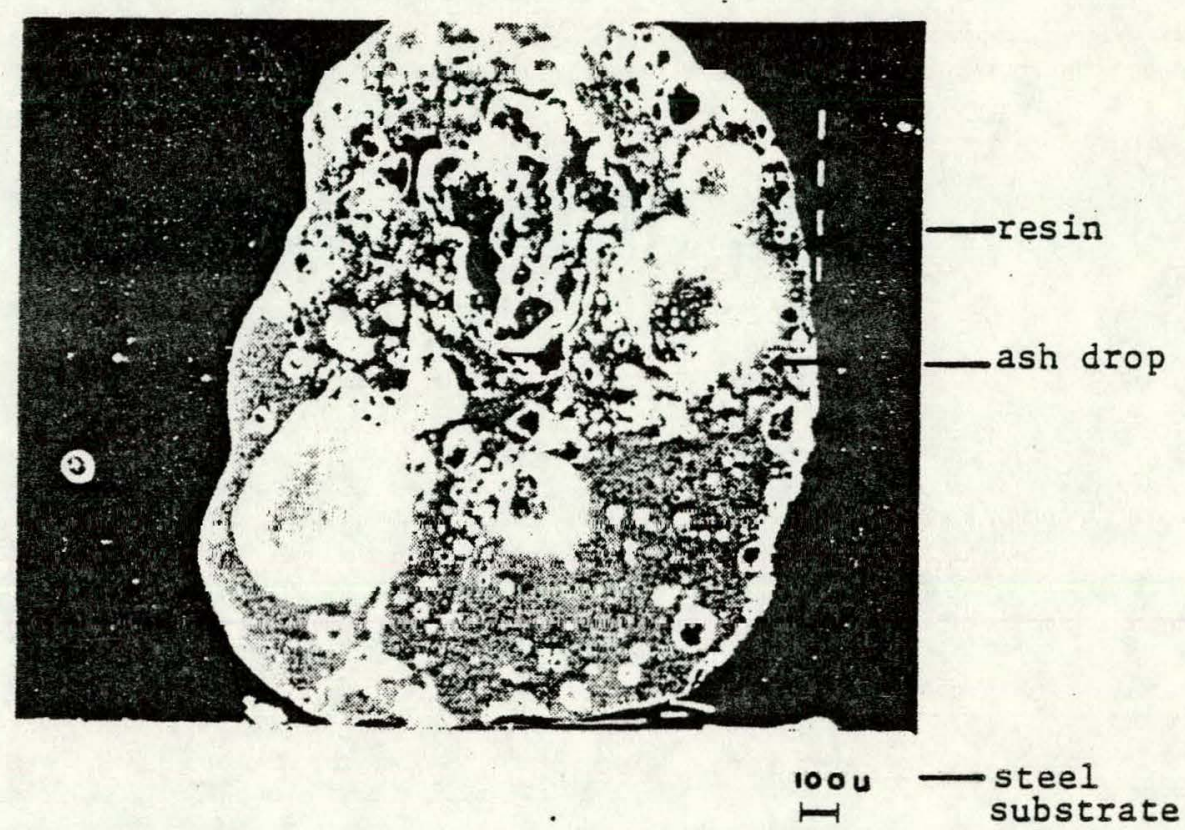

(a)

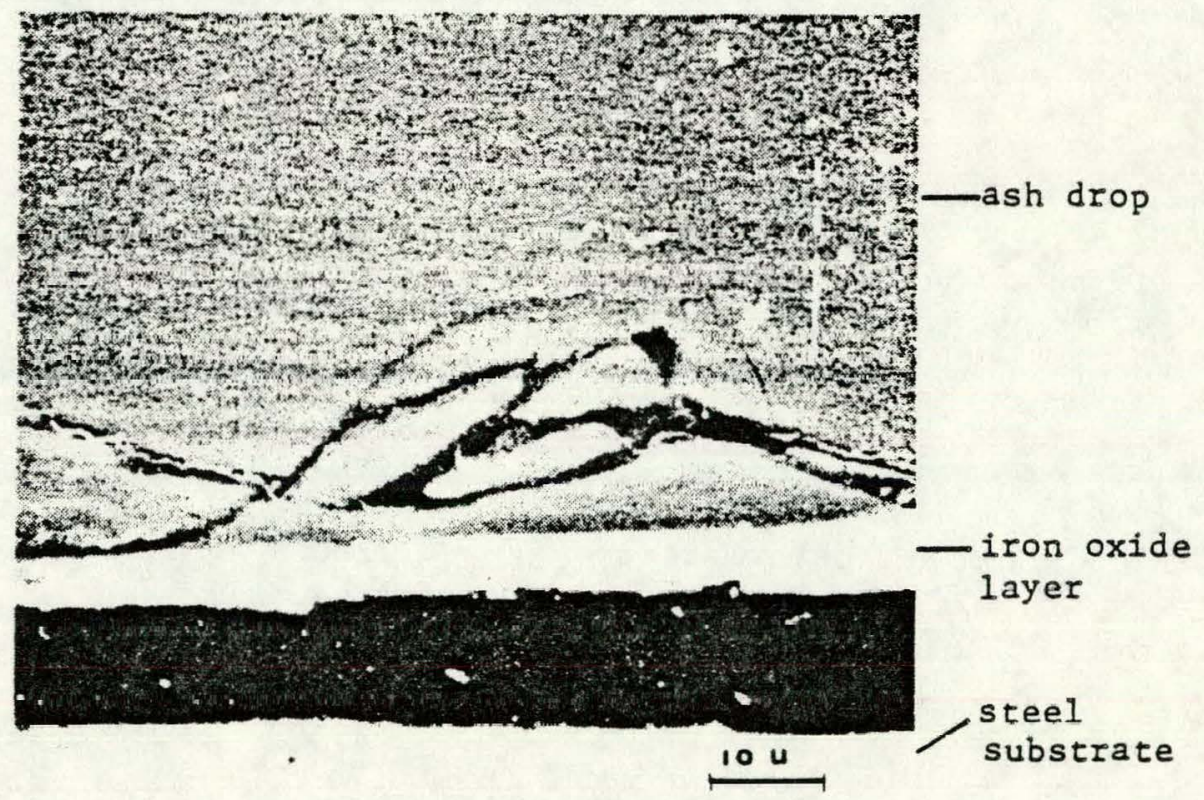

(b)

Figure 24. SEM photomicrographs showing cross-section characteristic of interface between Ililinois $\#_{6} 6$ LTA drop and oxidized T-11 steel substrate. Magnification of (b) fifty times that of (a). 
the steel. The drop cracked at the interface, demonstrating the high thermal stresses produced on cooling to room temperature. Figure 25 illustrates the results of an automated SEM-EDS analysis across the interface, indicating the gradual change in composition across the interface. Figure 26 shows the interface between the oxide layer and the drop. Figure 27 shows an iron map, with a low density of iron (plus holes) in the drop; Figure 28 shows a sulfur map, with no sulfur penetrating to the steel.

The SEM photomicrographs of the interface between an Illinois \#6 LTA drop adhered to oxidized stainless steel in air are illustrated in Figure 29. The appearance is similar to the adhesion on the oxidized $\mathrm{T}-11$, except that a substrate temperature of $600^{\circ} \mathrm{C}$ was necessary to develop a thin oxide film and to produce a significant adhesion strength.

Previous experience has shown that pyrite and $75 \%$ pyrite$25 \%$ clay mixtures gave strong adherence under oxidizing conditions.19 Figure 30 is the SEM photomicrographs showing the interface of a drop of $75 \%$ pyrite - $25 \%$ kaolinite mixture on oxidized $\mathrm{T}-11$ steel at $5000^{\circ} \mathrm{C}$. The drop wetted the oxide layer on the steel, giving a smooth interface between the drop and steel. A fracture was produced between the oxide layer and the steel upon cooling to room temperature. The drop also cracked at the interface. The SEM-EDS analysis revealed that the drop was very heterogeneous, since a layer containing only iron and sulfur existed at the bottom of the drop. 


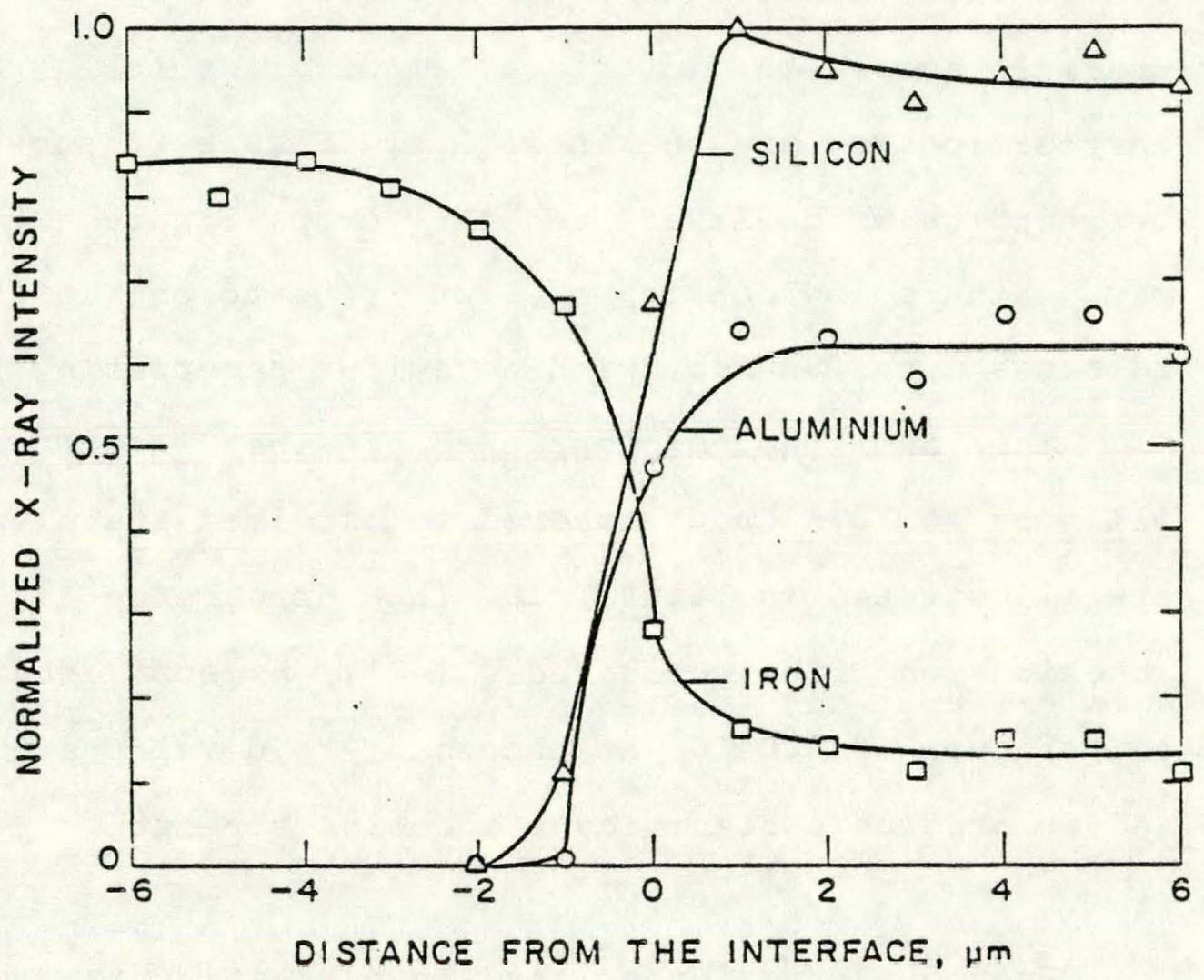

Figure 25. X-ray profiles of various elements as a function of distance from the interface, oxidized $T-11$ steel substrate at left and Tllinois $\$ 6$ LTA drop at right. 


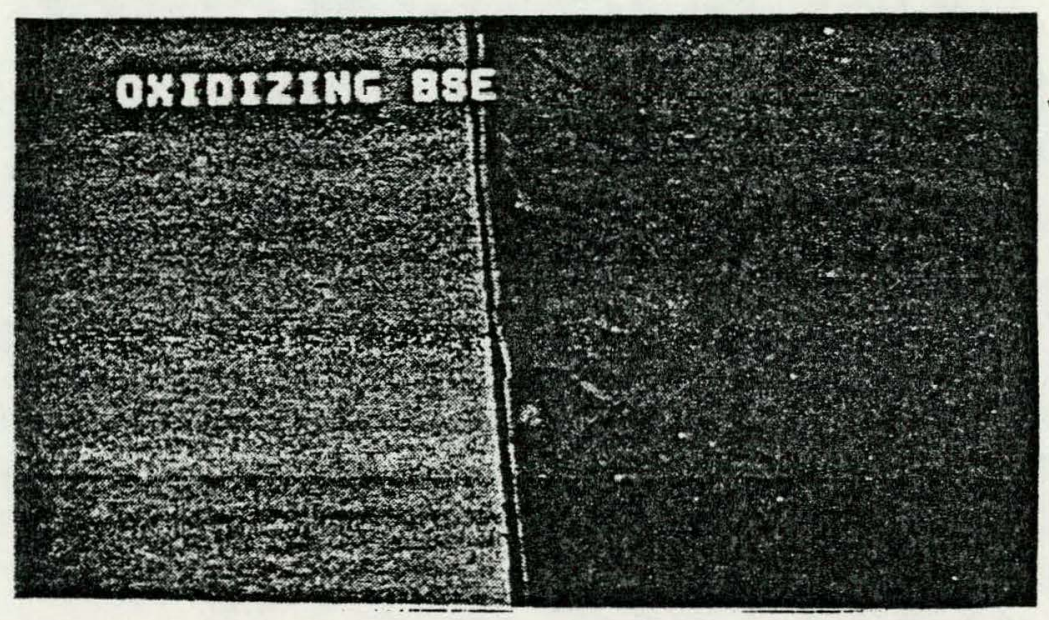

(a)

Figure 26. Backscattered electron image of interface between Illinois 非 drop (at right) and oxidized T-11 steel substrate (at left). 


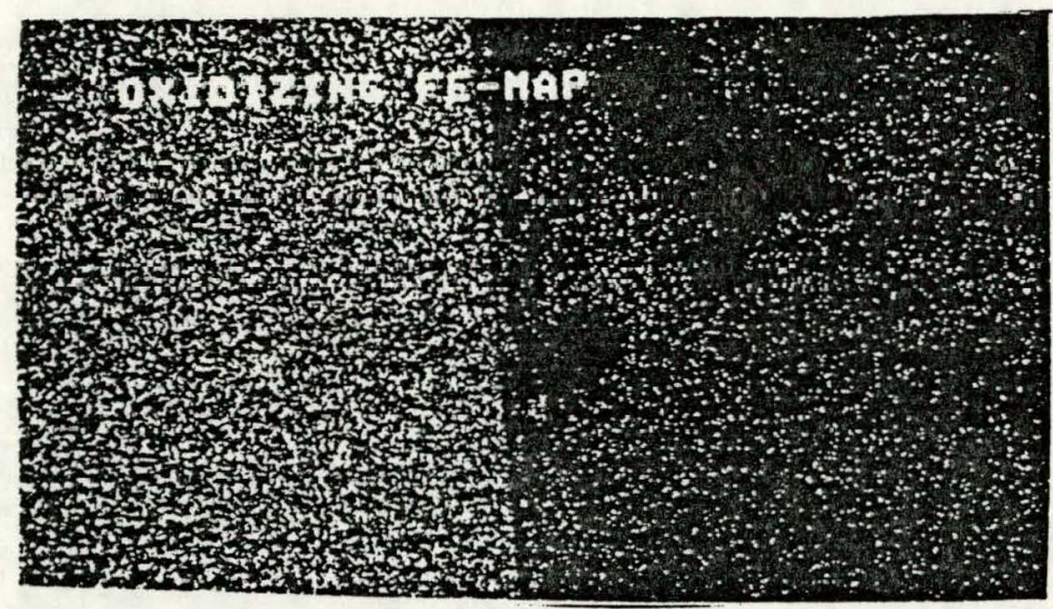

(b)

Figure 27. Iron $x$-ray mapping of interface shown in Figure 26. 


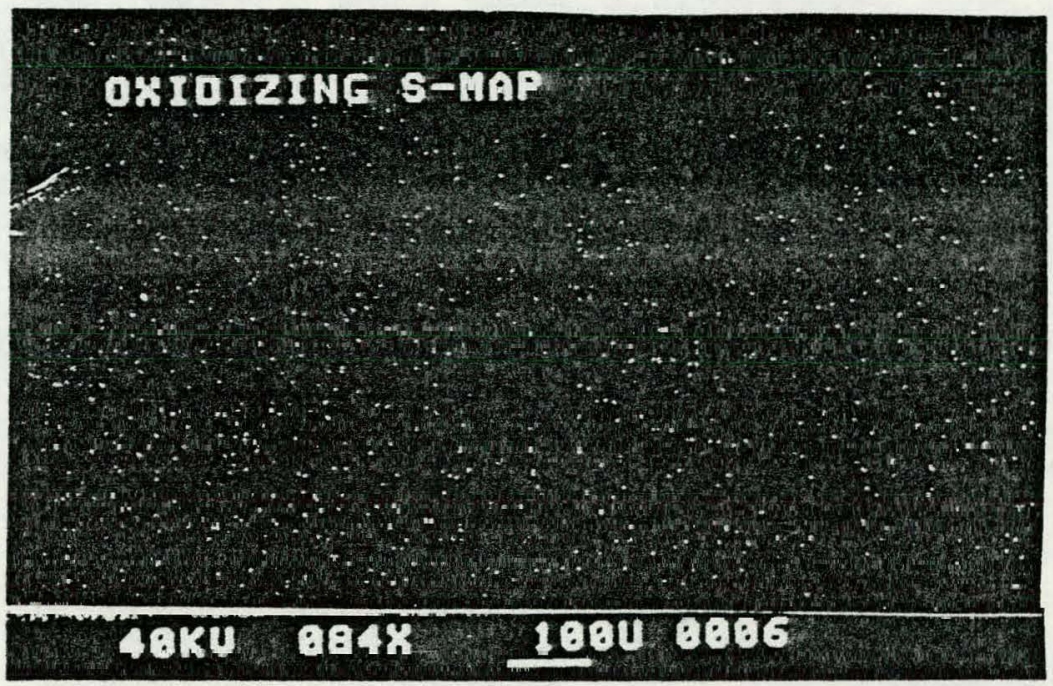

(c)

Back scattered electron (a) and the corresponding iron $x$-ray mapping (b) and sulfur mapping (c), showing cross-section characteristic of the interface between Illinois \#6 drop (at right) and oxidized T-11 steel substrate (at left).

Figure 28. Sulfur $x$-ray mapping of interface shown in Figure 26. 


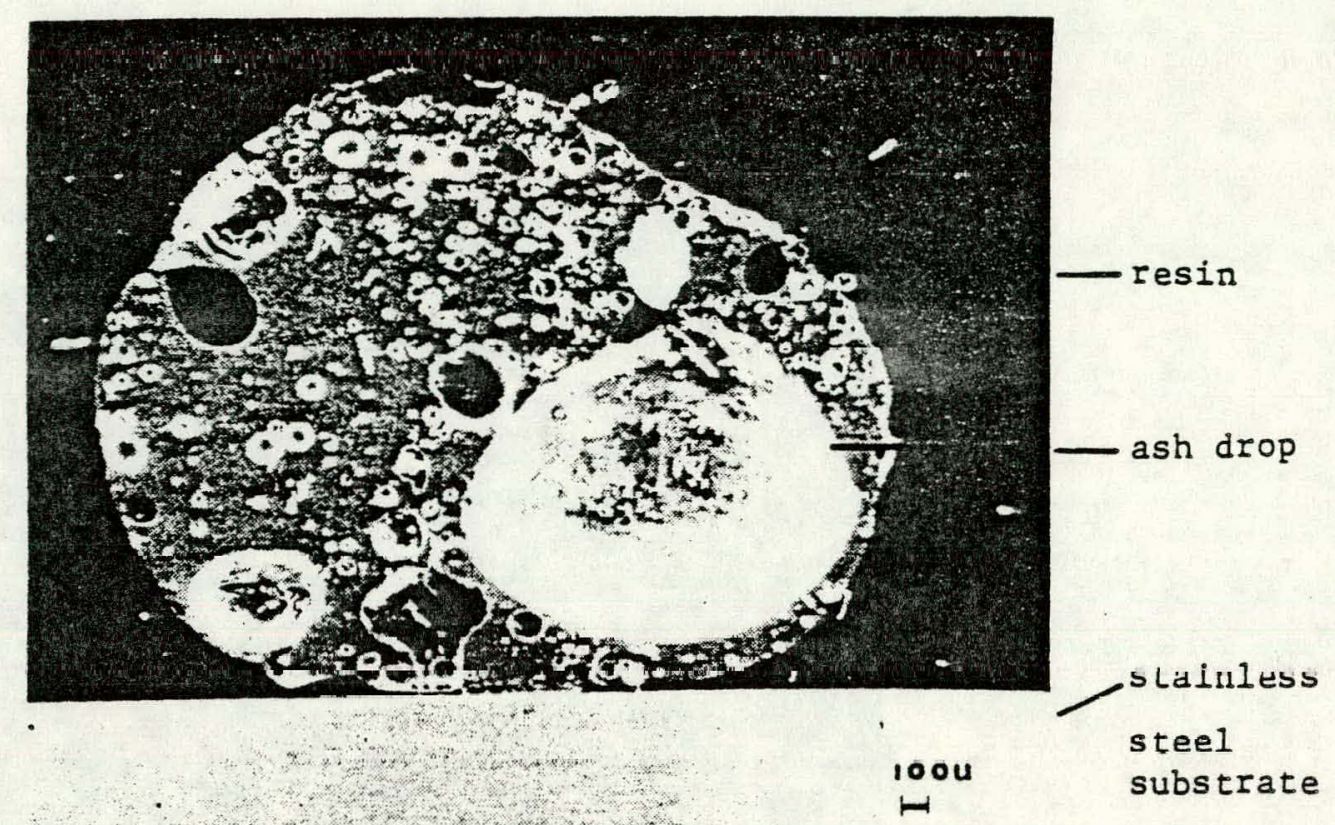

H.w.

(a)

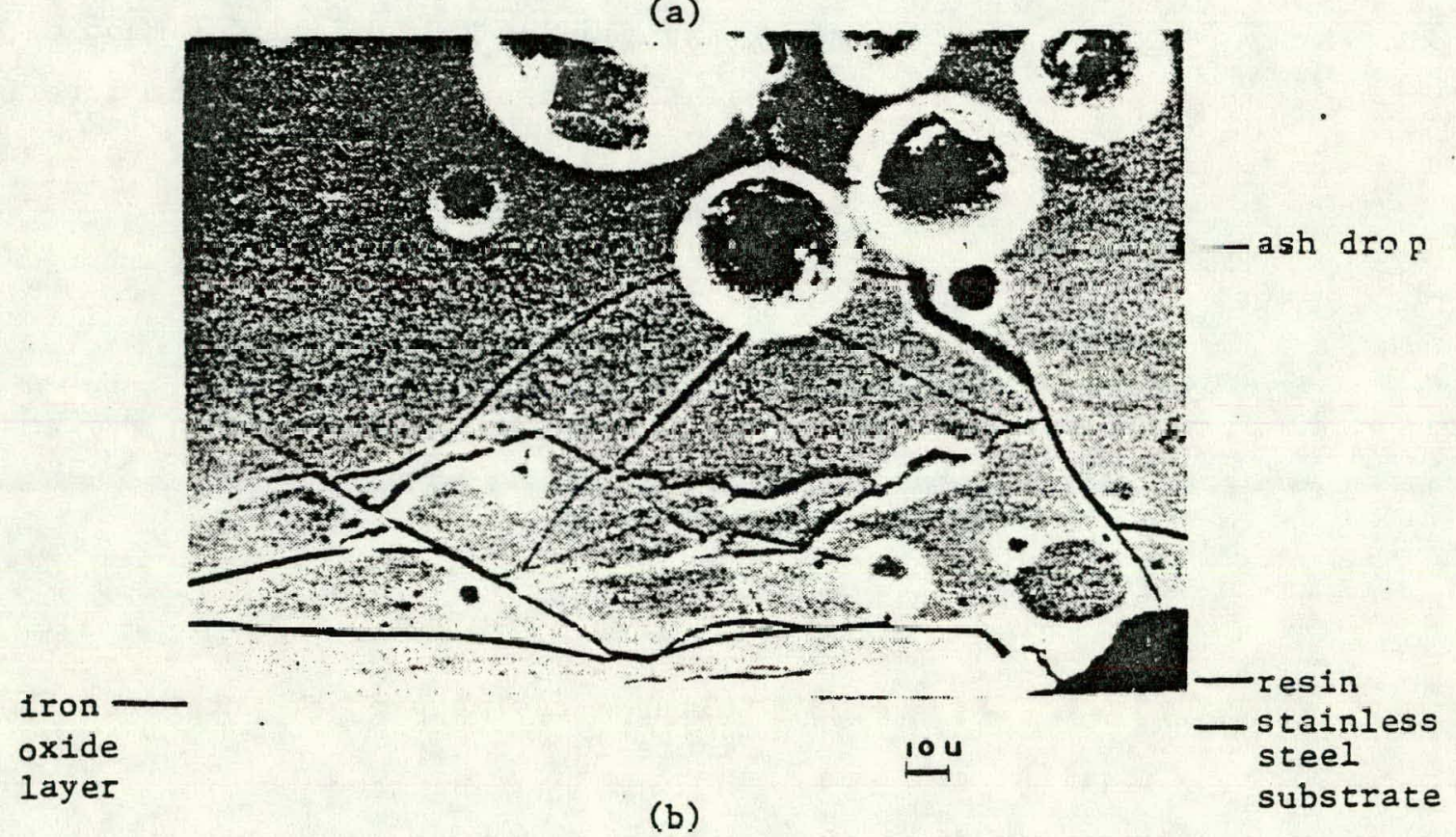

Figure 29. SEM photomicrographs showing cross-section characteristic of interface between Illinois \#6 LTA drop and oxidized 304 SS stainless steel substrate. Magnification of (b) fifteen times that of (a). 


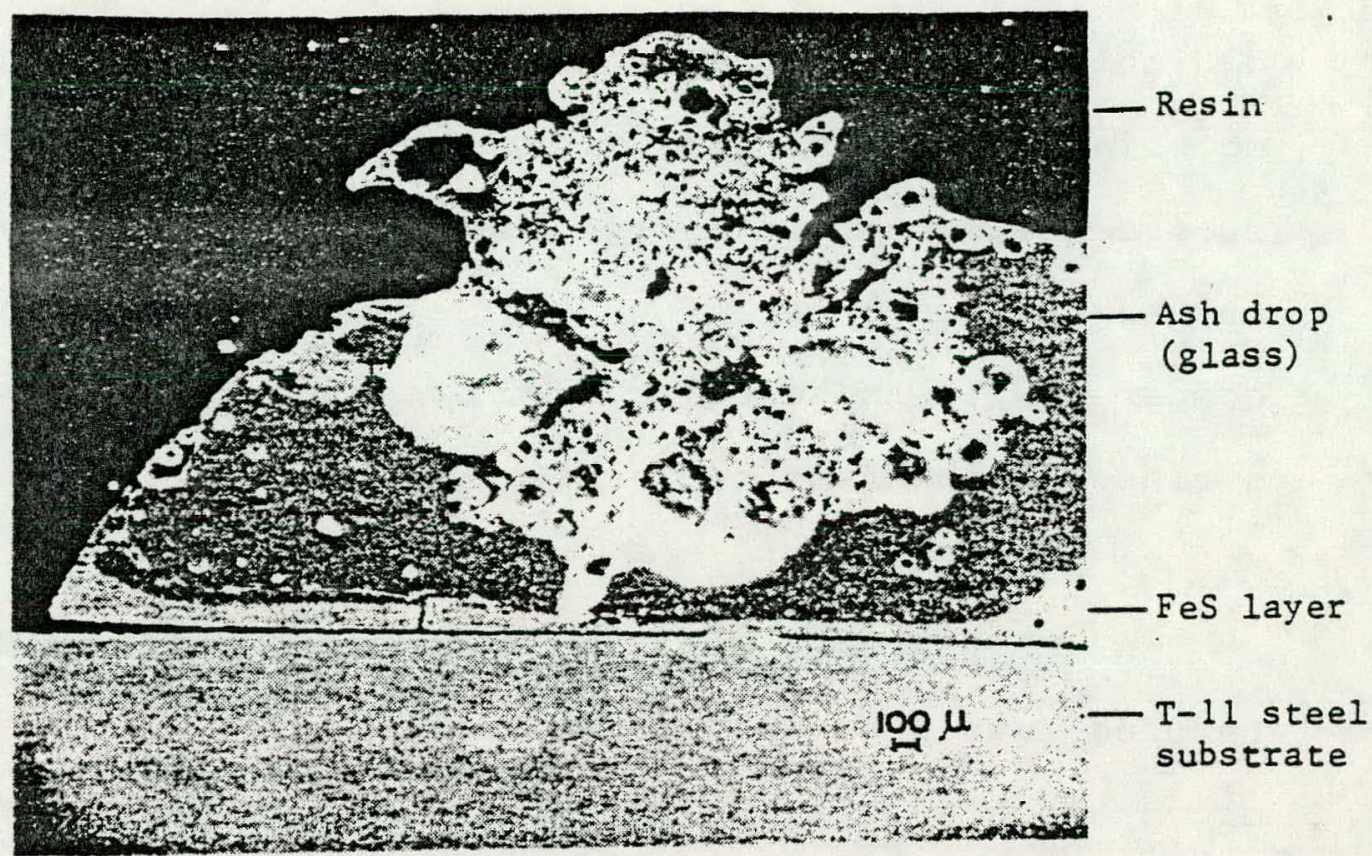

(a)

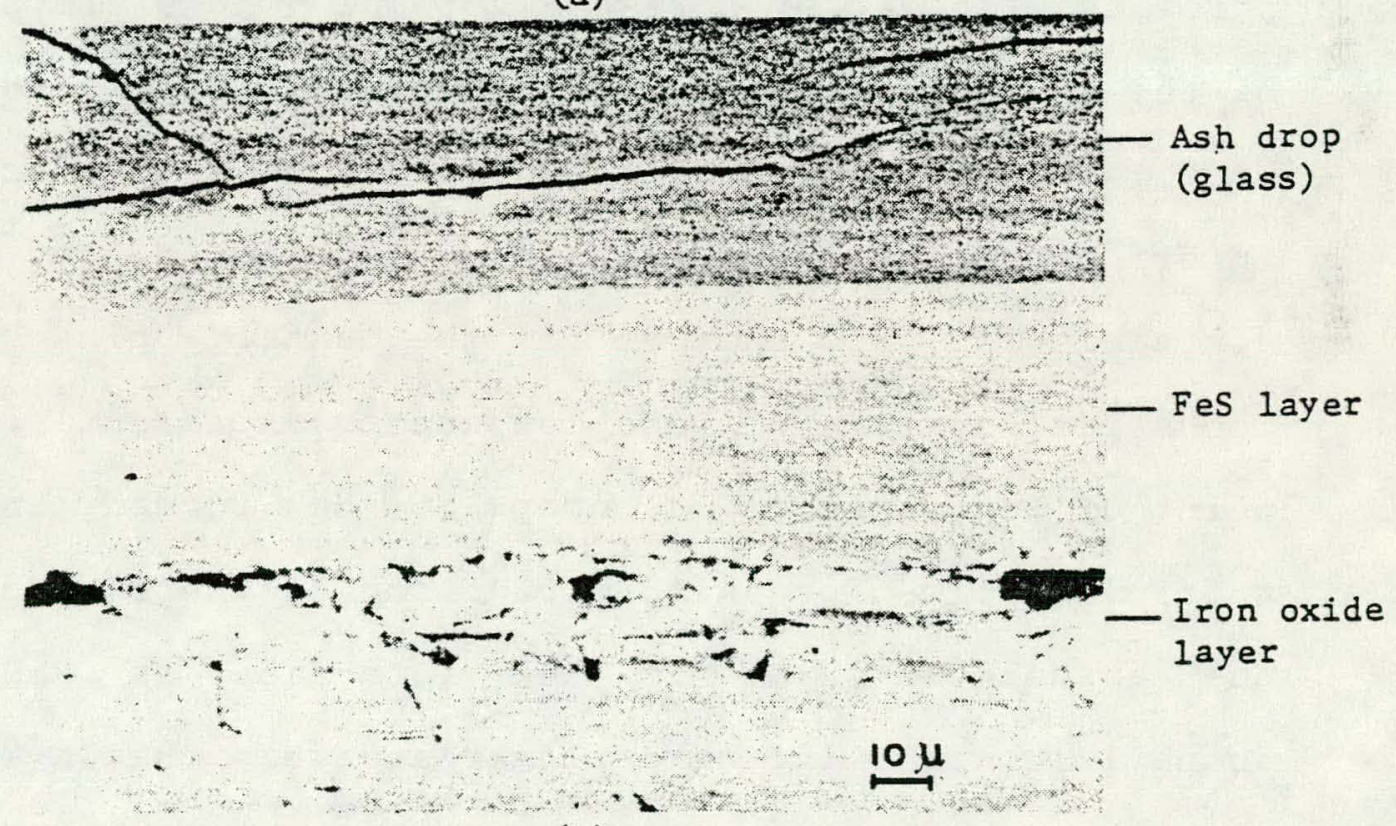

(b)

Figure 30. SEM photomicrographs showing cross-section characteristic of interface between $75 \%$ pyrite plus $25 \%$ kaolinite drop and oxidized T- 11 steel substrate. Magnification of (b) twenty times that of (a). 
The sticking behavior under reducing conditions was used to evaluate the nature of the adhesion of slag drops on the reduced T-11 surface. Drops from Illinois \#6 and Upper Hiawatha \#1 LTA did not adhere to the reduced surface, but drops from these materials gave strong adherence at $500^{\circ} \mathrm{C}$ on oxidized steel surfaces. Drops formed from the pyrite - kaolinite mixture gave an adhesion force of $95 \mathrm{~g}$ at $500^{\circ} \mathrm{C}$ on the reduced surface, compared with an adhesion force of $1000 \mathrm{~g}$ on the oxidized steel surface at the same temperature.

A comparison of SEM photomicrographs of the oxidized and reduced surfaces is given in Figure 31. Both surfaces are microporous, but the reduced surface appears to have a higher porosity with larger pores. Figure 32 shows SEM photomicrographs of the polished sections on the oxidized steel and on the reduced steel. The structure of the drop shows a surface layer at the interface which contains only $\mathrm{Fe}$ and $\mathrm{S}$ (by SEM-EDS); glass containing Al, Si, and Fe in the center; plus some regions of mechanical mixture of base components. Apparently the low melting point of Fes enables a drop to be formed and fall without sufficient time for uniform reaction of the base components. Thus the actual material at the interface is Fes. The FeS is compatible with the oxide layer and wets the layer, but there is no evidence for penetration into the pores to give mechanical anchoring. The contact between the drop and the reduced surface is much less compatible and there is again no evidence for mechanical anchoring in the microporosity. 


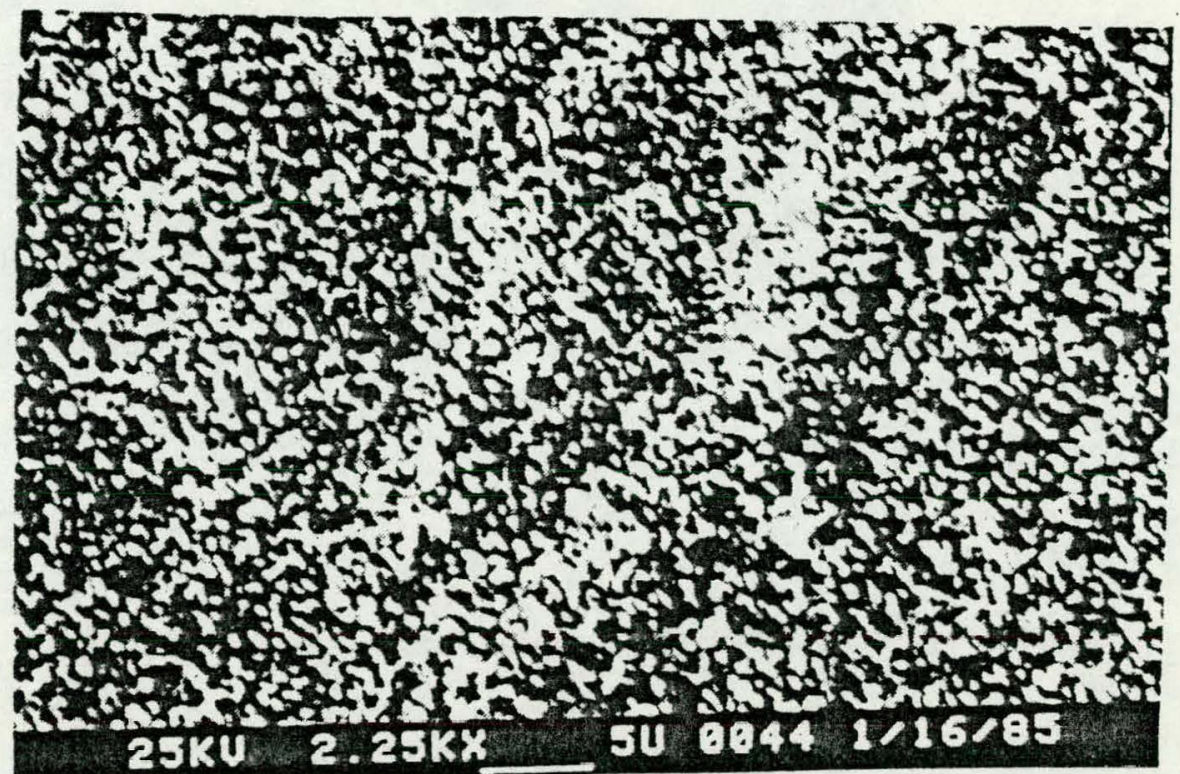

(a)

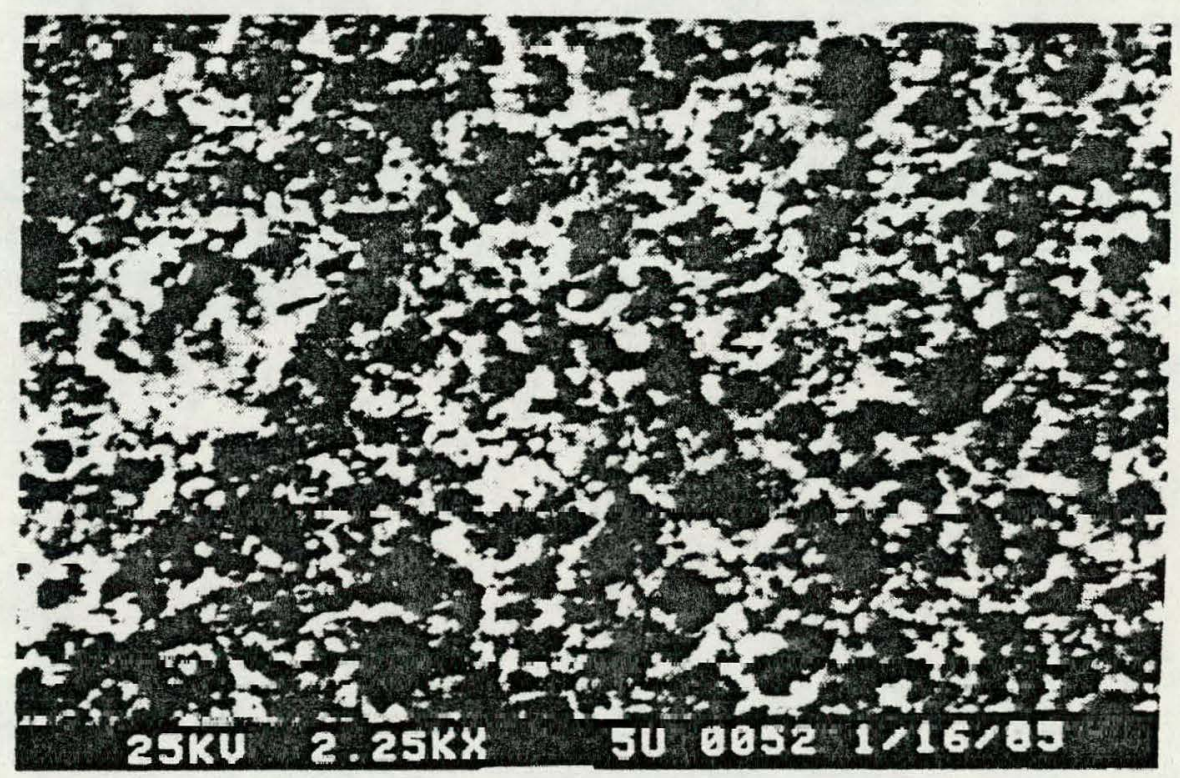

(b)

Figure 31. SEM photomicrographs of (a) the oxidized steel surface; and (b) the reduced steel surface. 


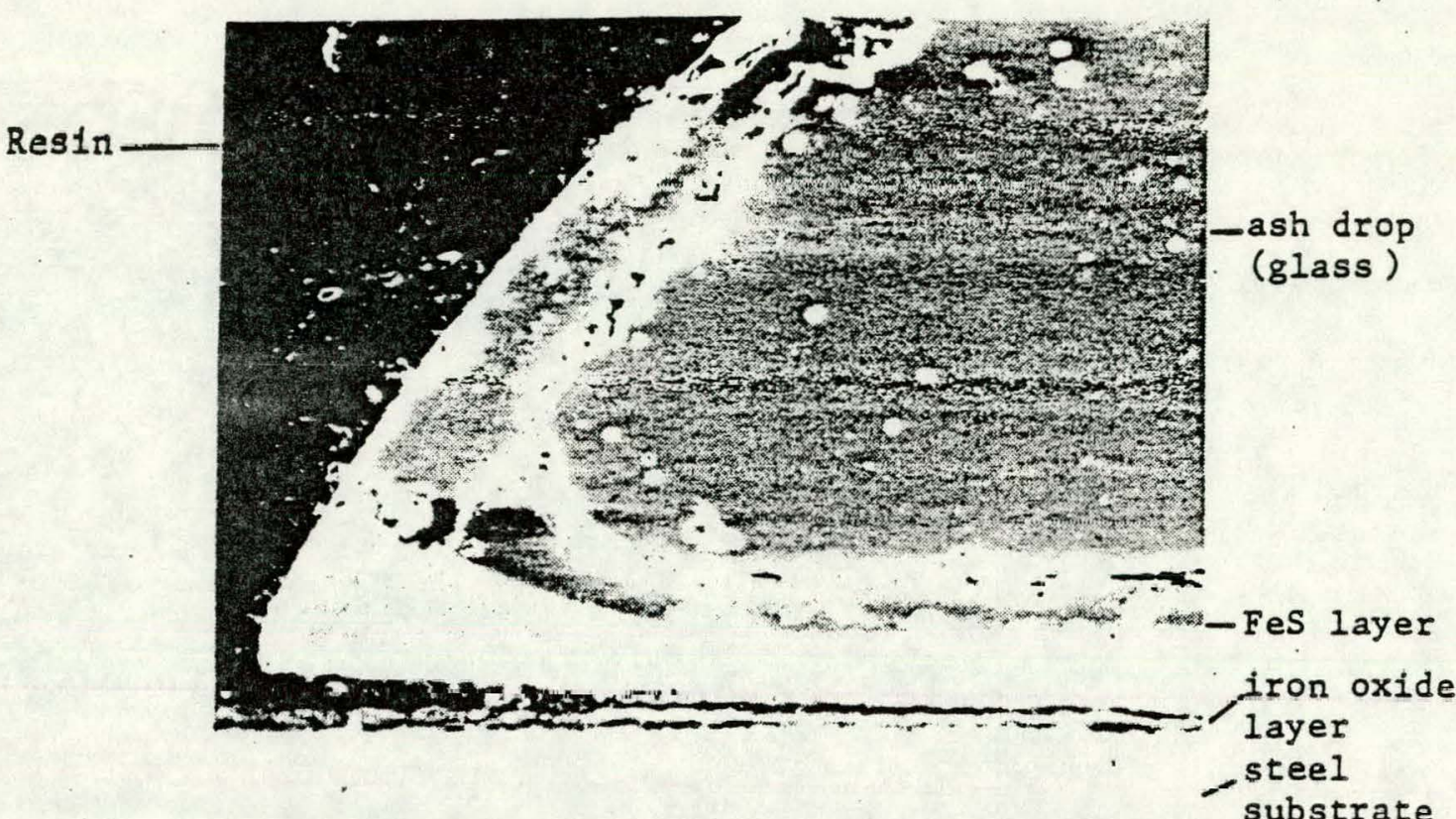

\section{KU 086X 100U $00391 / 164$}

(a)

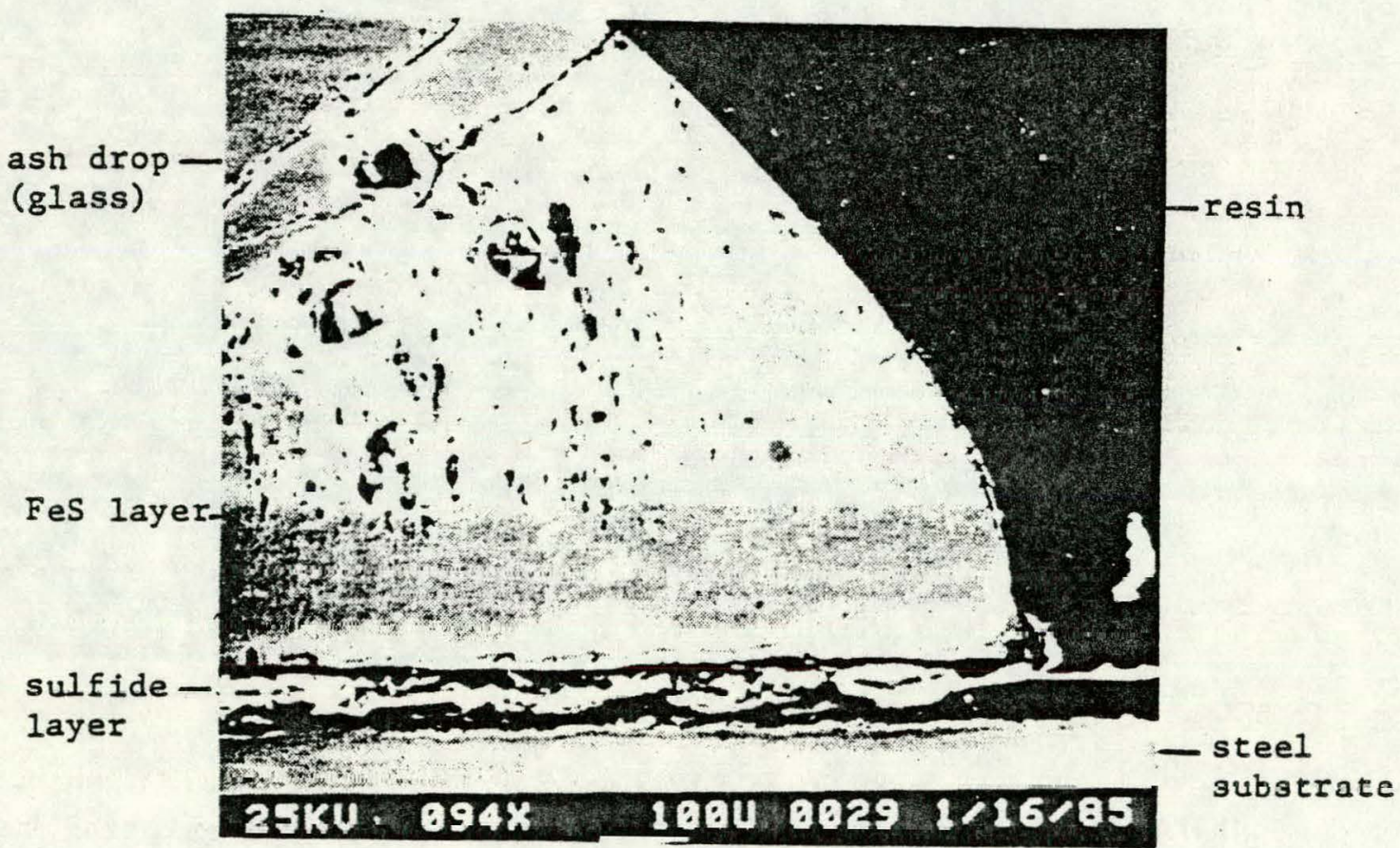

(b)

Figure 32. SEM photomicrographs of the polished cross-section of ash drop on (a) oxidized steel surface and (b) reduced steel surface. 
Figure 33 gives clear evidence of hemispherical particles spread on the oxide layer, forming the initiating layer. This photomicrograph is of a deposit produced from the Powder River Basin coal from Suite 1. The flattened particles were analyzed by SEM-EDS. The spectra showed significant amounts of $\mathrm{Na}, \mathrm{Mg}, \mathrm{Al}$, $\mathrm{Si}, \mathrm{S}, \mathrm{Ca}, \mathrm{Ti}$, and $\mathrm{Fe}$, with major peaks for $\mathrm{Ca}$ and $\mathrm{Fe}$. Analysis of the locations higher in the deposit gave major peaks for $\mathrm{Ca}$, $\mathrm{Al}, \mathrm{Si}$, and $\mathrm{Fe}$, but neither $\mathrm{Na}$ nor $\mathrm{S}$ were seen in the higher regions.

Application of the same techniques to the strongly adherent material of the high-rank coals showed that there were essentially four classes of particles with characteristic chemical compositions involved in the strongly adherent materials:

Type 1. Highly porous black particles with a rough surface texture were prominent. This type of particle contained mostly $\mathrm{Fe}$ with traces of $\mathrm{Al}$ and $\mathrm{Si}$.

Type 2. Glassy black spheres with smooth surface texture were also found. This type of particle contained $F e$ and smaller concentrations of $\mathrm{Al}, \mathrm{Si}, \mathrm{K}, \mathrm{Ca}$, and $\mathrm{Ti}$ with a trace of $\mathrm{s}$.

Type 3. Glassy transparent spheres with a smooth surface texture. This type of particle gave large EDS peaks for Ca and $\mathrm{Fe}$, with smaller peaks for $\mathrm{Al}$ and $\mathrm{Si}$.

Type 4. Black particles with a smooth surface texture 


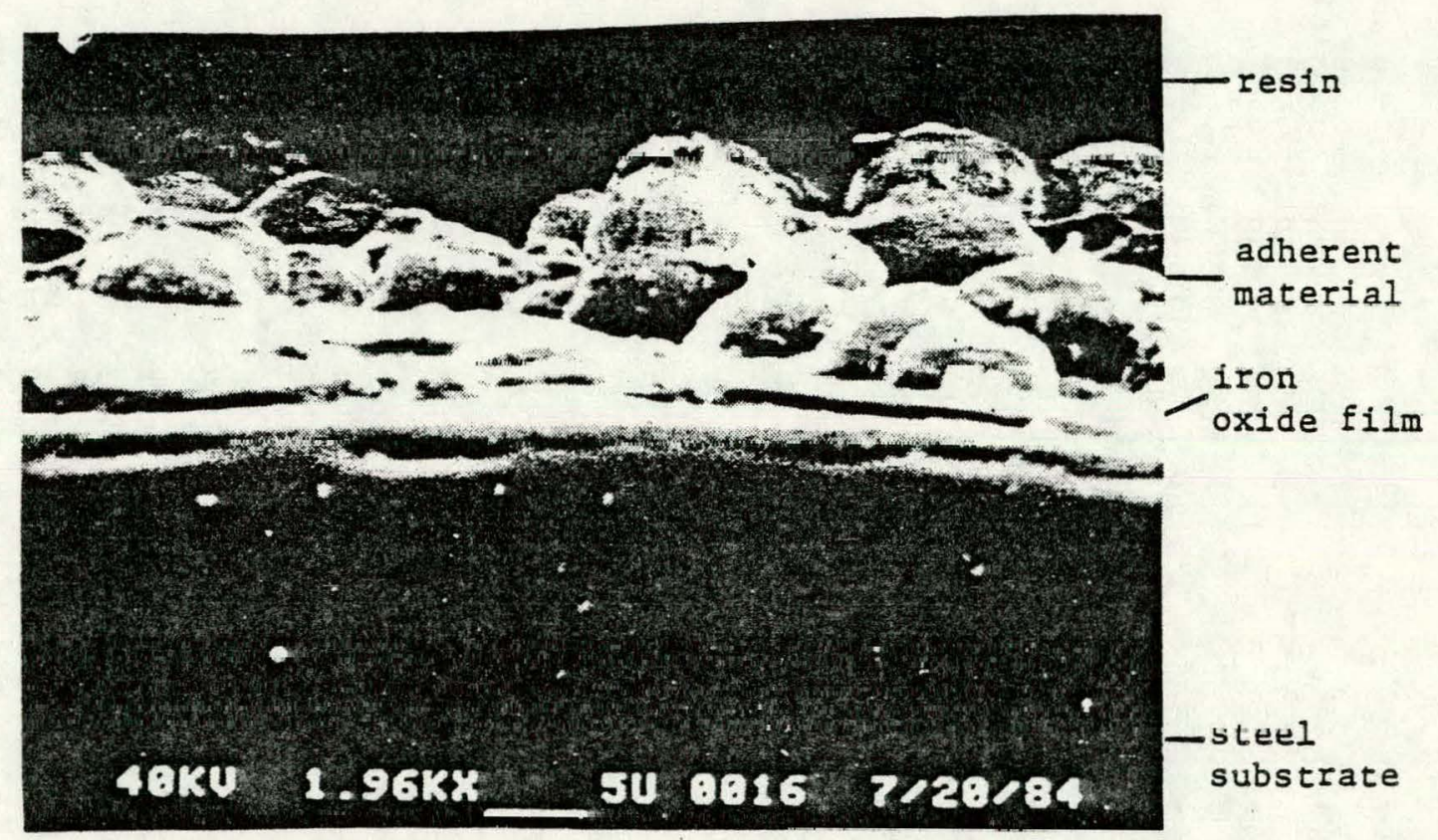

Figure 33. Strongly adherent particles forming an initiating deposit layer: deposit from Powder River Basin coal. 
containing $A I$ and $S i$ with a trace of $\mathrm{Fe}$.

- Types 1 and 2 made up most of the adherent layer from the high-rank coals, with a few Type 3 . Type 4 was found only in the adherent layer from the deposit produced from Pittsburgh \#8, along with the other types. The black particles of Type 1 were often deformed and flattened against the oxide film of the substrate, showing that the particles were molten on impact.

For the low-rank coals, Type 3 particles were predominant in the adherent material of the deposit. These high Ca and Fe content particles showed much less deformation, retaining more of the spherical shape even in contact with the oxide layer, indicating that these particles were sticky but had high viscosity upon deposition. These particles usually did not show significant concentrations of $\mathrm{Na}$ or $\mathrm{S}$.

A synthetic coal containing only illite formed a large deposit, probably due to the importance of a low melting point glass phase forming sticky particles, thus allowing for accumulation and growth of a massive deposit. (The sticking process is discussed in detail in the next section.) However, little material adhered after the deposit was brushed off the oxidized steel substrate, indicating that the glassy material from illite did not strongly adhere to the iron oxide layer on the substrate. Previous results from the sticking test using illite confirm this observation; the sticking temperature of the 
illite drop was relatively high $\left(450^{\circ} \mathrm{C}\right)$ and the adhesion. force at 500 - was very weak (about 2 grams).19 In contrast, the deposit from synthetic coals containing only pyrite or a mixture of pyrite and clay gave a significant amount of adherent material. This observation is also in agreement with previous results of the sticking test which showed a low sticking temperature of $250^{\circ}$ and a high adhesion force at $500^{\circ}$ of 100 grams.19 The adherent material was found to be rich in iron, suggesting that pyrite in coals leads to the formation of a strong initial deposit layer as well as a strong deposit mass.

The synthetic coals containing mixtures of pyrite and clays (illite and kaolinite) gave larger and stronger deposits than the deposit from the synthetic coal containing only pyrite. A high iron content but only a trace of glassy phase, probably formed from elays, were detected by $x$-ray diffraction analysic of these deposits. This observation suggests that most of the pyrite but not clays leads to formation of a deposit under these conditions. However, since the iron-rich fly ash contains a small amount of glass, this composition was therefore more likely to adhere and sinter, resulting in a significant deposit build-up.

The adhesive strength of small particles (i.e., about 100 micrometers in diameter) was measured by an attachment for the deposit strength apparatus. The design, and construction of the strength apparatus is given in detail in the section on development of deposit strength. For measuring adhesive strengths 
of small particles the apparatus is attached to the stage of an optical microscope. A needle of small blade is attached to the end of the rod, which is then used as a ram to shear off the particle at room temperature. The pressure exerted to shear the particle is measured; results are reported based on the total area of contact to the oxide layer. This apparatus was used to study adherent particles produced in combustion of the suite 2 coals. SEM-EDS analyses of the adherent particles were performed prior to measurements of the adhesive strengths of the same particles.

Adherent particles from Center lignite mostly contained significant quantities of calcium and sulfur, probably as calcium sulfate. These particles have adhesive strengths of 3.0 - 3.7 MPa. The particle having the highest adhesive strength contains high concentrations of iron and silicon, possibly as fayalite $\left(\mathrm{Fe}_{2} \mathrm{SiO}\right.$ ) which has a low melting point of $1200^{\circ} \mathrm{C}$. The quantity of adherent particles was greatly reduced when testing Center lignite from which the cations had been removed by ion exchange. The ion-exchange procedure removed calcium present as carboxylate salts or as soluble sulfates (i.e., gypsum). The substrate from the test with ion-exchanged lignite produced proportionately more adherent particles rich in iron but fewer total adherent particles.

Most of the adherent particles in deposits from San Miguel lignite which showed high adhesive strengths contained high 
concentrations of iron and silicon.: Similar particles were present in deposits produced from Martin Lake lignite.

The comparison of adherent particles produced from Rosebud subbituminous coal with those from the 1.4 specific gravity float and $1.6 \mathrm{s.g}$. sink fractions of the same coal enabled the isolation of adherent particles specific to each gravity fraction. The $1.4 \mathrm{~s} . \mathrm{g}$. float fraction produced a very small quantity of adherent particles. The particles are about 18 to 25 micrometers in diameter. Some have high concentrations of calcium and phosphorus, possibly as a calcium phosphate. (However, no significant enrichment of phosphorus is noted in the ash analysis of the 1.4 s.g. float.) Magnesium is also abundant in the adherent particles from the $1.4 \mathrm{~s} . \mathrm{g}$. float. Unfortunately the particles were too small to obtain adhesive strength measurements. A test with the $1.6 \mathrm{~s} . \mathrm{g}$. sink fraction produced numerous large adherent particles, many of which contain signifioant quantities of sulfui and irvin. The piesenee of sulfui is due to insufficient residence time in the hot zone to facilitate complete decomposition and oxidation of pyrite in the coal to iron oxides. The adhesive strengths of the iron sulfide particles range from $2.2-4.6 \mathrm{MPa}$. A particle containing mostly iron and gilieon had the highest adhesive strength, $7.1 \mathrm{MFa}$.

For all the coals examined, the ash particles that have the highest adhesive strengths appear to be those rich in iron and silicon. Strengths ranged from $7.1-76 \mathrm{MPa}$. The next group of 
particles that exhibit a measurable strength of adhesion contain iron and sulfur and have adhesive strengths ranging from 2.24.6 MPa. The final group of particles that have measurable strength of adhesion are those rich in calcium and sulfur, having strengths of $3.0-3.7 \mathrm{MPa}$. Other types of adherent particles were also identified but no data on adhesive strengths was obtained; these particles include ones rich in barium and sulfur; in bàrium, strontium, and sulfur; in calcium and phosphorus; and in iron.

To place these strength measurements into some context, the strength of adhesion of epoxy resin on steel can be as high as 40 $\mathrm{MPa}$ and that of enamel coatings on metals can exceed $50 \mathrm{MPa} .21$ It has been estimated that an adhesive bond of $0.1 \mathrm{kPa}$ is able to support the weight of a $10 \mathrm{~mm}$ thick lightly sintered ash deposit having a density of $1000 \mathrm{~kg} / \mathrm{m}^{3} .14$

Build-up of the Deposit: The Sticking Process

Table 42 gives the deposit rates for the suite 1 coals when $10 \mathrm{~g}$ of each coal was fed to the furnace over a period of 30 minutes. Figure 34 shows the variation of deposit mass with time. As the deposit grows, the rate of deposition increases, since the top of the growing deposit will become increasingly hotter. Figures 35 and 36 show the deposition rates estimated by differentiation of the curves in Figure 34 , normalized by dividing the rate of firing of high temperature ASTM ash in the 
Table 42. Deposit wass and percent ash recovered as deposit for test coals: total coal feed $=10 \mathrm{~g}$; feed time $=30 \mathrm{~min}$.

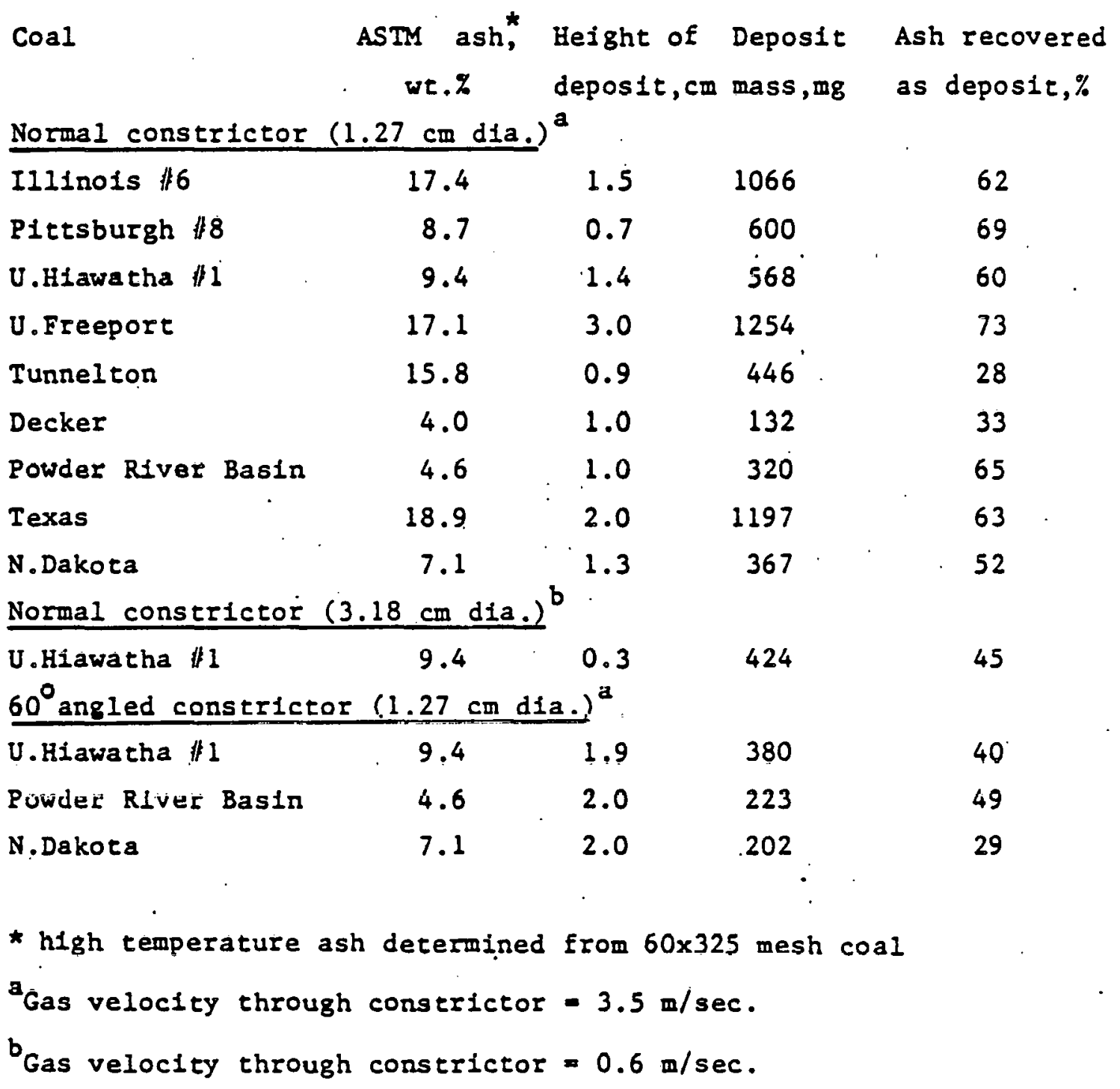




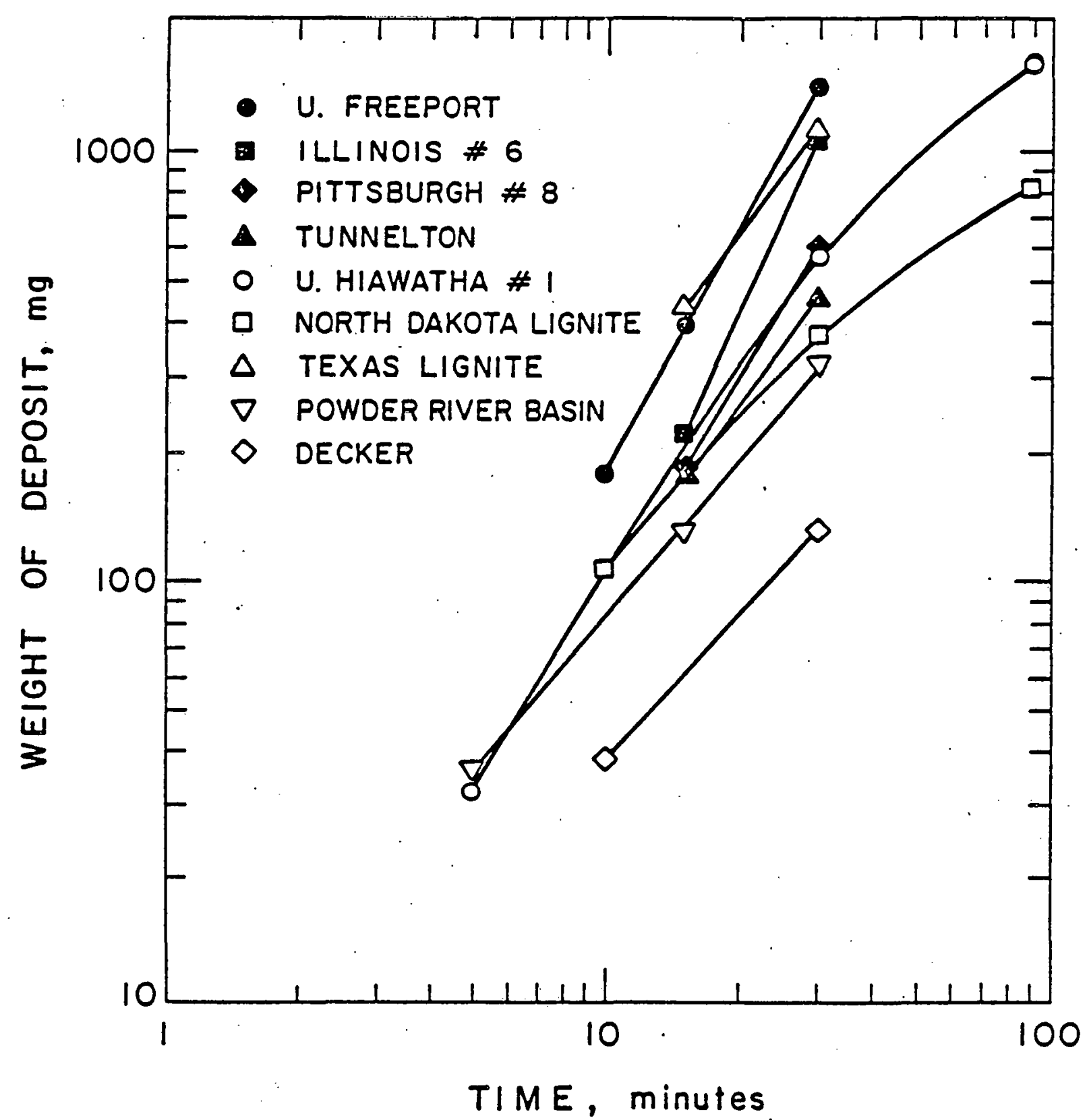

Figure 34. Weight of deposit versus time: $\operatorname{coal}$ feed rate $=1 / 3 \mathrm{~g} / \mathrm{min}$.; excess air $=20 \%$; furnace temperature $=1500^{\circ} \mathrm{C}$; substrate temperature $=500^{\circ} \mathrm{C}$; gas temperature at the location $2 \mathrm{~cm}$ above the substrate $=1300^{\circ} \mathrm{C}$; gas velocity through the normal constrictor $=3 \mathrm{~m} / \mathrm{sec}$. 


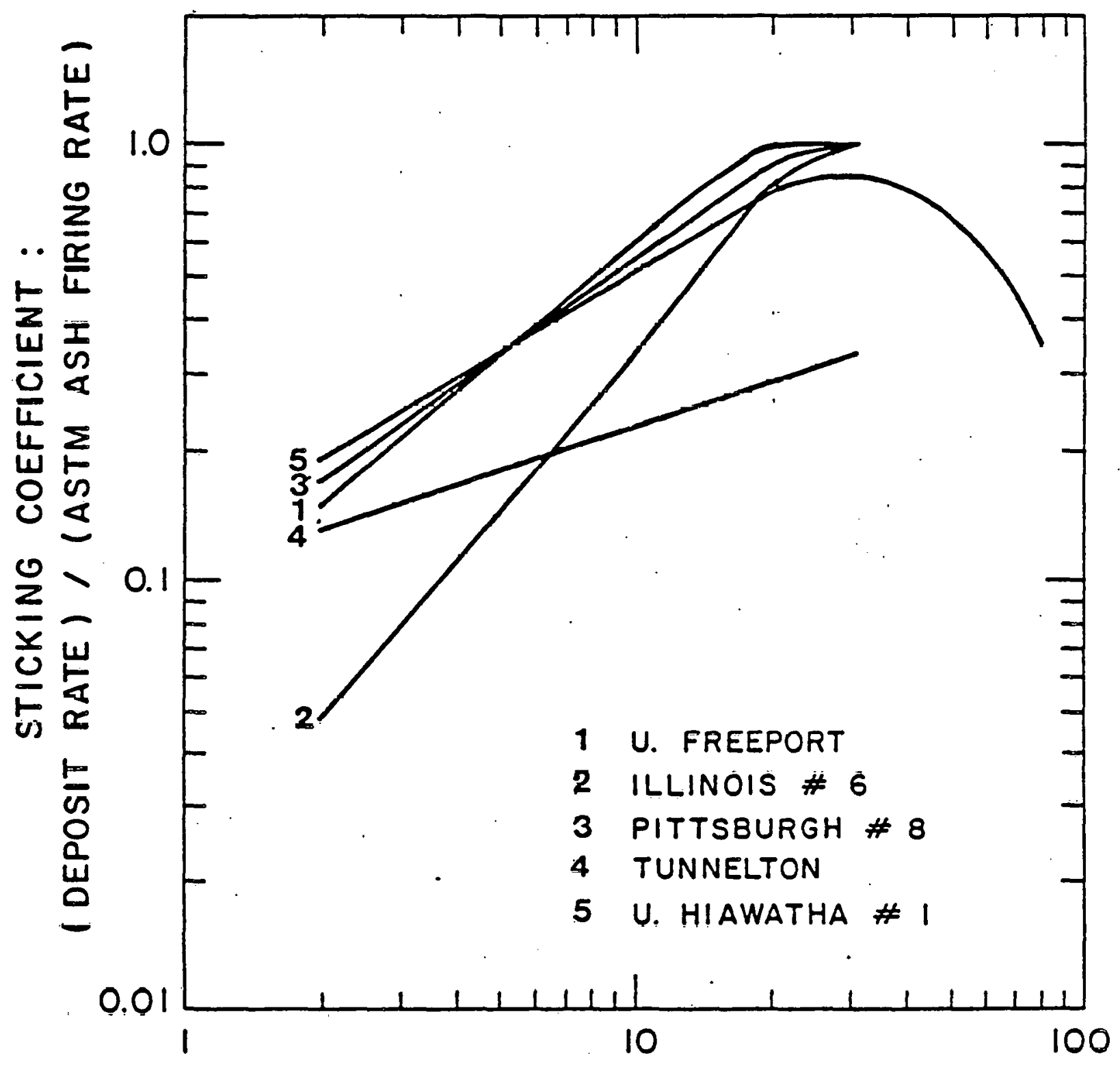

TIME, minutes

Figure 35. Deposit rate as a fraction of ash (ASTM) firing rate, versus deposition time: high-rank coals; coal feed rate $=1 / 3 \mathrm{~g} /$ minutc; excess air $=20 \%$; furnace wall temperature $=1500^{\circ} \mathrm{C}$; substrate temperature $=500^{\circ} \mathrm{C}$; gas temperature at the location $2 \mathrm{~cm}$ above the substrate $=1300^{\circ} \mathrm{C}$; gas velocity through the constrictor $=3 \mathrm{~m} / \mathrm{sec}$. 


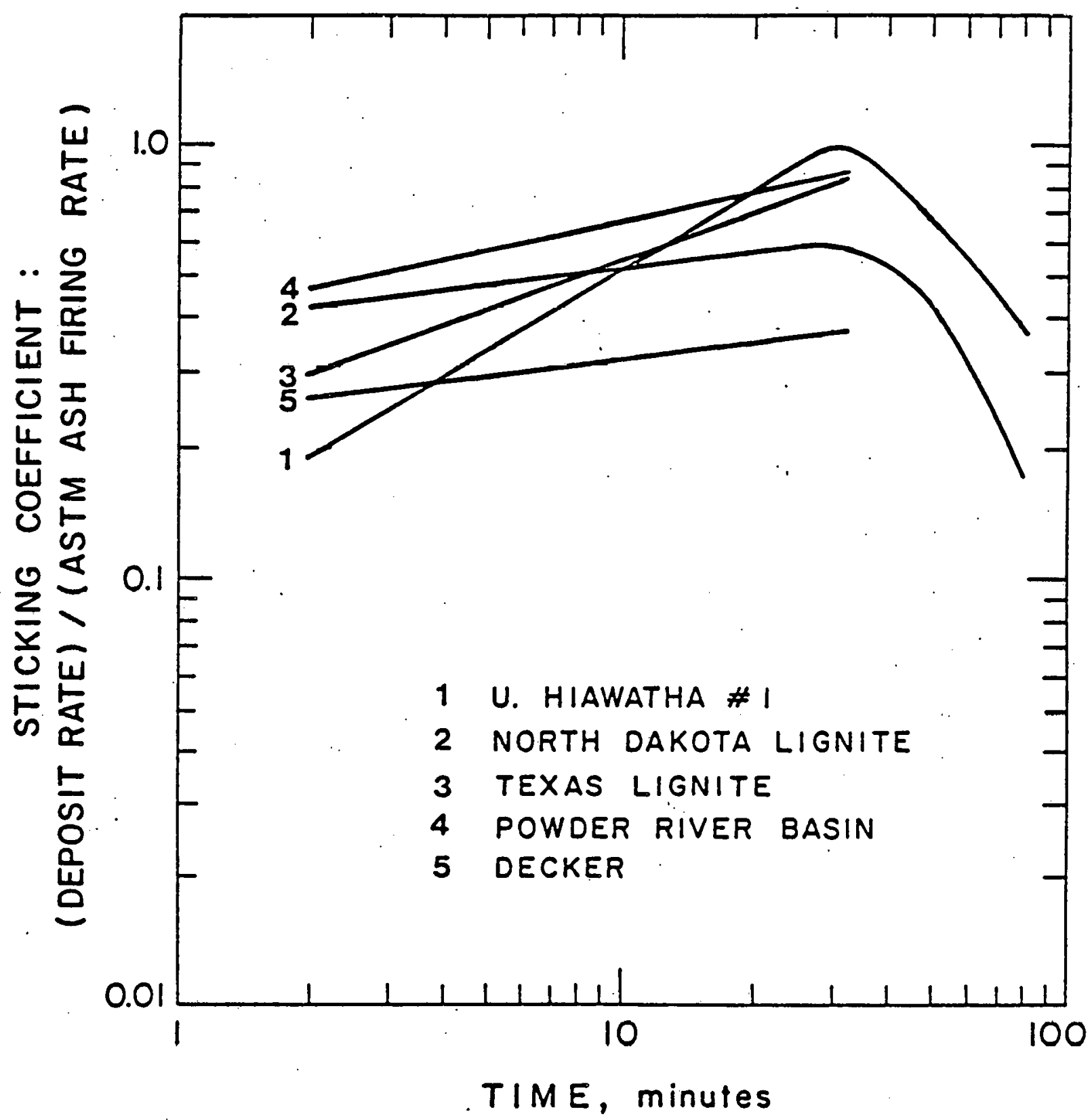

Figure 36. Deposit rate as a fraction of ash (ASTM) firing rate, versus deposition time: low-rank coals; coal feed rate $=1 / 3 \mathrm{~g} /$ minute; excess air $=20 \%$; furnace wall temperature $=1500^{\circ} \mathrm{C}$; substrate temperature $=500^{\circ} \mathrm{C}$; gas temperature at the location $2 \mathrm{~cm}$ above the substrate $=1300^{\circ} \mathrm{C}$; gas velocity. through the constrictor $=3 \mathrm{~m} / \mathrm{sec}$. 
$0.33 \mathrm{~g} / \mathrm{min}$ of coal. These Figures emphasize the differences in the way the deposit grows. For example, Illinois \#6 shows a strongly accelerated rate of growth, whereas Tunnelton and the low-rank coals show a more uniform rate of deposition. Most of the bituminous coals, except Tunnelton, reached a sticking coefficient close to 1 at the end of the deposition time of 30 minutes, showing that when the deposit reaches a certain height, the top of the deposit can give virtually complete capture of the fly ash. (The sticking coefficient, also called. the sticking fraction, is defined as the actual deposit weight divided by the quantity of ash fed based on the ASTM ash determination.) However, at longer deposition times (up to 90 minutes), the sticking coefficient decreases, probably because the changing of the deposit shape as the deposit grows alters the flow of gas around the deposit. Consequently, there appears to be a fraction of fly ash entering the nozzle that simpiy by-passes the deposit. The behavior of Upper Freeport and Tunnelton is remarkable in that the coals have almost identical ash compositions: yet give entirely different deposition behavior.

The gas - particle stream was accelerated as it passed through the constrictor. The deposit formed on the substrate at the point where the gas - partiole stream underwent a sharp change in direction. Most of the molten or sticky particles could stick nearer to the center of the substrate, whereas less sticky particles move on with the gas stream. The deposit forming at the center of the substrate had, therefore, the typical appearance of 
a cone that grows in the direction of the incoming hot gases, as illustrated in Figure 37. It was quite easy to see the direction of gas flow indexed by the growth lines in the deposit. This provides evidence that the mechanism of growth is direct head-on impingement, while particles skimming a surface may not stick to it.

For the coals in Suite 2, the North Dakota lignites showed a gradually increasing to even growth rate, as shown in Figures 38 and 39. The Indian Head and Beulah lignites showed a more even rate of growth compared to the Center and Velva lignites. This difference may be due to the higher concentrations of sodium in the Indian Head and Beulah lignites, the sodium being likely to form very small particles which would follow the gas streamlines and not be deposited.

The Gascoyne lignite samples were from different pits within the same mine. The plots of deposit weights as a function of time are given in Figures 40 and 41 . The White and Yellow pit samples have higher sticking fractions than the Blue and Red samples. The White pit sample showed an accelerated growth rate. The moiphology of the deposit produced from this sample was indicative of abundant liquid having been present at the top of the deposit; the liquid would create a captive surface which would retain most particles striking it.

The subbituminous corls in Suite 2 generally showed a 


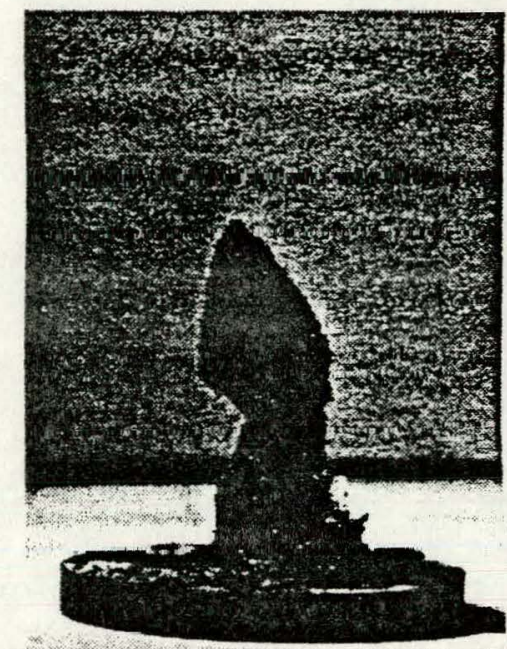

(a)
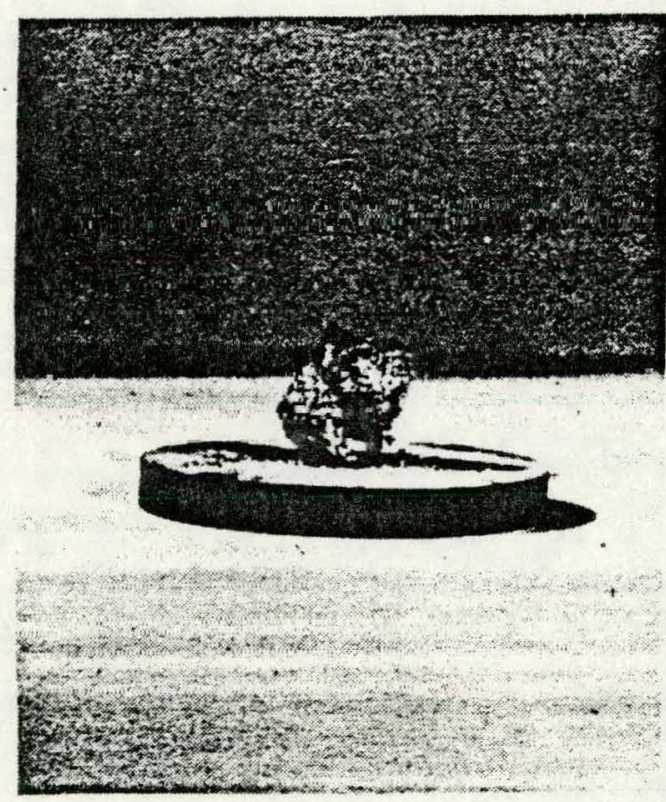

(d)

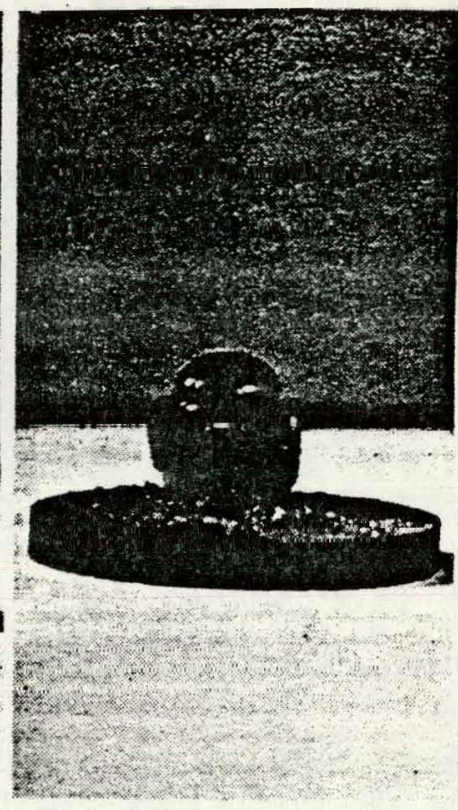

(b)

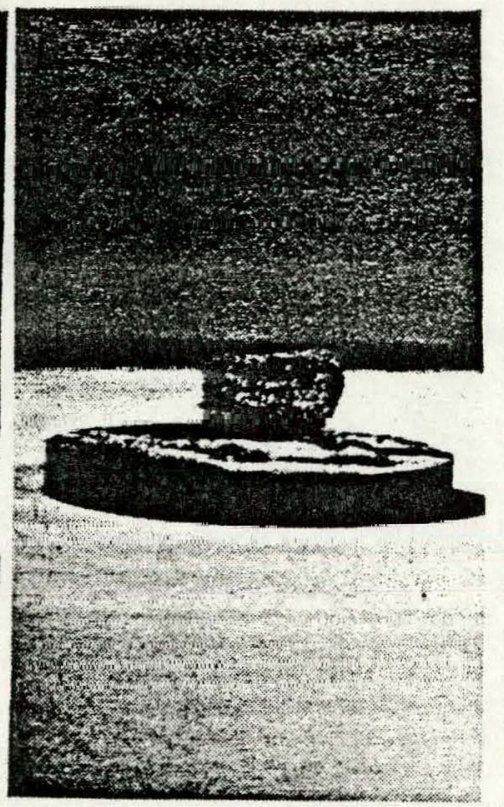

(c)

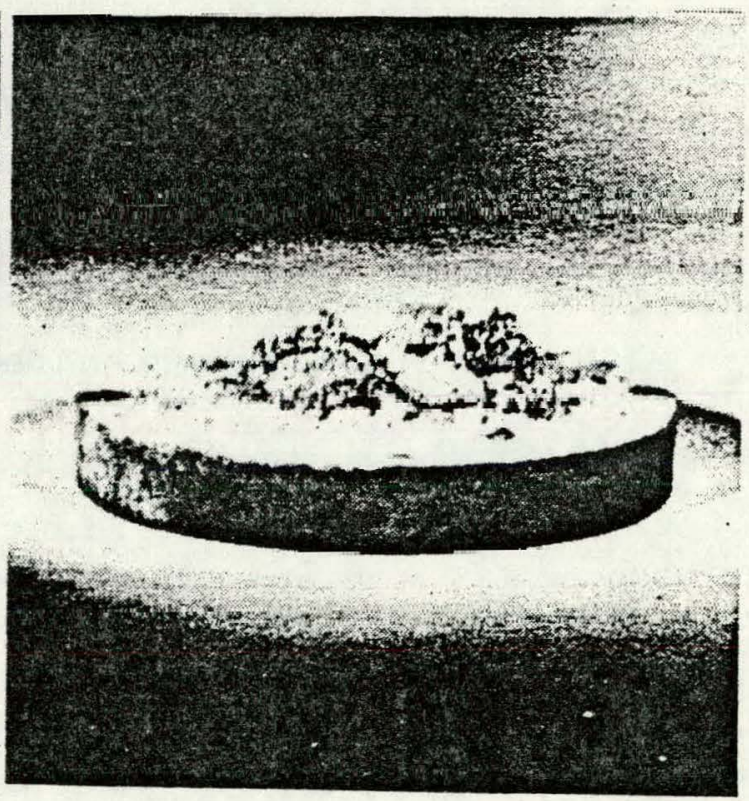

(e)

Figure 37. Appearance of deposit for (a) Upper Freeport; (b) Illinois \#6; (c) Pittsburgh \#8; (d) Upper Hiawatha \#1; and (e) Tunnelton. 


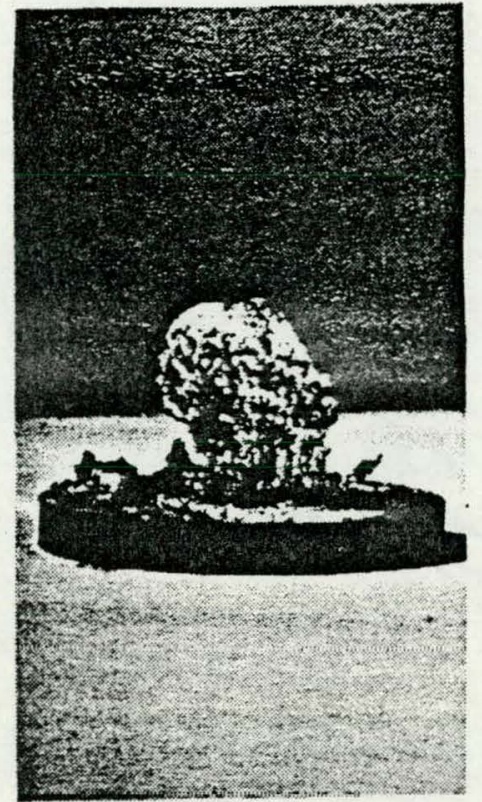

(a)

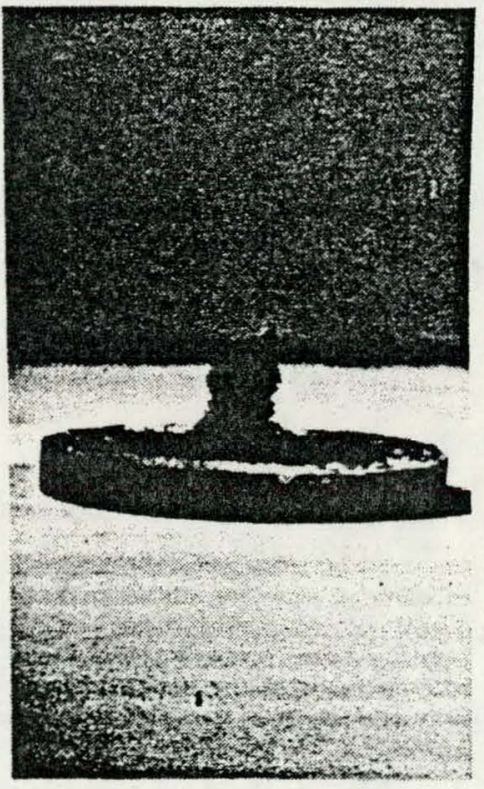

(c)

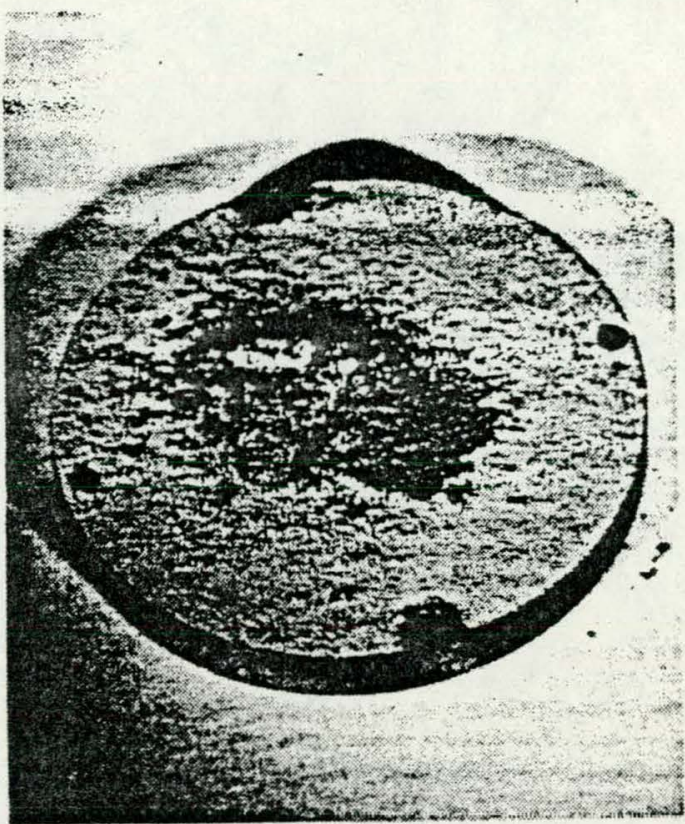

(b)

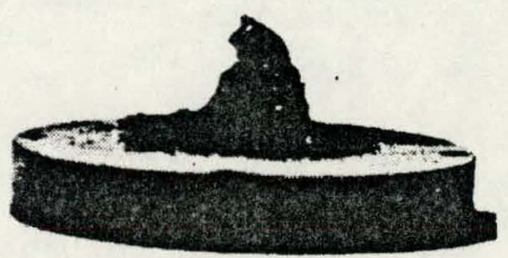

(d)

Figure 37. Appearance of deposit for (a) Texas; (b) Decker; (c) North Dakota; and (d) Powder River Basin. 


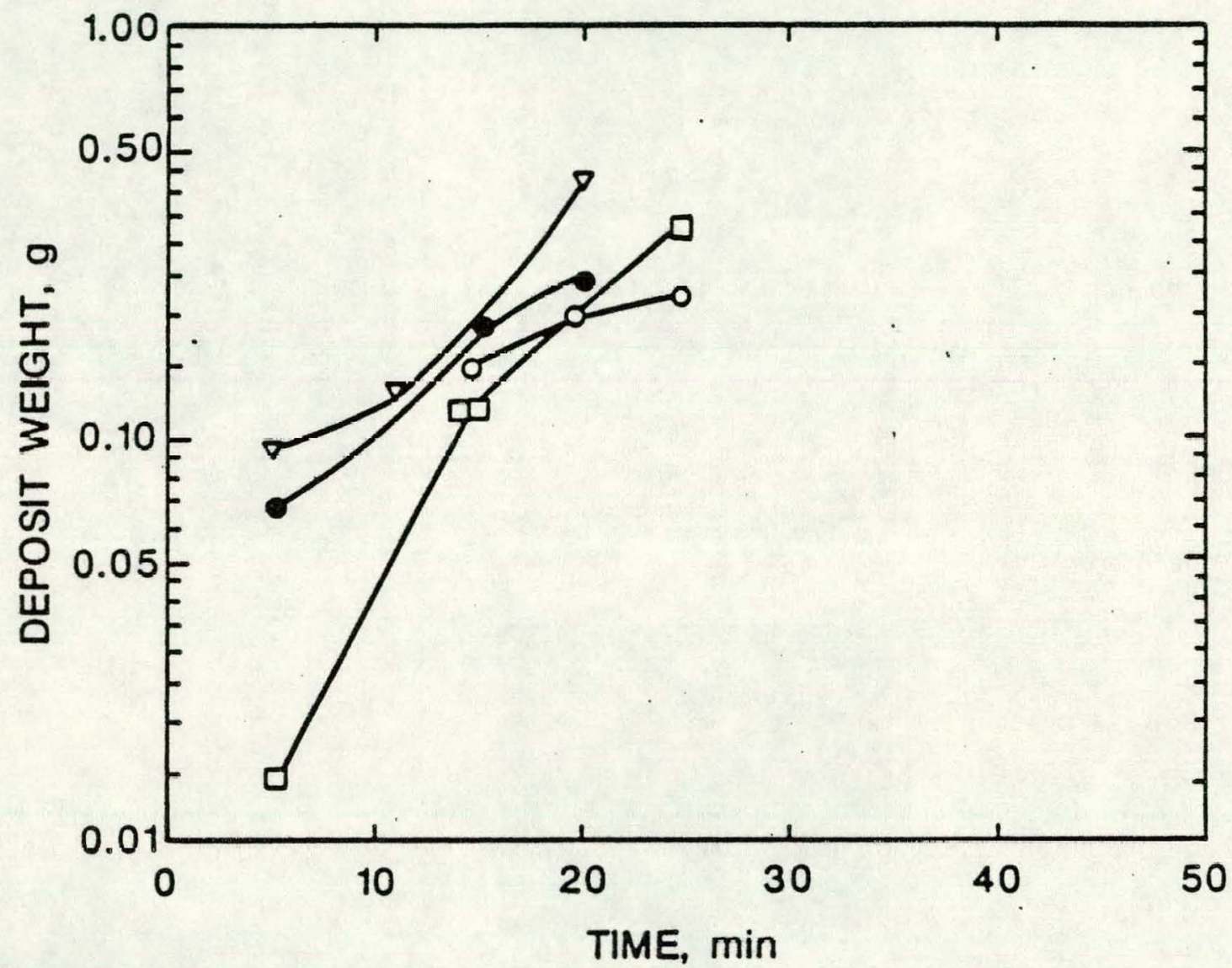

Figure 38. Deposit weight versus time for selected North Dakota lignites from different mines: coal feed rate $0.2-0.4 \mathrm{~g} / \mathrm{min} ; 20 \%$ excess air; hot zone temperature $=1500^{\circ} \mathrm{C}$; gas temperature at constrictor $\sim 1260^{\circ} \mathrm{C}$; gas velocity across substrate $3-4 \mathrm{~m} / \mathrm{sec}$.

( $O$ - Beulah; - Velva, $\square$ - Indian Head, and $\nabla$-Center.) 


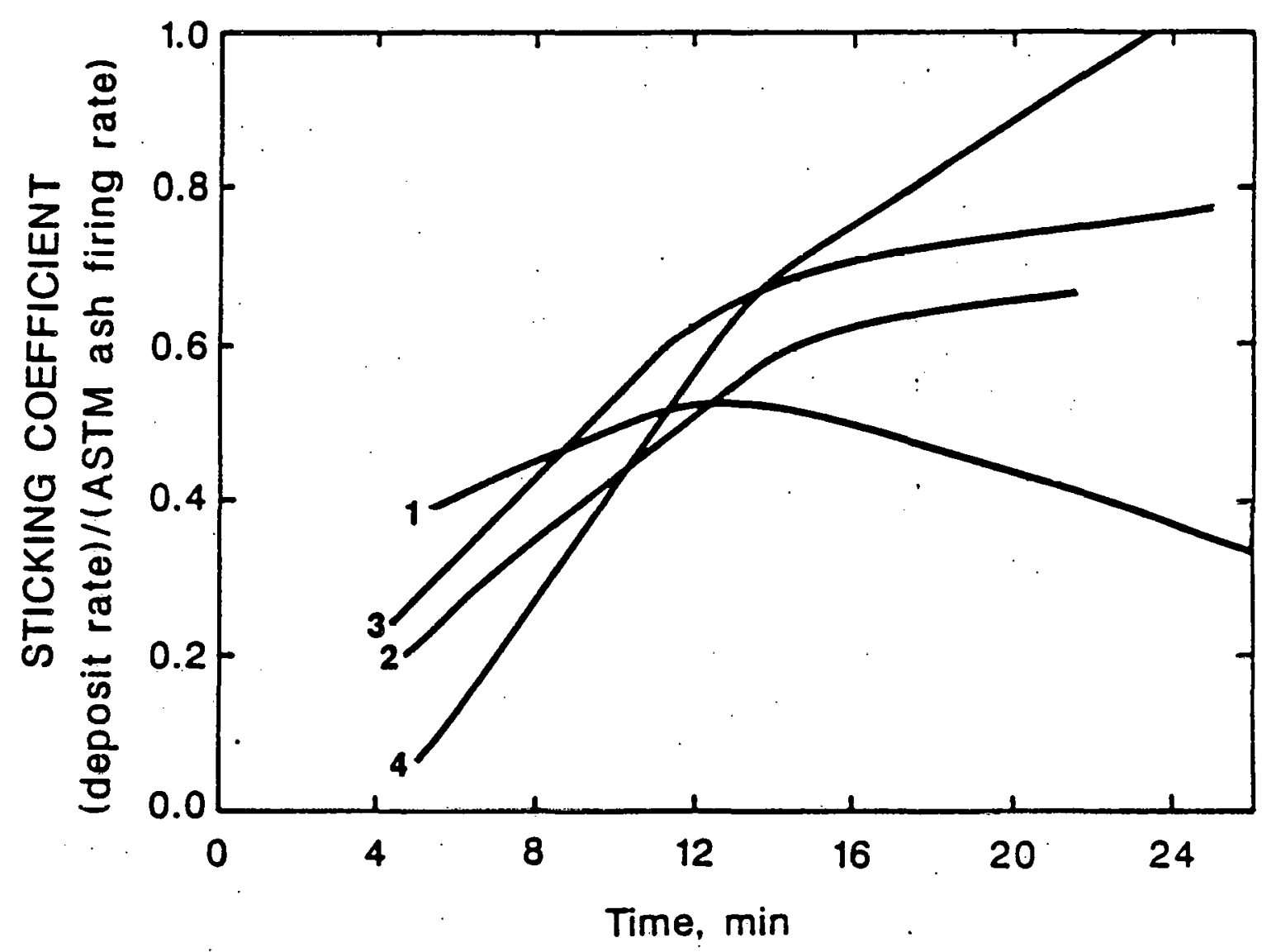

Figure 39. Sticking coefficient versus time for selected North Dakota lignites from different mines: coal feed rate $0.2-0.4 \mathrm{~g} / \mathrm{min} ; 20 \%$ excess air; hot zone temperature $=1500^{\circ} \mathrm{C}$; gas temperature at constrictor $-1260^{\circ} \mathrm{C}$; gas velocity across substrate $3-4 \mathrm{~m} / \mathrm{sec}$. (1-Beulah, 2-Velva, 3- Indian Head and 4-Center) 


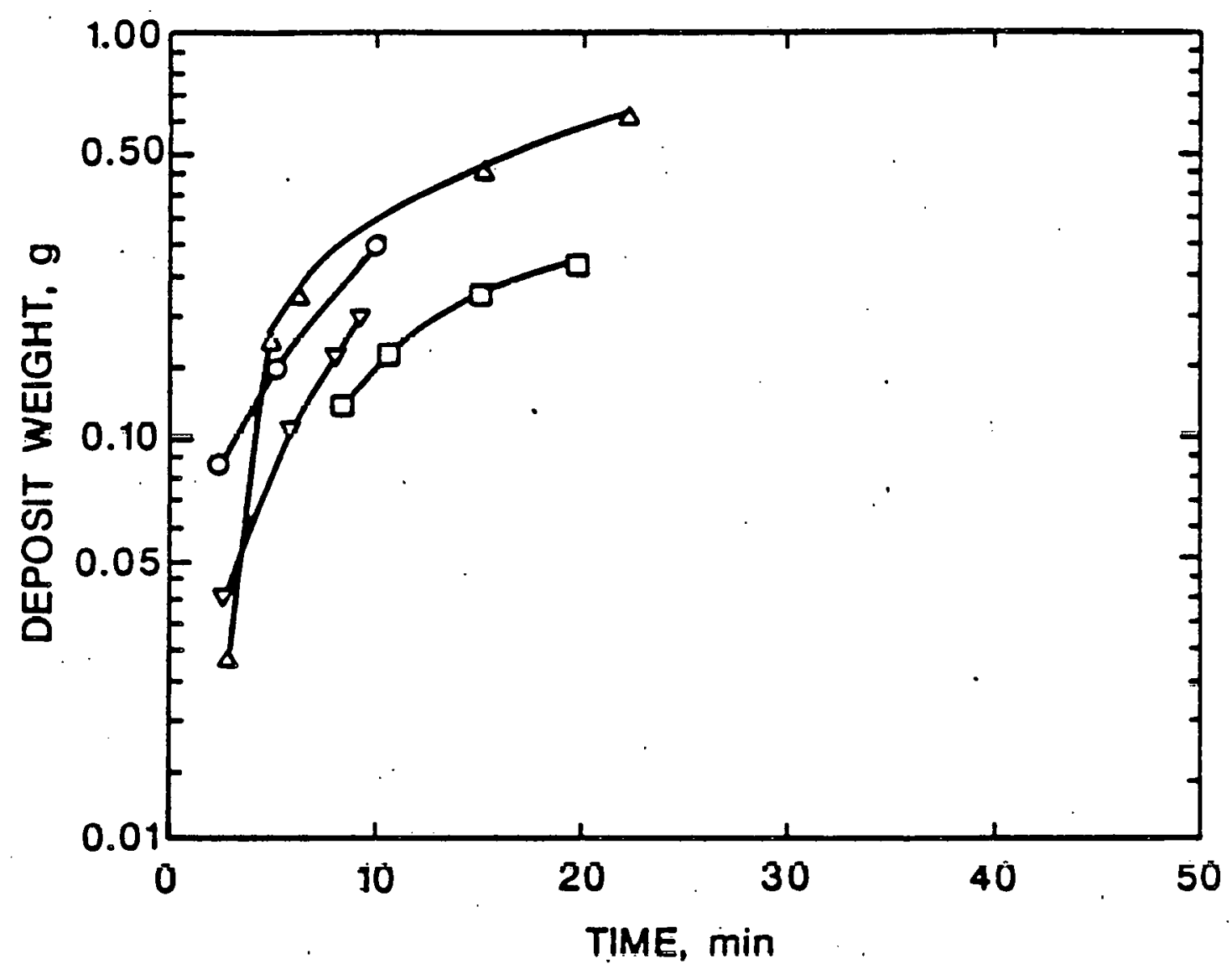

Figure 40. Deposit weight versus time for Gascoyne North Dakota lignites from different pits: coal feed rate $0.2-0.4 \mathrm{~g} / \mathrm{min}$; $20 \%$ excess air; hot zone temperature $=1500^{\circ} \mathrm{C} ;$ gas temperature at conser1ctor $\sim 1260^{\circ} \mathrm{C} ;$ gas velocity across the substrate $3-4 \mathrm{~m} / \mathrm{sec}$.

( $\nabla$ - Gascoyne Red, $\Delta-$ Gascoyne White, $\square-$ Gascoyne Blue and $O$ - Gascoyne Yellü.) 


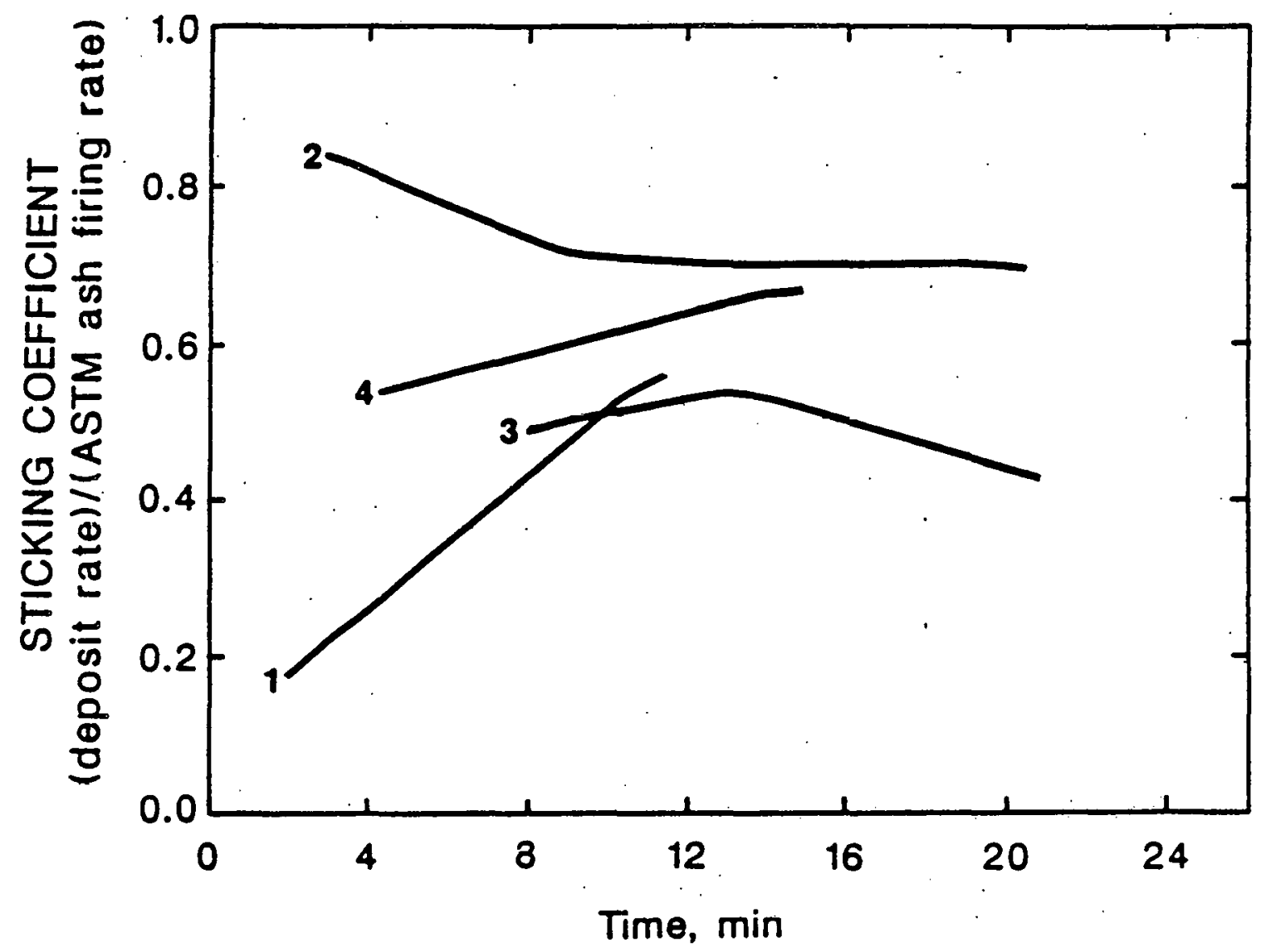

Figure 41. Sticking coefficient versus time for Gascoyne North Dakota lignites from different pits: coal feed rate $0.2-0.4 \mathrm{~g} / \mathrm{min} ; 20 \%$ excess air; hot zone temperature $=1.500^{\circ} \mathrm{C} ;$ gas temperature at constrictor $-1260^{\circ} \mathrm{C}$; gas velocity across substrate $3-4 \mathrm{~m} / \mathrm{sec}$.

( 1-Gascoyne Red, 2 - Gascoyne White, 3 - Gascoyne Blue, and 4-Gascoyne Yellow.) 
behavior similar to that of the North Dakota lignites..However, the sticking fraction shows a gradual increase at the initial stages of deposit formation and then appears to drop slightly (Figure 42). Two factors may account for this behavior of the sticking fraction; First, changes in the flow patterns of the gas -stream, caused by deposit growth, may decrease the possibility of fly ash impaction. Second, these deposits did not appear to have been fused at the top, so there may have been no significant quantity of molten material present to produce a captive surface.

The sticking fraction as a function of time is plotted for Martin Lake and San Miguel lignites in Figure 43. The much higher sticking fraction of the San Miguel may reflect differences in the mode of occurrence of the inorganic constituents in the two lignites. Zeolites have been identified as principal mineral components of San Miguel lignites.22 These zeolites can contain significant quantities of sodium, which can reduce the melting polnt and enhance the formation of very sticky, partially molten particles, resulting in the observed high sticking fraction. In comparison, Martin Lake lignite has a similar range of inorganic constituents to some North Dakota lignites, in which the alkali and alkaline earth elements are associated with the organic portion of the coal.

The removal of ion-exchangeable cations from Center lignite resulted in only a small decrease in deposit weight and no significant difference in the sticking fraction. However, with 


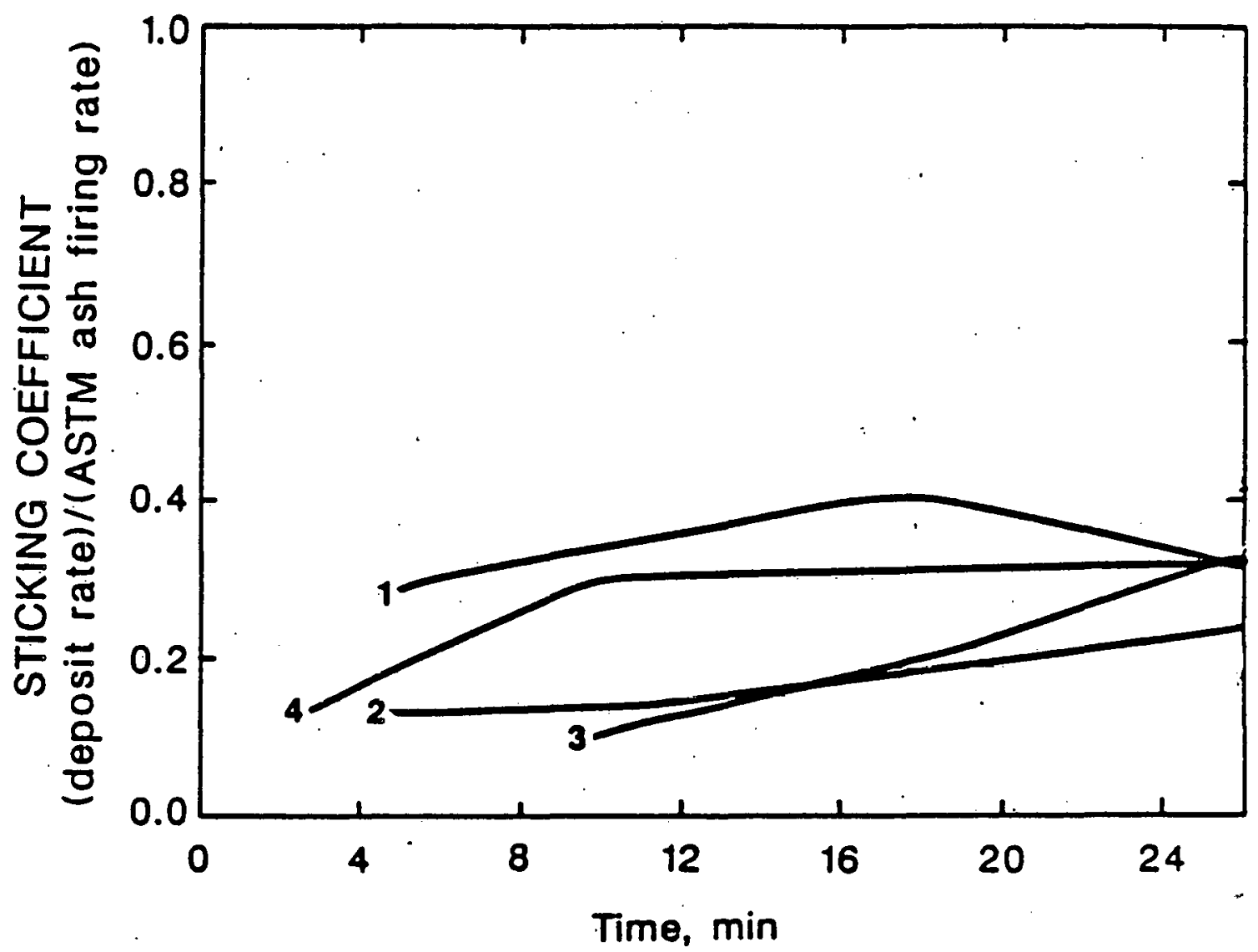

Figure 4 .42. Sticking coefficient versus time for subbituminous coals: coal feed rate $0.2-0.4 \mathrm{~g} / \mathrm{min} ; 20 \%$ excess air; hot zone temperature $=1500^{\circ} \mathrm{C}$; gas temperature at the constrictor $\sim 1260^{\circ} \mathrm{C}$; gas velocity across the substrate $3=4 \mathrm{~m} / \mathrm{sec}$.

( 1 - Rosebud, 2 - Dave Johnston, 3 - Wyodak and 4- Navajo.) 


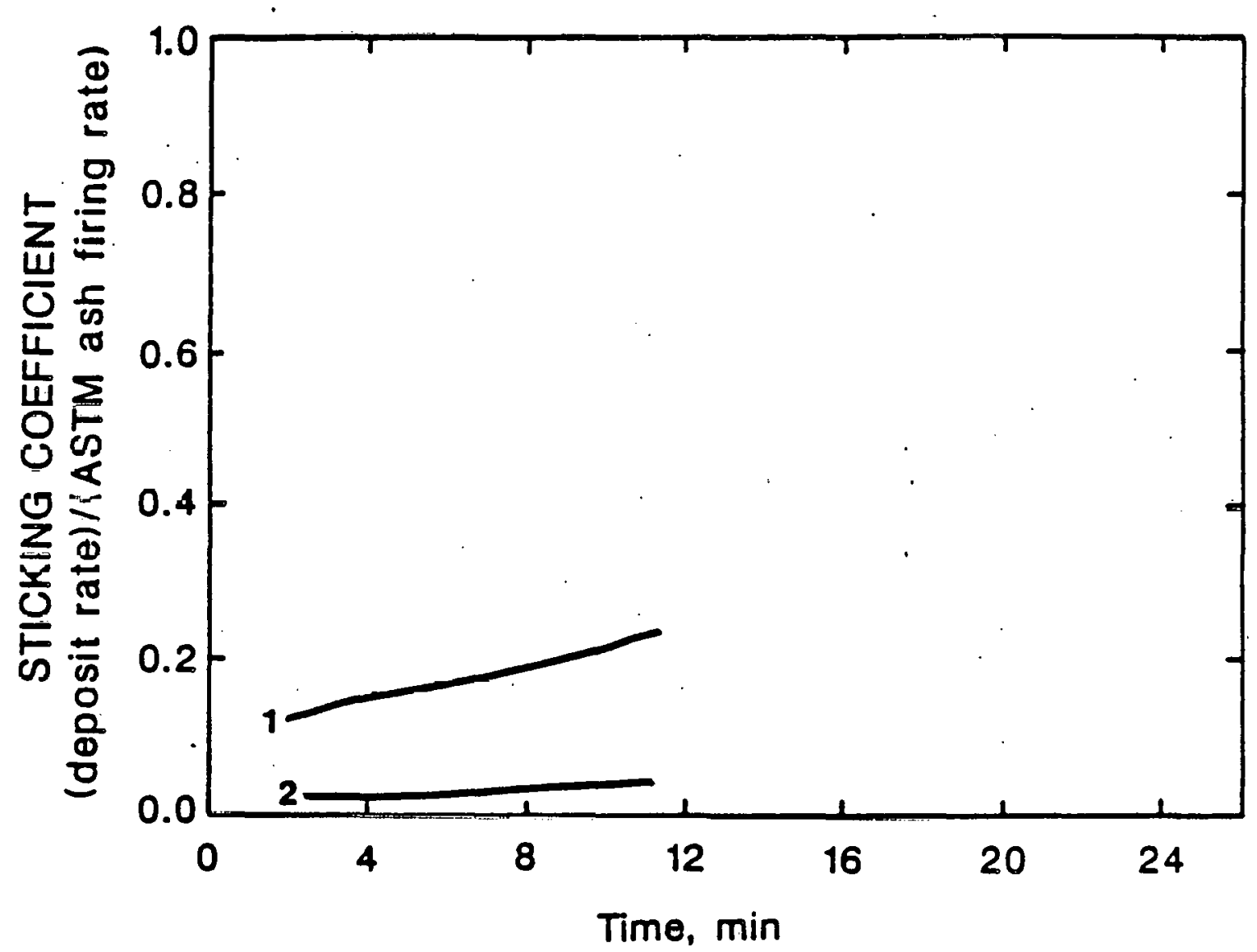

Figure 43.' Sticking coefficient versus time for Texas lignites: coal feed rate $0.2-0.4 \mathrm{~g} / \mathrm{min} ; 15-25 \%$ excess air; hot zone temperature $=1500^{\circ} \mathrm{C}$; gas temperature at constrictor $-1260^{\circ} \mathrm{C}$; gas velocity across substrate 3-4 $\mathrm{m} / \mathrm{sec}$.

(1-Martin Lake and 2 - San Miguel.) 
San Miguel lignite a marked change in sticking fraction was observed in tests with the ion-exchanged sample (Figure 44). The difference in behavior of the ion-exchanged San Miguel and Center lignites may again reflect differences in the association of the inorganic constituents. During combustion in the short residence times of the drop-tube furnace, low melting point species are more likely to form if the alkali is already in direct contact with the aluminosilicate minerals. This is the case with the zeolite minerals in San Miguel lignite. On the other hand, interaction of alkali with aluminosilicates may be less likely in the case of Center lignite because of volatilization of some of the organically bound alkali.

For Rosebud subbituminous coal and its various float/sink fractions, the $1.6 \mathrm{~s} . \mathrm{g}$. sink fraction had the highest sticking fraction. This fraction contains considerable quantities of iron, which result in the formation of sticky, high density particles. The sticking fraction for the $1.4 \mathrm{~s} . \mathrm{g}$. float was almost as high; this fraction contains the highest quantities of alkali and alkaline earth elements, which are likely to react with silicates to form very sticky particles.

Development of Deposit Strength by Sintering

An apparatus was developed to measure strength of deposits. The apparatus is shown in Figure 45. The primary components are a miniature pressure transducer and a miniature horizontal 


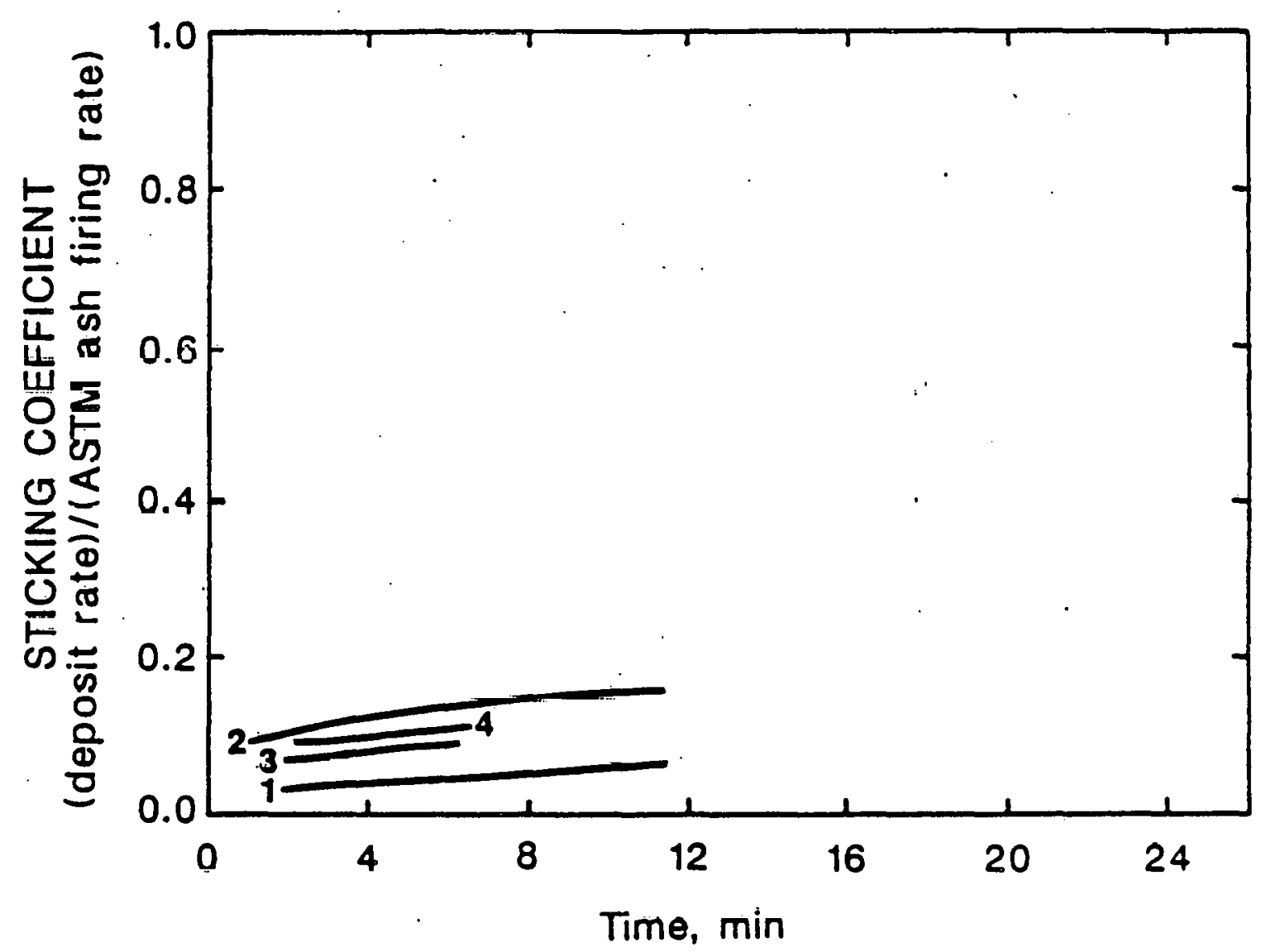

Figure 44. Sticking coefficient versus time for San Miguel and ion-exchanged San Miguel: coal feed rate $0.2-0.4 \mathrm{~g} / \mathrm{min}$; $20 \%$ excess air; hot zone temperatures $=1400$ and $1500^{\circ} \mathrm{C}$; gas temperature at the constrictor $\sim 1260^{\circ} \mathrm{C}$; gas velocity across the substrate $3-4 \mathrm{~m} / \mathrm{sec}$.

( L- San Miguel $1400^{\circ} \mathrm{C}, 2$ - San Miguel $1500^{\circ} \mathrm{C}$, 3: - Lon-exchanged San Miguel. $1400^{\circ} \mathrm{C}, 4$ - ionexchanged San Miguel $1500^{\circ} \mathrm{C}$.) 


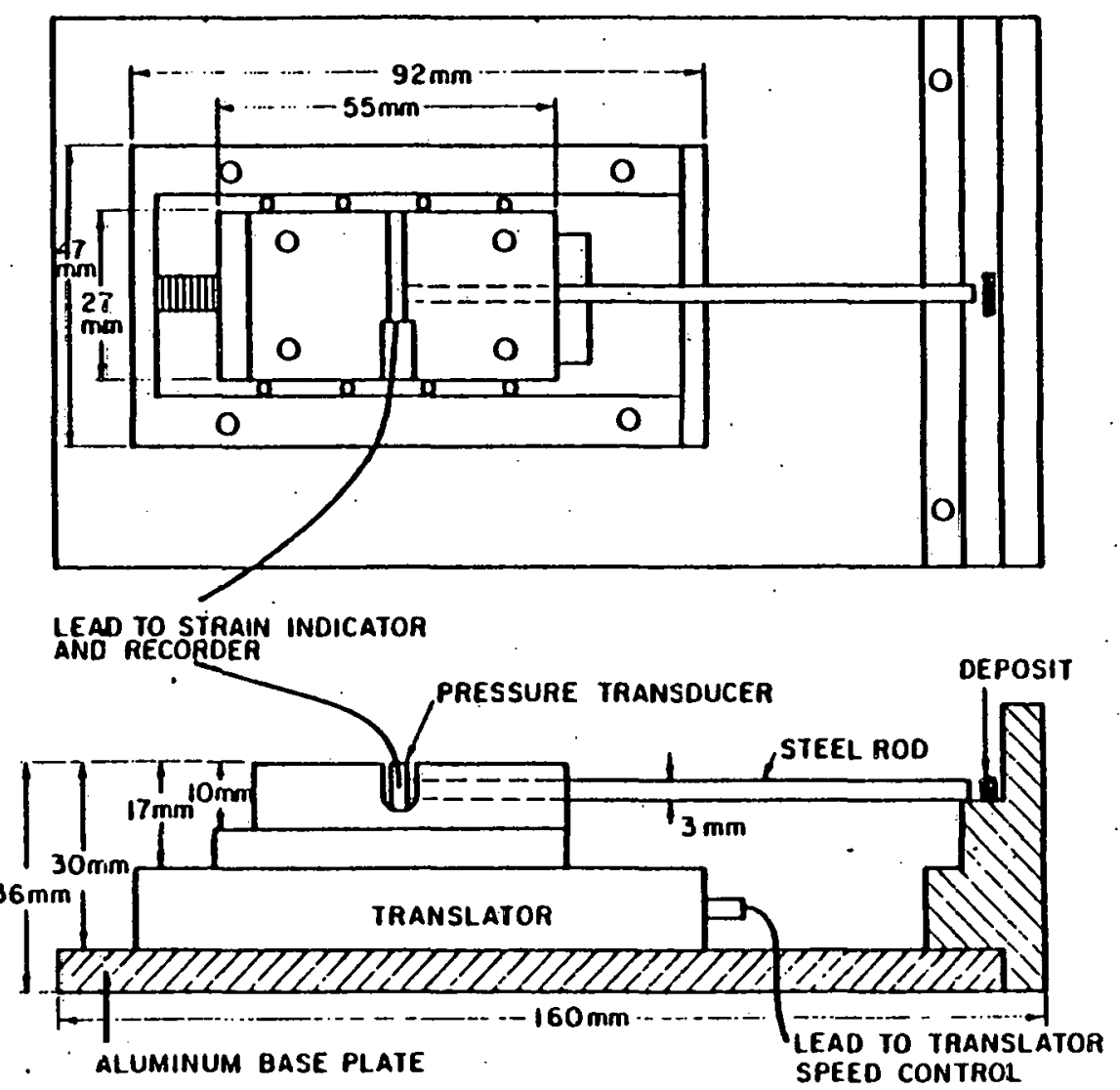

Figure 45. Translator/transducer assembly with deposit strength measuring device. 
translator. The translator has a range of travel of $25 \mathrm{~mm}$ a resolution of 0.02 micrometer, and a maximum speed of $15 \mathrm{~mm} / \mathrm{min}$. The pressure transducer is a diaphragm strain gauge with one active sensing face. The output of the transducer is attached to a strain indicator. The transducer was mounted in a machined aluminum block attached to the horizontal translator. A hole drilled in the block allows the end of a $3 \mathrm{~mm}$ steel rod to make contact with the sensing face of the transducer. The strength of deposits can be determined by compressing the deposit between the end of the steel rod and the aluminum block attached to the base plate. The translator is set in motion and the pressure exerted to crush the deposit is measured.. Measurements can be made at 3$6 \mathrm{~mm}$ intervals across the deposit.

Deposit strengths were measured for deposits produced from all Suite 2 coals tested except for Navajo, for which the deposit strength was below the detectable limits of the device. The maximum linit of the pressure transdues was $7 \mathrm{MPa}$; some deposit strengths exceeded this upper limit. Strengths were measured at selected intervals. $(3-6 \mathrm{~mm})$ from the base to the top of the deposit. Strengths for some North Dakota lignite ash deposits are shown in Figures 46 and 47 . Deposit strengths for the subbituminous ooals are plotted as a funotion of helght in Figure 48 .

The Wyodak and Dave Johnston coals have very similar ash compositions, yet produce deposits of quite different strengths. 


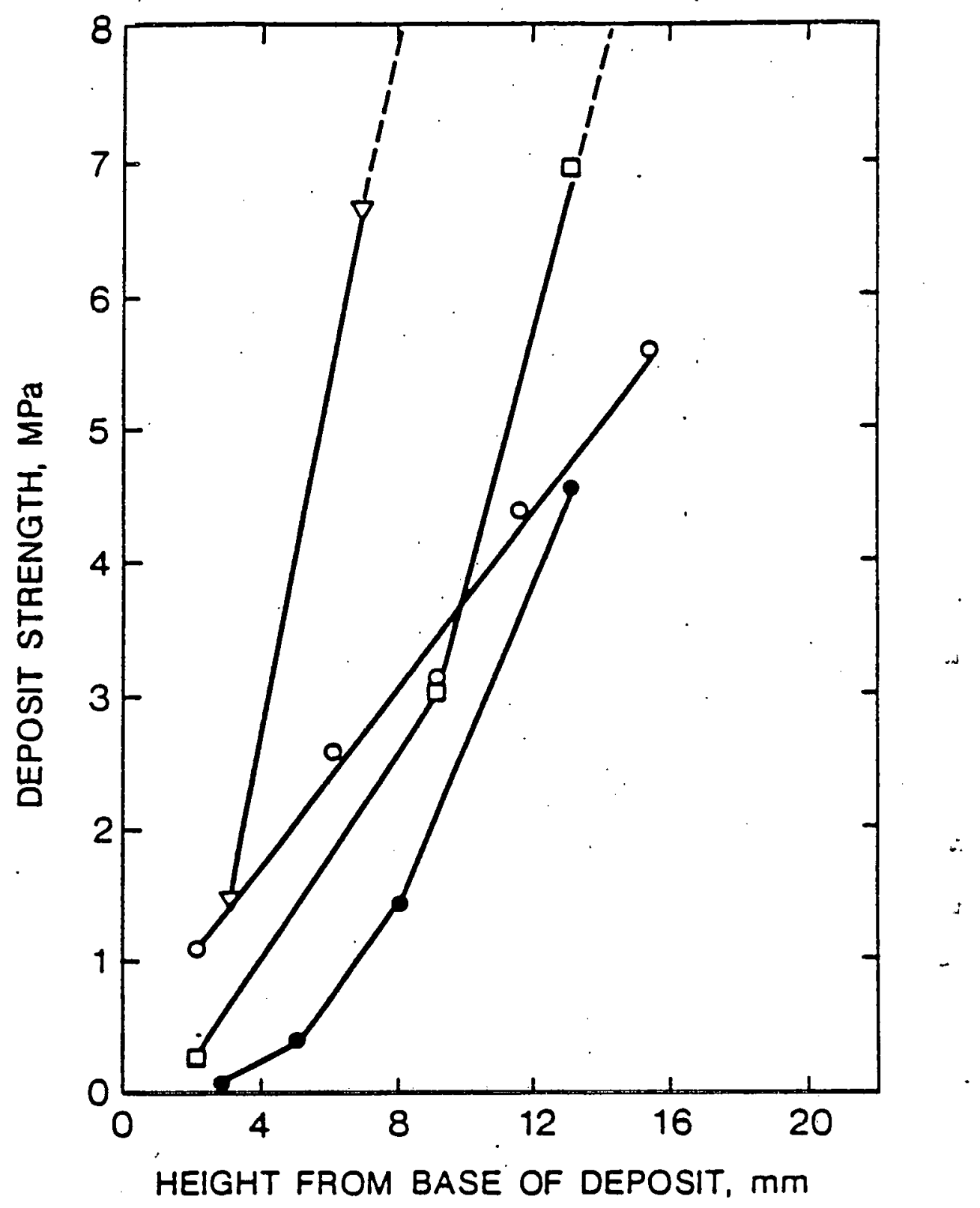

Figure 46. Deposit strength versus deposit height for North Dakota lignite deposits produced at a hot zone temperature of $1500^{\circ} \mathrm{C}$ and a constrictor gas temperature of approximately $1260^{\circ} \mathrm{C}$.

(O - Beulah, - Velva, $\square$ - Indian Head, and $\nabla$ - Center.) 


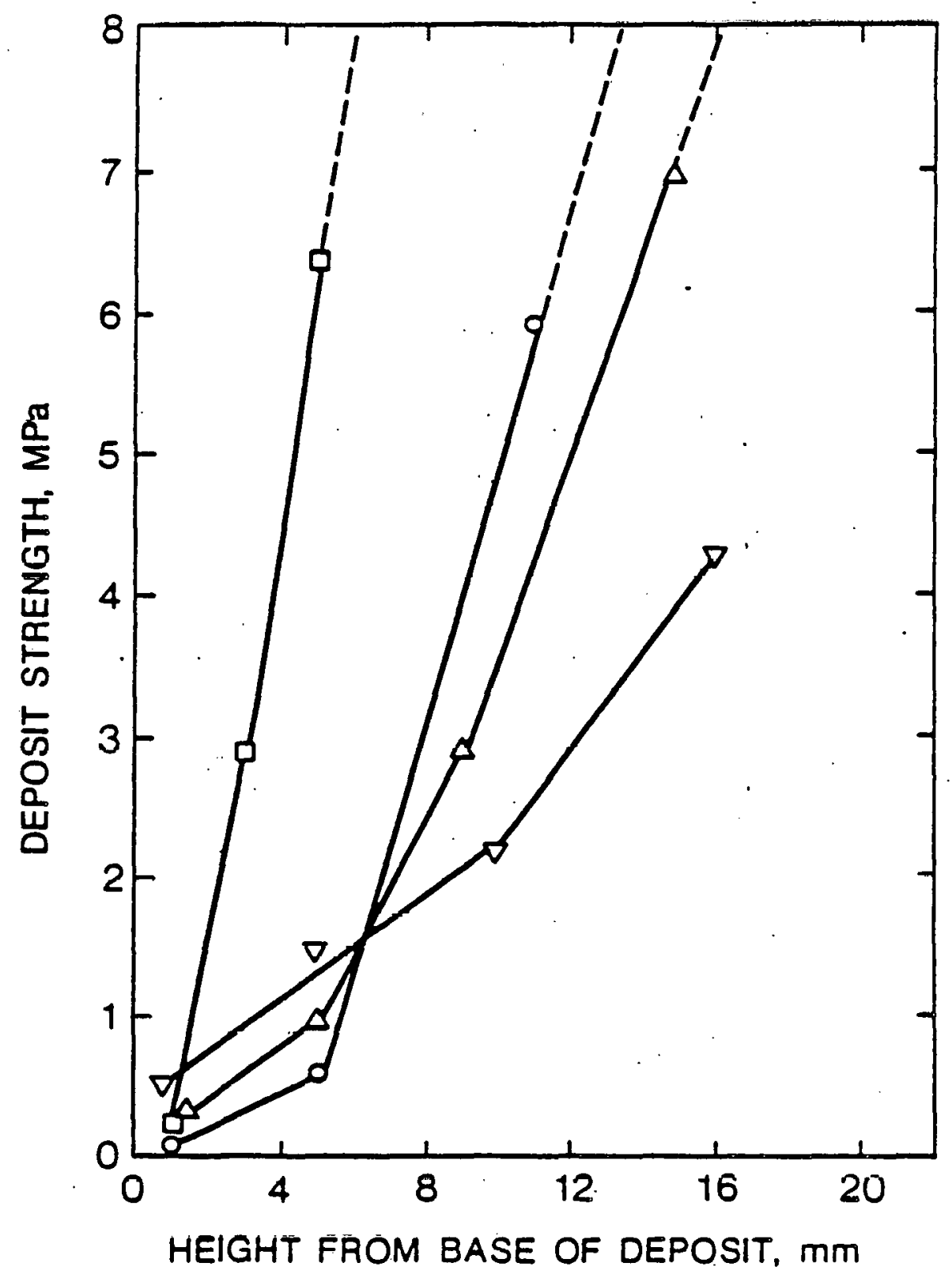

Figure 47. Deposit strength versus deposit height for Gascoyne North Dakota lignite deposits produced at a hot zone cemperature of $1500^{\circ} \mathrm{C}$ and gas temperature at the constrictor of approximately $1260^{\circ} \mathrm{C}$.

( $\square$ - Gascoyne Blue, $\Delta$ - Gascoyne White, $\nabla$ - Gascoyne Red, and O - Gascoyne Yellow.) 


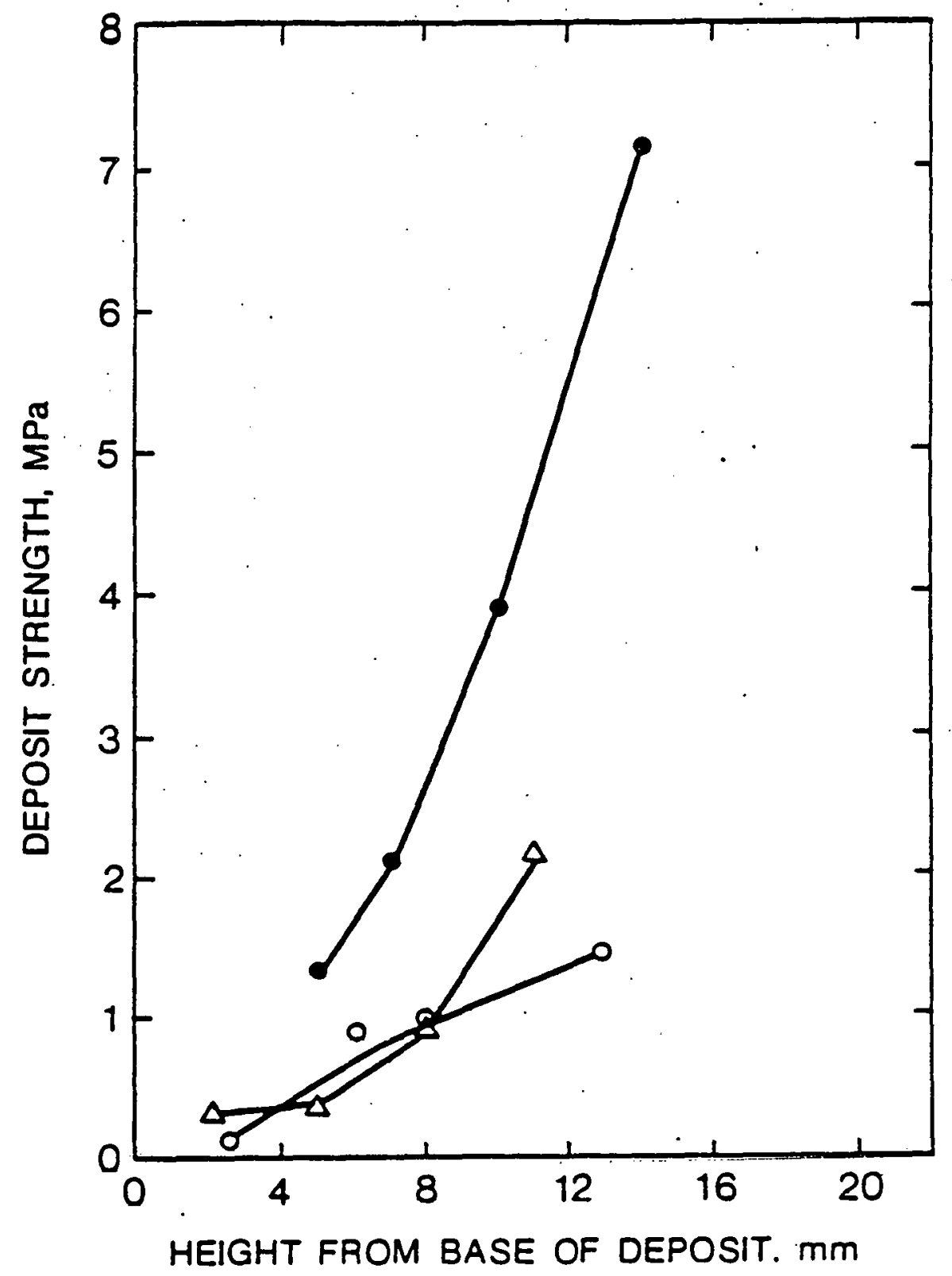

Figure 48. Deposit strength versus deposit height for subbituminous coal deposits produced at a hot zone temperature of $1500^{\circ} \mathrm{C}$ and a constrictor gas temperature of approximately $1260^{\circ} \mathrm{C}$.

(O - Dave Johnston, - Wyodak, and $\Delta$ - Rosebud.) 
The Wyodak ash contains less silica than the Dave Johnston ash. This observation suggests that the principal silicon-containing minerals present in Wyodak are clays, or at least different types of clays than are found in the Dave Johnston coal. The significance of this difference is that clay minerals appear to become completely melted during combustion whereas quartz may not melt or react completely. The quartz content of a coal can be estimated from the equation

$$
\left(\mathrm{SiO}_{2}\right)_{\mathrm{q}}=\left(\mathrm{SiO}_{2}\right)_{1}-1.5\left(\mathrm{Al}_{2} \mathrm{O}_{3}\right)
$$

The subscripts $q$ and $\tau$ represent quarlz dud total silica, respectively. This equation is based on data for British bituminous coals which indicates that the clay minerals have an average alumina/silica weight ratio of 1.5 .23 Thus the term $1.5\left(\mathrm{Al}_{2} \mathrm{O}_{3}\right)$ corrects the total silica content for the amount of silice incorporated in clays; the difference being the silica present as quartz. Applying this equation to the Wyodak and Dave Johnston coals shows quartz contents of $2.0 \%$ and $15.1 \%$, respectively. Compared to the Dave Johnston coal, the clay minerals in Wyodak will react much more readily with the available alkali and alkaline earth elements and may form more liquid phase, resulting in increased viscous flow sintering and thus producing a stronger deposit.

Strength measurements for Rosebud and its float/sink fractions are shown in Figure 49. The $1.4 \mathrm{s.g}$. float fraction produced the strongest deposit. The alkali and alkaline earth elements and finely divided clay minerals concentrate in the 


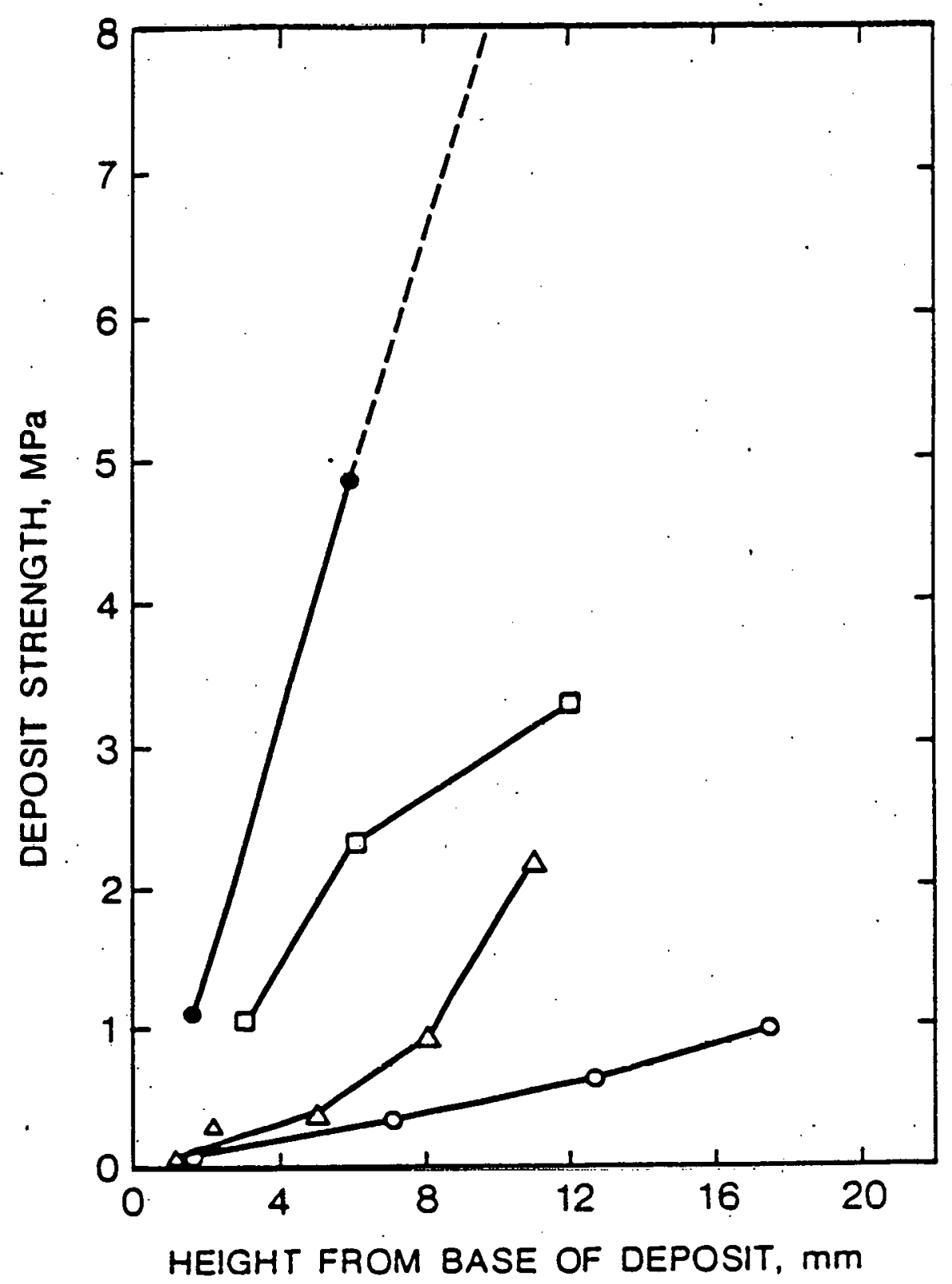

Figure 49. Deposit strength versus deposit height for Rosebud subbituminous coal and float-sink fractions produced with a hot zone temperature of $1500^{\circ} \mathrm{C}$ and a constrictor temperature of approximately $1260^{\circ} \mathrm{C}$. $(O-1.6$ Sink, -1.4 Float., $\square-1.6$ Float, and $\Delta$ - Starting coal.) 
float fraction. The relatively high strength in this deposit is due to the formation of low melting point phases as a result of this association of elements and clay minerals. On the other hand, minerals such as quartz, pjrite, and large agglomerates of clay minerals concentrate in the $1.6 \mathrm{~s} . \mathrm{g}$. sink fraction. The sink fraction produces the weakest deposit because of the low concentration of alkali and alkaline earth elements avalable for reaction with the minerals.

The effeot of removing cations from Genter and sañ Miguel lignites by ion-exchange was to produce deposits weaker than those from the untreated coals. Furthermore, deposits produced in combustion tests with hot zone temperatures of $1500^{\circ} \mathrm{C}$ were stronger than deposits from tests with hot zone temperatures of $1400^{\circ}$, regardless of whether the coal had been ion-exchanged.

It has long been established that for western coals the tendency for ash deposition is strongly related to the sodium content of the coal.2 The strength of deposits, expressed as MPa/ma, is plotted as a function of sodium content, expreseed as $\mathrm{Na}_{2} \mathrm{O}$ in the ash, in Figure 50. Although there is appreciable scatter in the data, it appears that there is a maximum or levelling off at approximately $8.8 \% \mathrm{Na}_{2} \mathrm{O}$. It is interesting to note that a plot of ash deposition (e.g. as weight of deposit collected on simulated heat exchange tubes in a pilot scale combustor) as a function of sodium also levels off in the region of $8-8.5 \% \mathrm{Na}_{2} \mathrm{O}^{24}$. This comparison suggests a relationship, 


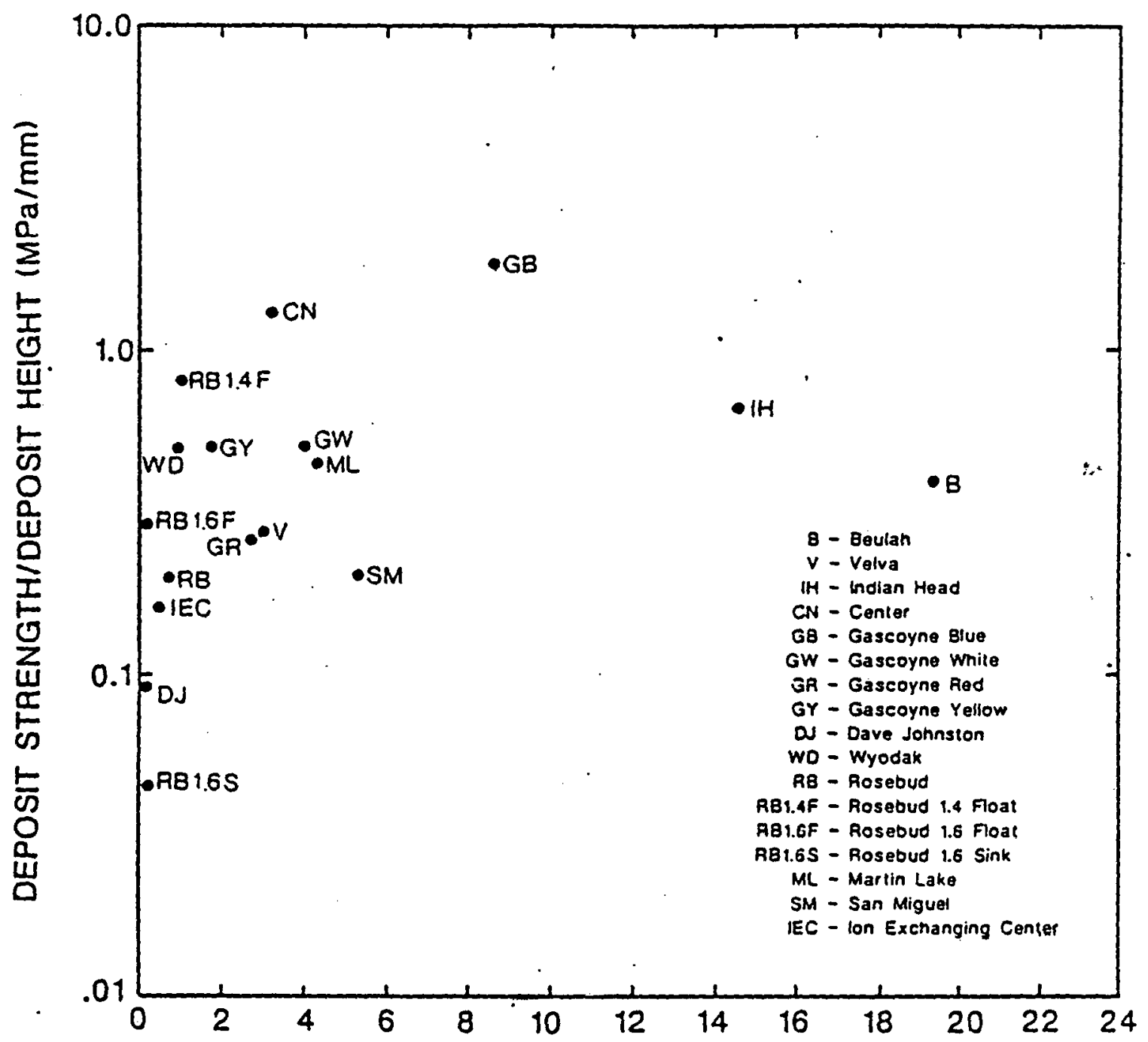

SODIUM OXIDE (wt.\% equivalent oxide)

Figure 50. Deposit strength/deposit height ratio versus sodium content of the ASTM ash (hot zone temperature $=1500^{\circ} \mathrm{C}$, constrictor gas temperature $\left.-1264^{\circ} \mathrm{C}\right)$. 
albeit still tenuous, between the growth of strength in a deposit and the ability of a large deposit mass to form on tubes.

SEM-EDS analyses were used to examine the microstructure of . polished cross-sections of deposits and to deterine the morphological and compositional changes that occur from the base of the deposit to the top. Backscatter electron imaging was used to distinguish between crystalline and glassy phases present. Analyses of points and areas were performed to determine the composition of the glassy and crystalline phases. A compilation of the microphotographs and extensive tables of the analytical results have been published elsewhere.25 The principal conclusions of this work will be presented here.

The formation of crystalline material appears to be an indication of the degree of interaction between ash-forming species within the ash deposits. Some of the strongest deposits examined contained abundant erystals such as pyroxcnc and melilite. In these strong deposits the sodium concentrates in the glass phase; thus sodium would be expected to reduce the viscosity of the liquid phase, resulting in increased deposit strength.

Deposit strength development is primarily due to viscous flow sintering. The rate of sintering can be determined by the following equation 26

$$
S_{r}=k_{1}\left(R_{E} / c\right)(1 / V)
$$


where $R_{g / c}$ is the ratio of glass to crystalline material and $V$ is the viscosity of the glass. The glass is primarily responsible for viscous flow sintering and thus is responsible for development of deposit strength.

The viscosity of the glass phase was calculated from the composition of the glass determined by SEM-EDS analysis; calculations were done using the modified Urbain equation developed for low-rank coal ash slags." 7 Composition data and calculated viscosities are summarized in Table 43. The maximum strength observed in a deposit is plotted as a function of calculated liquid viscosity in Figure 51. The deposit strength shows an inverse relationship to the viscosity of the glass phase, which is consistent with viscous flow sintering theory.

The partitioning of sodium during combustion to form solid, liquid, and gas phase species is very important with regard to boiler slagging and fouling, especially for the Western coals. The interaction of sodium with sulfur and silicates produces low melting point phases and thereby increases both the stickiness of ash particles and the quantity of low-viscosity liquid available for sintering. Equilibrium calculations were used to predict the variation of sodium-containing species in the gas and liquid phases as a function of temperature. The calculations were performed using the computer program SOLGASMIX, which calculates complex phase equilibria by free energy minimization. 29,29,30 The program has been adapted for use on an IBM-PC computer. 1 
Table 43. Composition and riscosity of glass phase determined by SEM-ELS analysis for lignites.

\begin{tabular}{|c|c|c|c|c|c|c|c|}
\hline Oxide & Beulah & $\begin{array}{l}\text { Gascoyne } \\
\text { Fed }\end{array}$ & $\begin{array}{l}\text { Gascoyne } \\
\text { White }\end{array}$ & $\begin{array}{l}\text { Gascoye } \\
\text { Blue }\end{array}$ & $\begin{array}{l}\text { Gascoyne } \\
\text { Yellow } \\
\end{array}$ & Center & Velra \\
\hline $\mathrm{SiO}_{2}$ & 47.2 & 55.1 & 59.7 & 55.7 & 50.4 & 43.9 & 46.9 \\
\hline $\mathrm{Al}_{2} \mathrm{O}_{3}$ & 16.8 & 9.3 & 10.2 & 10.4 & 14.7 & 17.9 & 15.9 \\
\hline $\mathrm{Fe}_{2} \mathrm{O}_{3}$ & 6.8 & 6.0 & 0.9 & 3.7 & 2.1 & 3.8 & 5.1 \\
\hline $\mathrm{TiO}_{2}$ & 0.7 & 1.9 & 3.1 & 0.7 & 1.3 & 0.3 & 0.7 \\
\hline$P_{2}{ }^{O_{5}}$ & 1.2 & 0.2 & 0.0 & 0.0 & 0.0 & 0.0 & 0.0 \\
\hline $\mathrm{CaO}$ & 16.6 & 20.3 & 16.4 & 17.4 & 20.9 & 20.8 & 25.6 \\
\hline $\mathrm{MgO}$ & 0.2 & 3.9 & 2.5 & 3.3 & 9.4 & 5.8 & 3.9 \\
\hline $\mathrm{Na}_{2} \mathrm{O}$ & 7.2 & I. 1 & 5.3 & 7.5 & 0.4 & 4.2 & 0.7 \\
\hline $\mathrm{K}_{2} \mathrm{O}$ & 0.2 & 0.2 & 0.5 & 0.2 & 0.2 & 0.9 & 0.4 \\
\hline $\mathrm{SO}_{3}$ & 0.2 & 0.3 & 0.2 & 0.2 & 0.2 & 1.0 & 0.2 \\
\hline
\end{tabular}

Viscosity at $1300^{\circ} \mathrm{C}$ $(\mathrm{PaS})$ $80 \quad 154$

123.203

93 
Table 43. Composition and viscosity of glass phase determined by SEli-EDS analysis for subbituminous coals.

\begin{tabular}{|c|c|c|c|}
\hline Oxide & Rosebud & Wyodak & Dave Johnston \\
\hline $\mathrm{SiO}_{2}$ & 77.2 & 50.8 & 51.6 \\
\hline $\mathrm{Al}_{2} \mathrm{O}_{3}$ & 15.4 & 27.5 & 31.9 \\
\hline $\mathrm{Fe}_{2} \mathrm{O}_{3}$ & 2.4 & 1.4 & 1.6 \\
\hline $\mathrm{T} \mathrm{O}_{2}$ & 0.5 & 0.0 & 0.2 \\
\hline $\mathrm{P}_{2} \mathrm{O}_{5}$ & 0.0 & 0.0 & 0.0 \\
\hline $\mathrm{CaO}$ & 2.0 & 18.6 & 12.5 \\
\hline $\mathrm{MgO}$ & 0.6 & 0.4 & 0.7 \\
\hline $\mathrm{Na}_{2} \mathrm{O}$ & 0.3 & 0.6 & 0.2 \\
\hline $\mathrm{x}_{2} \mathrm{O}$ & 1.3 & 0.2 & 1.1 \\
\hline $\mathrm{SO}_{3}$ & 0.0 & 0.2 & 0.0 \\
\hline $\begin{array}{l}\text { Viscosity } \\
\text { at } 1300^{\circ} \mathrm{C} \\
(\mathrm{PaS}) \\
\end{array}$ & 677 & 321 & 500 \\
\hline
\end{tabular}




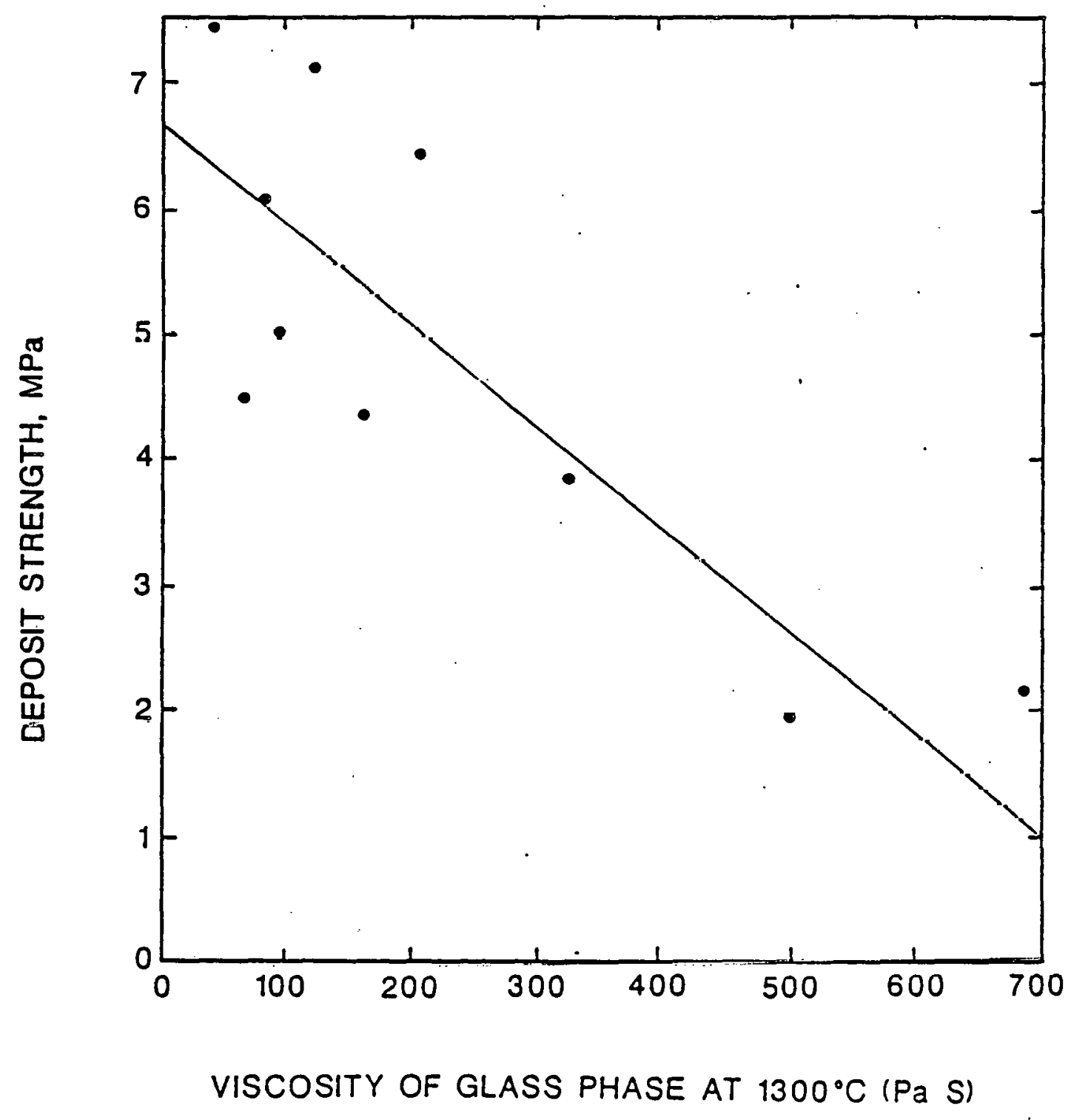

Figure 51. Deposic atrength versus viscosicy of the glass phase for 10 selected lignite and subbituminous coals. 
In a simple case, using only thermodynamic data for compounds of the elements $\mathrm{Na}, \mathrm{Si}, \mathrm{S}, \mathrm{O}, \mathrm{N}, \mathrm{H}$ and $\mathrm{C}$, the major sodium-containing gaseous species were predicted for Gascoyne White lignite. The results are shown in Figure 52 . These results agree well with predictions made by other investigators. 32 The distributions of sodium-containing liquids are shown in Figure 53. The most abundant sodium-containing liquid up to $1340 \mathrm{~K}$ $\left(1067^{\circ} \mathrm{C}\right)$ is $\mathrm{Na}_{2} \mathrm{SO}_{4}$; at higher temperatures $\mathrm{Na}_{2} \mathrm{Si}_{2} \mathrm{O}_{5}$ is the most abundant.

By expanding the thermodynamic data base to include the. elements $\mathrm{Na}, \mathrm{Mg}, \mathrm{Al}, \mathrm{Si}, \mathrm{S}, \mathrm{Ca}, \mathrm{Fe}, \mathrm{O}, \mathrm{N}$, and $\mathrm{H}$, and their compounds the predictions change somewhat. For the gaseous species the only change is a reduction in the amount of $\mathrm{Na}_{2} \mathrm{SO}_{4}$ predicted. However, for the liquid phase $\mathrm{Na}_{2} \mathrm{Si}_{2} \mathrm{O}_{5}$ is no longer predicted to be the most abundant sodium-containing liquid; rather, the most abundant species are predicted to be $\mathrm{NaAlSiO}_{4}$ and NaAlsis $\mathrm{O}_{8}$. The predicted formation of the aluminosilicates rather than silicates suggests that the aluminosilicates form preferentially to the reaction of sodium with silica above 1100 K. At lower temperatures $\mathrm{Na}_{2} \mathrm{SO}_{4}$ becomes the dominant sodiumcontaining liquid phase.

Obviously the relative abundance of the various species predicted by SOLGASMIX will be influenced by the composition of the coal. For example, with Center lignite, which contains higher 


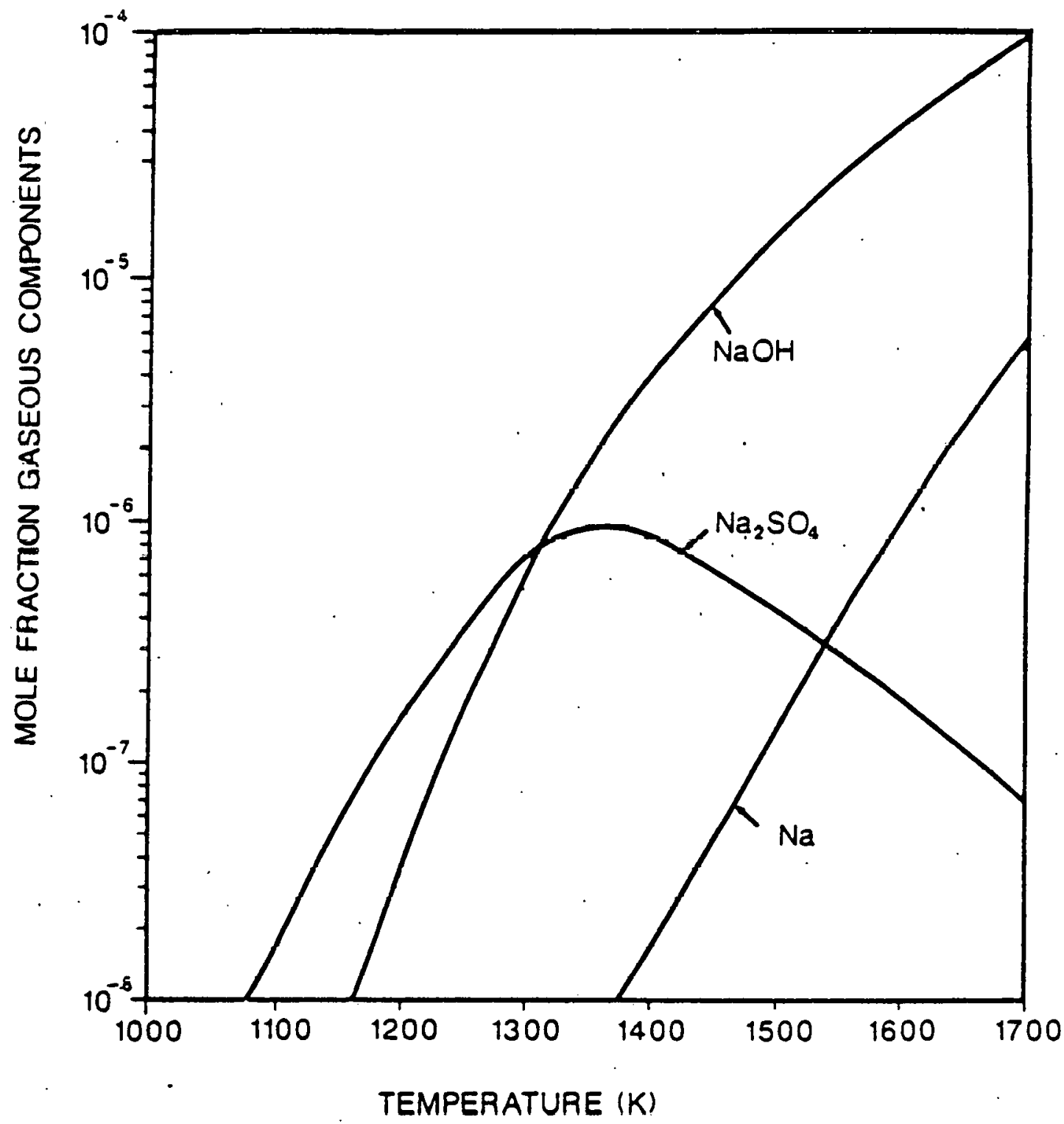

Figure 92. Sodium-concaining gaseous species predicted to form during the combustion of Gascoyne White lignite at $20 \%$ excess air using equilibrium data set Na-Si-S-O-N-S. 


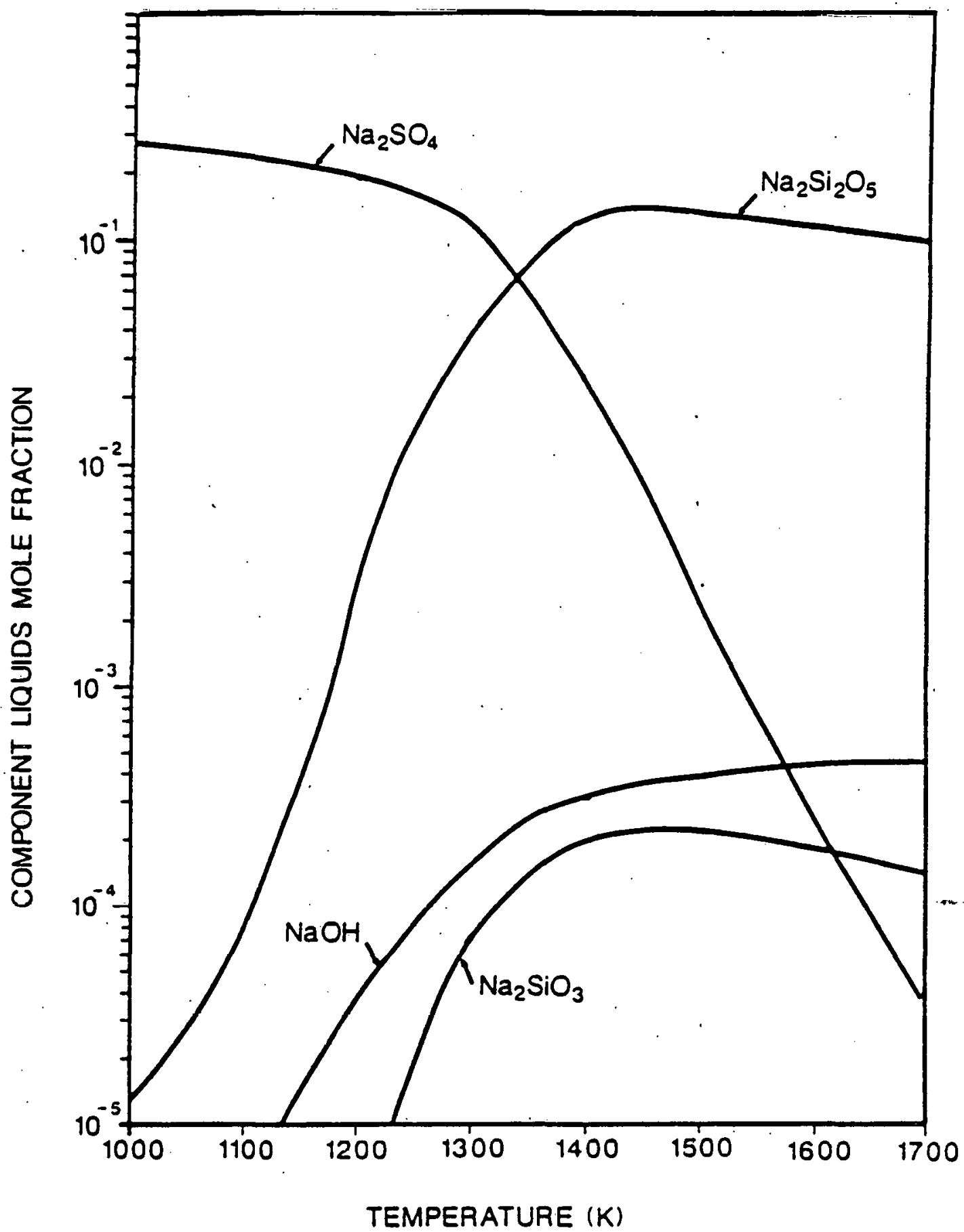

Figure 53. Distribution of sodium-containing liquid species predicted to form during the combustion of Gascoyne White lignite at $20 \%$ excess air. Predicted using equilibrium data set $\mathrm{Na}-\mathrm{Si}-\mathrm{S}-\mathrm{O}-\mathrm{N}-\mathrm{C}$. 
concentrations of the alkali and alkaline earth elements and lower amounts of silicon than the Gascoyne white, high concentrations of $\mathrm{Na}_{2} \mathrm{SO}_{4}$ were predicted up to nearls $1700 \mathrm{~K}$ $\left(1427^{\circ} \mathrm{C}\right)$. Such silicates and aluminosilicates as $\mathrm{NaAlSi}_{3} \mathrm{O}_{8}$, $\mathrm{NaAlSi}_{2} \mathrm{O}_{6}$, and $\mathrm{Na}_{2} \mathrm{Si}_{2} \mathrm{O}_{5}$ are present in mole fractions less than $10^{-5}$

The influence of sodium on the stability of the major species formed during combustion of Gascoyne. Yellow lignite was modeled by running a series of SOLGASMIX calculations in which the input value of the $\mathrm{Na}_{2} \mathrm{O}$ content of the ash was increased by 1.5 wt.\% for each successive calculation. The major liquid species predicted to form at $1600 \mathrm{~K}$ are plotted as a function of sodium content in Figure 54. As the concentration of sodium is increased the predicted amount of sodium-containing silicates Pirst increases, then passes through a broäd maximum and eventually declines. With respect to the solid phases, the mole fraction of gehlenite, $\mathrm{Ca}_{2} \mathrm{Al}_{2} \mathrm{SiO}_{7}$, increases with increasing sodium content, while akermanite, $\mathrm{Ca}_{2} \mathrm{MgSi}_{2} \mathrm{O}_{7}$, remains essentially constant. Unfortunately, thermodynamic data for sodamelilite could not be found; the inclusion of this species in the calculations could have an influence on the predicted abundances and relative stabilities of the other solid and liquid phases.

The quantity and composition of the liquid phase produced during combustion of the suite 2 coals was predicted for those coals for which SEM-EDS characterization had been performed on 


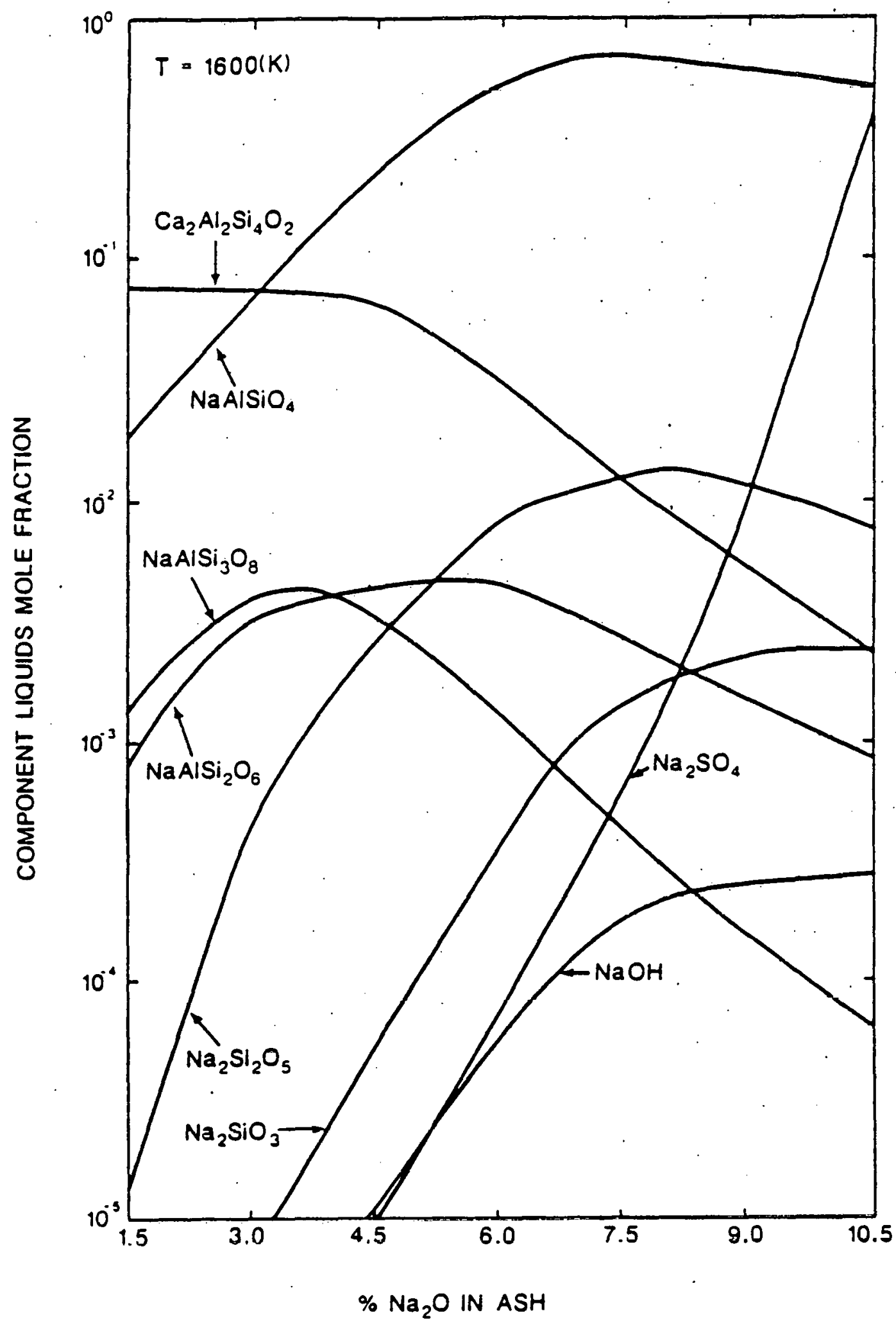

Figure 54. Influence of sodium content on the distribution of liquid species predicted to form upon combustion of Gascoyne Yellow coal using equilibrium data set $\mathrm{Na}-\mathrm{Mg}-\mathrm{Al}-\mathrm{Si}-\mathrm{S}-\mathrm{Ca}-\mathrm{Fe}-\mathrm{O}-\mathrm{N}$. 
the deposit cross-sections. The composition of the liquid phase was determined by normalizing the sum of the mole fractions of each of the major constituents to 100\%. Reasonably good preliminary predictions of the composition of the liquid phase, as compared to actual SEM-EDS analysis, could be made for coals with ashes having base-to-acid ratios less than 1.2. Problems with the calculations were encountered for coals of greater than 1.2 base-to-acid ratio in the ash and for coals having high concentrations of calcium. The deposit strength is plotted as a funclion of the predicled quastity of liquid in Figure 50. Deposit strength increases with increasing quantity of liquid phase. 


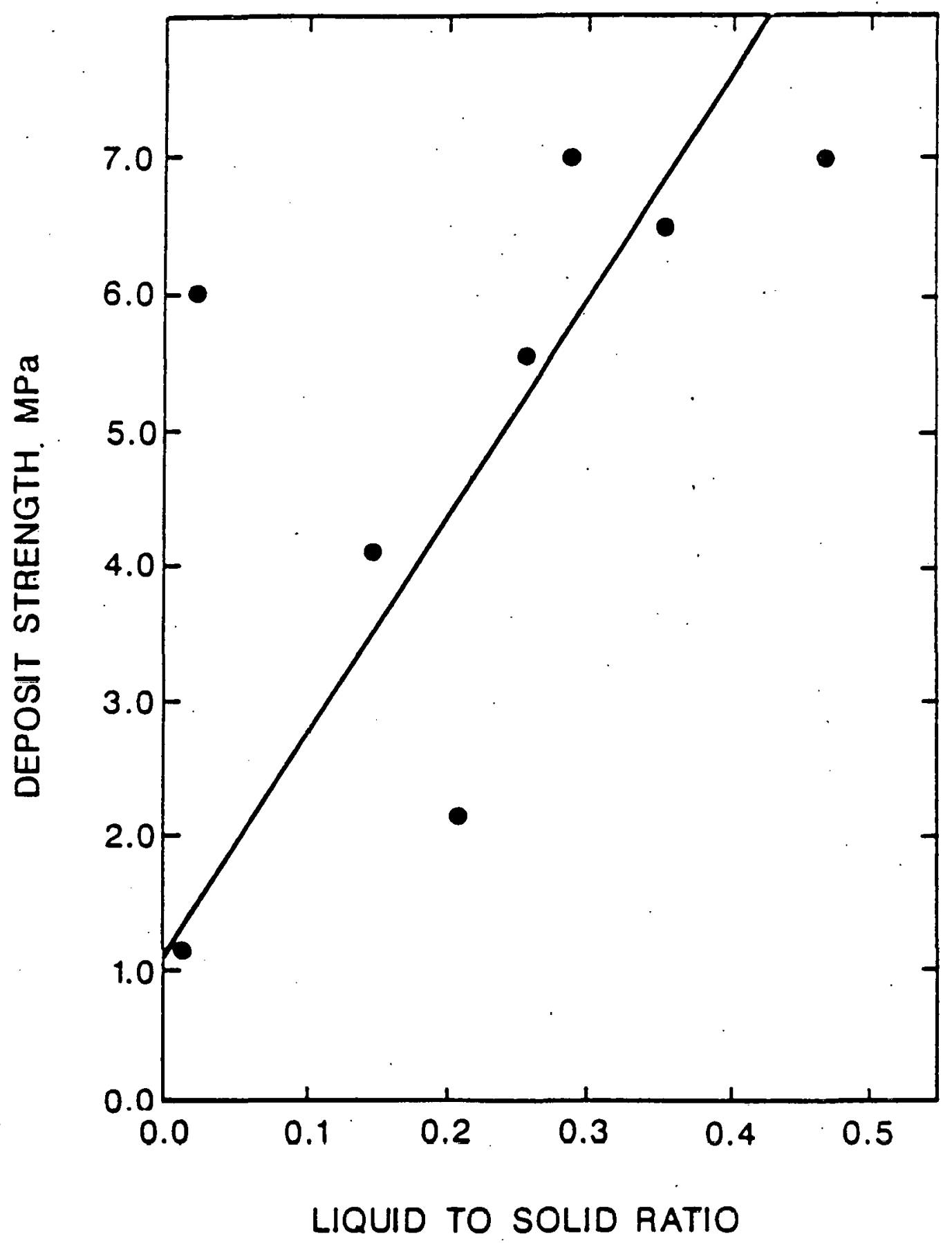

Figure 55. Deposit strength versus predicted quantity of liquid in deposics $\left(1300^{\circ} \mathrm{C}\right)$. 


\section{CONCLUSION}

Ash particles and the gaseous products of combustion are accelerated to about $3-4 \mathrm{~m} / \mathrm{sec}$ and impinged on a water-cooled oxidized boiler steel substrate held at $500 \circ \mathrm{C}$. The gas stream undergoes a sharp change in direction upon encountering the substrate. This change creates a higher gas velocity in the dircetion of tho inooming hot gases toward the centier nf the - substrate compared to that flowing around the substrate. A deposit begins to form due to the impingement of particles and flue gas on the substrate. The principal mechanism of particle transport to the surface of the substrate is by inertial impaction, as indicated by the average size of ash particles in the deposit being much larger than the particles in the dust around the deposit mass. Many particles may impact and rebound, but some will stick to the surface of the steel and form a strong bond with the oxide layer. These strongly bonded parlicles are thought to be characteristic of those that cannot be removed by conventional soot-blowing techniques from full-scale utility boiler water walls. The ability of these particles to stick to the boiler steel surface depends upon the melting behavior, surface tension, and wetting ability of the ash particle, and the nature of the boiler steel surface. The particles that form the strongest bonds are rich in iron and silicon, followed by those rich in iron and sulfur. 
A very thin (less than $1 \mathrm{~mm}$ ) dust layer forms, over the entire surface of the substrate. This layer consists of very small particles possibly transported across the boundary layer due to vapor-phase and small-particle diffusion, thermophoresis, and electrophoretic effects. These particles could be easily removed and were not bonded to the surface. The dust layer is primarily composed of sodium, magnesium, calcium and sulfur. This layer probably continues to form throughout the duration of the test.

The initiation of deposition is by the adherence of molten ash droplets to the oxide layer of the substrate. Upon impinging on the cool substrate, ash droplets solidify rapidly and only a. fraction of the droplets adhere with sufficient strength to the oxide layer. Several small islands of adhered particles may form; this creates more roughness to the surface for further deposition. In shear tests it was frequently found that rather than the particle breaking off the oxide layer, the oxide layer was broken off the substrate. This observation indicates that adherence between the oxide layer and the initial layer of the deposit was stronger than the adherence of oxide layer to the metal. The very weak adhesion of ash drops on a porous reduced steel surface indicates that strong adhesion of ash drops occurs as a result of chemical compatibility between the oxide layer and the ash drop, and is not a result of mechanical anchoring in the microporosity of the steel surface. The strong adherence between the initial layer of ash drops and the oxide layer is probably 
due to a good wetting and a large contact area of the hemispherical droplets on the oxide layer, allowing chemical compatibility at the interface. It also seems likely that the oxide layer on the substrate reduced the rate of heat conduction away from the interface and kept the ash drop less viscous for a longer time, again allowing more chemical compatibility at the interface.

As the deposit grows the temperatures of the deposited material increase, thus increasing the ability of trapping oncoming fly ash particles. The deposit begins to grow from the substrate at the point where the gas stream impinges on the base layer. The dust layer easily separates from the base layer of the deposit. The base layer is lightly sintered due to the higher temperatures encountered when moving away from the substrate. The degree of crystalinity of the base layer is similar to that of the fly ash, which indicates that very little interaction between particles has occurred. To some extent this lower portion of the deposit is insulated by the upper layers of the growing deposit and thus remains only slightly sintered due to the relatively low temperatures in this region. The mechanical strength of the base is lower than that of the upper regions of the deposit. The quantity of base layer formed is dependent on the type of conal being fired. A qualitative relationship suggests that coals which contained large quantities of organically bound alkali and alkaline earth elements and few clay minerals or quartz produced the largest quantity of base layer in the deposit. 
As particles continue to impact the base, the deposit mass grows in the direction of the oncoming gas stream. The higher temperatures produce more melted and fused material which can act as a captive surface to collect particles that impact the surface. The formation of a captive surface drastically increases the growth rates. When the deposit reaches a certain height, the top of the deposit may give virtually complete capture of the fly ash (i.e., sticking fraction = 1). However, as the deposit grows toward the constrictor, the changing of deposit shape alters the flow of gas around the deposit. Consequently, there may be a fraction of the fly ash entering the constrictor that simply passes over the deposit. The rate of deposit growth can be expressed in terms of variation of sticking fraction with time. Most of the bituminous coals tested exhibited an accelerated rate of growth, whereas most of the low-rank coals showed a more uniform rate of deposition. Low-rank coal deposits in which abundant molten material.existed exhibited an accelerated rate of growth.

The variation of sticking fraction with time is distinctive for each coal. It is hypothesized that different coals have different sticking coefficients for the following reasons:

a) The proportion of fly ash particles which are molten or solid but sticky is different for different coals;

b) The size distribution and density of fly ash particles produced from different coals are different; 
c) The physical and chemical characteristics of the deposit mass formed from different coals are different due to differences in the sintering, chemical reaction, and melting behaviors of the particles after deposition.

The temperature gradient in the deposit mass causes the processes of sintering, chemical reaction and melting to occur at different rates at different locations in the deposit. The extent of these processes increases toward the hot top of the deposit. Hence the deposit has a microstructure leading from the slight sintering of the lower layers to the strongly melted top. The lower layers of deposits from bituminous and low-rank coals showed a close similarity in the size, shape, and chemical composition to that of the fly ash. However, a higher amount of glassy phase was observed at the top of the deposits from bituminous coals,. Whereas a higher amount of crystalline phase occurred at the top of the deposits from low-rank coals.

As the deposit grows and is exposed to higher temperatures (i.e., >1000 C) low-viscosity liquids are formed in the deposit. These low-viscosity liquids are responsible for the development of deposit strength due to sintering. The deposits that appeared to eontain the most fused and sintered moterial were the strongest. The strongest deposits produced from Western coals, contained massive fused regions near the top, with abundant crystal growth. The weak deposits characteristically have high porosity, indicating that the degree of sintering and fusing of 
the ash particles was not as extensive.

As the sintering process continues, crystallization of complex aluminosilicates from the melt phase begins. The crystals mainly consist of alkali and alkaline earth aluminosilicates, such as pyroxenes, melilites, and plagioclase. These phases form as a result of the melting and interaction of quartz and clay minerals with the sodium, calcium, and magnesium which were present in the coal as ion-exchangeable cations. In many highly fused deposits these complex phases appeared to nucleate from regions of high iron content. Highly sintered and fused deposits contained abundant alkali and alkaline earth aluminosilicates.

The strongest deposits contain abundant crystalline material and the weaker ones do not. Previous work ${ }^{2} 4$ has suggested that the formation of crystalline phases, particularly melilites, in addition to a high sodium content is the key to understanding ash deposition. It was suggested that sodium melilite may be the problem-causing species. In the present work it was found that in nearly all cases sodium was not concentrated in the crystalline material but rather was concentrated in the glass adjacent to the crystals. This finding suggests that the sodium-containing liquid which causes extensive viscous flow sintering and dissolution of the other ash components is responsible for the development of deposit strength.

The relative amounts of glass and crystalline phases formed 
during sintering is a critical parameter affecting the, strength of the deposit. This was deduced from the sintering test in which a reduction in strength of fly ash from bituminous coal heat treated above $1050^{\circ} \mathrm{C}$ was found to be associated with the * formation of a crystalline phase during sintering. The formation of crystals raises the viscosity of the residual liquid and hence retards the rate of the sintering process. Compounds added to promote the crystallization of the glass in the fly ash from bituminous coals reduce the strength of the sintered product. In addition, sintering of fly ash from bituminous coal after the removal of the glass material also gives a weaker sintered product.

The primary factors involved in the formation of strong deposits appear to be the availability of alkali and alkaline earth elements to act as a flux, and temperature. Tests on coals from which the ion-exchangeable cations had been removed produced deposits weaker than thuse from the untreatcd ooals. Tests on float/sink fractions showed that the fraction containing the highest amount of alkali and alkaline earth elements produced the strongest deposits. Tests performed at a lower hot zone temperature produced weaker deposits. than tests with the same coal at higher temperatures. Gas volocity mag also have an effect. Preliminary results showed that a weaker deposit was formed at low gas velocities.

The development of deposit. strength is primarily due to 
viscous flow sintering with a reactive liquid phase. The liquid phase consists of low-melting alkali and alkaline earth aluminosilicates. Crystallization very likely changes the composition of the melt and the viscosity of the remaining liquid phase. Deposit strengths show an inverse relationship with viscosity consistent with the theory of development of deposit strength.14 The quantity of liquid predicted (by equilibrium thermodynamic calculations) to form at $1300^{\circ} \mathrm{C}$ correlated well with deposit strength.

Since glass material appears to promote viscous flow sintering in the deposit a reduction in viscosity of the glass enhances the sintering. This was illustrated in the sintering of fly ash from bituminous coal in a reducing atmosphere which developed higher strength at lower temperature than comparable tests in air. This behavior is probably due to the iron being reduced to $\mathrm{Fe}^{+2}$, which entered the glassy network to form a lower melting point iron-glass phase, enabling sintering to take place. Synthetic coal containing illite formed a very strong deposit, and is another example to illustrate the importance of a low melting point glass which promotes the viscous flow sintering process at a relatively low temperature. 
1. Abbott, M. F. Ph.D. Dissertation, The Pennsylvania State University, University Park, PA. (1984).

2. Benson; S. A.; Holm, P. L. Ind. Eng. Chem. Prod. Res. and Devel. 24, 145 (1985).

3.Kuczynski, G. C. J. Appl. Phys., 20, 1160 (1949).

4. Kingery, W. T.; Bowen, H. K.; Uhlaman, D. R. Introduction to Ceramics; John Wiley and Sons: New York, 1976.

5. Raask, E. J. Thermal Analysis, 16, 91 (1979).

6. Conn, R. E.; Austin, L. G. Fuel 63, 1664 (1984).

7. Barnhart, D. H/; W111iains, P. C. Trans. AIME, 78, 1229 (1956).

8. Rindt, D. K.; Jones, M. L.; Schobert, H. H. In Fouling and Slagging Resulting from Impurities in Combustion Gases; Bryers, R. W., Ed.; Hemisphere Publishing: Washington, 1983; pp $17-35$.

9. Massa, M. H.; Wilson, J. S. Adv. X-ray Analysis, 20, 85 (1977).

10. Raask, E. Amer. Chem. Soc. Div. Fuel Chem. Preprints, 29(4), $92(1984)$.

11. Honea, F. I. In Fouling and Slagging Resulting from Impurities in Combustion Gases; Bryers, R. W., Ed.; Hemisphere Press: Washington, 1983; pp. 117-141.

12. France, J. E. ; Grimm, U.; Anderson, R. J.; Kovach, J. J. U. S. Dept. of Energy Rept., No. DOE/METC/84-17 (1984).

13. Bryers, R. W.; Walchuk, O. R. Proc. Intl. Symp. on Combustion Diagnostics; Akron, $\mathrm{OH} ; 1983$.

14. Raask, E. Mineral Impurities in Coal Combustion; Hemisphere Publishing Co.: New York, 1985.

15. Levin, E. M.; Robbins, C. R,; McMurdie, H. F. Phase Diagrams for Ceramists; American Ceramics Society: Columbus, $\mathrm{OH}, 1964$.

16. Jones, M. P.; Livingston, W. R.; Warren, G.; Williamson, J. Trans. Inst. Mining and Metall, 94 , C30 (1985).

17. Moza, A. K.; Shoji, K.; Austin, L. G. J. Inst. Energy, 53, $17(1980)$.

18. Moza, A. K.; Austin, L. G. J. Inst. Energy, 52, 412 (1979). 
